
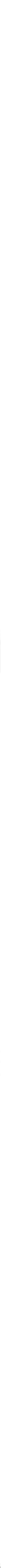


\section{Revista Sistemática}

\section{v.4 n.1 outubro/dezembro 2020}

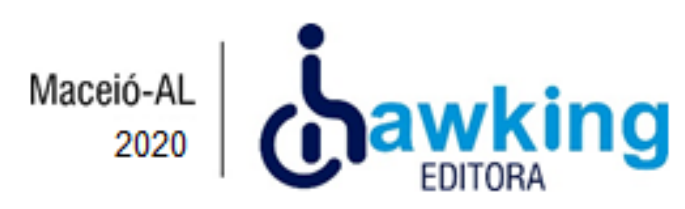


EDITORIAL: Andrea Marques Vandelei Fregadolli

REVISÃO ORTOGRÁFICA: Editora Hawking

DIAGRAMAÇÃO: Luciana de Omena Gusmão e Eduardo Cabral da Silva

DESIGNER DE CAPA: Editora Hawking

IMAGENS DE CAPA: canva.com

ARTE FINAL: Editora Hawking

O padrão ortográfico, o sistema de citações e referências bibliográficas são prerrogativas do autor. Da mesma forma, o conteúdo da obra é de inteira e exclusiva responsabilidade de seu autor.

\section{cc) Creative A Revista Dimensão está sob os direitos da Creative Commons 4.0 (c) Commons https://creativecommons.org/licenses/by/4.0/deed.pt_BR}

\section{NOTAS DO EDITOR}

Para baixar o PDF de cada artigo da Revista Dimensão a partir do seu smartphone ou tablet, escanei o QR code publicado na capa da revista, o qual irá remeter para a página da editora, local onde se encontra a mostra da versão impressa.

Revista Sistemática /Editora Hawking

- Vol 4, n.1 (2020) - Maceió - AL: Editora Hawking, 2020 -

Trimestral

ISSN 2675-5211

1. Revista Sistemática - Periódicos I. Brasil, Editora Hawking

\section{Editora Hawking}

Avenida Fernandes Lima, 2437, Farol. Maceió/Alagoas.

Disponível em: www.editorahawking.com.br

editorahawking@gmail.com 


\section{DIREÇÃO EDITORIAL}

Dra Betijane Soares de Barros

Instituto Multidisciplinar de Alagoas - IMAS

http://lattes.cnpq.br/4622045378974366

\section{CONSELHO EDITORIAL}

\section{Dra ${ }^{\mathrm{a}}$ Adriana de Lima Mendonça}

Graduada em Ciências Biológicas pela Universidade Federal de Alagoas (UFAL, 2001)

Mestre em Química e Biotecnologia pela Universidade Federal de Alagoas (UFAL, 2004)

Doutora em Ciências pela Universidade Federal de Alagoas (UFAL, 2009)

Pós-doutorado em Biotecnologia através do Programa Nacional de Pós Doutorado (PNPD/RENORBIO/CAPES, 2014)

http://lattes.cnpq.br/0381713043828464

\section{Dr. Anderson de Alencar Menezes}

Licenciado em Filosofia pela Universidade Católica de Pernambuco (UNICAP, 1998)

Bacharel em Teologia pelo Centro Unisal - Campus Pio XI (São Paulo) (UNISAL, 2002)

Mestre em Filosofia pela Universidade Federal de Pernambuco (UFPE, 2005)

Doutor em Ciências da Educação pela Universidade do Porto (UPORTO, Portugal, 2009) http://lattes.cnpq.br/3996757440963288

\section{Dra . Andrea Marques Vanderlei Fregadolli}

Bacharel em Farmácia pelo Centro de Ensinos Superiores de Maceió (CESMAC, 1999)

Licenciada em Educação Física pela Universidade Claretiano (CLARETIANO, 2019)

Tecnóloga em Análise e Desenvolvimento de Sistemas pela Universidade Estadual de Ciências da Saúde de Alagoas (UNCISAL, 2015)

Especialista em Nutrição Materno-Infantil pela Unyleya Editora e Cursos S/A, (UNYLEYA, 2017)

Especialista em Psicopedagogia Clínica e Institucional pela Unyleya Editora e Cursos S/A, (UNYLEYA, 2017)

Especialista em Farmácia Clínica Direcionada à Prescrição Farmacêutica pela Unyleya Editora e Cursos S/A, (UNYLEYA, 2017)

Especialista em Análises Clínicas pela Unyleya Editora e Cursos S/A, (UNYLEYA, 2016)

Especialista em Plantas medicinais: manejo, uso e manipulação pela Universidade Federal de Lavras (UFLA, 2001)

Especialista em Farmacologia: Atualizações e Novas Perspectivas pela Universidade Federal de Lavras (UFLA, 2002)

Mestre em Modelagem Computacional de Conhecimento pela Universidade Federal de Alagoas (UFAL, 2011).

Doutora em Ciências pela Universidade Federal de Alagoas (UFAL, 2015).

http://lattes.cnpq.br/5455567894430418

\section{Dr. Eduardo Cabral da Silva}

Graduado em Meteorologia pela Universidade Federal de Alagoas (UFAL, 2006)

Graduado em Matemática pelo Centro de Ensinos Superiores de Maceió (CESMAC, 2015)

Mestre em Meteorologia pela Universidade Federal de Alagoas (UFAL, 2010)

Doutor em Engenharia Civil pela Universidade Federal de Pernambuco (UFPE, 2018)

http://lattes.cnpq.br/2609068900467599 


\section{Dr. Fábio Luiz Fregadolli}

Bacharel em Zootecnia pela Universidade Estadual de Maringá (UEM, 1996)

Mestre em Zootecnia pela Universidade Estadual de Maringá (UEM, 2000)

Doutor em Zootecnia pela Universidade Estadual Paulista Júlio de Mesquita Filho (UNESP, 2004)

http://lattes.cnpq.br/7986638670904115

\section{Dra . Jamyle Nunes de Souza Ferro}

Bacharel em Farmácia pela Universidade Federal de Alagoas (UFAL, 2009)

Mestre em Ciências da Saúde pela Universidade Federal de Alagoas (UFAL, 2012)

Doutora em Ciências da Saúde pela Universidade Federal de Alagoas (UFAL, 2016)

Pós-doutorado pela Universidade Federal de Pernambuco (UFPE, 2018)

http://lattes.cnpq.br/2744379257791926

\section{Dra . Laís Agra da Costa}

Graduada em Ciências Biológicas na Universidade Federal de Alagoas (UFAL, 2011)

Mestre em Ciências da Saúde pela Universidade Federal de Alagoas (UFAL, 2014)

Doutora em Ciências Biológicas (Biofísica) pela Universidade Federal do Rio de Janeiro (UFRJ, 2018)

http://lattes.cnpq.br/2066151967059720

\section{Dr. Patrocínio Solon Freire}

Graduado em Filosofia pela Universidade Católica de Pernambuco (UNICAP, 2000)

Bacharel em Teologia pela Universidade Pontifícia Salesiana (UPS- Itália, 2004)

Especialista em Comunicação Social pela Pontifícia Universidade Católica de São Paulo (PUCSP, 2004)

Especialista em Gestão Educacional pela Faculdades Integradas Olga Mettig (FAMETTIG, 2006)

Mestre em Educação pela Universidade Federal de Pernambuco (UFPE, 2009)

Doutor em Educação pela Universidade Federal de Pernambuco (UFPE, 2014)

http://lattes.cnpq.br/5634998915570816

\section{Dr. Rafael Vital dos Santos}

Licenciado em Ciências Biológicas pela Universidade Federal de Alagoas (UFAL, 2006)

Bacharel em Ciências Biológicas pela Universidade Federal de Alagoas (UFAL, 2010)

Especialista em Diagnóstico Molecular pela Faculdade Pernambucana de Saúde (FPS, 2014)

Mestre em Ciências da Saúde pela Universidade Federal de Alagoas (UFAL, 2010)

Doutor em Materiais pela Universidade Federal de Alagoas (UFAL, 2014)

http://lattes.cnpq.br/3000684462222111 


\section{AVALIADORES DESTE NÚMERO}

Dr $^{\mathrm{a}}$. Andrea Marques Vanderlei Fregadolli

http://lattes.cnpq.br/5455567894430418

Dr. Eduardo Cabral da Silva

http://lattes.cnpq.br/2609068900467599

Dr. Fábio Luiz Fregadolli

http://lattes.cnpq.br/7986638670904115

Dra . Laís Agra da Costa

http://lattes.cnpq.br/2066151967059720

Dra . Lucy Vieira da Silva Lima

http://lattes.cnpq.br/0010369315381653

Dr. Rafael Vital dos Santos

http://lattes.cnpq.br/3000684462222111 


\section{SUMÁRIO}

$\begin{array}{lc}\text { EDITORIAL } & 8\end{array}$

Andrea Marques Vanderlei Fregadolli

CURRÍCULO MULTICULTURAL: DESAFIOS E PERSPECTIVAS PARA A SUA CONSTRUÇÃO E EFETIVAÇÃO

Márcia Lucia Costa da Silva $\quad 11$

Andrea Marques Vanderlei Fregadolli 11

Betijane Soares de Barros $\quad 11$

Marta Lucia Silva Costa 11

O YOUTUBE COMO FONTE DE PESQUISA NA ATUAÇÃO DO PSICÓLOGO ESCOLAR FRENTE AS METAMORFOSES NO ENSINO SUPERIOR 48

Eliane Reis Neves da Silva $\quad 48$

$\begin{array}{ll}\text { Andrea Marques Vanderlei Fregadolli } & 48\end{array}$

$\begin{array}{ll}\text { Betijane Soares de Barros } & 48\end{array}$

Maria José Soares Ribeiro $\quad 48$

Maria Isabel da Silva Martins $\quad 48$

$\begin{array}{ll}\text { Luciano Canuto Jacinto } & 48\end{array}$

O LÚDICO NA EDUCAÇÃO INDÍGENA

$\begin{array}{ll}\text { Marta Lúcia Silva Costa } & 78\end{array}$

$\begin{array}{ll}\text { Andrea Marques Vanderlei Fregadolli } & 78\end{array}$

$\begin{array}{ll}\text { Betijane Soares de Barros } & 78\end{array}$

Marcia Lucia Costa da Silva $\quad 78$

ANÁLISE DOS SISTEMAS DE ESGOTAMENTO SANITÁRIO ÚNICO E SEPARADOR $\quad 114$

Flávio Júnior Bezerra $\quad 114$

Gabryell Henrique Amancio da Silva $\quad 114$

Igor Bruno do Nascimento Santos $\quad 114$

Ivis Kally Pereira Patriota $\quad 114$

Letícia Karen Pereira Martin $\quad 114$

Eduardo Cabral da Silva $\quad 114$

A INFLUÊNCIA DA RELAÇÃO ENTRE SANEAMENTO BÁSICO E SAÚDE PÚBLICA NO COMBATE Â DISSEMINAÇÃO DO COVID-19 134

Marcelo Lucas Alves $\quad 134$

Maria Clara da Rocha dos Santos Silva $\quad 134$

Maria Eduarda Melo Calado $\quad 134$ 
Matheus Henrique Alves da Silva 134

Nívea Tavares da Silva 134

Paulo Bruno Silva Santos $\quad 134$

OTIMIZAÇÃO EM REDES DE DISTRIBUIÇÃO HIDRÁULICAS 153

Ana Gabrielly Morais Silva $\quad 153$

Andreza Leticia da Silva Santos Torres $\quad 153$

Gilvan de Souza Ramos $\quad 153$

João Vinícius Bezerra Lima 153

Michell Araújo de Souza $\quad 153$

Rafaela Ribeiro de Oliveira 153 


\section{EDITORIAL}

\section{Andrea Marques Vanderlei Fregadolli}

A revisão sistemática com ou sem metanálise é uma pesquisa secundária, pois reuni estudos que já foram analisados cientificamente, chamados de primários, para responder uma questão específica de pesquisa. Este tipo de revisão de literatura é planejada e obedece a critérios de inclusão e exclusão. É possível evitar e superar os possíveis vieses que o pesquisador possa ter durante a seleção e análise de um tema, com a aplicação de estratégias científicas por meio desta metodologia (PERISSÉ; GOMES; NOGUEIRA, 2001; GALVÃO; SAWADA; TREVISAN, 2004). Ao reunir resultados de várias pesquisas e descrever os níveis de evidência científica de cada documento avaliado, o leitor perceberá a credibilidade da revisão. A revisão sistemática é abrangente, imparcial e reprodutível. Este processo de revisão de literatura localiza, avalia e sintetiza o conjunto de evidências dos estudos científicos para se obter uma visão ampla e confiável da estimativa do efeito da intervenção (HIGGINS; GREEN, 2009).

A sistematização proporciona a análise crítica quantitativa e/ou qualitativa, esta última permite o desenvolvimento de categorias temáticas e subcategorias, que levam a discussão dos resultados analisados dos documentos científicos, de maneira sintetizada e integrada. A revisão sistemática integrativa é um tipo de revisão de literatura também planejada, mas que integra metodologias diferentes, ou cruzamento de descritores, ou conhecimento empírico com o científico. Pode também integrar opiniões, conceitos ou ideias provenientes das pesquisas analisadas (WHITEMORE; KNAFL, 2005). Na maioria das vezes sua natureza é qualitativa.

As características metodológicas dos trabalhos científicos são classificadas conforme o nível de evidência, segundo a proposta de Melnyk e Fineout-Overholt, em: I - Evidências provenientes da revisão sistemática ou metanálise de dados relevantes, ensaios clínicos randomizados controlados ou oriundas de diretrizes clínicas baseadas em revisões sistemáticas de ensaios clínicos randomizados controlados; II - Evidências derivadas de, pelo menos, um ensaio clínico randomizado controlado bem delineado; III - Evidências obtidas de ensaios clínicos bem delineados sem randomização; IV - Evidências provenientes de estudos de coorte e de casocontrole bem delineados; V - Evidências originárias da revisão sistemática de estudos descritivos e qualitativos; VI - Evidências derivadas de um único estudo descritivo ou qualitativo e VII- Evidências oriundas da opinião de autoridades e/ou relatórios de comitês de especialistas. 
Os resultados das revisões Sistemáticas proporcionam a Prática Baseada em Evidências (PBE). A PBE é um movimento que surgiu para integrar a teoria à prática, com finalidade de reunir, aplicar e avaliar os melhores resultados de pesquisa para uma conduta clínica eficaz, segura e acessível.

A tomada de decisão, na PBE, incorpora a busca da melhor e mais recente evidência, competência clínica do profissional, valores e preferências do paciente ao cuidado prestado (MENDES; SILVEIRA; GALVÃO, 2008), quando aplicada na área da saúde. Observa-se que as revisões sistemáticas, com ou sem metanálise, provenientes de dados relevantes, ensaios clínicos randomizados controlados ou oriundas de diretrizes clínicas baseadas em revisões sistemáticas de ensaios clínicos randomizados controlados estão no topo da evidência. Contudo, todas as áreas do conhecimento podem ser contempladas com o método da revisão sistemática integrativa, pois aproxima o pesquisador da problemática que deseja investigar, traçando um panorama sobre sua produção científica, a fim de conhecer a evolução do tema ao longo do tempo, em diferentes contextos, como também conduzir caminhos para pesquisas futuras (BOTELHO; CUNHA; MACEDO; 2011).

Seguem, a seguir, as seis etapas da revisão sistemática integrativa (WANDERLEY FILHO; FERREIRA, 2019): $1^{\text {a }}$ ) Escolher tema, pergunta norteadora, objetivo geral, estratégias de busca, bancos de terminologias, descritores livres e estruturados, string de busca e bibliotecas virtuais; $2^{\mathrm{a}}$ ) Definir período de coleta dos dados, critérios de inclusão, critérios de exclusão; $3^{\mathrm{a}}$ ) Selecionar o número de trabalhos para revisão sistemática integrativa a partir da leitura dos agentes indexadores das publicações (resumo, palavras-chave e título) e resultados, os quais devem conter os descritores utilizados no estudo; $4^{\mathrm{a}}$ ) Desenvolver categorias temáticas por meio da análise dos trabalhos científicos investigados; $5^{\text {a }}$ ) Analisar, interpretar e discutir os resultados; $6^{\text {a }}$ ) utilizar tecnologias digitais para otimizar o tempo e apresentar a revisão em formato de artigo, o qual contemple propostas para estudos futuros .

Ferramentas oriundas de tecnologias digitais contribuem para o aprimoramento e qualidade das revisões sistemáticas, tais como: bancos de terminologias (DECS, MESH), que possibilitam o uso de descritores codificados para a eficiência do levantamento das publicações científicas; como também as bibliotecas virtuais (Periódicos da CAPES, ScienceDirect, Wiley, PubMed, Mendline, Scopus, Scielo...), que facilitam a acessibilidade aos trabalhos científicos, que estão sendo publicados em todo o mundo. 


\section{REFERÊNCIAS}

BOTELHO, L. L. R.; CUNHA, C. C. DE A.; MACEDO, M. O método da revisão integrativa nos estudos organizacionais. Gestão E Sociedade, v.5, n.11, p.121-136, 2011.

GALVÃO, C. M.; SAWADA, N. O.; TREVIZAN, M. A. Revisão sistemática: recurso que proporciona a incorporação das evidências na prática da enfermagem. Rev. Latinoam. Enferm., v.12, n.3, p.49-56, 2004 Mai-Jun.

HIGGINS, J. P. T.; GREEN, S. (Ed.). Cochrane handbook for systematic reviews of interventions. Version 5.0.2. The Cochrane Collaboration, 2009.

MELNYK, B. M.; FINEOUT-OVERHOL, T. E. Making the case for evidence-based practice. In: Melnyk BM, Fineout-Overholt E. Evidence-based practice in nursing \& healthcare: A guide to best practice. Philadelphia: Lippincot Williams \& Wilkins; p.3-24, 2005.

MENDES, K. D. S; SILVEIRA, R. C. C. P.; GALVÃO, C. M. Revisão integrativa: método de pesquisa para a incorporação de evidências na saúde e na enfermagem. Texto Contexto Enferm. v.17, n.4, p. 758-64, 2008 out-dez.

PERISSÉ, A. R. S., GOMES, M. M., NOGUEIRA, S. A. Revisões sistemáticas (inclusivemetanálises) e diretrizes clínicas. In: GOMES, M. M., organizador. Medicina baseada em evidências: princípios e práticas. Rio de Janeiro (RJ): Reichmann \& Affonso, p.131-48. 2001.

WANDERLEY FILHO, P. A. D.; FERREIRA, A. M. V. Antibióticos nas Fases Iniciais da Vida: Um Precursor da Obesidade Infantil. Revista Portal: Saúde e Sociedade, v.4, n.1, 2019.

WHITTEMORE, R.; KNAFL, K. The integrative review: updated methodology. J Adv Nurs.v.52, n. 5, p. 546-53, 2005. 


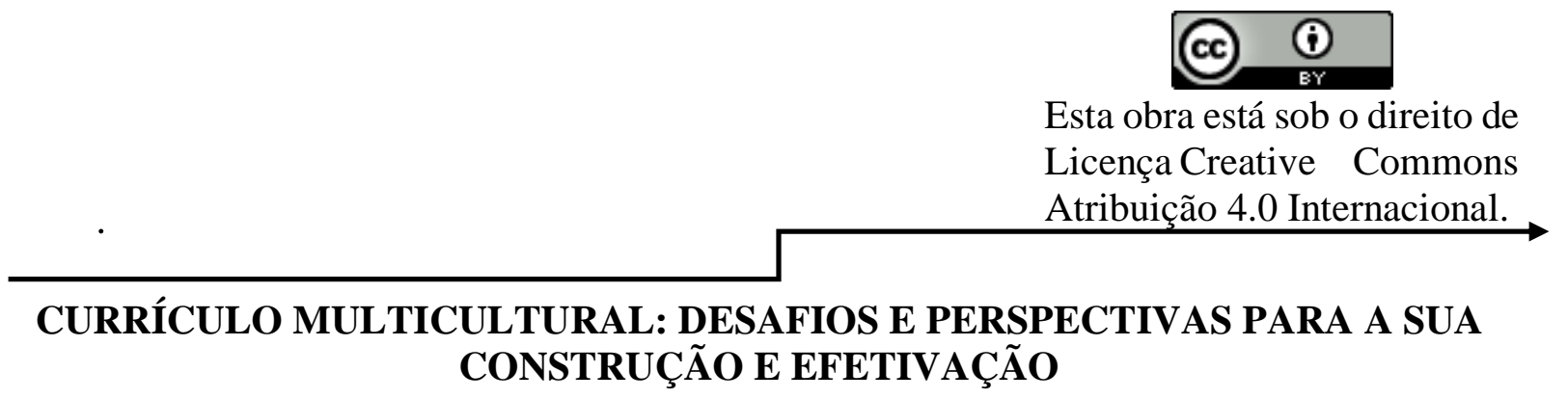

Márcia Lucia Costa da Silva ${ }^{1}$

Andrea Marques Vanderlei Fregadolli ${ }^{2}$

Betijane Soares de Barros ${ }^{3}$

Marta Lucia Silva Costa ${ }^{4}$

\section{RESUMO}

Introdução: Em uma escola inclusiva, há um compromisso com a formação integral de todos os alunos, visando levá-los a uma análise crítica sobre a sociedade em que se insere, criando caminhos para superar as desigualdades sociais e de aprendizagem. Para isso, é importante refletir acerca do modo como as políticas curriculares devem estar organizadas para agregar a ideia de inclusão. Objetivo: analisar a questão multicultural no currículo escolar a fim de compreender as abordagens e perspectivas para os povos indígenas. Metodologia: revisão bibliográfica do tipo sistemática integrativa. Resultados e Discussão: Considerando os critérios de inclusão estabelecidos durante a pesquisa foram selecionados 30 artigos que contemplaram três categorias: a construção de um currículo sob a perspectiva da multiculturalidade; a Lei $\mathrm{n}^{\circ}$ 11.645/2008 e a inserção da temática indígena no currículo escolar; a educação musical inclusiva e o respeito às diferenças: uma possibilidade para o ensino das músicas indígenas. Conclusão: A adaptação curricular sob a perspectiva multicultural não é uma resposta automática à identificação de determinadas necessidades educativas especiais. Trata-se, na verdade, de um processo que deve ser pensado e programado seguindo uma ordem a qual corresponde à organização do trabalho cooperativo baseado no currículo regular.

Descritores: Multiculturalismo. Educação multicultural. Currículo. Currículo multicultural. Educação escolar indígena.
ABSTRACT

\footnotetext{
1 marciamg@live.com

2 deadoutorado@hotmail.com

3 bj-sb@hotmail.com

${ }^{4}$ martaluciadir@gmail.com
}

Introduction: In an inclusive school, there is a commitment to the integral formation of all students, aiming to take them to an analysis and a critical reflection on the society in which they are inserted, creating ways to overcome social and learning inequalities. For this, it is important to reflect on how curriculum policies should be organized to add the idea of inclusion. Objective: to analyze the multicultural issue in the school curriculum in order to understand the approaches and perspectives for indigenous peoples. Methodology: bibliographic review of the integrative systematic type. Results and Discussion: Considering the inclusion criteria established during the research, 30 articles were selected that covered three categories: the 
construction of a curriculum from the perspective of multiculturalism; Law 11,645 / 2008 and the inclusion of indigenous themes in the school curriculum; inclusive music education and respect for differences: a possibility for teaching indigenous music. Conclusion: Curricular adaptation from a multicultural perspective is not an automatic response to the identification of certain special educational needs. It is, in fact, a process that must be thought and programmed following an order which corresponds to the organization of cooperative work based on the regular curriculum.

Descriptors: Multiculturalism; Multicultural education; Curriculum; Multicultural curriculum; Indigenous school education. 


\section{INTRODUÇÃO}

No Brasil, a escola é vista como a instituição que tem a missão de promover a unidade nacional por meio da transmissão de conteúdos unificados, além de valores culturais e morais. O poder público, durante muitos anos viu na educação a força civilizadora fundamental para a construção do consenso na conformação do Estado (CHICARINO, 2017).

As transformações decorrentes do processo de industrialização e desenvolvimento, advindas do crescimento econômico e da consolidação do sistema capitalista, originaram, entre outras mudanças, um acelerado crescimento da escolarização básica, ainda observado atualmente. No entanto, ainda é possível lembrar a ideia de uma escola redentora, a instituição capaz de resolver os grandes dilemas sociais, mas que declina diante do desafio de educar meninos e meninas, homens e mulheres na contemporaneidade (CHICARINO, 2017).

A escola se apresenta como um lugar fundamental de formação e restauração de valores, perdidos ou redefinidos pela modernidade. Mas, assim como o conjunto da sociedade, ela também experimenta e vivencia crises, seja de paradigmas, seja de visão de mundo ou de seu papel social. Nesse panorama de incertezas, sabemos que a educação é um direito, e isso implica que ampliemos a noção de cidadania como direito a ter direito. É nesse sentido que entra o tema da diversidade, o qual é uma realidade desde os tempos mais remotos.

A democratização da sociedade possibilitou a construção de espaços sociais menos excludentes e o convívio na diversidade. Nesse novo cenário, a inclusão social passou a ser uma preocupação de toda a comunidade, de modo que a busca por uma sociedade inclusiva se tornou parte da agenda dos governos.

A escola, como instituição, também sofre pressões para acompanhar essa nova realidade e para lidar com a diversidade do público a que deve atender. A inclusão social, portanto, está diretamente relacionada à necessidade de uma inclusão escolar. Para a concretização desse novo modelo inclusivo, é preciso que o currículo reflita as necessidades diferenciadas de todos os alunos, e não apenas de parte deles (GOMES, 2015).

Em uma escola inclusiva, há um compromisso com a formação integral de todos os alunos, visando levá-los a uma análise e uma reflexão crítica sobre a sociedade em que se insere, criando caminhos para superar as desigualdades sociais e de aprendizagem (GOMES, 2015). 
Para isso, é importante refletir acerca do modo como as políticas curriculares devem estar organizadas para agregar a ideia de inclusão. É preciso apropriar-se do currículo como um instrumento voltado à realização de um projeto educacional dinâmico e sempre comprometido com a diversidade e as singularidades na apropriação do conhecimento por parte dos alunos que integram $\mathrm{o}$ tecido social nas escolas (GOMES, 2015).

Se pensamos o currículo como cultura, destacamos questões referentes ao mundo do trabalho, ao desenvolvimento tecnológico, a atividades desportivas, produção artística, saúde, manifestações sociais e exercício da cidadania, que formam o homem dentro de uma escola que minimamente chamamos de plural, e isso nos leva a compreender o currículo como um conjunto de determinações pedagógicas que se desenvolvem com base em uma intenção educativa; consequentemente, cada escola, na construção do seu currículo, estabelece uma cultura (BERNSTEIN, 2016).

Desse modo, o presente artigo se insere nesse contexto que através de uma revisão bibliográfica do tipo sistemática integrativa, objetiva analisar a questão multicultural no currículo escolar a fim de compreender as abordagens e perspectivas para os povos indígenas. Com isso, compreende-se que ao pensar em um currículo significativo para uma boa escola, é preciso pensar sobre a diversidade cultural e o pluralismo de ideias, entendendo a cultura escolar como uma soma de conteúdos para a elaboração do currículo escolar.

Assim, no que diz respeito ao ambiente escolar, é preciso que se tenha em mente que o processo de ensinoaprendizagem que se importa e valoriza a diversidade deve ponderar sobre as relações sociais estabelecidas na escola e pela constante reflexão sobre as diferenças, a desigualdade social e suas consequências.

A perspectiva multicultural aponta que é possível adotar um currículo que proporcione a todos os alunos as mesmas oportunidades e direitos, independentemente das diferenças sociais, culturais e pessoais. No entanto, um currículo flexível não se constrói deslocado da realidade concreta, mas, sim, dentro de um espaço capaz de favorecer o questionamento, e não apenas a reprodução da ordem vigente (MALANCHEN, 2015).

Assim, a adaptação curricular não é uma resposta automática à identificação de determinadas necessidades educativas especiais. Trata-se, na verdade, de um processo que deve ser pensado e programado seguindo uma ordem a qual 
corresponde à organização do trabalho cooperativo baseado no currículo regular.

\section{METODOLOGIA}

O presente estudo se desenvolveu por meio de uma revisão bibliográfica do tipo sistemática integrativa que adotou as seguintes etapas (detalhadas no quadro 01): $\left.1^{a}\right)$ Definição do tema, seleção da pergunta norteadora e escolha da estratégia de busca, descritores e bases de dados mais eficazes no levantamento das publicações; $2^{\mathrm{a}}$ ) Escolha dos critérios de inclusão e exclusão; $3^{\text {a }}$ ) Identificação dos estudos préselecionados e selecionados através da leitura dos agentes indexadores das publicações, como resumo, palavras-chave e título, bem como organização dos estudos pré-selecionados e identificação dos estudos selecionados; 4a ): Categorização dos estudos selecionados, com elaboração e uso da matriz de síntese, além de análise das informações, formação de uma biblioteca individual e avaliação crítica dos estudos selecionados; $5^{\text {a }}$ ) análise, interpretação e discussão dos resultados; $6^{\text {a }}$ ) Apresentação da revisão em formato de artigo, o qual contemple propostas para estudos futuros (BOTELHO; CUNHA; MACEDO, 2011; SCHMOELLER et al., 2011).

Quadro 1 - Detalhamento das etapas da Revisão Sistemática Integrativa.

\begin{tabular}{|c|c|c|}
\hline ETAPA & TÓPICOS DE CADA ETAPA & DETALHAMENTO DE CADA TÓPICO \\
\hline \multirow[t]{6}{*}{$1^{\mathrm{a}}$} & Tema & $\begin{array}{l}\text { Currículo Multicultural: desafios e perspectivas para a } \\
\text { sua construção e efetivação. }\end{array}$ \\
\hline & Pergunta norteadora & $\begin{array}{l}\text { De que forma a multiculturalidade é articulada no } \\
\text { currículo escolar, com vistas às abordagens e } \\
\text { perspectivas para os povos indígenas? }\end{array}$ \\
\hline & Objetivo geral & $\begin{array}{l}\text { Analisar a questão multicultural no currículo escolar a } \\
\text { fim de compreender as abordagens e perspectivas para } \\
\text { os povos indígenas. }\end{array}$ \\
\hline & Estratégias de busca & $\begin{array}{l}\text { Cruzamento de descritores por meio do operador } \\
\text { boleano AND; Uso de aspas nos politermos (descritor } \\
\text { com mais de um termo) para que a varredura de artigos } \\
\text { científicos contemplasse o termo exato; Uso de filtro } \\
\text { do tipo data de publicação. }\end{array}$ \\
\hline & Descritores livres e estruturados & $\begin{array}{l}\text { Multiculturalismo; Educação multicultural; Currículo; } \\
\text { Currículo multicultural; Educação escolar indígena. }\end{array}$ \\
\hline & Bibliotecas Virtuais & $\begin{array}{l}\text { Scientific Electronic Library Online (SciELO); } \\
\text { Google Acadêmico; Revistas Eletrônicas. }\end{array}$ \\
\hline \multirow[t]{2}{*}{$2^{a}$} & Período de coleta dos dados & Março a maio de 2020. \\
\hline & Critérios de inclusão & $\begin{array}{l}\text { Texto completo (disponível/free) do tipo: artigo } \\
\text { original, artigo de revisão, artigo na imprensa, recurso, }\end{array}$ \\
\hline
\end{tabular}




\begin{tabular}{|c|c|c|}
\hline & & $\begin{array}{l}\text { editorial, perspectiva e pesquisa transacional; } \\
\text { Publicação }(2014-2020) \text {. }\end{array}$ \\
\hline & Critérios de exclusão & $\begin{array}{l}\text { Livros, monografias, Trabalho de Conclusão de Curso, } \\
\text { Resumos, Relatórios, Teses e Dissertações; Artigos } \\
\text { que não contemplavam a relação entre a } \\
\text { interculturalidade e educação indígena. }\end{array}$ \\
\hline $3^{a}$ & $\begin{array}{c}\text { Número de trabalhos } \\
\text { selecionados para revisão } \\
\text { sistemática integrativa a partir } \\
\text { da leitura dos agentes } \\
\text { indexadores das publicações } \\
\text { (resumo, palavras-chave e } \\
\text { título) e resultados, os quais } \\
\text { deveriam conter os descritores } \\
\text { utilizados nesse estudo }\end{array}$ & 30 trabalhos \\
\hline $4^{\mathrm{a}}$ & $\begin{array}{c}\text { Categorias obtidas com a } \\
\text { análise dos trabalhos científicos } \\
\text { investigados }\end{array}$ & $\begin{array}{l}\text { - A construção de um currículo sob a perspectiva da } \\
\text { multiculturalidade; } \\
\text { - A Lei no } 11.645 / 2008 \text { e a inserção da temática } \\
\text { indígena no currículo escolar; } \\
\text { - A educação musical inclusiva e o respeito às } \\
\text { diferenças: uma possibilidade para o ensino das } \\
\text { músicas indígenas. }\end{array}$ \\
\hline $5^{\mathrm{a}}$ & $\begin{array}{l}\text { Análise, interpretação e } \\
\text { discussão dos resultados }\end{array}$ & Ver em "Resultados e Discussão" \\
\hline $6^{\mathrm{a}}$ & $\begin{array}{l}\text { Apresentação da revisão em } \\
\text { formato de artigo, o qual } \\
\text { contemple propostas para } \\
\text { estudos futuros }\end{array}$ & Esse Artigo completo \\
\hline
\end{tabular}

Fonte: elaborada pela autora (2020).

\section{RESULTADOS E DISCUSSÃO}

Considerando os critérios de inclusão estabelecidos durante a pesquisa foram selecionados 30 artigos que contemplavam a relação entre a questão multicultural do currículo escolar e sua relação com a educação dos povos indígenas, conforme descritos resumidamente no Quadro 2.

Quadro 02 - Levantamento de Publicações Científicas de Acordo com os Critérios de Inclusão.

\begin{tabular}{|c|c|c|c|c|c|}
\hline $\mathbf{N}^{\circ}$ & CITAÇÃO & TEMA & ANO & $\begin{array}{c}\text { OBJETIVO DO } \\
\text { ESTUDO }\end{array}$ & $\begin{array}{c}\text { CONCLUSÃO DO } \\
\text { ESTUDO }\end{array}$ \\
\hline 1 & $\begin{array}{l}\text { FELIPE, D. A.; } \\
\text { FRANÇA, F. F. }\end{array}$ & $\begin{array}{l}\text { A diversidade na } \\
\text { educação escolar: o } \\
\text { currículo como } \\
\text { artefato cultural. }\end{array}$ & 2014 & 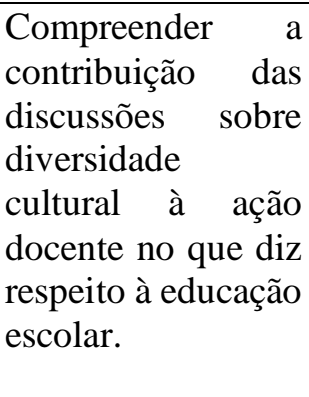 & $\begin{array}{lr}\text { Trabalhar } & \text { na } \\
\text { perspectiva } & \text { da } \\
\text { diversidade } & \text { cultural, } \\
\text { na educação escolar } \\
\text { por meio do currículo } \\
\text { significa efetivar uma } \\
\text { pedagogia } \\
\text { propostas a com } \\
\text { formação } & \text { docente } \\
\end{array}$ \\
\hline
\end{tabular}




\begin{tabular}{|c|c|c|c|c|c|}
\hline & & & & & $\begin{array}{l}\text { que problematiza as } \\
\text { práticas cotidianas. }\end{array}$ \\
\hline 2 & $\begin{array}{l}\text { FRIGE, A. A. C. } \\
\text { et al. }\end{array}$ & $\begin{array}{l}\text { A importância de } \\
\text { um currículo } \\
\text { multicultural nas } \\
\text { aulas de educação } \\
\text { física. }\end{array}$ & 2016 & 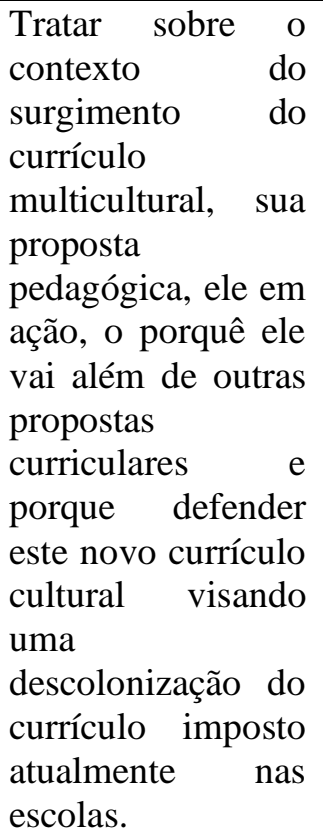 & $\begin{array}{l}\text { É extremamente } \\
\text { importante } \\
\text { fundamental que o } \\
\text { professor } \\
\text { preparado } \\
\text { aplicar } \\
\text { conhecimentos ara } \\
\text { alunos e que consiga } \\
\text { mostrar as todos que } \\
\text { a sociedade é ampla e } \\
\text { com diversas } \\
\text { culturas, com isso } \\
\text { ajudará aos alunos } \\
\text { que construam uma } \\
\text { sociedade menos } \\
\text { desigual. }\end{array}$ \\
\hline 3 & REIS, D. A. & $\begin{array}{c}\text { Currículo } \\
\text { multi/intercultural } \\
\text { no contexto escolar: } \\
\text { implicações para a } \\
\text { prática docente }\end{array}$ & 2014 & $\begin{array}{l}\text { Refletir sobre p } \\
\text { multiculturalismo e } \\
\text { o interculturalismo, } \\
\text { como perspectivas } \\
\text { educacionais, } \\
\text { associando-os ao } \\
\text { currículo escolar. }\end{array}$ & $\begin{array}{l}\text { Um currículo } \\
\text { multi/intercultural é } \\
\text { para todos, está } \\
\text { voltado para formar } \\
\text { sujeitos na/para uma } \\
\text { cidadania ativa e, por } \\
\text { sua vez, deverá ter } \\
\text { como princípio } \\
\text { norteador o sucesso } \\
\text { de todos na escola. } \\
\text { Com este propósito, à } \\
\text { escola compete o } \\
\text { desafio de assumir } \\
\text { novos arranjos } \\
\text { pedagógico- } \\
\text { curriculares } \\
\text { refletindo os } \\
\text { percursos formativos } \\
\text { dos alunos e alunos, } \\
\text { desenvolvendo } \\
\text { ativamente e de } \\
\text { maneira } \\
\text { compartilhada } \\
\text { coletiva o seu papel } \\
\text { educativo. }\end{array}$ \\
\hline 4 & $\begin{array}{l}\text { OLIVEIRA, A. } \\
\text { G. }\end{array}$ & $\begin{array}{c}\text { Indagações sobre } \\
\text { currículo: } \\
\text { desenvolvimento } \\
\text { humano, } \\
\text { multiculturalismo e } \\
\text { diversidade. }\end{array}$ & 2016 & $\begin{array}{lr}\text { Realizar } & \text { uma } \\
\text { investigação } & \text { em } \\
\text { torno } & \text { das } \\
\text { indagações } & \text { sobre } \\
\text { currículo a partir de } \\
\text { uma perspectiva de } \\
\text { desenvolvimento } \\
\text { humano, } \\
\text { multiculturalismo e }\end{array}$ & $\begin{array}{lr}\text { A prática curricular } \\
\text { dos docentes enfatiza } \\
\text { o currículo } \\
\text { impositivo, já que os } \\
\text { conteúdos ra são } \\
\text { apresentados } \\
\text { alunos em sala de } \\
\text { aula como algo } \\
\text { desvinculado da }\end{array}$ \\
\hline
\end{tabular}




\begin{tabular}{|c|c|c|c|c|c|}
\hline & & & & $\begin{array}{l}\text { diversidade } \\
\text { cultural. }\end{array}$ & $\begin{array}{l}\text { cultura } \\
\text { historicamente } \\
\text { construída, dos } \\
\text { valores, dos } \\
\text { conhecimentos } \\
\text { prévios dos alunos e, } \\
\text { da diversidade } \\
\text { cultural. }\end{array}$ \\
\hline 5 & $\begin{array}{l}\text { DOMINGUES, } \\
\text { M. D. B. }\end{array}$ & $\begin{array}{l}\text { História indígena } \\
\text { escolar: discursos } \\
\text { em circulação. }\end{array}$ & 2014 & $\begin{array}{l}\text { Apresentar um } \\
\text { breve mapeamento } \\
\text { dos debates } \\
\text { políticos e } \\
\text { epistemológico } \\
\text { acerca da história } \\
\text { indígena escolar, } \\
\text { que circulam nos } \\
\text { campos do } \\
\text { currículo e do } \\
\text { ensino de História. }\end{array}$ & $\begin{array}{l}\text { Tema recorrente nas } \\
\text { análises pós- } \\
\text { coloniais, a temática } \\
\text { da interculturalidade } \\
\text { crítica, no quadro da } \\
\text { crítica decolonial, } \\
\text { mostrou-se } \\
\text { igualmente profícua } \\
\text { como uma das } \\
\text { apostas teóricas nas } \\
\text { análises que buscam } \\
\text { fazer avançar os } \\
\text { debates da diferença } \\
\text { e da tensão universal } \\
\text { e particular no campo } \\
\text { curricular, neste caso, } \\
\text { acerca da história } \\
\text { indígena escolar no } \\
\text { âmbito da história } \\
\text { nacional. }\end{array}$ \\
\hline 6 & $\begin{array}{l}\text { NASCIMENTO, } \\
\text { R. G. }\end{array}$ & $\begin{array}{l}\text { Escola como local } \\
\text { das culturas: o que } \\
\text { dizem os índios } \\
\text { sobre escola e } \\
\text { currículo. }\end{array}$ & 2017 & $\begin{array}{l}\text { Apresentar uma } \\
\text { reflexão sobre } \\
\text { pluralidade } \\
\text { curricular que toma } \\
\text { a cultura, ao lado } \\
\text { de identidade, } \\
\text { como categorias } \\
\text { centrais. }\end{array}$ & $\begin{array}{l}\text { Nos currículos das } \\
\text { escolas indígenas, as } \\
\text { demandas postas por } \\
\text { reconhecimento e por } \\
\text { direitos } \\
\text { diferenciados, podem } \\
\text { ser um importante } \\
\text { contraponto no } \\
\text { horizonte de uma } \\
\text { narrativa curricular } \\
\text { hegemônica, no } \\
\text { mínimo, desatenta às } \\
\text { diferenças presenças } \\
\text { nas salas de aula, bem } \\
\text { como aos diferentes } \\
\text { projetos escolares e } \\
\text { societários. }\end{array}$ \\
\hline 7 & IVENICKI, A. & $\begin{array}{l}\text { Multiculturalismo e } \\
\text { formação de } \\
\text { professores: } \\
\text { dimensões, } \\
\text { possibilidades e } \\
\text { desafios na } \\
\text { contemporaneidade. }\end{array}$ & 2018 & $\begin{array}{l}\text { Destacar aspectos } \\
\text { técnico-científicos } \\
\text { que podem } \\
\text { contribuir para o } \\
\text { campo da formação } \\
\text { de professores, } \\
\text { com o olhar } \\
\text { multicultural, sobre } \\
\text { o currículo e as }\end{array}$ & \begin{tabular}{lr}
\multicolumn{3}{l}{ O olhar multicultural } \\
sobre a pesquisa e sua \\
articulação \\
conhecimento \\
desenvolvido \\
currículo \\
formação \\
professores, \\
defendido a partir dos \\
\end{tabular} \\
\hline
\end{tabular}




\begin{tabular}{|c|c|c|c|c|c|}
\hline & & & & $\begin{array}{l}\text { práticas didático- } \\
\text { pedagógicas. }\end{array}$ & $\begin{array}{l}\text { três } \\
\text { argumentativos } \\
\text { basilares do presente } \\
\text { texto, pretende } \\
\text { representar uma } \\
\text { contribuição para o } \\
\text { campo, sendo ela } \\
\text { própria, parte de uma } \\
\text { agenda de pesquisa, } \\
\text { em construção e } \\
\text { reconstrução } \\
\text { permanentes, no } \\
\text { horizonte de uma } \\
\text { formação } \\
\text { cidadania mais ética, } \\
\text { plural e participativa. }\end{array}$ \\
\hline 8 & SOUZA, C. G. & $\begin{array}{l}\text { Projeto sagrada } \\
\text { natureza: currículo } \\
\text { em ação - uma } \\
\text { experiência } \\
\text { multicultural na } \\
\text { aplicação da Lei } \\
11.645 / 2008 .\end{array}$ & 2019 & $\begin{array}{lr}\text { Analisar, } & \text { como } \\
\text { pesquisa } & \\
\text { qualitativa, } & \text { uma } \\
\text { experiência } & \text { de } \\
\text { currículo em } & \text { ação } \\
\text { desenvolvida } & \text { em } \\
\text { cinco escolas } & \text { de } \\
\text { rede municipal } & \text { de } \\
\text { educação } & \text { de } \\
\text { Niterói. } & \end{array}$ & 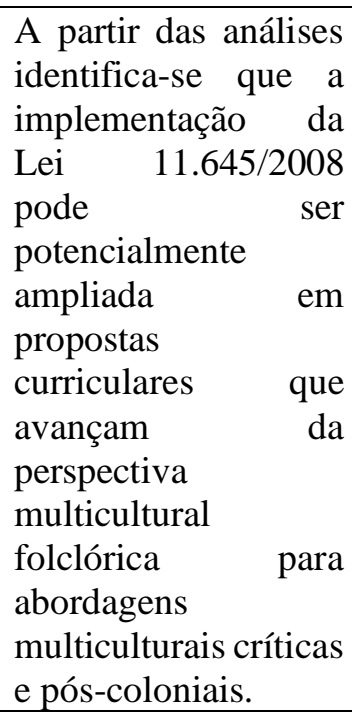 \\
\hline 9 & $\begin{array}{l}\text { MALANCHEN, } \\
\text { J. }\end{array}$ & $\begin{array}{l}\text { Pedagogia histórico- } \\
\text { crítica e saber } \\
\text { objetivo versus } \\
\text { multiculturalismo e } \\
\text { o relativismo no } \\
\text { debate curricular } \\
\text { atual }\end{array}$ & 2015 & $\begin{array}{l}\text { Explicitar as bases } \\
\text { pós-moderna e } \\
\text { relativistas do } \\
\text { multiculturalismo, } \\
\text { que se opõe, a } \\
\text { defesa do saber } \\
\text { objetivo romo } \\
\text { central na } \\
\text { organização de um } \\
\text { currículo. }\end{array}$ & $\begin{array}{l}\text { A escola deve ser } \\
\text { uma instituição onde } \\
\text { o trabalho } \\
\text { desenvolvido } \\
\text { possibilite que o } \\
\text { universal do gênero } \\
\text { humano se encontre } \\
\text { com o singular e os } \\
\text { diversos modos de } \\
\text { ser humano, } \\
\text { produzindo assim a } \\
\text { humanidade } \\
\text { historicamente } \\
\text { acumulada. } \\
\text { Compreendemos, } \\
\text { portanto que acesso } \\
\text { ao saber } \\
\text { sistematizado, o } \\
\text { saber subjetivo, } \\
\text { possibilita o combate } \\
\text { ao preconceito, ao } \\
\text { desmitificar crenças e }\end{array}$ \\
\hline
\end{tabular}




\begin{tabular}{|c|c|c|c|c|c|}
\hline & & & & & $\begin{array}{l}\text { evidenciar } \\
\text { superficialidade de } \\
\text { alguns argumentos e } \\
\text { atitudes em relação a } \\
\text { alguns grupos } \\
\text { sociais. }\end{array}$ \\
\hline 10 & $\begin{array}{l}\text { GUERRA, M. G. } \\
\text { G. V. et al. }\end{array}$ & $\begin{array}{l}\text { Por um currículo } \\
\text { plural na perspectiva } \\
\text { do multiculturalismo }\end{array}$ & 2018 & $\begin{array}{l}\text { Discutir questões } \\
\text { do cenário das } \\
\text { políticas } \\
\text { educacionais em } \\
\text { função ra } \\
\text { diversidade étnico- } \\
\text { racial, da } \\
\text { interculturalidade e } \\
\text { do } \\
\text { multiculturalismo } \\
\text { na busca de } \\
\text { compreensão de } \\
\text { como esse cenário } \\
\text { pode contribuir } \\
\text { para uma prática } \\
\text { docente } \\
\text { compromissada } \\
\text { com as demandas } \\
\text { sociais. }\end{array}$ & 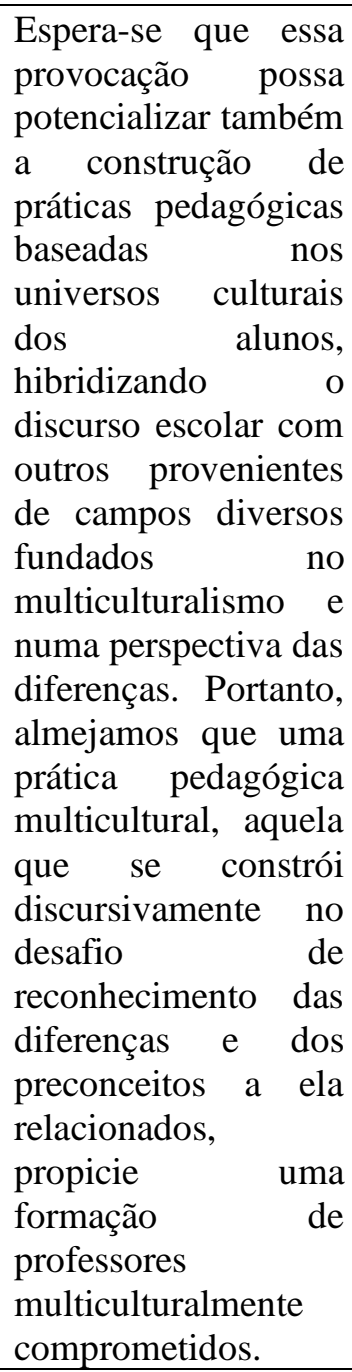 \\
\hline 11 & $\begin{array}{l}\text { ALMEIDA } \\
\text { NETO, A. S. }\end{array}$ & $\begin{array}{l}\text { A história indígena a } \\
\text { ser ensinada nos } \\
\text { currículos oficiais } \\
\text { brasileiros. }\end{array}$ & 2015 & $\begin{array}{l}\text { Analisar algumas } \\
\text { propostas } \\
\text { curriculares } \\
\text { oficiais, partindo } \\
\text { do pressuposto de } \\
\text { que a Lei } \\
11.645 / 2008 \text {, por } \\
\text { ser federal, deve } \\
\text { ser aplicada por } \\
\text { todos os estados da } \\
\text { federação, quando } \\
\text { da elaboração de } \\
\text { suas diretrizes para } \\
\text { a educação. }\end{array}$ & $\begin{array}{l}\text { Tais propostas } \\
\text { representam formas } \\
\text { paradigmáticas, } \\
\text { diferentes entre si, de } \\
\text { pensar o currículo } \\
\text { escolar, guiando-se } \\
\text { por competências e } \\
\text { habilidades ou } \\
\text { expectativas de } \\
\text { aprendizagem, } \\
\text { indicando temas ou } \\
\text { prescrevendo } \\
\text { conteúdos, sugerindo } \\
\text { possíveis abordagens } \\
\text { ou determinando } \\
\text { atividades } \\
\text { apostiladas. }\end{array}$ \\
\hline
\end{tabular}




\begin{tabular}{|c|c|c|c|c|c|}
\hline & & & & & 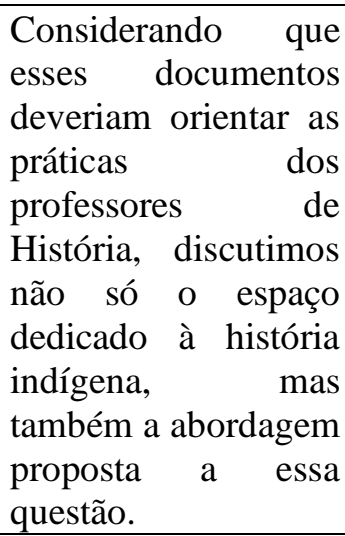 \\
\hline 12 & $\begin{array}{c}\text { CREPALDI, E. } \\
\text { M. F. }\end{array}$ & $\begin{array}{c}\text { Currículo e } \\
\text { multiculturalismo: } \\
\text { perspectivas para } \\
\text { consciencialização } \\
\text { das diferenças na } \\
\text { escola. }\end{array}$ & 2015 & $\begin{array}{l}\text { Contribuir para a } \\
\text { identificação e } \\
\text { consciencialização } \\
\text { da problemática } \\
\text { existente no campo } \\
\text { educativo assim } \\
\text { como possibilitar } \\
\text { aos professores a } \\
\text { compreensão do } \\
\text { risco da escola } \\
\text { representar uma } \\
\text { mera reprodução } \\
\text { de projetos } \\
\text { hegemônicos. }\end{array}$ & $\begin{array}{l}\text { O multiculturalismo } \\
\text { na escola pode ser } \\
\text { entendido como } \\
\text { possibilidade de } \\
\text { inclusão de todos à } \\
\text { educação, } \\
\text { independente das } \\
\text { diversidades e dos } \\
\text { grupos minoritários, } \\
\text { geralmente excluídos } \\
\text { e marginalizados. } \\
\text { Um currículo } \\
\text { ampliado abrangerá } \\
\text { as necessidades dos } \\
\text { grupos minoritários e } \\
\text { reconhecerá } \\
\text { singularidade dos } \\
\text { indivíduos. }\end{array}$ \\
\hline 13 & $\begin{array}{l}\text { MACHADO, C. } \\
\text { B.; LEON, A. D. }\end{array}$ & $\begin{array}{c}\text { O movimento } \\
\text { indígena e a } \\
\text { educação escolar. }\end{array}$ & 2019 & $\begin{array}{l}\text { Compreender } \\
\text { como o movimento } \\
\text { Indígena, tem } \\
\text { influenciado as leis } \\
\text { que orientam o } \\
\text { ensino da temática } \\
\text { indígena na escola, } \\
\text { principalmente no } \\
\text { que diz respeito à } \\
\text { valorização das } \\
\text { diferentes culturas } \\
\text { e histórico desses } \\
\text { povos. }\end{array}$ & $\begin{array}{l}\text { A partir desse estudo, } \\
\text { pode-se perceber que } \\
\text { o movimento } \\
\text { Indígena } \\
\text { crescido } \\
\text { influenciado } \\
\text { criação } \\
\text { normativas } \\
\text { tornam a temática } \\
\text { indígena, de certa } \\
\text { forma, presente nos } \\
\text { currículos escolares } \\
\text { e, aos poucos, na } \\
\text { realidade das escolas } \\
\text { brasileiras. }\end{array}$ \\
\hline 14 & $\begin{array}{c}\text { BRIGHENTI, C. } \\
\text { A. }\end{array}$ & $\begin{array}{l}\text { Decolonialidade, } \\
\text { ensino e povos } \\
\text { indígenas: uma } \\
\text { reflexão sobre a lei } \\
\text { no }^{\circ} 11.645 .\end{array}$ & 2015 & $\begin{array}{l}\text { Realizar uma } \\
\text { análise crítica da } \\
\text { Lei } 11.645 \text { de } 2008 \\
\text { que modificou as } \\
\text { Diretrizes e Bases } \\
\text { da Educação } \\
\text { Nacional para } \\
\text { incluir no currículo } \\
\text { oficial da rede de } \\
\text { ensino a }\end{array}$ & $\begin{array}{l}\text { Como mecanismo de } \\
\text { superação } \\
\text { efetivação da } \\
\text { apontamos } \\
\text { perspectiva } \\
\text { decolonialidade, } \\
\text { entendida como uma } \\
\text { forma de superação } \\
\text { do padrão mundial de } \\
\text { poder capitalista, que }\end{array}$ \\
\hline
\end{tabular}




\begin{tabular}{|c|c|c|c|c|c|}
\hline & & & & $\begin{array}{l}\text { obrigatoriedade da } \\
\text { temática História e } \\
\text { Cultura Indígena. }\end{array}$ & $\begin{array}{l}\text { mesmo com as } \\
\text { independências } \\
\text { nacionais dos países } \\
\text { da América Latina } \\
\text { dos impérios ibéricos } \\
\text { continua a existir na } \\
\text { sociedade ocidental. } \\
\text { Também apontamos } \\
\text { a interculturalidade } \\
\text { crítica como } \\
\text { elemento central para } \\
\text { criação de uma } \\
\text { escola/sociedade } \\
\text { pluricultural. }\end{array}$ \\
\hline 15 & FERREIRA, B. & $\begin{array}{l}\text { Decolonizando a } \\
\text { escola: em busca de } \\
\text { novas práticas. }\end{array}$ & 2018 & $\begin{array}{l}\text { Desencobrir novas } \\
\text { práticas para a } \\
\text { construção de uma } \\
\text { escola que respeite } \\
\text { os processos } \\
\text { próprios } \\
\text { construir de } \\
\text { transmitir } \\
\text { conhecimentos dos } \\
\text { Kaingang. }\end{array}$ & $\begin{array}{l}\text { A } \\
\text { colonizadora nega a } \\
\text { existência de outras } \\
\text { culturas e, dessa } \\
\text { forma, (in) visibiliza } \\
\text { os povos indígenas, } \\
\text { que são colocadas } \\
\text { numa categoria } \\
\text { subalterna e inferior } \\
\text { da chamada } \\
\text { sociedade civilizada } \\
\text { branca. Diante disso, } \\
\text { a descolonização da } \\
\text { educação escolar é } \\
\text { urgente, a fim de } \\
\text { valorizar e considerar } \\
\text { os conhecimentos } \\
\text { indígenas sobretudo } \\
\text { suas histórias, } \\
\text { culturas e línguas, } \\
\text { bem como as práticas } \\
\text { educativas. }\end{array}$ \\
\hline 16 & $\begin{array}{c}\text { ALMEIDA } \\
\text { NETO, A. S. }\end{array}$ & $\begin{array}{l}\text { Ensino de história } \\
\text { indígena: currículo, } \\
\text { identidade e } \\
\text { diferença. }\end{array}$ & 2014 & 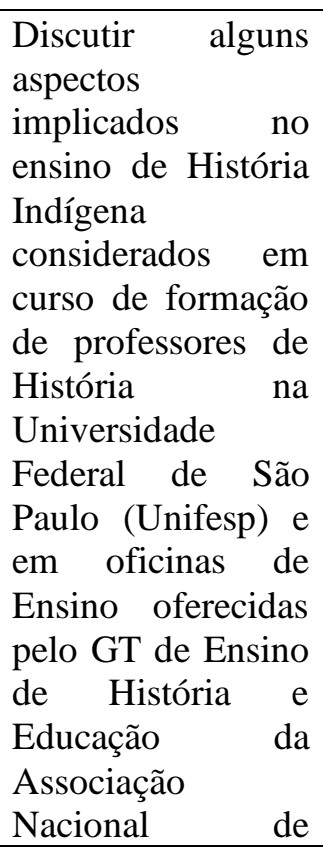 & \begin{tabular}{lr}
\multicolumn{3}{l}{ Sendo a produção da } \\
identidade e da \\
diferença \\
território disputado, o \\
ensino de História \\
pode e deve inserir \\
outras narrativas que \\
subvertam \\
estabilidade que das \\
representações \\
dominantes, \\
questionem \\
mecanismos \\
instituições \\
reprodução \\
identidades, \\
estimulem \\
desequilíbrio poiético \\
- ato criativo - que
\end{tabular} \\
\hline
\end{tabular}




\begin{tabular}{|c|c|c|c|c|c|}
\hline & & & & $\begin{array}{l}\text { História, seção São } \\
\text { Paulo (ANPVH- } \\
\text { SP), para disparar } \\
\text { algumas reflexões } \\
\text { sobre a temática. }\end{array}$ & 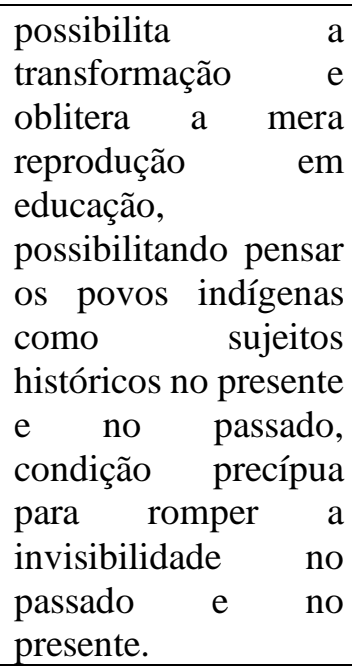 \\
\hline 17 & $\begin{array}{l}\text { AMÉRICO, M. } \\
\text { C. }\end{array}$ & $\begin{array}{c}\text { Formação de } \\
\text { professores para a } \\
\text { implementação da } \\
\text { Lei 10.639/2003: o } \\
\text { ensino da História e } \\
\text { Cultura Afro- } \\
\text { Brasileira e Indígena } \\
\text { no Currículo } \\
\text { Escolar. }\end{array}$ & 2014 & $\begin{array}{l}\text { Apresentar } \\
\text { algumas reflexões } \\
\text { sobre } \\
\text { implementação da } \\
\text { Lei 10.639/2003, } \\
\text { alterada pela Lei } \\
11.645 / 2008 \text {. }\end{array}$ & $\begin{array}{lr}\text { A formação de } \\
\text { profissionalismo da } \\
\text { educação, embasada } \\
\text { teoricamente na } \\
\text { compreensão dos } \\
\text { fundamentos da lei e } \\
\text { em ações que visem a } \\
\text { sua implementação, } \\
\text { possibilita que a } \\
\text { infância nas } \\
\text { instituições } \\
\text { educacionais seja } \\
\text { tratada como uma } \\
\text { construção histórica, } \\
\text { social, cultural e } \\
\text { política. }\end{array}$ \\
\hline 18 & ARAÚJO, I. A. & $\begin{array}{l}\text { Temática indígena } \\
\text { na escola: } \\
\text { potencialidades do } \\
\text { currículo para o } \\
\text { enfrentamento da } \\
\text { colonialidade. }\end{array}$ & 2014 & $\begin{array}{lr}\text { Problematizar } & \text { os } \\
\text { processos } & \text { que } \\
\text { envolvem } & \text { a } \\
\text { concretização } & \text { da } \\
\text { Lei 11.645/2008 no } \\
\text { cotidiano da } \\
\text { escola, a partir de } \\
\text { uma análise do } \\
\text { currículo de uma } \\
\text { rede municipal de } \\
\text { educação } \\
\text { Baixada na } \\
\text { Fluminense. }\end{array}$ & $\begin{array}{l}\text { É essencial que } \\
\text { intensifiquemos a } \\
\text { discussão } \\
\text { problematização a } \\
\text { história e culturas } \\
\text { indígenas vistas de } \\
\text { forma exótica, } \\
\text { eurocentrada, } \\
\text { descontextualizada e } \\
\text { que avancemos na } \\
\text { construção de outros } \\
\text { cenários em que } \\
\text { crianças e jovens } \\
\text { aprendam outras } \\
\text { histórias, outros } \\
\text { conhecimentos, } \\
\text { outras visões. }\end{array}$ \\
\hline 19 & SILVA, E. & $\begin{array}{l}\text { Os povos indígenas } \\
\text { e o ensino: } \\
\text { possibilidades, } \\
\text { desafios e impasses } \\
\text { a partir da Lei } \\
11.645 / 2008 .\end{array}$ & 2015 & $\begin{array}{lr}\text { Realizar } & \text { um } \\
\text { balanço crítico a } \\
\text { respeito } & \text { da } \\
\text { implementação } & \text { da } \\
\text { Lei 11.645/2008 a } & \text { partir } \\
\text { constatação } & \text { da }\end{array}$ & $\begin{array}{l}\text { O estudo da temática } \\
\text { indígena, além de } \\
\text { questionar visões } \\
\text { colonizadoras, } \\
\text { ufanismos } \\
\text { concepções } \\
\text { deterministas sobre o }\end{array}$ \\
\hline
\end{tabular}




\begin{tabular}{|c|c|c|c|c|c|}
\hline & & & & $\begin{array}{l}\text { algumas } \\
\text { possibilidades, } \\
\text { desafios } \\
\text { impasses. }\end{array}$ & $\begin{array}{lr}\text { lugar dos povos } \\
\text { indígenas na História } \\
\text { do Brasil, possibilita } \\
\text { repensar a História, } \\
\text { superar estereótipos, } \\
\text { equívocos, ré- } \\
\text { conceito e } \text { (re) } \\
\text { conhecer } \\
\text { significados os } \\
\text { riqueza que são as } \\
\text { socio diversidade } \\
\text { indígenas em nosso } \\
\text { país. }\end{array}$ \\
\hline 20 & $\begin{array}{l}\text { SANTIAGO, R.; } \\
\text { IVENICKI, A. }\end{array}$ & $\begin{array}{l}\text { Diversidade musical } \\
\text { e formação de } \\
\text { professores: qual } \\
\text { musica forma o(a) } \\
\text { professor (a) de } \\
\text { música? }\end{array}$ & 2017 & $\begin{array}{lr}\text { Analisar sob um } \\
\text { olhar multicultural } \\
\text { o r repertório } \\
\text { utilizado rra na } \\
\text { formação } & \text { de } \\
\text { professores (as) de } \\
\text { música de três } \\
\text { instituições r de } \\
\text { ensino superior da } \\
\text { cidade do Rio de } \\
\text { Janeiro. }\end{array}$ & $\begin{array}{lr}\text { De forma geral os } \\
\text { (as) futuros (as) } \\
\text { professores (as) de } \\
\text { música são formados } \\
\text { para lecionar por } \\
\text { meio de músicas } \\
\text { elitizadas de tradição } \\
\text { europeia. Contudo, } \\
\text { lentamente, as } \\
\text { licenciaturas em } \\
\text { música tem se aberto } \\
\text { para } \\
\text { musicalidades, como } \\
\text { a música "popular", } \\
\text { mas as músicas } \\
\text { preferidas dos (as) } \\
\text { estudantes r da } \\
\text { educação básica } \\
\text { continuam de fora do } \\
\text { currículo do ensino } \\
\text { superior. }\end{array}$ \\
\hline 21 & $\begin{array}{l}\text { FIGUEIREDO, } \\
\text { S. L. F.; } \\
\text { MEURER, R. P. }\end{array}$ & $\begin{array}{l}\text { Educação musical } \\
\text { no currículo escolar: } \\
\text { uma análise dos } \\
\text { impactos da Lei n. } \\
11.769 / 2008 .\end{array}$ & 2016 & 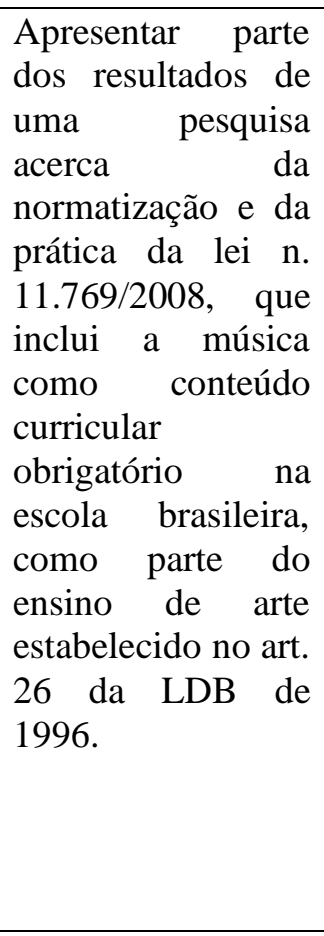 & $\begin{array}{l}\text { Os resultados da } \\
\text { pesquisa evidenciam } \\
\text { algum impacto da lei } \\
\text { n. } 11.769 / 2008 \text { em } \\
\text { distintos sistemas } \\
\text { educacionais, } \\
\text { principalmente a } \\
\text { partir da existência de } \\
\text { vagas especificas } \\
\text { para licenciados em } \\
\text { música nos editais } \\
\text { pesquisados, o que } \\
\text { implica } \\
\text { determinados que } \\
\text { sistemas } \\
\text { educacionais estão } \\
\text { atentos à inserção da } \\
\text { música } \\
\text { componente como } \\
\text { curricular } \\
\text { obrigatório. }\end{array}$ \\
\hline
\end{tabular}




\begin{tabular}{|c|c|c|c|c|c|}
\hline 22 & FRAGOSO, D. & $\begin{array}{c}\text { Educação musical e } \\
\text { diversidade: uma } \\
\text { experiência entre } \\
\text { crianças } \\
\text { Guaraniribya e } \\
\text { crianças não } \\
\text { indígenas. }\end{array}$ & 2015 & $\begin{array}{l}\text { Discutir sobre } \\
\text { cultura, música e } \\
\text { diversidade } \\
\text { aplicadas a práticas } \\
\text { transculturais em } \\
\text { educação musical a } \\
\text { partir do trabalho } \\
\text { de pesquisa } \\
\text { desenvolvido em } \\
\text { um grupo coral } \\
\text { infantil guarani da } \\
\text { aldeia Tenondé } \\
\text { Porã e um grupo de } \\
\text { coro infantil não } \\
\text { indígena } \\
\text { pertencente a um } \\
\text { centro comunitário. }\end{array}$ & $\begin{array}{l}\text { A inclusão de } \\
\text { músicas de outros } \\
\text { povos e culturas no } \\
\text { repertório escolar ou } \\
\text { coral pode } \\
\text { desconstruir } \\
\text { estereótipos } \\
\text { desestimular posturas } \\
\text { preconceituosas e } \\
\text { esta prática remete à } \\
\text { diversidade ao } \\
\text { mesmo tempo em que } \\
\text { nela se realiza. }\end{array}$ \\
\hline 23 & HERBETIA, A. & $\begin{array}{l}\text { Entre a cantoria e a } \\
\text { sala de aula: } \\
\text { reflexões sobre o } \\
\text { papel da música em } \\
\text { novas matrizes } \\
\text { curriculares de } \\
\text { escolas Timbira. }\end{array}$ & 2016 & $\begin{array}{l}\text { Analisar o papel da } \\
\text { música em algumas } \\
\text { experiências de } \\
\text { reformulação de } \\
\text { matrizes } \\
\text { curriculares em } \\
\text { escolas indígenas } \\
\text { do Brasil Central, } \\
\text { especialmente em } \\
\text { populações } \\
\text { Timbira, como os } \\
\text { Krahô, Apinajé, } \\
\text { Gavião e Krinati. }\end{array}$ & $\begin{array}{l}\text { A possibilidade de } \\
\text { cada escola indígena } \\
\text { usar os modos } \\
\text { particulares } \\
\text { aprendizagem, abre a } \\
\text { possibilidade de se } \\
\text { criarem modelos } \\
\text { inovadores } \\
\text { educação. } \\
\text { conquistas Tais } \\
\text { relação com uma } \\
\text { nova percepção de } \\
\text { música, esta, em } \\
\text { acordo com a } \\
\text { discussão } \\
\text { contemporânea } \\
\text { acerca do tema em } \\
\text { tela, aponta para a } \\
\text { necessidade } \\
\text { premente de uma } \\
\text { centralidade } \\
\text { educação musical, a } \\
\text { qual deve ter como } \\
\text { características a } \\
\text { transdisciplinaridade } \\
\text { a particularidade de } \\
\text { cada cultura. }\end{array}$ \\
\hline 24 & SILVA, M. P. & $\begin{array}{c}\text { Experiências } \\
\text { musicais no espaço } \\
\text { escolar: narrativas } \\
\text { de jovens indígenas. }\end{array}$ & 2017 & $\begin{array}{lr}\text { Apresentar } & \text { um } \\
\text { recorte de pesquisa } \\
\text { concluída que teve } \\
\text { como } & \text { objetivo } \\
\text { investigar } & \text { os } \\
\text { modos } & \text { como } \\
\text { jovens indígenas } \\
\text { do Instituto Federal } \\
\text { do Pará - campus } \\
\text { Rural de } & \text { Marabá } \\
\text { constituem rasas }\end{array}$ & $\begin{array}{lr}\text { Resultados } & \text { da } \\
\text { pesquisa apontaram } \\
\text { que } \\
\text { colaboradores } \\
\text { querem consecer } \\
\text { outras rulturas, } \\
\text { aprender r outras } \\
\text { músicas. E nesse jeito } \\
\text { de aprender estão } \\
\text { abertos tanto para } \\
\text { aprendizagens de }\end{array}$ \\
\hline
\end{tabular}




\begin{tabular}{|c|c|c|c|c|c|}
\hline & & & & $\begin{array}{l}\text { experiências } \\
\text { musicais. }\end{array}$ & $\begin{array}{l}\text { códigos musicais } \\
\text { escritos, quanto à } \\
\text { transmissão musical } \\
\text { pela oralidade. } \\
\text { Processos esses que } \\
\text { nos ajudam a pensar } \\
\text { em uma educação } \\
\text { musical indígena } \\
\text { intercultural, cujos } \\
\text { aspectos relacionados } \\
\text { a como fazer, com o } \\
\text { ensinar e como } \\
\text { aprender estão em } \\
\text { constante diálogo e } \\
\text { promovendo valores } \\
\text { advindos de campos } \\
\text { filosóficos, } \\
\text { antropológicos } \\
\text { sociológicos. }\end{array}$ \\
\hline 25 & $\begin{array}{l}\text { ALMEIDA, B.; } \\
\text { PUCCI, M. }\end{array}$ & $\begin{array}{l}\text { Há espaço para as } \\
\text { músicas indígenas } \\
\text { em um Brasil } \\
\text { multicultural? - a } \\
\text { inserção do } \\
\text { repertório indígena } \\
\text { na educação } \\
\text { musical. }\end{array}$ & 2014 & $\begin{array}{l}\text { Comentar a } \\
\text { pesquisa em } \\
\text { andamento sobre as } \\
\text { músicas de alguns } \\
\text { povos indígenas e a } \\
\text { sua aplicação em } \\
\text { sala de aula, assim } \\
\text { com o } \\
\text { desenvolvimento } \\
\text { de materiais } \\
\text { didáticos. }\end{array}$ & $\begin{array}{lr}\text { Em geral, livros de } \\
\text { contos e } & \text { mitos } \\
\text { indígenas } & \text { tem } \\
\text { surgido, } & \text { porém, } \\
\text { materiais } & \text { que } \\
\text { contemplem } & \text { as } \\
\text { músicas indígenas } \\
\text { são raros, visto que é } \\
\text { uma área pouco } \\
\text { pesquisada por } \\
\text { educadores musicais. } \\
\text { O fato é que as } \\
\text { pesquisas acadêmicas } \\
\text { sobre ralturas } \\
\text { musicais indígenas } \\
\text { pouco ecoam na } \\
\text { educação musical } \\
\text { como seria desejável. }\end{array}$ \\
\hline 26 & $\begin{array}{l}\text { SANTIAGO. R.; } \\
\text { IVENICKI, A. }\end{array}$ & $\begin{array}{l}\text { Multiculturalismo } \\
\text { na formação de } \\
\text { professores de } \\
\text { música: o caso de } \\
\text { três instituições de } \\
\text { ensino superior da } \\
\text { cidade do Rio de } \\
\text { Janeiro. }\end{array}$ & 2016 & $\begin{array}{l}\text { Discutir como as } \\
\text { questões } \\
\text { multiculturais } \\
\text { perpassam a } \\
\text { formação oferecida } \\
\text { pelas três } \\
\text { principais } \\
\text { instituições que } \\
\text { oferecem o curso } \\
\text { de licenciatura em } \\
\text { música na cidade } \\
\text { do Rio de Janeiro. }\end{array}$ & $\begin{array}{l}\text { Constatou-se que, em } \\
\text { geral tais formandos } \\
\text { (as) reconhecem a } \\
\text { importância de uma } \\
\text { educação musical } \\
\text { multicultural, mas } \\
\text { não sentem que o seu } \\
\text { ensino superior os } \\
\text { (as) está preparando } \\
\text { para atuar na e com a } \\
\text { diversidade cultural } \\
\text { encontrada nas salas } \\
\text { de aula de educação } \\
\text { básica. }\end{array}$ \\
\hline
\end{tabular}




\begin{tabular}{|c|c|c|c|c|c|}
\hline 27 & $\begin{array}{c}\text { CASTRO, R. E.; } \\
\text { TEIXEIRA, M. } \\
\text { R. F. }\end{array}$ & $\begin{array}{l}\text { Música na educação: } \\
\text { uma possibilidade a } \\
\text { ser ampliada. }\end{array}$ & 2020 & $\begin{array}{l}\text { Verificar o uso da } \\
\text { música como } \\
\text { ferramenta } \\
\text { pedagógica na } \\
\text { educação básica. }\end{array}$ & $\begin{array}{l}\text { A música apesar de } \\
\text { mostrar um caráter } \\
\text { promissor na } \\
\text { educação, e embora } \\
\text { já permeie o sistema } \\
\text { educacional desde o } \\
\text { século passado, ainda } \\
\text { não é utilizada de } \\
\text { forma efetiva para } \\
\text { articular e promover } \\
\text { o ensino e a } \\
\text { aprendizagem } \\
\text { transdisciplinar de } \\
\text { modo eficaz, como } \\
\text { recurso pedagógico. }\end{array}$ \\
\hline 28 & NEVES, I. S. & $\begin{array}{l}\text { Narrativas orais } \\
\text { indígenas em sala de } \\
\text { aula: música, } \\
\text { interação social e } \\
\text { transformação } \\
\text { histórica }\end{array}$ & 2015 & $\begin{array}{l}\text { Analisar alguns } \\
\text { resultados do } \\
\text { projeto Crianças } \\
\text { Suruí-Aikewara: } \\
\text { entre a tradição e as } \\
\text { novas tecnologias. }\end{array}$ & $\begin{array}{l}\text { As narrativas orais } \\
\text { indígenas } \\
\text { vezes muitas } \\
\text { classificadas ramo } \\
\text { lendas, um gênero } \\
\text { menor da literatura, } \\
\text { ou como mitos, que } \\
\text { não merecem } \\
\text { credibilidade como } \\
\text { fontes históricas. } \\
\text { Frequentemente, } \\
\text { também são } \\
\text { entendidas apenas } \\
\text { como uma } \\
\text { manifestação da } \\
\text { palavra falada numa } \\
\text { perspectiva } \\
\text { homogênea de lingua } \\
\text { e não como um } \\
\text { complexo processo } \\
\text { de comunicação } \\
\text { verbal, que pode } \\
\text { envolver, os gestos, a } \\
\text { pintura, a voz, a } \\
\text { música. }\end{array}$ \\
\hline 29 & $\begin{array}{l}\text { REIS, J. G.; } \\
\text { DUARTE, P. }\end{array}$ & $\begin{array}{c}\text { O currículo, a } \\
\text { educação musical e } \\
\text { as realidades } \\
\text { individuais de cada } \\
\text { estudante: um ensaio } \\
\text { me defesa da } \\
\text { inclusão cultural no } \\
\text { ensino de música. }\end{array}$ & 2018 & $\begin{array}{l}\text { Discutir a } \\
\text { necessidade de se } \\
\text { valorizar os vários } \\
\text { gêneros musicais, } \\
\text { nomeadamente } \\
\text { aqueles que se } \\
\text { encontram } \\
\text { culturalmente mais } \\
\text { próximos dos } \\
\text { alunos, e promover } \\
\text { diferentes práticas } \\
\text { pedagógicas- } \\
\text { curriculares } \\
\text { associadas a esta } \\
\text { dimensão, }\end{array}$ & $\begin{array}{l}\text { Não existe uma } \\
\text { abordagem } \\
\text { pedagógica universal } \\
\text { que resulte em todos } \\
\text { os contextos culturais } \\
\text { e educacionais. Mas } \\
\text { uma abordagem } \\
\text { informal de ensino e } \\
\text { uma aprendizagem } \\
\text { musical característica } \\
\text { das músicas } \\
\text { populares, a par da } \\
\text { integração das } \\
\text { mesmas, não só um } \\
\text { reconhecimento das }\end{array}$ \\
\hline
\end{tabular}




\begin{tabular}{|c|c|c|c|c|c|}
\hline & & & & $\begin{array}{l}\text { potenciando uma } \\
\text { educação musical } \\
\text { mais inclusiva e } \\
\text { completa. }\end{array}$ & $\begin{array}{l}\text { vivências } \\
\text { experiências das } \\
\text { crianças e dos jovens } \\
\text { que não se } \\
\text { identificam com a } \\
\text { cultura dominante, } \\
\text { mas também na } \\
\text { transformação } \\
\text { daqueles contextos } \\
\text { em espaços livres, de } \\
\text { participação ativa e } \\
\text { crítica. }\end{array}$ \\
\hline 30 & $\begin{array}{l}\text { SOUZA, R. S.; } \\
\text { MONTI, E, M. } \\
\text { G. }\end{array}$ & $\begin{array}{c}\text { Um olhar } \\
\text { multicultural: } \\
\text { algumas } \\
\text { contribuições para a } \\
\text { atuação do professor } \\
\text { de música da } \\
\text { educação básica. }\end{array}$ & 2016 & $\begin{array}{l}\text { Dissertar que a } \\
\text { Educação Musical } \\
\text { deve respeitar a } \\
\text { diversidade } \\
\text { contribuir no } \\
\text { combate a todo tipo } \\
\text { de preconceitos. }\end{array}$ & $\begin{array}{lr}\text { A adoção de } & \text { um } \\
\text { currículo e } & \text { uma } \\
\text { didática multicultural } \\
\text { pode ajudar } \\
\text { diminuir } & \text { os } \\
\text { fenômenos } & \text { sociais } \\
\text { negativos, } & \text { ao } \\
\text { estimular } & \text { traços } \\
\text { culturais } & \text { entre } \\
\text { diferentes grupos. }\end{array}$ \\
\hline
\end{tabular}

Fonte: Elaborado pela autora (2020). 


\section{A Construção de um Currículo sob a Perspectiva da Multiculturalidade}

A intensificação dos processos de globalização acabou gerando um processo reverso de busca da identidade cultural por meio do debate em relação ao direito à diferença, transformando essa questão fundamental para compreender o papel do indivíduo na sociedade (REIS, 2014). Esse embate se dá também na educação, uma vez que, por meio dela, é possível transmitir e perpetuar a cultura. Assim, o conteúdo escolar é elaborado com base em uma seleção e uma reelaboração de conceitos culturais, para com isso, torna-los satisfatórios para serem repassados nas escolas (FELIPE; FRANÇA, 2014).

Esse processo de seleção cultural nas escolas leva à discussão de apenas uma parcela das experiências coletivas dos indivíduos, em geral, a parcela de conhecimentos, valores e atitudes, considerada a versão autorizada ou legitima da cultura (FELIPE; FRANÇA). Logo, ocorre a marginalização da cultura de diversos grupos sociais no contexto escolar e a substituição por conteúdos, da parcela hegemônica. Por isso é que, historicamente, a escola passou a desempenhar o papel de homogeneizar os valores aceitos e promover a assimilação cultural dos alunos.

Segundo Oliveira (2016), o desafio que se coloca na contemporaneidade é reconhecer a importância de utilizar o espaço escolar para dar voz aos grupos sociais oprimidos e reverter a situação. Moreira (2014) aponta que uma das medidas indicadas para dar vez às camadas populares e compreender o conceito de multiculturalismo e como ele é implementado nas propostas curriculares.

De acordo com Sacristán (1995 apud MOREIRA, 2014, p.36) é possível que a expressão 'currículo multicultural' revele-se enganosa, pois pode significar que uma cultura dominante possa assimilar outra minoritária ou seja utilizada como meio de tentar realizar o preconceito com relação às minorias que compõem a sociedade, ou seja uma educação que levaria em conta as diferenças culturais dos membros de uma sociedade. Outra possibilidade, ainda conforme Moreira (2014) é entendê-la como uma 'visão não etnocêntrica da cultura', e, com isso, elaborar uma educação calcada no pluralismo cultural.

Por isso, ao falar em educação multicultural, é preciso deixar claro o que isso significa e como esse multiculturalismo estará presente no currículo escolar. Para tentar compreender essa questão é necessário voltar ao conceito de globalização, avançar na direção do que é multiculturalismo e discutir como tudo isso 
se coloca na sociedade contemporânea (OLIVEIRA, 2016).

Para HEIN (2014) a luta pelo direito à diferença ocorre não apenas nas relações de poder entre países, mas também em uma sociedade que marginaliza certos grupos sociais em favor dos outros. É uma questão política que envolve novas concepções de democracia, com o reconhecimento e a valorização da diferença como educação básica para uma prática política democrática em todos os níveis. Mas também uma questão cultural, pois o direito à diferença engloba os conceitos de multiculturalismo e interculturalismo, a fim de explicar a diversidade cultural em uma sociedade globalizada.

Conforme Priore (2014, apud HEIN, 2014, p. 78), o termo "multiculturalismo" designa tanto um fato como uma política, colocada em funcionamento em níveis diferentes, visando à coexistência pacifica entre grupos étnicos e culturalmente diferentes. A política multiculturalista visa resistir à homogeneidade cultural, sobretudo quando esta afirma-se como única e legitima, reduzindo as outras culturas à sua dependência. Andrade (2013, apud Oliveira, 2016, p.3) aponta que “o multiculturalismo relaciona-se com as estratégias e políticas que são constituídas para lidar com os conflitos que existem em sociedades multiculturais. $\mathrm{O}$ termo 'multiculturalismo' abarca uma diversidade semântica, bem como diversidade de perspectivas, umas mais reacionárias e outras mais libertadoras e até as mais libertadoras. "Alguns teóricos consideram que o termo interculturalismo" seria o mais apropriado para fazer referência a uma cultura em interação.

Para Moreira (2014a), o prefixo "inter" da ideia de interação, troca ou solidariedade que deve haver na relação entre culturas diferentes. Reis (2014, p. 62) ressalta que "a perspectiva intercultural mais do que o reconhecimento e a valorização da diversidade cultural e das diferenças, [...], supõe a interrelaçao entre os diferentes grupos socioculturais, reconhecendo que nesse processo há um complexo campo de confrontos e de enfrentamentos que podem ser transpostos, não só, mas por uma dialogia da alteridade".

Nos Estados Unidos, os dois termos são tratados como sinônimos, pois os especialistas acreditam que ambos se referem à mesma coisa. A ideia de multicultural este ligada ao reconhecimento de diferenças culturais e à necessidade de respeitar essas diferenças em uma sociedade plural, ou seja, uma sociedade democrática, sem que isso signifique necessariamente a interligação ou uma conexão entre essas múltiplas culturas (REIS, 2014). Além disso, o 
multiculturalismo originou-se a partir de discussões, dentro do movimento social negro dos Estados Unidos, tendo personalidades como Martin Luther King e Malcom $X$ no centro dos debates (BASTOS, 2017). A ideia inicial era o reconhecimento dos direitos sociais dos negros, mas a discussão em torno do multiculturalismo, como luta pelo respeito às diferenças e pela igualdade dos direitos sociais, ampliou-se para outros grupos, como no caso dos indígenas, homossexuais e pessoas com deficiências físicas e mentais.

Vale ressaltar, conforme Bastos (2017), que todo esse questionamento partiu de movimentos e grupos sociais, e não de discussões acadêmicas. A academia só passou a considerar esse conceito relevante a partir da força que ele ganhou dentro da sociedade. De acordo com guerra, et al (2018), “o multiculturalismo tem sido revisitado nos debates atuais pela necessidade de promover a equidade educacional, valorizar as culturas dos alunos e colaborar para superar o insucesso escolar".

Malanchen (2015, p.59), afirma que "para os defensores do multiculturalismo, o que deve ser analisado e denunciado é como discriminações, relativas a questão de gênero, raça, etnia, classe e religião, afetam a construção do conhecimento, valores e identidades nas instituições escolares". Para Sacristán (2000, apud Crepaldi, 2015, p. 38145) "o multiculturalismo na escola nada mais é do que a inclusão de todos à educação, procurando atender aos interesses de todos, independentemente de etnias, deficiências, ou diferentes grupos minoritários, geralmente excluídos e marginalizados". Nesse sentido acredita-se que uma educação multicultural pode desenvolver a sensibilidade para a pluralidade de valores e culturas. Assim, ao seguir a perspectiva multicultural a escola assume o compromisso de se colocar a favor de um ensino de qualidade para toda a população, onde apresenta-se contrária à exclusão, à desigualdade e a todos os movimentos que se manifestam em oposição às práticas humanitárias e solidárias.

Malanchen (2015, p. 59) aponta que: “em meio a estas questões ganha cada dia mais espaço o currículo numa perspectiva multicultural", que deve ser "organizado com base nas múltiplas experiências existentes nas diferentes culturas, de uma maneira que os alunos consigam se reconhecer e valorizar a cultura do grupo social ao qual são integrantes e compreende e respeita a cultura do outro". Desse modo, o multiculturalismo, pensado em termos de currículo escolar, tende a enfatizar a valorização das subjetividades, a 
diversidade, a inclusão de minorias historicamente marginalizadas, as diferentes identidades dos sujeitos das práticas educativas, os discursos e seus significados de forma contextualizada.

Considerando que o currículo corresponde ao planejamento da instituição escolar na dimensão didático-pedagógica e expressa as experiências escolares que envolvem o conhecimento, esse documento precisa explicitar alguns elementos teóricometodológicos a fim de nortear as práticas pedagógicas.

De acordo com Paula (2016), os sistemas de ensino, assim como as instituições escolares, tem autonomia para definir os elementos que irão compor o currículo, conforme as necessidades e as especificadas das etapas ou modalidades de ensino nas quais serão desenvolvidas. Porém, segundo Libâneo (2004 apud Paula, 2016), há alguns elementos que não podem deixar de ser considerados, como a tendência ou concepção pedagógica, bem como seus fundamentos teóricometodológicos; a matriz curricular, sua organização e abordagem didáticopedagógica e os critérios, expectativas ou referencias de avaliação.

Sob a ótica da educação multicultural, propõem-se que "sejam elaborados currículos multiculturalmente orientados, nos quais sejam incluídos: valores, crenças, costumes e as diversas verdades da pluralidade de culturas existentes, rejeitando-se, dessa forma, o critério de maior ou menor fidedignidade das ideias à realidade natural e social" (MALANCHEN, 2015, p. 60).

Diante dessa proposta percebe-se que o currículo pode ir além dos conteúdos, propondo a reconstrução social, de modo a proporcionar mudanças. Nesse sentido o currículo pode ser considerado como uma ferramenta pedagógica transformadora, uma vez que por meio dele mudam-se caminhos, propõem-se rotas, atravessam-se barreiras, adquirindo conhecimento e estabelecendo um fazer pedagógico diário.

Para assegurar que os objetivos e as finalidades previstos no currículo sejam efetivados, o professor precisa elaborar e efetivar outra dimensão do planejamento: o plano de trabalho docente, o qual recebe diversas denominações como: planejamento didático, projeto de ensinoaprendizagem, planos de ensino, plano de ação docente etc. (PAULA, 2016).

O plano de trabalho docente é o instrumento orientador e organizador da prática pedagógica; ele possibilita ao professor prever antecipadamente suas ações em sala de aula, contribuindo para que estas sejam conscientes e seguras. Além disso, o plano expressa o desejo de aperfeiçoar a prática pedagógica e superar 
possíveis dificuldades, como índices de reprovação, pouca qualidade de ensino e de aprendizagem, insatisfação e desinteresse dos alunos (PAULA, 2016).

Essa prática permite perceber quão envolvido pode estar um professor no processo de ensino-aprendizagem e como ele pode questionar-se acerca do seu papel, e do trabalho que estão realizando e o tipo de cidadão que está formando. Corroborando com essa afirmativa, Silva (2010 apud Crepaldi, 2015, p. 38147), aponta que: “[...] é num tempo como esse que nós, educadores e educadoras (pós) críticos/as, nos vemos moralmente obrigados, mais do que nunca, a fazer perguntas cruciais, vitais, sobre nosso oficio e nosso papel, sobre nosso trabalho e nossa responsabilidade".

A escola é imprescindível para a transformação social. Uma educação de qualidade é o que pode gerar uma sociedade mais justa e igualitária, e com certeza os profissionais da educação se encontram aí, neste local, como grandes responsáveis por esta qualidade. Na atual conjuntura social, a sociedade exige uma demanda muito forte de profissionais capacitados que atuem em diversos espaços que envolvem práticas educativas e socioculturais (GOMES, 2015).

Essa responsabilidade social é tida como um desafio na atuação do pedagogo, porque durante a formação percebemos que se deixa uma lacuna que necessita de conceitos e conteúdo mais consistentes e aprofundados para uma atuação reflexiva que contribua significativamente com a situação imposta a esse profissional. Não somente ao pedagogo, mas a todos os profissionais da área educacional, é mister qualificar-se continuamente, para assegurar um ensino de qualidade e uma formação humana cidadã (GOMES, 2015).

Nesse contexto Ivericki (2018, p. 1151), ressalta que "pensar na formação de professores inicial e continuada para o respeito à diversidade cultural e o desafio a preconceitos tem disso o foco do multiculturalismo". É possível perceber a complexidade em ser professor em um país multicultural onde a diversidade é presente em sala de aula exige que o docente reveja sua prática constantemente.

O currículo multicultural pode se realizar, se completar e se concretizar na prática docente, na sala de aula, no espaço de aprendizagem, assim como na interação que ocorre entre o professor, o conteúdo e o educando. Segundo Reis (2014, p. 61), “é preciso um comprometimento pedagógico que traduza o multiculturalismo em processos de ensino-aprendizagem efetivamente coadunados com o combate às discriminações, aos estereótipos, às desigualdades ou a qualquer tipo de 
exclusão". Assim, entende-se que as condições desenvolvidas pelo professor dentro do ambiente escolar são de fundamental importância para que ele possa implementar a multiculturalidade em sua prática pedagógica.

Além das condições para que o processo de ensino-aprendizagem ocorra, o professor deve criar atividades ou tarefas pelas quais, pela mediação e pelos meios simbólicos, possa operacionalizar a internalização de conteúdos que fomentem o respeito à diversidade cultural. Portanto, o professor como agente desse processo deve proporcionar diferentes formas de compreensão e respeito, a fim de consolidar a educação multicultural (REIS, 2014).

Para Souza (2019, p. 19), “incluir nos conteúdos escolares outras formas de se pensar e fazer ciência, outras maneiras de leitura e sentido diante do mundo, e diferentes formas de vivenciar o cotidiano são caminhos que se abrem para o professor e a escola que pretendem praticar um currículo em ação multiculturalmente orientado". Desse modo, entende-se que a forma como o professor realiza as tarefas, as atividades e a mediação pode ser um ato de conservação do modelo dominante ou pode favorecer a reflexão ou mudança desse modelo. O currículo multicultural desenvolvido nesse contexto, pode representar um campo de lutas em torno de possíveis interpretações e significados.

\section{A Lei $n^{\circ}$ 11.645/2008 e a Inserção da Temática Indígena no Currículo Escolar}

O pensamento etnocêntrico esteve presente durante muitos anos em nossa sociedade de modo geral, particularmente nas escolas e nos currículos escolares percebeu-se a adoção de modelos tradicionais que supervalorizava a cultura determinada pela minoria, assumindo assim, uma posição manipuladora e massificadora.

Com o passar dos anos entendeu-se que era preciso considerar cada aluno como um sujeito portador de características socioculturais próprias e, portanto, resultantes de suas vivências. Desse modo, o processo educativo deveria oferecer alternativas e instrumentos para que os alunos tivessem consciência de si mesmos e dos outros. De acordo com Domingues; Cota (2014, p. 12), adotar uma educação sob a perspectiva da multiculturalidade “implica em tornar acessível aos alunos o conhecimento sobre as diferentes sociedades e atores sociais, descontruir discursos discriminatórios e dar aos estudantes uma compreensão de que somos constituídos como sujeitos na diversidade de experiências históricas com o "outro"”. 
Pensar numa educação sob a perspectiva multicultural não significa promover festas, trabalhar com manifestações folclóricas, lendas e mitos. Para além disso, deve-se ter em mente que no ambiente escolar estamos lidando com realidades distintas e culturas diversificadas.

Para eliminar o pensamento etnocêntrico presente em nossa sociedade o governo propôs o documento Parâmetros Curriculares Nacionais (PCNs, Brasil, 2000), com a proposta de temas transversais, incorporando a pluralidade cultural. Os denominados PCNs também buscam o fim do preconceito contra as minorias étnicas em nosso país e aponta alguns princípios norteadores para a ação docente.

Com a aprovação da Lei n. 10.639, em 2003, que altera a última Lei de Diretrizes de Bases da Educação Nacional, de 1996, inclui-se no cenário educacional brasileiro os estudos de História da África e da Cultura Afro-Brasileira, a serem ministrados em todos os estabelecimentos de ensino fundamental e médio das redes pública e privada, obrigatoriamente contemplados no currículo escolar, com especial atenção nas áreas de História, Literatura e Educação Artística (BRASIL, 2005).
Na Lei 10.639/03 (BRASIL, 2003) exige um repensar das relações étnicoraciais, dos conteúdos pedagógicos e dos procedimentos de ensino na perspectiva de uma ampliação do foco dos currículos escolares para a diversidade cultural, racial, social e econômica brasileira.

A partir da lei, tornou-se obrigatória a inclusão nos currículos dos estabelecimentos de ensino fundamental e médio de conteúdos relacionados à história da África e à cultura afro-brasileira, até então quase inexistentes ou, quando apresentados, com visões distorcidas, além de buscar corrigir versões desvirtuadas no processo didático-pedagógico, bem como inserir as histórias da população afrodescendente de maneira mais ampliada dentro do contexto educacional.

A referida lei é resultante de inúmeras reivindicações e da luta travada por diversos setores da sociedade brasileira pela reparação dos erros cometidos em mais de dois séculos de escravidão de africanos e afrodescendentes.

Entendendo que a lei por si só não daria conta de atender às necessidades apontadas pelo Plano Nacional de Promoção da Igualdade Racial, no ano de 2004 foi aprovada pelo Conselho Nacional de Educação a Resolução n. I, que instituiu as Diretrizes Curriculares Nacionais para a educação das relações étnico-raciais e para 
o ensino de História e Cultura AfroBrasileira e Africana.

Essa resolução enfatiza a necessidade de se reconhecer e valorizar "a identidade, a história e a cultura dos afrobrasileiros, bem como a garantia de reconhecimento e igualdade de valorização das raízes africanas da nação brasileira, ao lado das indígenas, europeias, asiáticas" (Brasil, 2004). Com isso, tanto a lei $10.639 / 03$ quanto as formas de regulamentação estão diretamente vinculadas à garantia do direito à educação e ao respeito da diferença.

Com o intuito de trazer ao conhecimento da população brasileira a importância dos povos indígenas, em 10 de março de 2008 foi aprovada a Lei n. 11.645 que modifica a Lei 10.639/2003. Esta nova Lei inclui as questões indígenas, onde, até então, era previsto apenas aos afrodescendentes. Nesse sentido, prevê incluir no currículo da rede de ensino a obrigatoriedade da temática "História e cultura Afro-brasileira e Indígena" (BRASIL, 2008).

Machado; Leon (2019, p. 3), afirmam que "essa lei faz com que as questões indígenas e afro-brasileiras deixem de fazer parte apenas da história de formação do nosso país e passem a fazer parte do nosso presente." Tal lei abrange o conhecimento cultural das diferentes etnias presentes no Brasil. Essas são vitórias das lutas dos movimentos sociais, que lutam pelo reconhecimento social de sua cultura e a importância que tem na formação sociocultural do país.

Desse modo, entende-se que a implementação da referida lei se trata de uma perspectiva de intervenção na história e nos processos educativos que nos possibilita compreender que o respeito à diferença não implica a transformação do outro no que somos, tampouco que devemos ser tal qual o outro é. Ao contrário, trata-se de compreender e aceitar que o outro é o que não somos. Trata-se de evidenciar, na identidade nacional, nossas raízes, reconhecendo a presença e respeitando as contribuições culturais trazidas por diferentes povos e etnias que constituem a identidade do povo brasileiro. Eis aí a riqueza dessa lei: ela exige um novo olhar sobre nós mesmos, sobre o outro e sobre as nossas diferenças.

Assim, com a inserção da temática indígena nas escolas tenciona-se "contribuir com a eliminação dos preconceitos, cabendo aos professores não indígenas sensibilizarem-se com a questão indígena e apropriarem-se da temática de maneira satisfatória" (BUSOLLI; LAROQUE, 2018, p, 40). 
A obrigatoriedade da inclusão da história e cultura indígena nos currículos da Educação Básica trata-se de uma lei, com repercussões na base pedagógica, inclusive no que tange a formação de professores. Assim, para que uma história multiculturalista seja efetiva, deverá ter como maior propulsor os professores, os disseminadores do conhecimento no ambiente escolar que podem contribuir para romper com o preconceito, e propiciar atitudes de respeito às diversas culturas. Portanto, o docente para atender esses anseios deve ser um pesquisador/professor, desprovido de preconceitos, trabalhando-as de forma concisa, promovendo nos alunos um olhar novo olhar a respeito das culturas existentes em nosso país.

Como sabemos, nossas identidades pessoais e grupais são construídas tomando por base o modelo cultural determinado pela sociedade que pertencemos. É por meio desse modelo que essa mesma sociedade nos enquadra em papéis e funções sociais. A identidade nacional, nesse sentido, é parte da construção desse modelo, sendo diferente da totalidade de nossa cultura.

Cada povo e cada nação carrega consigo um conjunto de traços que são produto de sua construção histórica. Nele estão presentes diferenças que nos destacam de outros povos. Entre essas diferenças, encontra-se a forma específica como construímos a vida política, social, econômica, jurídica e territorial. A cultura, e, consequentemente, nossa identidade, é produto da interação que estabelecemos com nossos semelhantes e dos hábitos, costumes e tradições, reforçados ou descartados por nós no cotidiano dessas relações. Vale destacar que, em nossa constituição como nação, estão presentes aspectos de ordem biológica, geográfica e cultural (BUSOLLI; LAROQUE, 2018).

Assim, é preciso considerar que a implementação da lei em questão depende também do enfrentamento de outras situações que são produto do pensamento e das práticas etnocêntricas vividas ao longo de séculos pela sociedade brasileira.

\section{A Educação Musical Inclusiva e o Respeito às Diferenças: uma Possibilidade para o Ensino das Músicas Indígenas}

A música está tão presente em nosso cotidiano, que nem sempre paramos para pensar nas influências que ela exerce sobre nós, ou na importância que ela tem na nossa vida, apesar de termos, quase sempre, músicas que gostamos de ouvir, cantores preferidos, bandas que seguimos pelas diferentes mídias. De acordo com Castro; Teixeira (2020, p. 6), "desde a antiguidade a música tem uma posição de destaque em todo mundo e no Brasil a música já foi 
disciplina obrigatória em currículos básicos".

No que se refere especificamente à educação musical em âmbito nacional, esta teve como marco oficial a vinda dos jesuítas para o país, os quais utilizaram a música como recurso pedagógico para educação e a conversão dos diferentes grupos indígenas que aqui viviam. Com base nos modelos europeus, o ensino de música da época colonial tinha por base os padrões técnicos e estéticos dos conservatórios tradicionais, o que perdurou por muito tempo no país (CASTRO; TEIXEIRA, 2020).

Durante um extenso período, a educação musical teve esse caráter tecnicista, sem uma identidade nacional. Somente nas primeiras décadas do século $\mathrm{XX}$, por meio de pesquisas e ações de diferentes educadores e músicos, começouse a valorizar o cancioneiro popular e a música instrumental, por meio da instituição de algumas escolas e da organização da formação docente (BORGES; RICHIT, 2020).

O projeto Villa-Lobos, que por meio do canto orfeônico objetivou levar a música a um grande número de pessoas, representou um grande marco na nossa história e, apesar do seu caráter cívico, foi significativo na difusão dos valores culturais (FONTERRADA, 2008, APUD BORGES; RICHIT, 2020).
No ano de 1971, “a música passou a integrar a disciplina de Educação Artística" (BRASIL, 1971), no entanto, seu ensino enfraqueceu uma vez que "os professores que atuavam nessa disciplina recebiam uma formação artística mais generalista e precisavam dar conta de contemplar em suas aulas as diversas linguagens das artes" (GALIZIA, 2011 apud BORGES; RICHIT, 2020).

Acerca desse momento Castro; Teixeira (2020, p. 6) esclarecem que "o desaparecimento gradativo da música na escola, ecoa, sob alguns aspectos, a falta de valoração progressiva deste conhecimento pela sociedade".

Apesar do enfraquecimento do ensino de música nas escolas brasileiras, no ano 2008, através da Lei n. 11.769, a música tornou-se componente curricular obrigatório nas escolas, que teriam que se adaptar à nova norma até o ano de 2011 (BRASIL, 2008). Herbetta (2016, p. 39) aponta que "dentre outras questões, a lei não determina claramente se a educação deve ser uma disciplina independente ou se deve estar integrada na educação artística" e assim, o ensino de música permaneceu afastado dos currículos escolares ou era desenvolvido de forma fragmentada.

Por ser entendida apenas como entretenimento ou uma disciplina que não necessitava ser desenvolvida a partir de seus 
fundamentos teóricos, o que acabava por esvaziar seu valor como área de conhecimento. Um dos motivos para essa falha consistia na falta de profissionais que possuíssem qualificação ou habilitação necessária para atuar nessa área (GUIMARÃES, 2017).

Atualmente o ensino de música voltou a ser obrigatório no Brasil através da Lei 13.278/2016, na qual a música continua presente na disciplina de Artes, no entanto, como uma das linguagens artísticas que constituem o seu currículo. Ao regulamentar o ensino de Música na Educação Básica, essa Lei estabelece o prazo de no máximo cinco anos para que as mudanças necessárias sejam realizadas e obtermos o número necessário de professores para a efetivação do ensino de artes visuais, dança, música e o teatro como componentes curriculares (BRASIL, 2016).

Além desse documento de caráter normativo, temos a Base Nacional Comum Curricular (BNCC) que define o conjunto orgânico e progressivo de aprendizagens essenciais que todos os alunos devem desenvolver ao longo das etapas e modalidades da Educação Básica, conforme definido na Lei de Diretrizes e Bases (LDB 9.934/96) e acentuado no Plano Nacional da
Educação (PNE 2014-2024) (BRASIL, 2018).

Na BNCC estão contidas diretrizes para elaboração de currículos escolares na tentativa de superar as fragmentações históricas nos conteúdos ensinados nas diferentes etapas da educação básica.

Está pautada em dez competências gerais, as quais devem reger as três etapas da educação básica, em que, alinhado ao fazer pedagógico escolar, os estudantes possam construir seus conhecimentos e desenvolver suas habilidades voltadas para atitudes e valores. Além disso, a BNCC estabelece cinco campos de experiências, quais sejam: o eu, o outro e o nós; corpo, gestos e movimentos; traços, sons, cores e formas; escuta, fala, pensamento e imaginação e espaços, tempos, quantidades, relações e transformações (BRASIL, 2018).

O Ensino Fundamental está organizado em cinco áreas do conhecimento, e o componente curricular Arte está disposto na área de Linguagens.

A finalidade dessa área é possibilitar aos estudantes participar de práticas de linguagem diversificadas, que lhes permitam ampliar suas capacidades expressivas em manifestações artísticas, corporais e linguísticas, e também seus conhecimentos sobre essas linguagens. 
Quadro 03 - Habilidades para Arte no Ensino Fundamental - Música

\begin{tabular}{|c|c|}
\hline \multirow{4}{*}{ Anos Iniciais } & $\begin{array}{l}\text { (EF15AR13) Identificar e apreciar criticamente diversas formas e gêneros de } \\
\text { expressão musical, reconhecendo e analisando os usos e as funções da música em } \\
\text { diversos contextos de circulacão, em especial, aqueles da vida cotidiana. }\end{array}$ \\
\hline & $\begin{array}{l}\text { (EF15AR14) Perceber e explorar os elementos constitutivos da música (altura, } \\
\text { intensidade, timbre, melodia, ritmo etc.), por meio de jogos, brincadeiras, canções } \\
\text { e práticas diversas de composição/criação, execução e apreciação musical. }\end{array}$ \\
\hline & $\begin{array}{l}\text { (EF15AR15) Explorar fontes sonoras diversas, como as existentes no próprio } \\
\text { corpo (palmas, voz, percussão corporal), na natureza e em objetos cotidianos, } \\
\text { reconhecendo os elementos constitutivos da música e as características de } \\
\text { instrumentos musicais variados. }\end{array}$ \\
\hline & $\begin{array}{l}\text { (representação gráfica de sons, partituras criativas etc.), bem como procedimentos } \\
\text { e técnicas de registro em áudio e audiovisual, e reconhecer a notação musical } \\
\text { convencional. }\end{array}$ \\
\hline \multirow{4}{*}{ Anos Finais } & $\begin{array}{l}\text { (EF69AR16) Analisar criticamente, por meio da apreciação musical, usos e } \\
\text { funções da música em seus contextos de produção e circulação, relacionando as } \\
\text { práticas musicais às diferentes dimensões da vida social, cultural, política, } \\
\text { histórica, econômica, estética e ética. }\end{array}$ \\
\hline & $\begin{array}{l}\text { EF69AR19) Identificar e analisar diferentes estilos musicais, contextualizando-os } \\
\text { no tempo e no espaço, de modo a aprimorar a capacidade de apreciação da estética } \\
\text { musical. }\end{array}$ \\
\hline & $\begin{array}{l}\text { (EF69AR21) Explorar e analisar fontes e materiais sonoros em práticas de } \\
\text { composição/criação, execução e apreciação musical, reconhecendo timbres e } \\
\text { características de instrumentos musicais diversos. }\end{array}$ \\
\hline & $\begin{array}{l}\text { EF69AR23) Explorar e criar improvisações, composições, arranjos, jingles, } \\
\text { trilhas sonoras, entre outros, utilizando vozes, sons corporais e/ou instrumentos } \\
\text { acústicos ou eletrônicos, convencionais ou não convencionais. }\end{array}$ \\
\hline
\end{tabular}

Fonte: Adaptado da BNCC (BRASIL, 2018).

Entre as competências gerais da BNCC, encontramos três que podem ser pensadas de forma abrangente e inclusiva para a inserção da música na escola: "valorizar e fruir as diversas manifestações artísticas e culturais, das locais às mundiais, e participar de práticas diversificadas da produção artístico-cultura; utilizar diferentes linguagens: verbal, corporal, visual, sonora e digital; valorizar a diversidade de saberes e vivências culturais" (BRASIL, 2018).

Diante dessas competências apontadas da BNCC percebe-se que além de compreender como a música é vista e valorizada na sociedade em que vivemos, o trabalho com música também possibilita ampliar a visão de mundo e o conhecimento das diferentes manifestações culturais, ressaltando com isso uma educação musical multicultural que ao ser posta em prática "buscará rejeitar visões tradicionais, reducionistas, hegemônicas e preconceituosas que afirmam que apenas certas manifestações musicais podem, realmente, ser classificadas com Música, ou que algumas musicalidades são superiores do que outras" (SOUSA; MONTI, p. 75).

Nesse contexto, cabe refletir como as músicas indígenas podem ser inseridas 
nas aulas de educação musical, partindo do pressuposto de que ao reconhecermos a multiculturalidade da sociedade brasileira, compreendemos então a diversidade étnica e cultural dos diferentes grupos sociais que a compõem.

Almeida; Pucci (2014, p. 5) sugerem que a inserção das músicas indígenas nas escolas devem ser feitas "de forma cuidadosa e bastante criteriosa", pois ressaltam que “em geral, as músicas indígenas quando apresentadas em sala de aula, fazem parte apenas da comemoração do Dia do Índio, sem uma preocupação de aproximar o aluno da música indígena propriamente dita e de seus contextos culturais".

Desse modo, se faz necessário apresentar para os alunos as especificidades do repertorio indígena, mostrando que este para muitas tribos está ligado aos rituais religiosos, rituais de passagem e à dança. Neves (2015) destaca que uma característica interessante das sociedades indígenas é que a arte de contar histórias é considerada muito especial e a narração das mesmas possui uma cadência musical, usando timbres de vozes distintos, pausas expressivas, ficando a narração muito próxima do canto.

É importante apresentar que as principais características da música indígena são o timbre anasalado, característica que é encontrada também na música brasileira, influenciando nosso jeito de cantar em um timbre nasal; o uso de instrumentos de percussão variados, como chocalhos, maracás, tambores, paus-dechuva, além de instrumentos de sopro, como flautas e zunidores; a música indígena deu origem a danças, como a catira, dança comum em regiões centrais do país, na qual os batimentos de pés e mãos são fortes traços da cultura indígena (NEVES, 2015).

Os instrumentos musicais indígenas são extraídos da floresta (sementes, madeiras, pedras, ovos, ossos, chifres e cascos de animais) e têm a finalidade de reproduzir os sons mágicos da mata. $\mathrm{O}$ índio compõe, toca, canta e dança em harmonia com a natureza. Possuidores de uma música própria, com o ritmo peculiar, tudo para os índios se encontra com a música, dança e poesia: o nascimento e a morte, guerras e festas, caça e amor, religião e vida (NEVES, 2015).

Fragoso (2015, p. 25) afirma que "o educador que inclui estas questões na abordagem de canções de outras culturas e mesmo da sua própria, permite que a música fale, mais que de si mesma (enquanto fenômeno físico), de nações, de povos, de pessoas, de indivíduo."

Desse modo, entende-se que a educação musical deve abranger os diferentes mundos musicais de uma cultura, 
seus discursos e significados, como uma porta de acesso ao conhecimento, à aceitação e compreensão de outros modos de ser e viver, entre eles, diferentes maneiras de utilizar e vivenciar a música.

Nas palavras de Elliot (2018, p. 28), “a educação musical também pode ter o potencial de mudar atitudes e comportamentos preconceituosos", o que está diretamente relacionado aos princípios da multiculturalidade em todas as suas instâncias. Sendo o multiculturalismo um movimento que respeita e valoriza a diversidade, que entende a diferença como algo positivo, é essencial que se busque ações mais inclusivas também no campo das artes, entendendo as influências que essa esfera do conhecimento gera e recebe da sociedade como um todo (PENNA, 2015).

Considerando que o multiculturalismo trata do reconhecimento da pluralidade cultural em sociedades cada vez menos homogêneas, "contribuindo para a formação de cidadãos tolerantes e democráticos" (PENNA, 2015, p. 87), acredita-se que abordagem da música, baseada no contexto sociocultural que a envolve, é de fundamental importância para o aprimoramento crítico-musical dos alunos, pois desenvolve a sensibilidade, a capacidade de compreensão do mundo que os cerca, a criação, bem como as experiências estéticas, a fruição, o prazer artístico.

Assim, conhecer outras culturas musicais, entender os processos de criação, os instrumentos musicais, pode facilitar a compreensão de nossa própria cultura.

Dessa forma, a escola torna-se o veículo para a humanização dos sentidos, tal como a educação musical. Cabe a ela disseminar o patrimônio musical edificado em diferentes tempos e contextos sociais ainda presentes na história e no padrão do que se ouve, canta e consome no Brasil (ELLIOT, 2018).

Em uma perspectiva multicultural, cabe aos educadores musicais compreender as diferenças entre o universal e o particular, percebendo onde as conexões acontecem, por mais distantes que pareçam, contribuindo, assim, na formação individual do aluno e na ampliação das perspectivas do ambiente escolar, visando um espaço consciente de cidadania de todas as raças, gêneros e padrões culturais.

\section{CONCLUSÃO}


Para uma sociedade se constituir de maneira bem sucedida, ela deve favorecer, em todas as áreas da convivência humana, o respeito à diversidade que a compõe. Um país só alcança seu pleno desenvolvimento, se garantir a todos cidadãos as condições para uma vida digna, de qualidade física, psicológica, social e econômica.

Nesse cenário, um papel fundamental é exercido pela educação, que tem o comprometimento de proporcionar a todos os cidadãos acesso ao conhecimento e a capacidade de desenvolvimento de suas competências.

Assim, o efetivo exercício da cidadania se daria pela utilização de conhecimento historicamente produzido pela humanidade, apreendido no ambiente escolar. Para que cada ação pedagógica seja resultado de um processo de aprendizagem para o aluno, a escola deve organizar os conteúdos curriculares de forma que contribua para a sua formação enquanto agentes sociais.

Diante do estudo, ora apresentado acredita-se que é possível adotar um currículo que proporcione a todos os alunos as mesmas oportunidades e direitos, independentemente das diferenças sociais, culturais e pessoais. No entanto, deve-se ter ciência de que um currículo flexível não se constrói deslocado da realidade concreta, mas, sim, dentro de um espaço capaz de favorecer o questionamento, e não apenas a reprodução da ordem vigente.

Desse modo percebe-se a importância em fomentar a construção de um currículo multicultural tendo em vista que essa perspectiva exige um novo olhar sobre nós mesmos, sobre o outro e sobre nossas diferenças.

Trata-se de evidenciar, na identidade nacional, nossas raízes, reconhecendo a presença e respeitando as contribuições culturais trazidas por diferentes povos e etnias que constituem a identidade do povo brasileiro. A educação, nesse propósito, busca eliminar preconceitos e discriminações na busca de um mundo menos opressivo, desigual e injusto e que se propõe compreender o processo de construção das diferenças e das desigualdades, ainda que estas sejam complexas e conflituosas

A adaptação curricular sob a perspectiva multicultural não é uma resposta automática à identificação de determinadas necessidades educativas especiais. Trata-se, na verdade, de um processo que deve ser pensado e programado seguindo uma ordem a qual corresponde à organização do trabalho cooperativo baseado no currículo regular.

Por isso se faz necessário formar professores para que esses sejam capazes de articular uma educação multicultural que 
estimule o prazer, para instaurar a presença

física e emocional de todos os envolvidos, possibilitar a participação efetiva e assim, então, estimular a produção de conhecimentos gratificantes em nível geral e pessoal. Isso pode acontecer se no processo educativo o professor se transformar em educador que torne possível

\section{REFERÊNCIAS}

ALMEIDA, B.; PUCCI, M. Há espaço para as músicas indígenas em um Brasil multicultural? - a inserção do repertorio indígena na educação musical. VIII Encontro Regional Norte da ABEM Associação Brasileira de Educação Musical. Educação musical: formação humana, ética e produção de conhecimento. Rio Branco, 25 a 27u de novembro de 2014.

ALMEIDA NETO, A. S. Ensino de História indígena: currículo, identidade e diferença. Patrimônio e memória. São Paulo, Unesp, v. 10, n. 2, p. 218-234, julho-dezembro, 2014.

. A história indígena a ser ensinada nos currículos oficiais brasileiros. Atos de Pesquisa em Educação. Blumenau, v. 10, n. 1, p. 100-122, jan./abr., 2015.

AMÉRICO, M. C. Formação de professores para a implementação da Lei 10.639/2003: o ensino da História e cultura afro-brasileira e indígena no currículo escolar. POIÉSIS - Revista do Programa de Pós-Graduação em Educação Mestrado - Universidade do Sul de Santa Catarina. Unisul, Tubarão, v. 8, n. 14, p. 515-534, jul./dez., 2014. aos alunos habitarem num espaço de construção do sujeito, no qual sejam articuladas estratégias dinâmicas de aprendizado individual que favoreçam a identidade, mas também observem as estratégias coletivas, com foco no diálogo, nas relações sociais, e principalmente no respeito à diversidade.

BASTOS, M. J. Multiculturalismo e Educação. Revista Científica

Multidisciplinar

Núcleo do Conhecimento. Ano 02, Ed.

01, Vol. 14, pp. 110-118. Janeiro de 2017.

BERNSTEIN, A. A relação intima entre currículo e cultura. Educação Pública, 13 set 2016. Disponível em:https://educacaopublica.cederj.edu.br/a rtigos/16/19/a-relao-ntima-entre-curriculoe-cultura. Acesso em: 25 de maio de 2020.

BORGES, A. S.; RICHIT, A. Cad.

Pesqui., São Paulo, v. 50, n. 176, p. 555574, abr./jun. 2020.

BRASIL. Ministério da educação/secretaria de educação fundamental. Parâmetros Curriculares Nacionais: Apresentação dos Temas Transversais: Ética. Rio de Janeiro, DP\&A, 2000.

\section{Lei n⿳10639 de 9 de janeiro de}

2003. Diretrizes Curriculares Nacionais para a Educação das Relações Étnicos Raciais e para o Ensino de História e Cultura Afro-Brasileira e Africana. Ministério da Educação. MEC/SECAD. 2005.

. Lei 11.645/08 de 10 de março de 2008. Diário Oficial da União, Poder Executivo, Brasília-DF. Disponível em: < http://www.planalto.gov.br/ccivil_03/_ato2 
007-2010/2008/lei/111645.htm>. Acesso em: 22 de maio de 2020.

. Base Nacional Comum Curricular (BNCC). Educação é a Base. Brasília, MEC/CONSED/UNDIME, 2018.

Disponível em:

<http://basenacionalcomum.mec.gov.br/ab ase/> Acesso em 01 de maio de 2020.

\section{Lei n. 5.692, de 11 de agosto de}

1971. Fixa Diretrizes e Bases para o ensino de $1^{\circ}$ e $2^{\circ}$ graus, e dá outras providências. Presidência da República. Casa Civil.

Subchefia para Assuntos Jurídicos. 1971.

. Lei n. 13.278, de 2 de maio de

2016. Altera o $\S 6^{\circ}$ do art. 26 da Lei n. 9.394, de 20 de dezembro de 1996, que fixa as diretrizes e bases da educação nacional, referente ao ensino de Arte. Presidência da República. Casa Civil. Subchefia para Assuntos Jurídicos. 2016.

BRIGHENTI, C. A. Decolonialidade, ensino e povos indígenas: uma reflexão sobre a lei n. 11.645. XXVIII Simpósio Nacional de História - Lugares dos historiadores: velhos e novos desafios. Florianopólis - SC, 27 a 3 de julho de 2015.

BUSSOLI, J.; LAROQUE, L. F. S. A lei $11.645 / 2008$ e os indígenas nos livros didáticos de História do ensino médio. Revista Tranversos. Rio de Janeiro, n. 13, mai-ago., 2018.

CASTRO, R. E.; TEIXEIRA, M. R. F. Música na educação: uma possibilidade a ser ampliada no cenário nacional.

Research, Society and Devehopment, v. 9, n. 7, e604974082, 2020.

CHICARINO, T. Diversidade cultural. Pearson Education do Brasil, São Paulo, 2017.

CREPALDI, E. M. F. Currículo e multiculturalismo: perspectivas para consciencialização das diferenças na escola. Educere XII - Congresso Nacional de Educação: Formação de Professores, Complexidade e trabalho docente. PUCPR, Curitiba: Paraná, 26 a 29 de outubro de 2015.

DOMINGUES, M. P. B. História indígena escolar: discursos em circulação. Educação Básica. Revista EBR, v. 2, n. 1, 2016.

DOMINGUES, M. P. B.; COTA, F. S. A diferença na sala de aula: reflexões sobre a história indígena escolar e a história de educação inclusiva. Revista do LhistaLaboratório de Ensino de História e Educação. n. 1, v. 1, julho/dezembro, 2014.

ELLIOT, D. J. Conceitos chave em educação musical multicultural. In: NASCIMENTO, M. A. T.; STERVINOU, A. A. M. Ensino e aprendizagem musicais no mundo: formação, diversidade e currículo com ênfase na formação humana. Sobral: Sobral, p. 2139, 2018.

FELIPE, D. A.; FRANÇA, F. F. A diversidade na educação escolar: $o$ currículo cp,p artefato cultural, Atos de Pesquisa - PPGE/ME, v. 9, n. 1, p. 49-63, jan./abr., 2014.

FERREIRA, B. Decolonizando a escola: em busca de novas práticas. Avá Revista de Antropologia. v. 33, Universidade Nacional de Misiones, 2018.

FIGUEIREDO, S. L. F.; MEURER, R. P. Educação musical no currículo escolar: uma análise dos impactos da lei n. 11.769/2008. Opus, v. 22, n. 2, p. 515-542, dez. 2016.

FRAGOSO, D. Os saberes do Xeramoi na aula de música: uma conversa sobre música Guarani e educação musical. IA Instituto de Artes. VIII Encontro de Educação Musical da Unicamp - EEMU, "Música além da pauta: a educação 
musical em diálogos com diferentes saberes". São Paulo: Campinas. 13 a 16 de abril de 2015.

FRIGE, A. A. C. et. al. A importância de um currículo multicultural nas aulas de educação física. Revista Gestão Universitária. v. 6, 2016.

GOMES, J. Projeto Integrador. Jess Pedagogia, 2015. Disponível em:http://jesspedagogia.blogspat.com.br/2 015/09/persperctivas-do-pedagogo-edapedagoga.html. Acesso em: 25 de maio de 2020.

GUERRA, M. G. G. V. et al. Por um currículo plural na perspectiva do multiculturalismo. Dialogia, n. 30, p. 157168, set./dez., 2018.

GUIMARÃES, P. V. Educação e Música. Pensar a Educação em Revista.

Curitiba/Belo Horizonte, v. 3, n. 2, p. 3-24, abr./jun., 2017.

HERBETIA. A. Entre a cantoria e a sala de aula: reflexões sobre o papel da música em novas matrizes curriculares de escolas Timbira. Espaço Ameríndio. Porto Alegre, v. 10, n. 1, p. 34-60, jan./jun., 2016.

IVENICKI, A. Multiculturalismo e formação de professores: dimensões, possibilidades e desafios na contemporaneidade. Ensaio: Aval, Pol. Públ. Educ., Rio de Janeiro, v. 26, n. 100, p. 1151-1167, jul./set., 2018.

MACHADO, C. B.; LEON, A. D. O movimento indígena e a educação escolar. RELACULT - Revista Latino-Americana de Estudos em Cultural e Sociedade. V, 05, ed. especial, abr. artigo n. 1200, 2019.

MALANCHEN, J. Pedagogia históricocrítica e saber objetivo versus multiculturalismo e o relativismo no debate curricular. Atual germinal: Marxismo e educação em debate, Salvador, v. 7, n. 1, p. 58-67, jun., 2015.

MOREIRA, A. F. B. (org.) Currículo: questões atuais. Campinas: Papirus, 2014. . Antônio Flávio Barbosa

Moreira, pesquisador em currículo. Belo Horizonte: Autêntica, 2014a.

NASCIMENTO, R. G. Escola como local das culturas: o que dizem os índios sobre escola e currículo. R. Educ. Publ. Cuiabá, v. 26, n. 62/1, p. 373-389, maio/ago. 2017.

NEVES, I. S. Narrativas orais indígenas em sala de aula: música, interação social e transformação histórica. Leitura, Teoria \& Práticas. Campinas, São Paulo, v. 33, n. 64, p. 129-143, 2015.

OLIVEIRA, A. G. Indagações sobre um currículo: desenvolvimento humano, multiculturalismo e diversidade cultural.

Rev. Int. Investig. Cienc. Soc., v. 12, n. 1, Asunción July, 2016.

PAULA, D. H. L. Currículo na escola e currículo da escola: reflexões e proposições. Curitiba: Intersaberes, 2016.

PENNA, M. Música (s) e seu ensino. 2 ed. rev. e ampl. Porto Alegre: Sulina, 2015. REIS, D. A. Currículo multi/intercultural no contexto escolar: implicações para a prática docente. Revista Amazônica de Ensino de Ciências. Manaus, v. 7, n. 14, p. 58-71, jul./dez., 2014.

REIS, J. G.; DUARTE, P. O currículo, a educação musical e as realidades individuais de cada estudante: um ensaio em defesa da inclusão cultural no ensino de música. Revista da Abem, v. 26, n. 41, p. 5-20, jul./dez., 2018.

SANTIAGO, R.; IVENICKI, A. Multiculturalismo na formação de professores de música: o caso de três instituições de ensino superior da cidade 
do Rio de Janeiro. Opus, [s.1.], v. 22, n. 1, p. 211-236, jun. 2016.

. Diversidade musical e formação de professores: Qual música forma o (a) professor (a) de música? Rev. FAEEBA. Ed. e Contemp. Salvador, v. 26, n. 48, p. 187-204, jan./abr., 2017.

SILVA, E. Os povos indígenas e o ensino: possibilidades, desafios e impasses a partir da Lei 11.645/2008. In: FERREIRA, G. G.; SILVA, E. H.; BARBALHO, J. H. S. (Orgs.) Educação e diversidade: um diálogo necessário na Educação. Maceió. EDUFAL, p. 161-180, 2015.
SILVA, M. P. Experiências músicas no espaço escolar: narrativas de jovens indígenas. Rev. FAEEBA - Ed e

Contemp. Salvador, v. 26, n. 48, p. 139150, jan./abr., 2017.

SOUZA, C. G. Projeto Sagrada natureza: currículo em ação - uma experiência multicultural na aplicação da lei 11.645/2008. RevistAleph. Número especial, ano XV, 2019.

SOUZA, R. S.; MONTI, E. M. G. Um olhar multicultural: algumas contribuições para a atuação do professor de música da educação básica. Revista Travessias. v. 10, n. 01, 26 ed. 2016. 


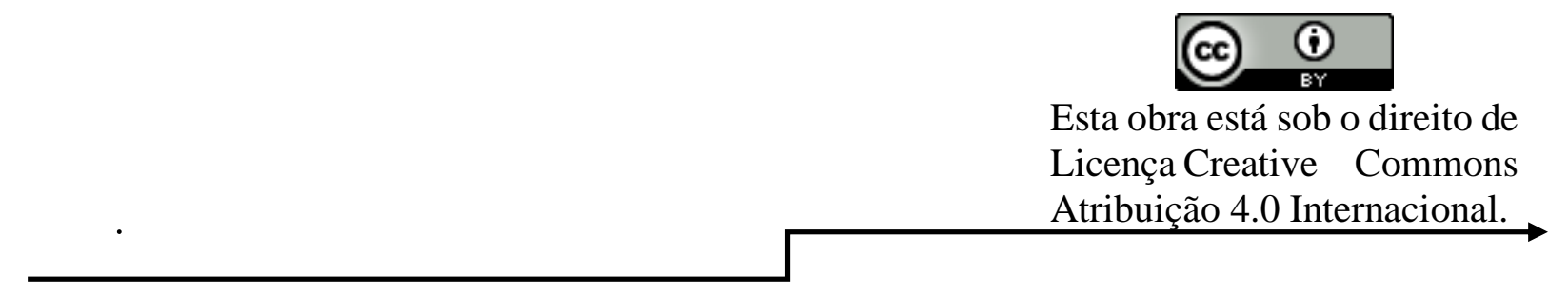

\title{
O YOUTUBE COMO FONTE DE PESQUISA NA ATUAÇÃO DO PSICÓLOGO ESCOLAR FRENTE AS METAMORFOSES NO ENSINO SUPERIOR
}

\author{
Eliane Reis Neves da Silva ${ }^{1}$ \\ Andrea Marques Vanderlei Fregadolli ${ }^{2}$ \\ Betijane Soares de Barros ${ }^{3}$ \\ Maria José Soares Ribeiro ${ }^{4}$ \\ Maria Isabel da Silva Martins 5 \\ Luciano Canuto Jacinto ${ }^{6}$
}

\section{RESUMO}

Introdução: a perspectiva do multiculturalismo surge como uma ideologia que defende uma educação em que a diversidade não é somente constatada, mas também incluída e valorizada no currículo e nas práticas pedagógicas, de modo que o papel do professor se torna crucial, de mediação, para uma inter-relação entre as diferentes culturas existentes na escola. Objetivo: analisar a questão multicultural no espaço escolar a fim de compreender as abordagens e perspectivas para os povos indígenas. Metodologia: revisão bibliográfica do tipo sistemática integrativa. Resultados e Discussão: Considerando os critérios de inclusão estabelecidos durante a pesquisa foram selecionados 24 artigos que contemplaram duas categorias: a diversidade na sala de aula: implicações para as práticas pedagógicas; a educação para os povos indígenas sob a perspectiva multicultural. Conclusão: O multiculturalismo abre espaço para a vontade de cada indivíduo e de cada grupo em mostrar sua identidade aos outros; e todos, em conjunto, promovem e alcançam o interculturalismo, que pelo diálogo, pela troca de conhecimentos, práticas e comportamentos, integra essas vontades com o objetivo de promover a compreensão e a tolerância entre os indivíduos de origens diversas. A educação multicultural, mais especificamente, deve promover a partilha, a valorização e o respeito pela diversidade das culturas representadas na turma, na escola e na comunidade, assim como combater os preconceitos e as discriminações étnicas.

Descritores: Multiculturalismo. Pluralidade. Diversidade. Educação multicultural. Educação escolar indígena.

\footnotetext{
${ }^{1}$ marciamg@live.com

2 deadoutorado@hotmail.com

3 bj-sb@hotmail.com

4 isabell.maria2011@gmail.com

5 martaluciadir@gmail.com

6 lucianocanutojacinto11@gmail.com
} 


\begin{abstract}
Introduction: the perspective of multiculturalism emerges as an ideology that defends an education in which diversity is not only seen, but also included and valued in the curriculum and pedagogical practices, so that the role of the teacher becomes crucial, of mediation, for an interrelation between the different cultures existing in the school. Goal: to analyze the multicultural issue in the school space in order to understand the approaches and perspectives for indigenous peoples. Methodology: bibliographic review of the integrative systematic type. Results and Discussion: Considering the inclusion criteria established during the research, 24 articles were selected that contemplated two categories: diversity in the classroom: implications for pedagogical practices; education for indigenous peoples from a multicultural perspective. Conclusion: Multiculturalism makes room for the will of each individual and each group to show their identity to others; and all, together, promote and achieve interculturalism, which through dialogue, through the exchange of knowledge, practices and behaviors, integrates these wills with the aim of promoting understanding and tolerance among individuals of different origins. Multicultural education, more specifically, should promote sharing, appreciation and respect for the diversity of cultures represented in the class, at school and in the community, as well as combating prejudice and ethnic discrimination.
\end{abstract}

Descriptors: Multiculturalism. Plurality. Diversity. Multicultural education. Indigenous school education. 


\section{INTRODUÇÃO}

A diversidade cultural é um fato inquestionável de nossas sociedades, e posto que a cultura também inclui, entre outros aspectos, tradições religiosas e elementos de identidade, torna-se evidente a necessidade de pensar outras maneiras de convivência, ou de transformar as atuais maneiras, entre as diversas culturas que compartilham os mesmos marco espaçotemporais (CHICARINO, 2017). Já que nem todas as culturas estão em um plano de igualdade, é possível falar de identidades deslocadas ou também de culturas hegemônicas ou dominantes.

A cultura, em seu conceito teórico mais difundido, envolve o conjunto complexo de crenças, costumes, conhecimentos, hábitos e tradições compartilhadas pelos membros de uma sociedade, transmitidos de geração em geração (CANDAU, 2014). Hoje, devem estar implícitas as transformações constantes que os grupos minoritários trazem consigo e propagam no mundo. Assim, pensar a diversidade é interpelar a pluralidade, interrogando o lugar que essa pluralidade implica no contexto da educação. Dialogar com a diversidade é ter consciência de que o outro não pode ser reduzido à lógica do mesmo. É compreender a necessidade de preservar o outro em suas diferenças e em sua dignidade como pessoa (CHICARINO, 2017).

De acordo com Freitas de Lima (2014), uma proposta de convivência entre culturas provem do que se denomina multiculturalismo e interculturalismo, que em traços gerais diz respeito a individualidades e universalidades humanoculturais, promovidas no convívio comunitário em um intercâmbio constante. Tal convivência advoga pela inclusão de todos os cidadãos, seja na cultura, seja na vida democrática, além de ser propulsora de uma cultura de paz.

Bavaresco; Tacca (2016, p. 610) defende que "o multiculturalismo é a valorização da diversidade cultural que busca eliminar preconceitos e estereótipos construídos historicamente, procurando formar uma sociedade alicerçada no respeito e dignidade do outro com suas diferenças".

A perspectiva intercultural, por sua vez, surge como um prolongamento do multiculturalismo. Essa perspectiva vai além da convivência entre culturas, pois abrange aspectos como a identidade e o respeito na condição de caminho para o bem comum (FREITAS DE LIMA, 2014).

Vale a pena caracterizar $\mathrm{o}$ multiculturalismo e o interculturalismo, diferenciando-os e observando como ambos estão associados. $\mathrm{O}$ primeiro pressupõe a 
coexistência das culturas dos diversos grupos étnicos na sociedade. Os indivíduos mantêm suas identidades culturais, ou seja, a liberdade de participar em uma vida cultural e social própria, em circunstâncias iguais às das outras culturas. Essa coexistência desenvolve a igualdade de oportunidades das minorias e tem em conta os seguintes objetivos: aquisição de conhecimentos e competências necessárias à participação na cultura cívica nacional e à adesão aos ideais democráticos da igualdade, da justiça e da liberdade; afirmação dos aspectos mais importantes e identificadores da cultura materna do indivíduo; e participação ativa das famílias dos alunos na comunidade escolar (FREITAS DE LIMA, 2014).

O interculturalismo significa um duplo movimento de afirmação de cada cultura e abertura às outras culturas. Assim, as culturas tentam encontrar pontos comuns para se complementarem e enriquecerem umas às outras. Visa ainda a um conjunto de processos gerados pelas interações entre culturas em uma relação de trocas recíprocas.

No caso das escolas, desenvolve-se um clima de respeito e abertura a diversidade e transmissão de culturas. Os alunos e todos os outros agentes passam a ter uma vida rica em valores e conhecimentos culturais. $\mathrm{O}$ processo assenta-se na assimilação e na integração de novas atitudes, com destaque para a comunicação com o outro e a aceitação e valorização daquele que é diferente (FREITAS DE LIMA, 2014). Portanto, a educação será intercultural desde que potencialize a inter-relação entre as pessoas de distintas culturas e origens sociais.

A diversidade cultural, expressa na multiplicidade de fenômenos, desde fluxos migratórios e intercâmbios promovidos pela globalização até nacionalismos fundamentalistas, processos de exclusão social a partir da diferença e movimentos étnicos de vários tipos, desafiou a modernidade com base na correspondência entre um Estado e uma cultura nacional (CHICARINO, 2017). Atualmente, aceitase que a maioria dos Estados são plurinacionais, lugar de mais de uma cultura nacional e internacional, e pluriculturais, uma vez que apresentam e convivem com diferentes expressões de diversidade. Portanto, são necessários arranjos políticos, educacionais, sociais e humanos que facilitam a mútua compreensão e uma existência democrática e cidadã (CILIATO; SARTORI, 2015).

Desse modo, a perspectiva do multiculturalismo surge como uma ideologia que defende uma educação em que a diversidade não é somente constatada, mas também incluída e valorizada no 
currículo e nas práticas pedagógicas, de modo que o papel do professor se torna crucial, de mediação, para uma interrelação entre as diferentes culturas existentes na escola. "Portanto, é preciso pensar nas diferenças dentro de suas “diferenças", e o multiculturalismo abre espaço para refletir a complexidade e as divergências classificatórias da atualidade" (BAVARESCO; TACCA, 2016, p. 61).

Nesse sentido, concorda-se com Domingues; Cota (2014, p. 11) quando afirmam que referente ao processo de ensino aprendizagem "o destaque é atribuído à valorização da cultura do indivíduo, conferindo significado ao que lhe é proposto. [...] com o objetivo de desenvolver uma educação crítica para a superação da desigualdade e exclusão social e do modelo monocultural e hegemônico de educação". Dessa forma, entende-se que a educação precisa ajudar a gerar o ânimo e a confiança nas microculturas existentes, respeitando suas tradições, sua identidade cultural ou local, uma vez que é todo o conjunto de conhecimentos e modos de agir e pensar que enriquece o indivíduo como ser humano. Entretanto, o que se percebe comumente é que nem sempre a escola cumpre com essa premissa, de modo que a integração se faz, muitas vezes, ainda com base na aculturação. Diante dessa realidade faz-se necessário compreendê-la e transformá-la para a plena inclusão e êxito dos alunos, seja lá qual for sua etnia ou sua origem social (DOMINGUES; COTA, 2014).

Com isso, partindo da premissa de que a questão multicultural acontece a partir das interações sociais no ambiente escolar e que as experiências vivenciadas na sala de aula se desenvolvem entre os agentes que ali estão envolvidos e com isso cabe ao educador planejar e mediar o processo de ensino fazendo assim a diferença na aprendizagem dos alunos, o presente artigo insere-se nesse contexto objetivando analisar a questão multicultural no espaço escolar a fim de compreender as abordagens e perspectivas para os povos indígenas.

Para tanto foi realizada uma revisão bibliográfica do tipo sistemática integrativa sob o seguinte questionamento: de que forma a multiculturalidade é articulada no espaço escolar, com vistas às abordagens e perspectivas para os povos indígenas?

Assim, de maneira especial, buscase olhar o multiculturalismo, no espaço escolar, como universo plural, uma vez que essa pluralidade está representada por todos os agentes educacionais, ou seja, pelos discentes, docentes e demais pessoas envolvidas neste meio nos quais manifestam seus modos de ser e agir no mundo. Nesse ponto, atribui-se uma atenção especial ao agente professor, uma 
vez que a este fica o desafio de posicionarse diante dessa diversidade sem desmerecêla e para, além disso, interferir e reagir sempre que a intolerância manifestar-se em

\section{METODOLOGIA}

O presente estudo se desenvolveu por meio de uma revisão bibliográfica do tipo sistemática integrativa que adotou as seguintes etapas (detalhadas no quadro 01):

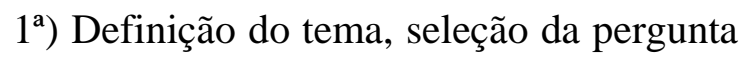
norteadora e escolha da estratégia de busca, descritores e bases de dados mais eficazes no levantamento das publicações; 2 $2^{\mathrm{a}}$ ) Escolha dos critérios de inclusão e exclusão; $3^{\text {a }) ~ I d e n t i f i c a c ̧ a ̃ o ~ d o s ~ e s t u d o s ~ p r e ́-~}$ selecionados e selecionados através da leitura dos agentes indexadores das publicações, como resumo, palavras-chave sua sala de aula, bem como construir práticas pedagógicas de promoção educacional, que interligue o respeito às diferenças.

e título, bem como organização dos estudos pré-selecionados e identificação dos estudos selecionados; $4^{\mathrm{a}}$ ): Categorização dos estudos selecionados, com elaboração e uso da matriz de síntese, além de análise das informações, formação de uma biblioteca individual e avaliação crítica dos estudos selecionados; $5^{\mathrm{a}}$ ) análise, interpretação e discussão dos resultados; $6^{\mathrm{a}}$ ) Apresentação da revisão em formato de artigo, o qual contemple propostas para estudos futuros (BOTELHO; CUNHA; MACEDO, 2011; SCHMOELLER et al., 2011).Quadro 1 Detalhamento das etapas da Revisão Sistemática Integrativa.

\begin{tabular}{|c|c|c|}
\hline ETAPA & TÓPICOS DE CADA ETAPA & DETALHAMENTO DE CADA TÓPICO \\
\hline \multirow[t]{6}{*}{$1^{a}$} & Tema & $\begin{array}{l}\text { A Questão Multicultural no espaço escolar: Desafios } \\
\text { para a Prática Pedagógica. }\end{array}$ \\
\hline & Pergunta norteadora & $\begin{array}{l}\text { De que forma a multiculturalidade é articulada no espaço } \\
\text { escolar, com vistas às abordagens e perspectivas para os } \\
\text { povos indígenas? }\end{array}$ \\
\hline & Objetivo geral & $\begin{array}{l}\text { Analisar a questão multicultural no espaço escolar a fim } \\
\text { de compreender as abordagens e perspectivas para os } \\
\text { povos indígenas. }\end{array}$ \\
\hline & Estratégias de busca & $\begin{array}{l}\text { Cruzamento de descritores por meio do operador boleano } \\
\text { AND; Uso de aspas nos politermos (descritor com mais } \\
\text { de um termo) para que a varredura de artigos científicos } \\
\text { contemplasse o termo exato; Uso de filtro do tipo data de } \\
\text { publicação. }\end{array}$ \\
\hline & Descritores livres e estruturados & $\begin{array}{l}\text { Multiculturalismo; Pluralidade; Diversidade; Educação } \\
\text { multicultural; Educação escolar indígena. }\end{array}$ \\
\hline & Bibliotecas Virtuais & $\begin{array}{l}\text { Scientific Electronic Library Online (SciELO); } \\
\text { Google Acadêmico; Revistas Eletrônicas. }\end{array}$ \\
\hline $2^{\mathrm{a}}$ & Período de coleta dos dados & Março a maio de 2020. \\
\hline
\end{tabular}




\begin{tabular}{|c|c|c|}
\hline & Critérios de inclusão & $\begin{array}{l}\text { Texto completo (disponível/free) do tipo: artigo original, } \\
\text { artigo de revisão, artigo na imprensa, recurso, editorial, } \\
\text { perspectiva e pesquisa transacional; Publicação (2014- } \\
\text { 2020). }\end{array}$ \\
\hline & Critérios de exclusão & $\begin{array}{l}\text { Livros, monografias, Trabalho de Conclusão de Curso, } \\
\text { Resumos, Relatórios, Teses e Dissertações; Artigos que } \\
\text { não contemplavam a relação entre a interculturalidade e } \\
\text { educação indígena. }\end{array}$ \\
\hline $3^{\mathrm{a}}$ & $\begin{array}{c}\text { Número de trabalhos } \\
\text { selecionados para revisão } \\
\text { sistemática integrativa a partir da } \\
\text { leitura dos agentes indexadores } \\
\text { das publicações (resumo, } \\
\text { palavras-chave e título) e } \\
\text { resultados, os quais deveriam } \\
\text { conter os descritores utilizados } \\
\text { nesse estudo }\end{array}$ & 24 trabalhos \\
\hline $4^{\mathrm{a}}$ & $\begin{array}{c}\text { Categorias obtidas com a análise } \\
\text { dos trabalhos científicos } \\
\text { investigados }\end{array}$ & $\begin{array}{l}\text { - A diversidade na sala de aula: implicações para as } \\
\text { práticas pedagógicas; } \\
\text { - A educação para os povos indígenas sob a perspectiva } \\
\text { multicultural. }\end{array}$ \\
\hline $5^{\mathrm{a}}$ & $\begin{array}{l}\text { Análise, interpretação e } \\
\text { discussão dos resultados }\end{array}$ & Ver em "Resultados e Discussão" \\
\hline $6^{\mathrm{a}}$ & $\begin{array}{l}\text { Apresentação da revisão em } \\
\text { formato de artigo, o qual } \\
\text { contemple propostas para estudos } \\
\text { futuros }\end{array}$ & Esse Artigo completo \\
\hline
\end{tabular}

Fonte: elaborada pela autora.

\section{RESULTADOS E DISCUSSÃO}

Considerando os critérios de inclusão estabelecidos durante a pesquisa foram selecionados 24 artigos que contemplavam a relação entre a questão multicultural no espaço escolar e os povos indígenas, conforme descritos resumidamente no Quadro 2.

Quadro 02 - Levantamento de Publicações Científicas de Acordo com os Critérios de Inclusão.

\begin{tabular}{|c|c|c|c|c|c|}
\hline$\underset{\mathrm{o}}{\mathrm{N}}$ & CITAÇÃO & TEMA & $\begin{array}{c}\mathbf{A N} \\
\mathbf{O}\end{array}$ & $\begin{array}{l}\text { OBJETIVO DO } \\
\text { ESTUDO }\end{array}$ & $\begin{array}{l}\text { CONCLUSÃO DO } \\
\text { ESTUDO }\end{array}$ \\
\hline 1 & $\begin{array}{l}\text { SANTOS, R. } \\
\text { B.; SERRÃ̂, } \\
\text { M. C. }\end{array}$ & $\begin{array}{l}\text { Educação escolar } \\
\text { indígena em } \\
\text { escolas urbanas: } \\
\text { realidade ou } \\
\text { utopia? }\end{array}$ & 2017 & 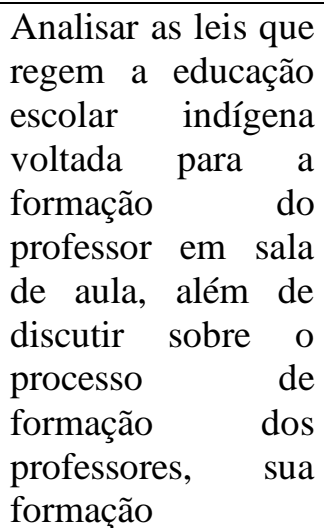 & $\begin{array}{l}\text { A partir das análises das } \\
\text { políticas educacionais } \\
\text { que regem a educação } \\
\text { escolar indígena e dos } \\
\text { dados coletados, } \\
\text { percebe-se } \\
\text { necessidade de se } \\
\text { considerar a realidade } \\
\text { educacional urbana na } \\
\text { qual os indígenas } \\
\text { encontram-se presentes } \\
\text { na formulação de }\end{array}$ \\
\hline
\end{tabular}




\begin{tabular}{|c|c|c|c|c|c|}
\hline & & & & $\begin{array}{lr}\text { continuada } & \mathrm{e} \\
\text { atuação } & \text { na } \\
\text { educação } & \text { escolar } \\
\text { indígena } & \text { no } \\
\text { município } & \text { de } \\
\text { Parintins, e } & \text { como } \\
\text { estes contribuem no } \\
\text { processo } & \text { de } \\
\text { aprendizagem } & \text { dos } \\
\text { alunos indígenas. }\end{array}$ & $\begin{array}{l}\text { políticas públicas além } \\
\text { de uma maior efetivação } \\
\text { das mesmas para que os } \\
\text { indígenas que estudam } \\
\text { em escola urbana } \\
\text { tenham formação } \\
\text { adequada } \\
\text { aprendizagem } \\
\text { qualidade, fortalecendo } \\
\text { assim sua cultura e não } \\
\text { deixando de lado suas } \\
\text { raízes. }\end{array}$ \\
\hline 2 & $\begin{array}{l}\text { RODRIGUES, } \\
\text { W. }\end{array}$ & $\begin{array}{c}\text { O ambiente } \\
\text { escolar e a } \\
\text { valorização } \\
\text { cultural indígena. }\end{array}$ & 2016 & $\begin{array}{l}\text { Relacionar estética } \\
\text { indígena e sua } \\
\text { possível utilização } \\
\text { nas aulas escolares } \\
\text { da região, } \\
\text { incentivando } \\
\text { futuros professores } \\
\text { a se utilizarem de } \\
\text { tal concepção. }\end{array}$ & $\begin{array}{l}\text { A inclusão dos indígenas } \\
\text { no ambiente escolar (nas } \\
\text { unidades escolares } \\
\text { dentro e fora das aldeias } \\
\text { e nas universidades) } \\
\text { deve ser pautada pelo } \\
\text { respeito ao outro, pelo } \\
\text { respeito à diferença e na } \\
\text { valorização das muitas } \\
\text { contribuições que esses } \\
\text { autóctones brasileiros } \\
\text { nos forneceram e nos } \\
\text { fornecem. Assim, o } \\
\text { estudo de personagens } \\
\text { indígenas presentes na } \\
\text { literatura pode favorecer } \\
\text { o surgimento de um } \\
\text { novo olhar sobre as } \\
\text { populações indígenas } \\
\text { nacionais, a fim de } \\
\text { fortalecer o } \\
\text { reconhecimento de suas } \\
\text { organizações sociais, } \\
\text { suas tradições, seus } \\
\text { saberes, seus fazeres, } \\
\text { seus valores simbólicos } \\
\text { e seus processos de } \\
\text { transmissão cultural. }\end{array}$ \\
\hline 3 & $\begin{array}{l}\text { DELMONDEZ, } \\
\text { P.; PULINO, L. } \\
\text { H. C. Z. }\end{array}$ & $\begin{array}{l}\text { Sobre identidade e } \\
\text { diferença no } \\
\text { contexto da } \\
\text { educação escolar } \\
\text { indígena }\end{array}$ & 2014 & $\begin{array}{lr}\text { Analisar a educação } \\
\text { escolar indígena, } \\
\text { mediante re as } \\
\text { concepções } & \text { de } \\
\text { identidade e de } \\
\text { diferença, para } \\
\text { traçar r uma } \\
\text { compreensão sobre } \\
\text { como as políticas } \\
\text { multiculturais de } \\
\text { educação vem } \\
\text { sendo concebidas e } \\
\text { praticadas } \\
\end{array}$ & \begin{tabular}{lrr}
\multicolumn{3}{l}{ Historicamente, a escola } \\
afirmou a & exclusão \\
social dos & povos \\
indígenas e & hoje, & visa \\
prepará-los & para \\
relações de & negociação \\
cultural, de & constituição \\
de novas & posições \\
identitárias & e & de \\
valorização & de & sua \\
diferença. & A \\
investigação & efetiva \\
contribuiu com o estudo
\end{tabular} \\
\hline
\end{tabular}




\begin{tabular}{|c|c|c|c|c|c|}
\hline & & & & $\begin{array}{l}\text { historicamente no } \\
\text { Brasil. }\end{array}$ & $\begin{array}{lr}\text { das } & \text { políticas } \\
\text { multiculturais } & \text { de } \\
\text { educação brasileiras } \\
\text { visando } \\
\text { desenvolvimento ao } \\
\text { psicologia social, numa } \\
\text { perspectiva critica. }\end{array}$ \\
\hline 4 & $\begin{array}{l}\text { SOUZA, R. S.; } \\
\text { SILVA, D. G. } \\
\text { GONÇALVES, } \\
\text { T. P. N. R. }\end{array}$ & $\begin{array}{l}\text { Multiculturalismo } \\
\text { e educação: o } \\
\text { espaço da gestão. }\end{array}$ & 2019 & $\begin{array}{l}\text { Analisar } r \text { como } \\
\text { questões } \\
\text { interesse de } \\
\text { multiculturalismo, } \\
\text { como diferenças de } \\
\text { raça, gênero e } \\
\text { sexualidade, } \\
\text { perpassam o } \\
\text { cotidiano da gestão } \\
\text { de uma escola } \\
\text { particular } \\
\text { localizada à zona } \\
\text { oeste da cidade do } \\
\text { Rio de Janeiro. }\end{array}$ & $\begin{array}{l}\text { De forma geral, os } \\
\text { resultados apontam para } \\
\text { uma dicotomia: embora } \\
\text { as escolas teoricamente } \\
\text { se esforce em tratar } \\
\text { positivamente de } \\
\text { problemas relacionados } \\
\text { com as diferenças } \\
\text { culturais junto aos } \\
\text { discentes, foi notado que } \\
\text { parte da equipe gestora e } \\
\text { parte das (os) } \\
\text { professoras (es) parece } \\
\text { produzir estereótipos } \\
\text { relacionados ao gênero e } \\
\text { à sexualidade. }\end{array}$ \\
\hline 5 & $\begin{array}{l}\text { PEREIRA, P. F. } \\
\text { S.; NETO, J. S. }\end{array}$ & $\begin{array}{l}\text { Um pouco além } \\
\text { dos territórios: o } \\
\text { direito } \\
\text { fundamental dos } \\
\text { povos indígenas a } \\
\text { uma educação } \\
\text { diferenciada }\end{array}$ & 2017 & $\begin{array}{l}\text { Analisar a } \\
\text { existência de um } \\
\text { direito à educação } \\
\text { diferenciada dos } \\
\text { povos indígenas, } \\
\text { sob a égide do } \\
\text { ordenamento } \\
\text { jurídico brasileiro. }\end{array}$ & $\begin{array}{l}\text { A preocupação com o } \\
\text { direito à educação } \\
\text { diferenciada dos povos } \\
\text { indígenas decorre do } \\
\text { fato de os mesmos } \\
\text { atualmente, sabedores } \\
\text { de seus direitos, tem } \\
\text { atuado nas esferas } \\
\text { discursivas formais e } \\
\text { informais apresentando } \\
\text { as suas reinvindicações, } \\
\text { o que perpassa pelo } \\
\text { respeito e garantia do } \\
\text { direito a terem um } \\
\text { processo educacional } \\
\text { que garante a diferença e } \\
\text { a pluralidade de seus } \\
\text { modos de vida. }\end{array}$ \\
\hline 6 & $\begin{array}{l}\text { SILVA, A. F. et } \\
\text { al. }\end{array}$ & $\begin{array}{l}\text { Educação } \\
\text { indígena. }\end{array}$ & 2016 & $\begin{array}{l}\text { Identificar } \\
\text { importância da } \\
\text { cultura indígena } \\
\text { para a educação e } \\
\text { refletir sobre ações } \\
\text { que contribuem } \\
\text { para o respeito à } \\
\text { diversidade cultural } \\
\text { e os direitos } \\
\text { humanos, } \\
\text { esclarecer ideias e } \\
\text { mitos }\end{array}$ & $\begin{array}{l}\text { Há uma gama de } \\
\text { oportunidades e desafios } \\
\text { para assegurar a inclusão } \\
\text { e o compromisso dos } \\
\text { estudantes indígenas } \\
\text { com os projetos sociais } \\
\text { de suas comunidades, } \\
\text { articulando tradição, } \\
\text { oralidade } \\
\text { conhecimento cientifico } \\
\text { em bases dialógicas, } \\
\text { reflexivas }\end{array}$ \\
\hline
\end{tabular}




\begin{tabular}{|c|c|c|c|c|c|}
\hline & & & & $\begin{array}{l}\text { preconceituosos ou } \\
\text { falsos a respeito do } \\
\text { povo indígena. }\end{array}$ & $\begin{array}{l}\text { propositivas. } \mathrm{O} \\
\text { conhecimento desse } \\
\text { povo agrega valor } \\
\text { histórico e político } \\
\text { frente às demandas da } \\
\text { educação, amplia } \\
\text { valores étnicos culturais, } \\
\text { criando novos caminhos } \\
\text { de inter-relações para o } \\
\text { conhecimento cientifico } \\
\text { e social. }\end{array}$ \\
\hline 7 & $\begin{array}{l}\text { FIGUEIREDO, } \\
\text { J. A. et al. }\end{array}$ & $\begin{array}{l}\text { A “inclusão" da } \\
\text { indígena na } \\
\text { escola. }\end{array}$ & 2017 & $\begin{array}{l}\text { Analisar } \\
\text { "inclusão" a } \\
\text { indígena na escola } \\
\text { "comum". }\end{array}$ & $\begin{array}{l}\text { O não conhecer da } \\
\text { cultura do outro pode } \\
\text { ocasionar visão } \\
\text { etnocêntrica, muitas } \\
\text { vezes impedindo de } \\
\text { visualizar outras } \\
\text { possibilidades, como a } \\
\text { convivência saudável } \\
\text { entre culturas distintas. } \\
\text { Na análise feita para a } \\
\text { construção desse } \\
\text { trabalho; talvez a maior } \\
\text { barreira tanto do } \\
\text { convívio, como de apoio } \\
\text { ao ensino seja a língua: } \\
\text { percebendo-se como } \\
\text { fator de dificuldade na } \\
\text { permanência de alunos } \\
\text { indígenas na escola } \\
\text { 'comum'. }\end{array}$ \\
\hline 8 & $\begin{array}{l}\text { GONÇALVES, } \\
\text { J. P.; } \\
\text { OLIVEIRA, E. } \\
\text { L. }\end{array}$ & $\begin{array}{l}\text { Uma diversidade } \\
\text { cultural e relações } \\
\text { de gênero em uma } \\
\text { escola indígena } \\
\text { sul-mato- } \\
\text { grossense. }\end{array}$ & 2018 & $\begin{array}{l}\text { Investigar a opinião } \\
\text { da comunidade } \\
\text { escolar de uma } \\
\text { aldeia indígena, } \\
\text { localizada no } \\
\text { município re } \\
\text { Tacuru (MS), } \\
\text { acerca do trabalho } \\
\text { desenvolvido por } \\
\text { professores } \\
\text { indígenas do gênero } \\
\text { masculino na } \\
\text { educação infantil. }\end{array}$ & $\begin{array}{l}\text { Os dados da pesquisa } \\
\text { evidenciam que na } \\
\text { cultura indígena as } \\
\text { crianças vivem junto da } \\
\text { comunidade onde todos } \\
\text { são educadores em } \\
\text { potencial, independente } \\
\text { do gênero, de modo que } \\
\text { o cargo de professor } \\
\text { dentro de uma aldeia } \\
\text { indígena pode ser } \\
\text { considerado um cargo de } \\
\text { prestigio. Além disso, } \\
\text { para as mulheres } \\
\text { indígenas é mais difícil } \\
\text { sair da aldeia em busca } \\
\text { de uma formação, o que } \\
\text { pode explicar a } \\
\text { significativa presença } \\
\text { masculina na educação }\end{array}$ \\
\hline
\end{tabular}




\begin{tabular}{|c|c|c|c|c|c|}
\hline & & & & & $\begin{array}{l}\text { infantil na aldeia } \\
\text { indígena pesquisada. }\end{array}$ \\
\hline 9 & SANTOS, M. D & $\begin{array}{c}\text { A educação } \\
\text { indígena na pós- } \\
\text { modernidade. }\end{array}$ & 2018 & $\begin{array}{l}\text { Discutir sobre } \\
\text { questões de } \\
\text { identidades na pós- } \\
\text { modernidade, os } \\
\text { enfrentamentos das } \\
\text { comunidades } \\
\text { tradicionais nesse } \\
\text { contexto, com a } \\
\text { perspectiva } \\
\text { intercultural que } \\
\text { rompe com as } \\
\text { visões } \\
\text { essencialistas, } \\
\text { genuínas e fixas das } \\
\text { culturas e sobre as } \\
\text { preposições das } \\
\text { visões } \\
\text { epistemológicas } \\
\text { decoloniais que } \\
\text { questionam a visão } \\
\text { geopolítica } \\
\text { conhecimento. do }\end{array}$ & $\begin{array}{l}\text { É na perspectiva } \\
\text { decolonial que há } \\
\text { possibilidade de pensar a } \\
\text { partir das ruinas, da } \\
\text { marginalização de } \\
\text { conhecimentos, do } \\
\text { racismo epistêmico e } \\
\text { intervir a fim de que haja } \\
\text { novas perspectivas, } \\
\text { novas pedagogias e } \\
\text { assim, contemplado os } \\
\text { etnoconhecimentos, } \\
\text { possam legitimá-los, } \\
\text { sistematiza-los e assim } \\
\text { (re)significar as } \\
\text { identidades que foram } \\
\text { subalternizadas. }\end{array}$ \\
\hline 10 & GRUBITS, S. & $\begin{array}{c}\text { Mulheres } \\
\text { indígenas } \\
\text { brasileiras: } \\
\text { educação e } \\
\text { políticas públicas }\end{array}$ & 2014 & $\begin{array}{lr}\text { Refletir até } & \text { que } \\
\text { ponto a } & \text { proposta } \\
\text { formulada } & \text { pela } \\
\text { Política } & \text { Nacional } \\
\text { para as } & \text { Mulheres } \\
\text { (PNM) (Secretaria } \\
\text { Especial } & \text { de } \\
\text { Políticas para as } \\
\text { Mulheres, } 2003 \text { ) } \\
\text { contempla } \\
\text { grupos de mulheres } \\
\text { indígenas. }\end{array}$ & $\begin{array}{l}\text { No caso dos } \\
\text { Guarani/Kaiawá, as } \\
\text { mulheres de Dourados } \\
\text { tem uma participação } \\
\text { mais ativa dentro e fora } \\
\text { da comunidade para } \\
\text { auxiliar na renda } \\
\text { familiar, e estimulam } \\
\text { mais seus filhos para } \\
\text { estudar e chegar até a } \\
\text { universidade. Entre os } \\
\text { Kadiwéu, o fato mais } \\
\text { relevante é a questão do } \\
\text { poder político das } \\
\text { mulheres e uma divisão } \\
\text { de papeis entre homens e } \\
\text { mulheres, sem que seja } \\
\text { atribuído mais valor a } \\
\text { um papel do que a outro. } \\
\text { No estudo com os } \\
\text { Terena, observamos que } \\
\text { a relação próxima com a } \\
\text { sociedade nacional vem } \\
\text { propiciando muitas } \\
\text { transformações e uma } \\
\text { atuação cada vez maior }\end{array}$ \\
\hline
\end{tabular}




\begin{tabular}{|c|c|c|c|c|c|}
\hline & & & & & $\begin{array}{l}\text { da mulher dentro e fora } \\
\text { da comunidade. }\end{array}$ \\
\hline 11 & $\begin{array}{l}\text { FREITAS DE } \\
\text { LIMA, E. }\end{array}$ & $\begin{array}{l}\text { A construção de } \\
\text { práticas } \\
\text { pedagógicas } \\
\text { inter/multiculturai } \\
\text { s no ensino } \\
\text { fundamental e os } \\
\text { saberes docentes. }\end{array}$ & 2014 & $\begin{array}{l}\text { Problematizar a } \\
\text { construção } \\
\text { práticas } \\
\text { pedagógicas } \\
\text { inter/multiculturais } \\
\text { no Ensino } \\
\text { Fundamental, em } \\
\text { contraponto com a } \\
\text { concepção de } \\
\text { saberes docentes. }\end{array}$ & $\begin{array}{l}\text { Para desenvolver os } \\
\text { conteúdos escolares } \\
\text { inter/multiculturalmente } \\
\text {, não basta que o docente } \\
\text { construa e acione } \\
\text { saberes, entendidos na } \\
\text { perspectiva racional; é } \\
\text { preciso que tais saberes } \\
\text { sejam conjugados com } \\
\text { crenças e valores } \\
\text { coerentes com esse tipo } \\
\text { de atuação, o que requer } \\
\text { uma autopercepção mais } \\
\text { honesta por parte dos } \\
\text { professores. }\end{array}$ \\
\hline 12 & $\begin{array}{c}\text { GALVÃO, C. } \\
\text { M. P.; } \\
\text { LACERDA, M. } \\
\text { C. }\end{array}$ & $\begin{array}{c}\text { Multiculturalismo } \\
\text { em educação }\end{array}$ & 2018 & $\begin{array}{l}\text { Abordar o que é } \\
\text { multiculturalismo, } \\
\text { onde surgiu, como } \\
\text { se processa e } \\
\text { desafios para a } \\
\text { superação dos } \\
\text { impasses gerados } \\
\text { por essa pluralidade } \\
\text { cultural. }\end{array}$ & $\begin{array}{l}\text { Defendemos } \\
\text { multiculturalismo } \\
\text { crítico para quem as } \\
\text { diferenças não tem um } \\
\text { fim em si, mas situam-se } \\
\text { num contexto de lutas } \\
\text { por mudança social, } \\
\text { contrapondo-se ao } \\
\text { ideário neoliberal e a } \\
\text { globalização econômica } \\
\text { e cultural vigente, como } \\
\text { expressões legítimas do } \\
\text { modelo capitalista } \\
\text { opressor. Contudo, } \\
\text { somos a favor do } \\
\text { multiculturalismo } \\
\text { crítico, entendendo que } \\
\text { o respeito à vida } \\
\text { humana, diversidade } \\
\text { cultural e essencial para } \\
\text { a construção de um } \\
\text { mundo de paz, como } \\
\text { futuro educador vemos } \\
\text { na instituição escolar } \\
\text { uma força maior que nos } \\
\text { conduzirá a esse } \\
\text { processo de justiça } \\
\text { social e democracia. }\end{array}$ \\
\hline 13 & $\begin{array}{l}\text { CILIATO, F. } \\
\text { G.; SARTORI, } \\
\text { J. }\end{array}$ & $\begin{array}{l}\text { Pluralidade } \\
\text { cultural: os } \\
\text { desafios aos } \\
\text { professores em } \\
\text { frente da } \\
\text { diversidade } \\
\text { cultural } \\
\end{array}$ & 2015 & $\begin{array}{l}\text { Abordar } r \\
\text { importância de } \\
\text { trabalhar na escola } \\
\text { com os temas } \\
\text { transversais, de } \\
\text { modo que contribua } \\
\text { para a formação de }\end{array}$ & $\begin{array}{l}\text { Levando } \\
\text { consideração a análise } \\
\text { do trabalho e do } \\
\text { contexto escolar, } \\
\text { notamos que os alunos } \\
\text { demonstram interesse } \\
\text { pelos assuntos e que }\end{array}$ \\
\hline
\end{tabular}




\begin{tabular}{|c|c|c|c|c|c|}
\hline & & & & $\begin{array}{l}\text { um cidadão ético e } \\
\text { responsável, } \\
\text { sobretudo, em } \\
\text { relação } \\
\text { pluralidade } \\
\text { cultural. }\end{array}$ & 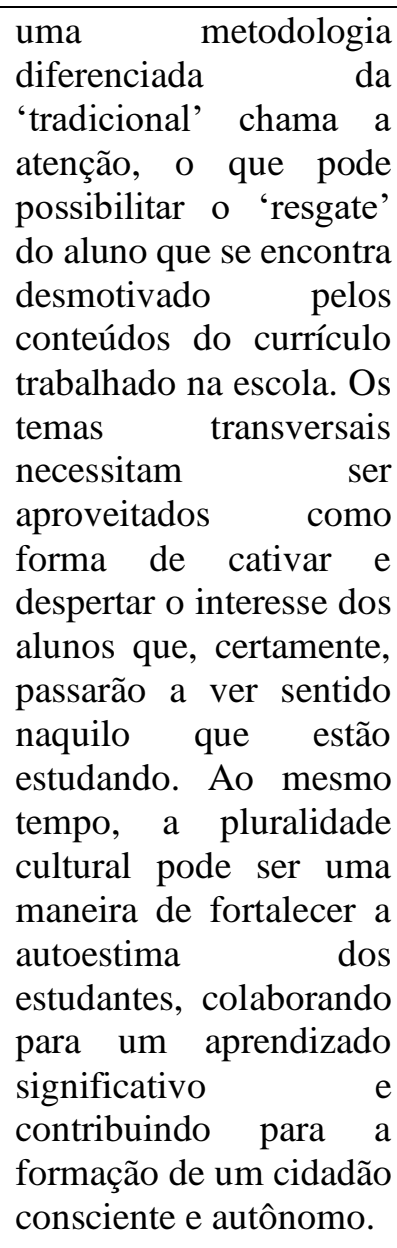 \\
\hline 14 & $\begin{array}{l}\text { KAYAPÓ, E.; } \\
\text { BRITO, T. }\end{array}$ & $\begin{array}{l}\text { A pluralidade } \\
\text { étnico-cultural } \\
\text { indígena no } \\
\text { Brasil: o que a } \\
\text { escola tem a ver } \\
\text { com isso? }\end{array}$ & 2014 & $\begin{array}{lr}\text { Analisar } & \text { as } \\
\text { possibilidades de } & \text { de } \\
\text { inovação no estudo } \\
\text { da história e cultura } \\
\text { indígena ras } \\
\text { escolas brasileira, } \\
\text { buscando romper } \\
\text { com ra } \\
\text { silenciamento e os } \\
\text { preconceitos } \\
\text { produzidos pelo } \\
\text { Estado, rada } \\
\text { sociedade e pela } \\
\text { escola ao longo do } \\
\text { tempo. }\end{array}$ & $\begin{array}{l}\text { Os esforços para a } \\
\text { promoção da Lei } \\
11.645 / 08 \text {, no que tange } \\
\text { ao estudo da história e } \\
\text { cultura indígena esbarra } \\
\text { em limites complexos, } \\
\text { entre eles, a morosidade } \\
\text { e o reduzido interesse } \\
\text { das escolas e poder para } \\
\text { promover cursos de } \\
\text { formação dos } \\
\text { professores e produção } \\
\text { de material didático } \\
\text { específico sobre a } \\
\text { temática. }\end{array}$ \\
\hline 15 & $\begin{array}{l}\text { MONTEIRO, F. } \\
\text { M. A.; } \\
\text { FONTOURA, } \\
\text { H. A.; CANEN, } \\
\text { A. }\end{array}$ & $\begin{array}{l}\text { Ressignificando } \\
\text { práticas de ensino } \\
\text { e de formação } \\
\text { docente: } \\
\text { contribuições de } \\
\text { narrativas, } \\
\text { diálogos e } \\
\text { conferências. }\end{array}$ & 2014 & $\begin{array}{l}\text { Apresentar } \\
\text { contribuições } \\
\text { compartilhadas } \\
\text { sobre dimensões } \\
\text { vinculadas às } \\
\text { práticas de } \\
\text { formação docente e } \\
\text { de pesquisa } \\
\text { desenvolvidas em } \\
\text { contextos diversos, }\end{array}$ & $\begin{array}{l}\text { Destacam-se } \\
\text { contribuições para os } \\
\text { desafios atuais da } \\
\text { educação. } \\
\text { especificamente, chama- } \\
\text { se a atenção para as } \\
\text { formas pelas quais tais } \\
\text { experiencias incorporam } \\
\text { sensibilidades às } \\
\text { diversidades culturais, }\end{array}$ \\
\hline
\end{tabular}




\begin{tabular}{|c|c|c|c|c|c|}
\hline & & & & $\begin{array}{l}\text { com interlocução } \\
\text { entre metodologias } \\
\text { e dados plurais. }\end{array}$ & $\begin{array}{l}\text { buscando caminhos } \\
\text { viabilizadores à } \\
\text { recontextualização das } \\
\text { estratégias e práticas } \\
\text { formativas docentes, em } \\
\text { prol de transformações } \\
\text { que incorporem } \\
\text { sensibilidades } \\
\text { multiculturais em seu } \\
\text { desenvolvimento. }\end{array}$ \\
\hline 16 & $\begin{array}{c}\text { ARAÚJO, N. } \\
\text { B.; MOTA, C. } \\
\text { M. A. }\end{array}$ & $\begin{array}{l}\text { Profissionalidades } \\
\text { e práticas docentes } \\
\text { multiculturais: } \\
\text { lugares possíveis? }\end{array}$ & 2017 & $\begin{array}{l}\text { Favorecer reflexões } \\
\text { acerca da inserção } \\
\text { da diversidade } \\
\text { cultural nas práticas } \\
\text { de sala de aula, } \\
\text { tomando-a sob um } \\
\text { enfoque } \\
\text { multicultural, } \\
\text { potencializador de } \\
\text { abordagens } \\
\text { educativas que se } \\
\text { centrem nas } \\
\text { discussões } \\
\text { demandas } \\
\text { realidade atual. }\end{array}$ & $\begin{array}{l}\text { Um fazer docente que } \\
\text { olha para a } \\
\text { multiculturalidade, } \\
\text { precisa estar muito bem } \\
\text { ancorado numa } \\
\text { abordagem para além do } \\
\text { reconhecimento da } \\
\text { diversidade, mas } \\
\text { tomando-a como } \\
\text { elemento que engendra } \\
\text { inúmeras questões } \\
\text { históricas, sociais e } \\
\text { culturais que precisam } \\
\text { ser revisitadas e, em } \\
\text { muitos casos, } \\
\text { descontruídas. Logo, as } \\
\text { abordagens não devem } \\
\text { prender-se a } \\
\text { superficialidades para } \\
\text { não corrermos o risco de } \\
\text { folclorizar, ao invés de } \\
\text { reconhecer para o } \\
\text { fortalecimento. }\end{array}$ \\
\hline 17 & $\begin{array}{c}\text { BAVARESCO, } \\
\text { P. R.; TACCA, } \\
\text { D. P. }\end{array}$ & $\begin{array}{l}\text { Multiculturalismo } \\
\text { e diversidade } \\
\text { cultural: uma } \\
\text { reflexão }\end{array}$ & 2016 & $\begin{array}{l}\text { Entender } \\
\text { conhecer como a } \\
\text { criança constrói sua } \\
\text { identidade e como } \\
\text { os educadores } \\
\text { valorizam esse } \\
\text { aspecto, } \\
\text { contribuindo para a } \\
\text { não existência de } \\
\text { preconceito no } \\
\text { espaço escolar. }\end{array}$ & $\begin{array}{l}\text { Uma escola considerada } \\
\text { multicultural, para ser de } \\
\text { qualidade deve, então, } \\
\text { ser inclusiva e deve } \\
\text { também apostar em um } \\
\text { sistema educativo } \\
\text { centrado no } \\
\text { relacionamento, na } \\
\text { igualdade, e que as } \\
\text { atividades estejam } \\
\text { voltadas para a } \\
\text { diversidade presente na } \\
\text { sala de aula. A ação do } \\
\text { professor deve ser um } \\
\text { ato intencional na sua } \\
\text { prática pedagógica; deve } \\
\text { reconhecer as diferenças } \\
\text { culturais e saber } \\
\text { valorizar o potencial da } \\
\text { diversidade de cada um. }\end{array}$ \\
\hline
\end{tabular}




\begin{tabular}{|c|c|c|c|c|c|}
\hline 18 & SILVA, J. B. & $\begin{array}{c}\text { Formação, } \\
\text { pesquisa e práticas } \\
\text { no contexto da } \\
\text { educação escolar } \\
\text { indígena: as ações } \\
\text { do PIBID } \\
\text { diversidade no } \\
\text { povo Xukuru do } \\
\text { Ororubá }\end{array}$ & 2017 & $\begin{array}{l}\text { Identificar o } \\
\text { trabalho realizado } \\
\text { nas escolas do povo } \\
\text { Xukuru. }\end{array}$ & 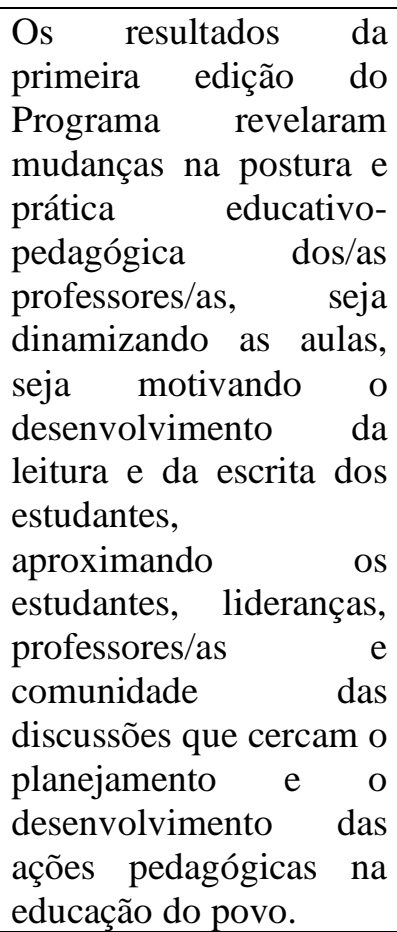 \\
\hline 19 & $\begin{array}{l}\text { ABU-EL-HAY, } \\
\text { M. F.; FIALHO, } \\
\text { L. M. F. }\end{array}$ & $\begin{array}{c}\text { Formação docente } \\
\text { e práticas } \\
\text { pedagógicas } \\
\text { multiculturais } \\
\text { críticas. }\end{array}$ & 2019 & $\begin{array}{l}\text { Compreender como } \\
\text { se constituiu a } \\
\text { formação docente } \\
\text { de professoras da } \\
\text { educação básica } \\
\text { estadunidense para } \\
\text { o desenvolvimento } \\
\text { de posturas e } \\
\text { práticas } \\
\text { multiculturais no } \\
\text { ambiente escolar. }\end{array}$ & $\begin{array}{l}\text { As histórias de vida das } \\
\text { professoras foram } \\
\text { marcadas por vivencias } \\
\text { em situações de conflito } \\
\text { social e experiências de } \\
\text { exclusão cultural e } \\
\text { educacional, } \\
\text { especialmente em } \\
\text { relação à diversidade } \\
\text { étnico-racial. Essas } \\
\text { vivencias foram } \\
\text { determinantes para a } \\
\text { busca da formação e } \\
\text { atuação profissional } \\
\text { docente dentro de uma } \\
\text { concepção de educação } \\
\text { multicultural. } \\
\text { formação } \\
\text { perspectiva se mostrou } \\
\text { relevante para a adoção } \\
\text { de práticas educativas } \\
\text { inclusivas, no entanto, } \\
\text { foram as experiencias de } \\
\text { exclusão que motivaram } \\
\text { o compromisso das } \\
\text { professoras com a } \\
\text { educação multicultural } \\
\text { crítica. }\end{array}$ \\
\hline 20 & $\begin{array}{c}\text { LISBOA } \\
\text { GROSS, D. G. } \\
\text { et al. }\end{array}$ & $\begin{array}{l}\text { Reflexões acerca } \\
\text { da etnicidade e } \\
\text { diversidade } \\
\text { cultural na BNCC } \\
\text { e no PNE }\end{array}$ & 2019 & $\begin{array}{l}\text { Apontar quais as } \\
\text { estratégias, metas } \\
\text { do PNE e as } \\
\text { competências da } \\
\text { BNCC acerca da }\end{array}$ & $\begin{array}{l}\text { Seria melhor que ambos } \\
\text { documentos atendessem } \\
\text { às políticas educacionais } \\
\text { e que se levasse em } \\
\text { consideração sempre a }\end{array}$ \\
\hline
\end{tabular}




\begin{tabular}{|c|c|c|c|c|c|}
\hline & & & & $\begin{array}{l}\text { etnicidade } \\
\text { diversidade } \\
\text { cultural. }\end{array}$ & $\begin{array}{l}\text { multiplicidade } \\
\text { realidades das escolas, } \\
\text { infraestruturas, culturas, } \\
\text { formações profissionais } \\
\text { e o aluno, respeitando a } \\
\text { peculiaridade e a } \\
\text { singularidade de cada } \\
\text { cenário, envolvendo } \\
\text { assim a correta } \\
\text { compreensão r da } \\
\text { etnicidade e diversidade } \\
\text { cultural. }\end{array}$ \\
\hline 21 & $\begin{array}{l}\text { DOMINGUES, } \\
\text { M. P. B.; } \\
\text { COTA, F. S. }\end{array}$ & $\begin{array}{l}\text { A diferença na } \\
\text { sala de aula: } \\
\text { reflexões sobre a } \\
\text { história indígena } \\
\text { escolar e a história } \\
\text { de educação } \\
\text { inclusiva }\end{array}$ & 2014 & $\begin{array}{l}\text { Trazer reflexões } \\
\text { sobre o ensino da } \\
\text { história indígena } \\
\text { escolar e sobre a } \\
\text { história ra da } \\
\text { educação inclusiva, } \\
\text { no sentido de } \\
\text { promover um } \\
\text { diálogo crítico entre } \\
\text { a multiplicidade de } \\
\text { sujeitos, tempos, } \\
\text { lugares e culturas. }\end{array}$ & $\begin{array}{l}\text { Repensar e ressignificar } \\
\text { a concepção de educador } \\
\text { deve ser uma prática, e } \\
\text { através desta propor } \\
\text { estímulos que ativem as } \\
\text { diferenças entre os } \\
\text { sujeitos em seu contexto } \\
\text { histórico, cultural e } \\
\text { social e na elaboração de } \\
\text { sentidos. Formandos } \\
\text { sujeitos da melhor } \\
\text { forma, para viver a vida } \\
\text { em sua plenitude, } \\
\text { atendendo as suas } \\
\text { especificidades } \\
\text { respondendo e } \\
\text { necessidades de cada } \\
\text { um. }\end{array}$ \\
\hline 22 & $\begin{array}{c}\text { COUTINHO, } \\
\text { C.; } \\
\text { RUPPENTHAL } \\
\text {. R. }\end{array}$ & $\begin{array}{c}\text { Cultura e } \\
\text { educação } \\
\text { científica: } \\
\text { alternativas } \\
\text { pedagógicas para } \\
\text { inserção do } \\
\text { multiculturalismo } \\
\text { na formação } \\
\text { inicial de } \\
\text { professores. }\end{array}$ & 2016 & $\begin{array}{lr}\text { Trazer à } & \text { tona } \\
\text { reflexões referentes } \\
\text { à multicultura } \\
\text { educação, na } \\
\text { especial em } \\
\text { educação científica. }\end{array}$ & $\begin{array}{l}\text { Pode-se destacar a } \\
\text { presença dos aspectos } \\
\text { referentes a } \\
\text { multiculturalidade desde } \\
\text { a elaboração dos PCN } \\
\text { em 1997, bem como em } \\
\text { outros documentos. } \\
\text { Entretanto, ainda faltam } \\
\text { trabalhos ou pesquisas } \\
\text { que contribuam no } \\
\text { sentido de oferecer } \\
\text { subsídios para que } \\
\text { práticas multiculturais } \\
\text { se façam presente nas } \\
\text { escolas, direcionadas } \\
\text { aos estudantes ou aos } \\
\text { professores, em } \\
\text { formação ou que já estão } \\
\text { na atividade. }\end{array}$ \\
\hline 23 & $\begin{array}{l}\text { NAZZARENO, } \\
\text { E.; ARAÚJO, } \\
\text { O. C. G. }\end{array}$ & $\begin{array}{l}\text { Reflexões em } \\
\text { torno do tema } \\
\text { contextual } \\
\text { "etnicidade e }\end{array}$ & 2017 & $\begin{array}{l}\text { Apresentar } \quad \text { o } \\
\text { desenvolvimento } \\
\text { do tema contextual } \\
\text { "etnicidade } \\
\text { diversidade }\end{array}$ & $\begin{array}{lr}\mathrm{Na} \text { condição } & \text { de } \\
\text { professores, } & \text { os } \\
\text { estudantes afirmaram } \\
\text { estar cientes do que é } \\
\text { fundamental } & \text { que }\end{array}$ \\
\hline
\end{tabular}




\begin{tabular}{|c|c|c|c|c|c|}
\hline & & $\begin{array}{l}\text { diversidade } \\
\text { cultural" }\end{array}$ & & \begin{tabular}{lr}
\multicolumn{3}{l}{ cultural" ministrado } \\
no curso de \\
Licenciatura em \\
Educação \\
Intercultural da \\
Universidade \\
Federal de Goiás.
\end{tabular} & $\begin{array}{l}\text { estejam preparados para } \\
\text { atuar na escola a fim de } \\
\text { assegurar a revitalização } \\
\text { da lingua materna e da } \\
\text { cultura de cada povo por } \\
\text { meio da escola bilingue } \\
\text { intercultural. Mais do } \\
\text { que isto, houve a } \\
\text { compreensão de que é } \\
\text { necessário continuar a } \\
\text { luta pela permanência do } \\
\text { reconhecimento e do } \\
\text { respeito pela diversidade } \\
\text { cultural brasileira bem } \\
\text { como da garantia dos } \\
\text { direitos constitucionais } \\
\text { indígenas obtidos na } \\
\text { constituição de } 1988 \text {. }\end{array}$ \\
\hline 24 & $\begin{array}{c}\text { FERRÃO } \\
\text { CANDAU, V. } \\
\text { M. }\end{array}$ & $\begin{array}{l}\text { Ser professor/a } \\
\text { hoje: novos } \\
\text { confrontos entre } \\
\text { saberes, culturas e } \\
\text { práticas. }\end{array}$ & 2014 & 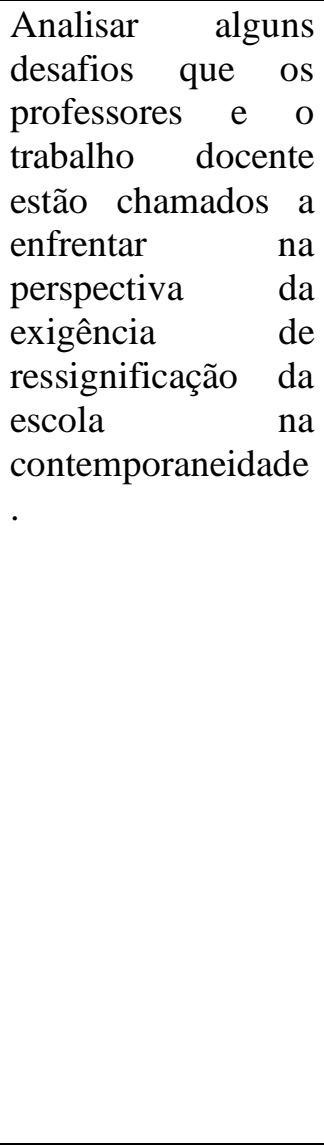 & 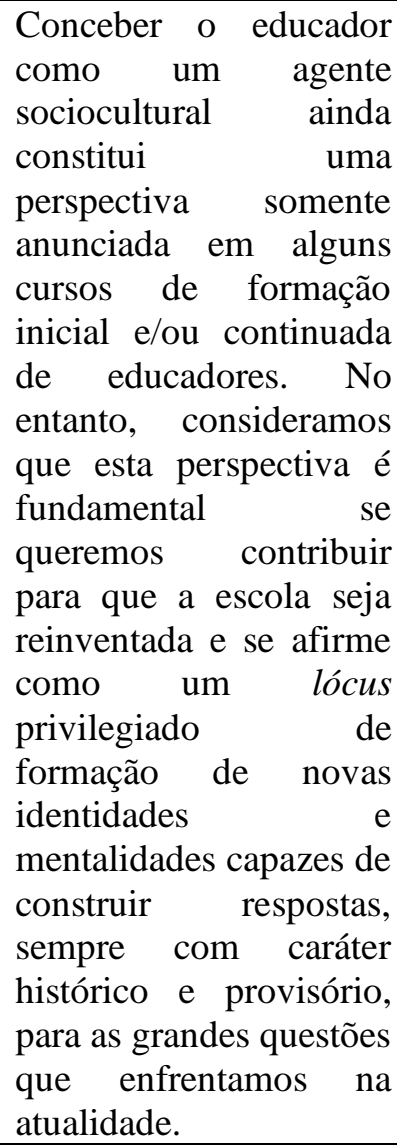 \\
\hline
\end{tabular}

Fonte: elaborado pela autora.

\section{A Diversidade na Sala de Aula:} Implicações para as Práticas Pedagógicas

O Brasil possui uma constituição que the confere a condição de nação pluriétnica. Entretanto, durante décadas tal diversidade cultural brasileira não foi reconhecida equanimemente pela escola. Como reflexo do processo histórico, observou-se no ambiente escolar "o predomínio, para não dizer hegemonia, da 
matriz cultural europeia como cultura eleita para o trabalho pedagógico. Porém, a atual discussão sobre as conjunturas sociais tem promovido aberturas de espaços para maior número de contestações e revoltas dos diversos setores excluídos" (Gonçalves, 2012, apud Michaliszyn, 2014, p. 105).

É possível perceber que há certo abismo entre a cultura escolar e a cultura de referência dos alunos, principalmente se estes pertencerem a grupos sociais, étnicas e culturas marginalizados. No entanto, não se pode discordar que a educação é fundamental na construção e na valorização de um mundo verdadeiramente plural. Assim, quando a escola adota modelos tradicionais, supervalorizando a cultura determinada pela minoria que detém o controle social, assume uma posição manipuladora e massificadora (CANDAU, 2014).

Para Moser (2017), esse cenário exige dos profissionais da educação constantes reflexões acerca das relações entre cultura e educação. Os critérios de avaliação devem ser concebidos considerando a perspectiva da diversidade e do multiculturalismo. Além disso, o professor deve respeitar as noções de dignidade humana e a justiça, pois não há homogeneidade cultural, cada sujeito atribui diferentes sentidos e significados sociais.
De acordo com Domingues; Cota (2014, p. 12), “aos professores é designado um grande desafio: superar uma tradição que pretende instituir e dar legitimidade a identidades sociais únicas e hegemônicas, apagando diferenças". Desse modo é importante que o professor considere cada aluno como um sujeito portador de características socioculturais próprias e, portanto, resultantes de suas vivências, sempre considerando que em sua inserção como ator social no universo da cultura, cada sujeito constrói-se a partir do momento em que é estimulado a apropriar-se, a criar e a recriar os elementos culturais a que têm acesso, num diálogo constante com os componentes da estrutura social e com as contradições nela presentes (CANDAU, 2014).

A educação e a cultura da diversidade trabalham para tornar a sociedade cooperativa e solidária, calcada no respeito pela diferença e pelos direitos humanos, tornando os homens $\mathrm{e}$ as mulheres justos e livres. Aqui, a escola tem um papel fundamental: é ela o agente de transformação social. A escola, e todos os espaços em que a educação acontece, compreende as diferenças dos alunos com um grande valor e não como elemento de segregação por isso a tolerância é essencial (CANDAU, 2014). 
O processo educativo compreende o oferecimento de instrumentos e alternativas para que os indivíduos tomem consciência de si, do outro e, de modo geral, da sociedade na qual vivem. Para tanto, sugere-se, como estratégia para eliminar posturas etnocêntricas, a adoção do relativismo cultural como norteador ético. Isso “implica em tornar acessível aos alunos o conhecimento sobre as diferentes sociedades e atores sociais, descontruir discursos discriminatórios e dar aos estudantes uma compreensão de que somos constituídos como sujeitos na diversidade de experiências históricas com o 'outro", (DOMINGUES; COTA, 2014, p. 12).

No que diz respeito ao ambiente na sala de aula, é preciso que o professor tenha em mente um processo educativo que valoriza e se preocupa com a diversidade que deve ser marcado pelo ato de ponderar sobre as relações sociais estabelecidas na escola e pela constante reflexão sobre as diferenças, a desigualdade social e suas consequências. Nesse sentido, Bavaresco; Tacca (2016, p. 66) ressaltam que, "os educadores precisam considerar os princípios de uma educação inclusiva valorizando a diversidade humana, a celebração das diferenças, o direito de sentir-se parte, de pertencer, a igualdade de todos e o desenvolvimento de todas as crianças no ensino regular, na busca de uma escola para todos".

É nesse contexto que se destaca a educação multicultural onde “o entendimento do multiculturalismo como princípio educativo, deve favorecer aprendizagens que olhem para os valores sociais e culturais do outro, não de forma hierárquica, mas dialógica e relacional, partindo da realidade constituinte do espaço escolar" (ARAÚJO; MOTA, 2017, p. 70).

Assim, pensar o processo de ensino e aprendizagem numa perspectiva multicultural não significa promover festas, trabalhar com manifestações folclóricas, lendas e mitos.

Para além disso - ou melhor, em paralelo a todas essas ações, que tampouco devem ser descartadas -, devemos ter sempre em mente que lidamos com realidade distintas e culturas diversificadas (ARAÚJO; MOTA, 2017).

Para além das mudanças curriculares, é necessário o desenvolvimento de ações que ampliem as possibilidades de implementação de atividades e projetos que possam sugerir o envolvimento dos alunos com os diferentes grupos culturais, onde a relação teoria/prática no que se refere à diversidade cultural é favorecida (ARAÚJO; MOTA, 2017) 
Araújo; Mota (2017, p. 81) sinalizam que "um fazer docente que olha para a multiculturalidade, precisa estar muito bem ancorado numa abordagem para além do reconhecimento da diversidade, mas tomando-a como elemento que engendra inúmeras questões históricas, sociais e culturais que precisam ser revisitadas e, em muitos casos, desconstruídas".

Assim, considerando que as diversas formas de expressões e grupos culturais invadem a sala de aula, compreende-se que por esse motivo a escola não pode ser pensada apenas por um determinado grupo social. A diversidade deve fazer parte da escola, através da gestão democrática, garantindo a participação de todos na construção dos espaços de ensino e aprendizagem. Fica evidente que respeitar a diversidade não se refere somente a incluir diferentes grupos no mesmo espaço, mas se refere à participação de todos nesse espaço (MOSER, 2017).

Bavaresco; Tacca (2016, p. 65), afirmam que "a diversidade humana presente na escola traz constantes discussões acerca de como os professores devem, em sua prática pedagógica diária, abranger a quantidade inesgotável de diferenças que compõem o meio escolar". Por isso, é importante que os professores administrem a heterogeneidade presente em seu grupo de alunos, ampliando os processos de gestão da turma, fortalecendo uma relação de apoio em especial àqueles alunos que mais precisam de atenção para superar suas dificuldades, bem como fomentando uma relação de apoio e incentivo entre os alunos. Dessa forma "a ação do professor deve ser um ato intencional na sua prática pedagógica; deve reconhecer as diferenças culturais e saber valorizar o potencial da diversidade de cada um" (BAVARESCO; TACCA, 2016, p. 67).

Essa nova realidade educacional solicita que o processo educativo seja repensado e que se busquem novos caminhos para construção de conhecimentos que poderão inovar a prática pedagógica. Coutinho; Ruppenthal (2016, p. 46) ressaltam que "para as práticas multiculturais chegarem até a escola, é importante que os professores tenham algum preparo na implementação de atividades que considerem as diferentes culturas". Nesse sentido, destaca-se "a necessidade de uma formação docente que traga presente os fundamentos sobre o multiculturalismo em que seja oportunizado um trabalho articulado entre teoria e prática que ofereça mecanismos para o desenvolvimento de práticas pedagógicas pautadas nas questões da cultura local [...]" (ARAÚJO; MOTA, 2017, p. 73). 
É possível encontrar na literatura diversos estudos sobre a formação e a prática docente que abordam o conhecimento, o saber docente e sua formação enfocando a necessidade de buscar e repensar alternativas que possam contribuir para mudanças na prática profissional do professor, partindo de outra forma de entender, de praticar e de organizar o trabalho. Para Araújo; Mota (2017, p. 71), “a Formação docente é mecanismo de grande relevância para a construção de novas concepções educacionais que possam estar embasadas nos princípios de ressignificação a partir da superação de proletarização da profissão e busca pela autonomia que a mesma requer".

Os estudos apontados na literatura têm apresentado uma nova epistemologia da prática profissional e apontam para a melhoria da qualidade na formação docente, de forma a atender aos desafios da sociedade contemporânea. As práticas educativas, na perspectiva multicultural, tornaram-se o foco das discussões entre legisladores e educadores, com o intuito de melhorar a orientação dos professores no que se refere ao processo de ensinoaprendizagem que valorize a diversidade na sala de aula. Araújo; Mota (2017, p. 75), esclarecem que "o processo de trabalho com e para a diversidade precisa estar muito bem alicerçado pelo binômio teoria e prática, uma vez que não dá para pensar em um fazer educativo, sem estar centrado nas questões de seu tempo, sem o estabelecimento de uma postura analíticoreflexiva por parte daqueles que constituem elemento central de todo esse processo: o docente".

Abu-El-Haj; Fialho (2019, p. 23) afirmam que, "essa constatação reconhece o valor da formação acadêmica multicultural na prática pedagógica do professor" tendo em vista que, no momento em que o profissional observa as questões do seu cotidiano e as coloca como situações problemáticas, isso o levará à reflexão, então, uma reflexão na própria ação. Isso permitirá a ele reorientar sua ação a respeito da situação que vivencia. Entende-se com isso, que o professor precisa ser capaz de agir de forma a garantir um movimento de ação-reflexão-ação, e isso ocorrerá quando esse profissional fizer uma leitura de sua prática, seus conceitos e suas posturas, tornando-se assim um profissional reflexivo.

Quando o professor não assume essa postura, ele não avalia sua atuação, não reflete sobre seu cotidiano e, dessa forma, não tem condições de recriar as teorias, deixando de adequar sua prática de acordo com a realidade.

Segundo Araújo; Mota (2017, p. 81) "romper com práticas escolares 
cristalizadas não é uma tarefa simples e fácil, principalmente porque estas estão muito bem alicerçadas em antigos entornos formativos e sociais de uma parcela bastante significativa dos docentes que ora desenvolvem tais práticas". Assim, a postura do professor enquanto pesquisador é fundamental para a realização de uma autoavaliação e reformulação de sua prática. "Destarte, a dimensão formativa docente, enquanto lugar da profissionalidade que tem a prática norteada pela criticidade e autonomia, mostra-se como elemento fundamental para $o$ favorecimento de reflexões que venham repercutir em práticas que, de fato, potencializem as diferenças".

Diante disso, entende-se que a formação multicultural deverá apresentar para os docentes um conjunto de estratégias baseadas em programas curriculares que expressem a diversidade de culturas e estilos de vida, tendo em vista a promoção da mudança de percepções e atitudes que facilitem a compreensão e a tolerância entre indivíduos de origens étnicas diversas. Tais estratégias deverão promover a igualdade e a eliminação da discriminação, de preconceitos existentes na sociedade. Isso é fundamental para dar voz aos alunos, fazendo que eles tenham um papel ativo na escola e na sociedade à qual pertencem.

\section{A Educação para os Povos Indígenas sob a Perspectiva Multicultural}

A Educação Indígena é caracterizada pela metodologia habitual de aquisição de conhecimentos e costumes intrínsecos de cada etnia. Sobrinho, Souza e Bettiol (2017, p. 59) afirmam que "estes saberes/conhecimentos são ensinados/aprendidos de forma oral no dia a dia, nos rituais, nos mitos e nas distintas formas de organização de cada comunidade". Como se sabe o contato entre os colonizadores e os povos colonizados iniciou um processo de aculturação que marcou a história da sociedade brasileira, onde os povos indígenas e africanos foram brutalmente escravizados visando $\mathrm{o}$ progresso e a riqueza dos colonizadores.

Para Lima et al (2017, p. 45) “A história brasileira mostra que a relação entre o Estado e os povos indígenas foi pautada pela dominação, por meio da integração e homogeneização cultural, ao invés do pluralismo cultural". Assim, esses procedimentos, que envolviam a escravização dos povos indígenas, bem como as iniciativas de catequizá-los e domesticá-los, aumentou consideravelmente as desigualdades sociais vivenciadas por esse grupo étnico até os momentos atuais.

No que se refere à história da educação escolar indígena, o que se sabe é 
que desde o início da colonização até a promulgação da Constituição Federal (CF) de 1988, os programas educacionais fundamentaram-se na desvalorização e abandono das referências culturais e práticas sociais indígenas, objetivando assim incorporar os valores e significados europeus (AFONSO, 2016).

Nesse sentido Silva e Freitas (2014, p. 10) afirmam que "todas as iniciativas educativas implementadas por meio das políticas indigenistas anteriores à Constituição Federal de 1988, tinham como o propósito de realizar um trabalho pedagógico na perspectiva de abolir com as especificidades étnicas e culturais e por meio da negação a sociodiversidade do Brasil".

Embora os colonizadores tenham tentado integrar os povos indígenas à sociedade brasileira através de uma educação assimilacionista, excluindo as culturas e valores indígenas, o que se percebeu é que tal modelo educacional "não conseguiu efetivamente desconstruir suas identidades e seus sentimentos de pertencimento a um povo que não queria perder suas origens e referências identitárias"

Desse modo, os povos indígenas brasileiros lutaram para manter viva as culturas, "mostrando que em suas comunidades é presente a coexistência de costumes ancestrais com traços culturais recentes" (PESSOA, 2017, p. 210).

A partir da promulgação da Constituição de 1988 quando "novas políticas culturais são definidas e novos grupos sociais ganham visibilidade no campo histórico-cultural e patrimonial" (VOLKMER et al., 2015, p. 53), vários povos indígenas perceberam que a educação escolar seria um meio de reduzir a desigualdade existente, e com isso estabeleceriam seus direitos e suas conquistas, além de promover um “diálogo intercultural entre diferentes agentes sociais" (SOBRINHO, SOUZA E BETTIOL, 2017, p. 59).

Desse modo, Nessa luta pelo reconhecimento da sociedade, os indígenas brasileiros no século XX, tendo a orientação e o apoio de vários representantes dos movimentos sociais, além de lutar pelo direito às suas terras, empreenderam também uma luta pelo direito à uma Educação Escolar Indígena, onde suas culturas e seus saberes fossem fortalecidos e valorizados (PESSOA, 2017).

Com isso, observa-se que nas últimas décadas, através dos movimentos de afirmação étnica, um novo modelo escolar surgiu no cenário educacional brasileiro: a escola dos e para os povos indígenas, protegida por leis que determinaram um paradigma individualizado e específico de 
educação escolar, onde as ações destinadas à educação escolar indígena fez dela atualmente o agrupamento dos direitos políticos e culturais dos povos indígenas brasileiros, sendo portanto, uma modalidade de ensino inclusivo que foi reivindicada por lideranças, comunidades e professores indígenas que fizeram parte das lutas dos povos indígenas pela garantia e proteção territorial e pelo reconhecimento da diversidade sociocultural, específicas da constituição da cidadania indígena no Brasil (PESSOA, 2017).

Nesse sentido, ao consideramos a educação e $\mathrm{o}$ processo de ensino e aprendizagem no cenário indígena e de sua relação com os espaços sociais, torna-se imprescindível o debate de uma educação impregnada pela diversidade como disciplina, em que a autoimagem do povo indígena seja afirmada e revitalizada (SANTOS, 2018).

Em resposta à experiência histórica do período escravista, a educação mostrouse um caminho fértil para a reprodução dos valores sociais e/ou civilizatórios das várias etnias indígenas e de seus descendentes (RODRIGUES, 2016). No entanto, as mazelas e a aniquilação física, moral humana e cultural forjadas ao longo de nossa história não impediram as populações indígenas de promover a continuidade de sua cultura no sentido mais amplo, bem como o ensinamento de suas visões de mundo.

Em sua figura individual e em suas coletividades a identidade dos povos indígenas foi preservada como patrimônio da educação. Apesar das precárias condições de sobrevivência ainda enfrentadas, a relação com a ancestralidade e a mitologia indígena, e com os valores nelas representados, permitiu a dinamicidade da cultura e do processo de resistência das diversas comunidades indígenas (RODRIGUES, 2016).

O estado brasileiro tem uma responsabilidade histórica pelo escravismo e pela marginalização econômica, social e política dos descendentes dos índios, que persiste em tempos contemporâneos. O racismo e as práticas discriminatórias disseminadas no cotidiano brasileiro, por exemplo, não podem representar e ser justificados simplesmente como uma herança do passado (CHICARINO, 2017).

Outra responsabilidade do Estado, atuando nesse âmbito, é debater e elaborar estratégias de enfrentamento da dinâmica das relações raciais no Brasil. A admissão dessas responsabilidades históricas constitui o primeiro passo para a construção e a implementação do plano de ação do Estado brasileiro, com intuito de instrumentalizar e colocar em prática 
resoluções, em especial as voltadas para a educação, quais sejam:

- Igual acesso à educação para todos e todas na lei e na prática.

- Adoção e implementação de leis que pró́bam a discriminação baseada em raça, cor, descendência, origem nacional ou étnica em todos os níveis de educação, tanto formal quanto informal.

- Medidas necessárias para eliminar os obstáculos que limitam o acesso de crianças à educação.

- Recursos para eliminar, onde existam, desigualdades nos rendimentos educacionais para jovens e crianças.

- Apoio aos esforços que assegurem ambiente escolar seguro, livre da violência e de assedio motivados por racismo, discriminação racial, xenofobia e intolerância correlata.

- Estabelecimento de programas de assistência financeira desenhados para capacitar todos os estudantes, independentemente de raça, cor, descendência, origem étnica ou nacional a frequentarem instituições educacionais de ensino superior (CAVALLEIRO, 2006, apud CHICARINO, 2017).

As campanhas realizadas pelo movimento indigenista possibilitam ao Estado brasileiro formular projetos no sentido de promover políticas e programas para a população indígena e valorizar a história e a cultura desse povo por meio da estruturação de uma política nacional de educação calcada em práticas antidiscriminatórias (CHICARINO, 2017).

As populações indígenas que passaram pelos primeiros contatos com os portugueses, vivenciaram um processo de reconfiguração de sua história de vida para adaptação ao novo mundo, cujas marcas serviram de base para a criação de estratégias de sobrevivência (AFONSO, 2016).

A fuga dos trabalhadores escravizados, a conquista de territórios para a formação de tribos materializa as formas mais reconhecidas de luta da população indígena escravizada. Nesses espaços, as populações indígenas abrigaram-se, tentaram manter sua religião emblemática, onde a cosmovisão fundamentava-se no animismo $^{1}$ e elaboraram novas maneiras de organização social, bastante distintas da organização de origem (AFONSO, 2016).

Diante disso, cabe, portanto, ligar essas experiências e essa diversidade ao cotidiano escolar, convertendo-as em conhecimento para todos os atores envolvidos com o processo de educação, em especial professores e alunos. O silêncio da escola sobre como se dá as dinâmicas das relações étnicas no dia a dia brasileiro tem permitido a transmissão aos alunos de uma pretensa hegemonia (AFONSO, 2016). 
Essa atitude permite que cada um construa, a seu modo, um entendimento muitas vezes estereotipado do outro que lhe é diferente.

A expressão 'negociação cultural' remete às relações de poder, ao domínio e orientação intelectual e, inclusive, comportamental, que uma classe exerce sobre outra. Justamente por isso a educação, partindo das diferenças humanas e culturais, de como elas se inter-relacionam, mediante o conflito ou o equilíbrio, assume o papel de estimular o aluno a ver o mundo a ver o outro, primeiro como seu par, com quem convive em sociedade, e que esse outro, ainda que lhe seja igual, porque humano, com mesmos direitos e deveres, carrega dentro de si uma identidade, uma gama de conhecimentos, de pensamentos, que pode transformar o mundo e que, portanto, deve ser respeitada (LAMEGO E SANTOS, 2019).

A discussão em torno do termo 'multiculturalismo' entendido, em geral como a luta de "grupos sociais subalternizados e marginalizados pela elite hegemônica, buscando reconhecimento e valorização dos sujeitos socioculturais que compõem grupos minoritários" (LAMEGO E SANTOS, 2019, p. 11), tem forte relação com o movimento negro no mundo. Entretanto, outros grupos como mulheres e índios, assim como os negros tentaram reivindicar "perante as autoridades políticas seus direitos e deveres como cidadãos" (GALVÃO; LACERDA, 2018, p. 143). Nesse contexto, o movimento indígena, o movimento trabalhista, o movimento feminista e o movimento LGBT tiveram de lutar, em muitos casos com a própria vida de seus militantes, tendo seus próprios corpos violados, para que essa força essencial que tem dentro de si seja, ao menos, respeitada. Não por coincidência, o multiculturalismo nasce com e nessas lutas de minorias sociais (CHICARINO, 2017). As minorias ainda tem muitas lutas a travar, porque toda a exploração teórico-conceitual aqui desenvolvida não encontra plena concretude na realidade, de modo que existem ainda desafios, a saber:

- Necessidade de desconstrução dos paradigmas preconceituosos, monoculturais e etnocêntricos das práticas escolares, o que exige o combate à naturalização dessas práticas, que vão desde as políticas públicas aos conteúdos escolares.

- Articulação entre igualdade e diferença nas políticas e práticas educativas, buscando o reconhecimento das diferenças de conhecimentos, saberes e práticas dos grupos sociais, mediados pelo paradigma da educação para todos, emergente especialmente a partir dos anos 1990.

- Resgate das identidades culturais individuais e coletivas. 
- Promoção de experiências de interação entre culturas, com o objetivo de relativizarmos a nossa cultura e nos colocarmos perante os outros de forma respeitosa, reconhecendo-os como portadores de sentidos, de uma cultura, mas não apenas como pequenos momentos de interação, e sim um projeto em que esta ocorra em caráter sistemático.

- Empoderamento dos atores sociais historicamente menos privilegiados, ou mesmo discriminados, abrindo possibilidades para que sejam sujeitos da sua vida.

\section{CONCLUSÃO}

Deparamo-nos com a multiculturalidade em nosso dia a dia e, especialmente, nos espaços coletivos, por exemplo, nas escolas, onde existem cada vez mais pessoas e grupos de culturas diversas. Pensamos que esse fato é um enriquecimento comum, porque aprendemos a cooperar, a conviver e a compreender a vida também no horizonte do outro, quando esses lugares se tornam espaços de e para todos, cumprindo ainda um papel de inclusão de minorias.

A escola inserida em um contexto mais amplo, ou seja, no interior de uma comunidade, de uma sociedade, configura um local por excelência para a produção de
- Formação para uma cidadania aberta e interativa, capaz de reconhecer as assimetrias de poder entre os diferentes grupos culturais e de trabalhar os conflitos e promover relações solidárias (CANDAU, 2008, apud CHICARINO, 2017).

Essas bandeiras de lutas, por assim dizer, devem ser assumidas por todo educador, por toda família e por todo estudante, uma vez que elas constituem um projeto de ação, de humanidade, mais do que um projeto simplesmente educativo.

relações de aprendizagem, nomeadamente, da aprendizagem cultural.

Pensemos a perspectiva intercultural como uma extensão ao multiculturalismo, como algo que surge a partir deste. Essa perspectiva vai além da convivência entre culturas, pois abrange aspectos como a identidade, o respeito enquanto caminho para o bem comum. Viver em conjunto, apesar das tensões conflituosas que podem emergir, provoca o entrecruzamento de múltiplas tradições, chegando ao ponto de se tornar espaço comum.

É preciso estar atento a esses cruzamentos para, então, estimular os lugares de reencontro, pois as tradições, assim como a convivência, não são unicamente conflituosas. 
$\mathrm{Na}$ sociedade observamos determinados comportamentos, tais como: códigos e suas respectivas apropriações; expectativas e emoções subjacentes a esses comportamentos habituais; artefatos produzidos e utilizados; instituições políticas, sociais e culturais em funcionamento ou sendo repensadas e atualizadas para novas necessidades; e finalmente formas várias de relações humanas. Isso é cultura, é a vida social acontecendo.

O multiculturalismo abre espaço para a vontade de cada indivíduo e de cada grupo em mostrar sua identidade aos outros; e todos, em conjunto, promovem e alcançam o interculturalismo, que pelo diálogo, pela troca de conhecimentos,

\section{REFERÊNCIAS}

ABUL-EL-HAJ, M. F.; FIALHO, L. M. F. Formação docente e práticas pedagógicas multiculturais críticas. Revista Educação em Questão. Natal, v. 57, n. 53, p. 1-27, e17109, jul./set., 2019.

AFONSO, Germano Bruno. Ensino deHistória e Cultura Indígenas. Curitiba: Intersaberes, 2016.

ARAÚJO, N. B.; MOTA, C. M. A. Profissionalidades e práticas docentes multiculturais: lugares possíveis? Org. e Demo, Marília, v. 18, n. 2, p. 69-82, jul./dez., 2017.

BAVARESCO, P. R.; TACCA, D. P. Multiculturalismo e diversidade cultural: práticas e comportamentos, integra essas vontades com o objetivo de promover a compreensão e a tolerância entre os indivíduos de origens diversas.

Para que isso se concretize é preciso que a educação cumpra seu papel e, em seu conjunto de estratégias organizacionais, curriculares e pedagógicas, promova a igualdade racial e elimine as formas de discriminação e opressão, quer individuais quer institucionais. A educação multicultural, mais especificamente, deve promover a partilha, a valorização e o respeito pela diversidade das culturas representadas na turma, na escola e na comunidade, assim como combater os preconceitos e as discriminações étnicas.

uma reflexão. Unoesc e Ciência - ACHS, Joaçaba, v. 7, n. 1, p. 61-68, jan./jun., 2016.

CANDAU, V, M. F. Ser professor/a hoje: novos confrontos entre saberes, culturas e práticas. Educação. v. 37, n. 1, enero-abril, p. 33-41. Pontifícia Universidade Católica do Rio Grande do Sul, porto Alegre, 2014.

CILIATO, F. L. G.; SARTORI, J. Pluralidade cultural: os desafios aos professores em frente da diversidade cultural. Revista Monografias Ambientais - REMOA, v. 14, p. 65-78, 2015.

CHICARINO, T. Diversidade cultural. Pearson Education do Brasil, São Paulo, 2017. 
COUTINHO, C.; RUPPENTHAL, R. Cultura e educação científica: alternativas pedagógicas para inserção do multiculturalismo na formação inicial de professores. Revista Signos, Ensino, Humanidades. Lajeado, ano 37, n. 1, 2016.

DELMONDEZ, P.; PULINO, L. H. C. Z. Sobre identidade e diferença no contexto da educação escolar indígena. Psicologia e sociedade, 26 (3), p. 632-642, 2014.

DOMINGUES, M. P. B.; COTA, F. S. A diferença na sala de aula: reflexões sobre a história indígena escolar e a história de educação inclusiva. Revista do LhistaLaboratório de Ensino de História e Educação. n. 1, v. 1, julho/dezembro, 2014.

FIGUEIREDO, J. A. et al A "inclusão" do indígena na escola. Revista Panorâmica, on-line. Barra das Garças - MT, v. 23, p. 76-86, jul./dez., 2017.

FREITAS DE LIMA, E. A construção de práticas pedagógicas inter/multiculturais no ensino fundamental e os saberes docentes. Revista Diálogo Educacional, v. 14, n. 42, mai./ago., p. 395-414, 2014.

GALVÃO, C. M. P.; LACERDA, M. C. Multiculturalismo em educação. Revista Saberes, UNIJIPA - JI - Paraná, v. 8, n. 1, jan./jun., 2018.

GONÇALVES, J. P.; OLIVEIRA, E. L. Uma diversidade cultural e relações de gênero em uma escola indígena sul-matogrossense. Revista Educação e Pesquisa, São Paulo, v. 44, e1851444, 2018.

GRUBITS, S. Mulheres indígenas brasileiras: educação e políticas públicas. Psicologia e Sociedade. 26(1), 116-125, 2014.

KAIAPÓ, E.; BRITO, T. A pluralidade étnico-cultural indígena no Brasil: o que a escola tem a ver com isso? Caicó, v. 15, n. 35, p. 38-68, jul./dez. 2014. Dossiê Histórias Indígenas.

LAMEGO, C. R. S.; SANTOS, M. C. F. Formação de professores e educação intercultural: concepções e práticas de licenciados sobre diversidade cultural na educação básica. Contexto \& Educação. Editora Unijuí, Ano 34, no 108, Mai./Ago. 2019.

LIMA, N. F. et al. Educação e interculturalidade: a formação dos professores indígenas. Revista Humanidades e Inovação. v. 4, n. 4, 2017.

LISBOA GROSS, D. G. et al. Reflexões acerca da etnicidade e diversidade cultural na BNCC e no PNE. Revista

Humanidades e Inovação. v. 6, n. 18, 2019.

MICHALISZYN, M. S. Educação e Diversidade. Revista Intersaberes, Curitiba, v. 12. 2014.

MONTEIRO, F. M. A; FONTOURA, H. A.; CANEN, A. Ressignificando práticas de ensino e de formação docente: contribuições de narrativas, diálogos e conferências. Revista Educação Pública. v. 23, n. 53/2, p. 637-654, mai./ago., 2014. MOSER, A. C. Educação e Diversidade. Santa Catarina, Editora: Uniasselvi, 2017.

NAZARENO, E.; ARAÚJO, O. C. G. Reflexões em torno do tema contextual "etnicidade e diversidade cultural".

Articul. Constr. Saber, Goiânia, v. 2, n. 1, p. 116-132, 2-17.

PEREIRA, P. F. S.; NETO, J. S. Um pouco além dos territórios: o direito fundamental dos povos indígenas a uma educação diferenciada. Revista da Faculdade de Direito - RFD -UERJ, Rio de Janeiro, n. 31, jun, 2017. 
PESSOA, H. C. C. Narrativas de professores indígenas sobre o cotidiano escolar. Revista Ensino Interdisciplinar. v. 3, n. 08, VERN, Mossoró, RN, maio/2017.

RODRIGUES, W. O ambiente escolar e a valorização cultural indígena. Periferia: Educação, Cultura e comunicação. V. 8, n. 1, jan.-jun., 2016.

SANTOS, M. D. A educação escolar indígena na pós-modernidade. Revista Panorâmica, v. 25, 2018. (Edição Comemorativa).

SANTOS, R. B.; SERRÃO, M. C.

Educação escolar indígena em escolas urbanas: realidade ou utopia? Revista Eletrônica Mutações - RELEM, jul-dez, 2017.

SILVA, A. F. et al. Educação Indígena. Revista Maiêutica. Indaial, v. 4, n. 1, p. 65-74, 2016.

SILVA, A. R.; FREITAS, M. C. S. A institucionalização da educação escolar indígena no Brasil. Revista Científica
Vozes do Vales - UFV. JM, MG - Brasil, n. 06, ano III-10/2014.

SILVA, J. B. Formação, pesquisa e práticas no contexto da educação escolar indígena: as ações do PIBID diversidade no povo Xucuru do Ororubá. Ñanduty. v. 5, n. 7, 2017.

SOBRINHO, R. S. M.; SOUZA, A. S. D.; BETTIOL, C. A. A educação escolar indígena no brasil: uma análise crítica a partir da conjuntura dos 20 anos de LDB. Unisul, Tubarão, v.11, n. 19, p. 58 - 75, Jan/Jun 2017.

SOUZA, R. S.; SILVA, D. G.; GONÇALVES, T. P. N. R.

Multiculturalismo e educação: o espaço da gestão. Revista Caminhos da Educação: diálogos, culturas e diversidades. CAEDU/UFPI, Teresina, Brasil, v. 1, p. 154-174, janeiro/abril, 2019.

VOLKMER, M. S. et al. Educação e diversidade cultural: culturas indígenas e africanas na sala de aula. Revista de História e Geografia. Santa Cruz do Sul, v. 17, n. 02, p. 52-63, jul./dez. 2015. 


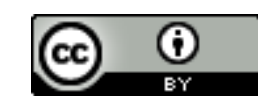

Esta obra está sob o direito de Licença Creative Commons Atribuição 4.0 Internacional.

\title{
O LÚDICO NA EDUCAÇÃO INDÍGENA
}

\author{
Marta Lúcia Silva Costa ${ }^{1}$ \\ Andrea Marques Vanderlei Fregadolli ${ }^{2}$ \\ Betijane Soares de Barros ${ }^{3}$ \\ Marcia Lucia Costa da Silva
}

\section{RESUMO}

Introdução: A criança está em fase de constante aprendizagem sobre o mundo em que está inserida, é um ser que depende do cuidado dos adultos para sobreviver e precisa se adaptar ao que solicita a sociedade. Trazendo essa realidade para a educação infantil indígena entende-se que essa criança possui uma capacidade de entendimento diferenciada e é de grande importância para o professor respeite o tempo que ela precisa para aprender, pois assim, reconhecendo a realidade dos seus alunos o professor fará um planejamento a partir dos problemas encontrados, realizando uma avaliação no processo de ensino-aprendizagem. Objetivo: analisar a concepção da ludicidade a fim de compreender os caminhos construídos para essa prática na educação infantil indígena. Metodologia: revisão sistemática integrativa. Resultados e Discussão: Considerando os critérios de inclusão estabelecidos durante a pesquisa foram selecionados 30 artigos que contemplavam a relação entre a ludicidade e educação infantil indígena. Assim, com a análise dos trabalhos científicos investigados obteve-se as seguintes categorias: a utilização da ludicidade como recurso pedagógico na sala de aula; a educação da criança indígena; a ludicidade na educação infantil indígena. Conclusão: é importante utilizar a ludicidade como recurso pedagógico na educação infantil indígena, uma vez que ela supre a necessidade da curiosidade e descoberta que a criança possui. Considerando que esta utilização, quando trabalhada de forma adequada, pode ser fundamentada tanto na formação educativa, quanto na formação cultural da criança indígena, entende-se que esta prática se torna, indiscutivelmente necessária no processo ensino-aprendizagem.

Descritores: Ludicidade. Educação infantil indígena. Brincadeiras e jogos indígenas.

\begin{abstract}

\footnotetext{
1 martaluciadir@gmail.com

2 deadoutorado@hotmail.com

3 bj-sb@hotmail.com

4 marciamg@live.com
}

Introduction: The child is in a phase of constant learning about the world in which he is inserted, he is a being who depends on the care of adults to survive and needs to adapt to what society requires. Bringing this reality to indigenous early childhood education, it is understood that this child has a differentiated understanding capacity and is of great importance for the teacher to respect the time he needs to learn, because thus, recognizing the reality of his students, the 
teacher will make a planning based on the problems encountered, carrying out an evaluation in the teaching-learning process. Objective: to analyze the concept of playfulness in order to understand the paths built for this practice in indigenous early childhood education. Methodology: systematic integrative review. Results and Discussion: Considering the inclusion criteria established during the research, 30 articles were selected that contemplated the relationship between playfulness and indigenous child education. Thus, with the analysis of the investigated scientific works, the following categories were obtained: the use of playfulness as a pedagogical resource in the classroom; the education of indigenous children; playfulness in indigenous children's education. Conclusion: it is important to use playfulness as a pedagogical resource in indigenous early childhood education, since it meets the need for the child's curiosity and discovery. Considering that this use, when properly worked, can be based on both educational and cultural training of indigenous children, it is understood that this practice becomes, arguably necessary in the teaching-learning process.

Descriptors: Playfulness. Indigenous child education. Indigenous games and games. 


\section{INTRODUÇÃO}

A criança está em fase de constante aprendizagem sobre o mundo em que está inserida, é um ser que depende do cuidado dos adultos para sobreviver e precisa se adaptar ao que solicita a sociedade. Nessa fase, necessita aprender tudo o que seja importante para sua sobrevivência.

Trazendo essa realidade para a educação infantil indígena entende-se que essa criança possui uma capacidade de entendimento diferenciada e é de grande importância para o professor respeite o tempo que ela precisa para aprender, pois assim, reconhecendo a realidade dos seus alunos o professor fará um planejamento a partir dos problemas encontrados, realizando uma avaliação no processo de ensino-aprendizagem. Assim, compreendese que na Educação Infantil indígena respeitar o tempo dessa criança é essencial para alcançar o sucesso desejado.

A sistematização dos conteúdos feita pelos professores em sala de aula não reflete o conhecimento de mundo (em constante transformação) trazido pelos educandos, continuando assim como metodologias focadas no resultado, na nota, que leva à aprovação ou à reprovação. A questão que mais envolve a problemática do processo de ensino-aprendizagem hoje na visão dos professores passa por como ensinar essa geração que se encontra tão envolta em necessidades afetivas, sociais, motoras e linguísticas e ao mesmo tempo tão vazia em habilidades que promovam reflexão e a construção do conhecimento.

É sabido que chamar a atenção das crianças na sala de aula não é uma tarefa impossível, embora em alguns momentos pode apresentar-se como algo desafiador. Nesse sentido, a ludicidade surge como ferramenta imprescindível nesse momento, visto que é possível utilizá-la de diferentes formas, tornando-a um recurso pedagógico em consonância com a orientação metodológica do trabalho.

Vivenciar a ludicidade em sala de aula é permitir favorecer ao mesmo tempo, o desenvolvimento da corporeidade, da capacidade de compartilhar significados, sentimentos, e de imaginar, na medida em que acabam por se constituir em jogos dramáticos, danças e imitações que exploram a gestualidade e a linguagem cênica.

O presente artigo insere-se nesse contexto, que através da revisão sistemática integrativa, objetiva analisar a concepção da ludicidade a fim de compreender os caminhos construídos para essa prática na educação infantil indígena.

A fim de elaborar tal reflexão teórica foi realizado um estudo fundamentando-se em leituras críticas dos artigos revisados dos seguintes autores: Melo (2019), Luckesi (2014), Domingues-Lopes (2015), Porto 
(2018), Antunes e Batista (2017), e Santana et al (2016) abordaram a temática da utilização da ludicidade como recurso pedagógico na sala de aula; Silva (2014), Andriolli e Faustino (2019), Troquez (2016), Grando (2014), Grando (2016), Ives-Felix e Nakayama (2018), Bergamaschi e Menezes (2016), Jankauskas et al (2015), Pinho e Tomazzetti (2017), Melo e Ribeiro (2019) e Almeida et al (2017) trataram sobre a educação da criança indígena e Silva et al (2015), Rodrigues (2018), Ramires e Mota (2018), Conti et al

\section{METODOLOGIA}

O presente estudo se desenvolveu por meio de uma revisão bibliográfica do tipo sistemática integrativa que adotou as seguintes etapas (detalhadas no quadro 02): $1^{\text {a) }}$ Definição do tema, seleção da pergunta norteadora e escolha da estratégia de busca, descritores e bases de dados mais eficazes no levantamento das publicações; $2^{\mathrm{a}}$ ) Escolha dos critérios de inclusão e exclusão; $3^{\text {a }}$ ) Identificação dos estudos préselecionados e selecionados através da leitura dos agentes indexadores das publicações, como resumo, palavras-chave
(2017), Delle Piagge et al (2019), Mota e Ramires (2018), Tenório e Silva (2014), Faustino e Mota (2016), Martins et al (2019), Barros et al (2014), Conti et al (2018) e Figueiredo e Azevedo (2014) versaram acerca da ludicidade na educação infantil indígena.

Em suma toda a temática dos artigos estudados traz à reflexão o uso da ludicidade na educação infantil indígena, considerando que esta pode ser um instrumento pedagógico muito significativo e de grande valor social.

e título, bem como organização dos estudos pré-selecionados e identificação dos estudos selecionados; $4^{\mathrm{a}}$ ): Categorização dos estudos selecionados, com elaboração e uso da matriz de síntese, além de análise das informações, formação de uma biblioteca individual e avaliação crítica dos estudos selecionados; $5^{\text {a }}$ ) análise, interpretação e discussão dos resultados; $6^{\mathrm{a}}$ ) Apresentação da revisão em formato de artigo, o qual contemple propostas para estudos futuros (BOTELHO; CUNHA; MACEDO, 2011; SCHMOELLER et al., 2011).

Quadro 1 - Detalhamento das etapas da Revisão Sistemática Integrativa.

\begin{tabular}{|c|c|l|}
\hline ETAPA & TÓPICOS DE CADA ETAPA & \multicolumn{1}{c|}{ DETALHAMENTO DE CADA TÓPICO } \\
\hline \multirow{2}{*}{$1^{\mathrm{a}}$} & \multicolumn{1}{|c|}{ Tema } & O Lúdico na Educação Indígena \\
\cline { 2 - 3 } & Pergunta norteadora & $\begin{array}{l}\text { De que forma a ludicidade é articulada no espaço escolar } \\
\text { infantil indígena? }\end{array}$ \\
\hline
\end{tabular}




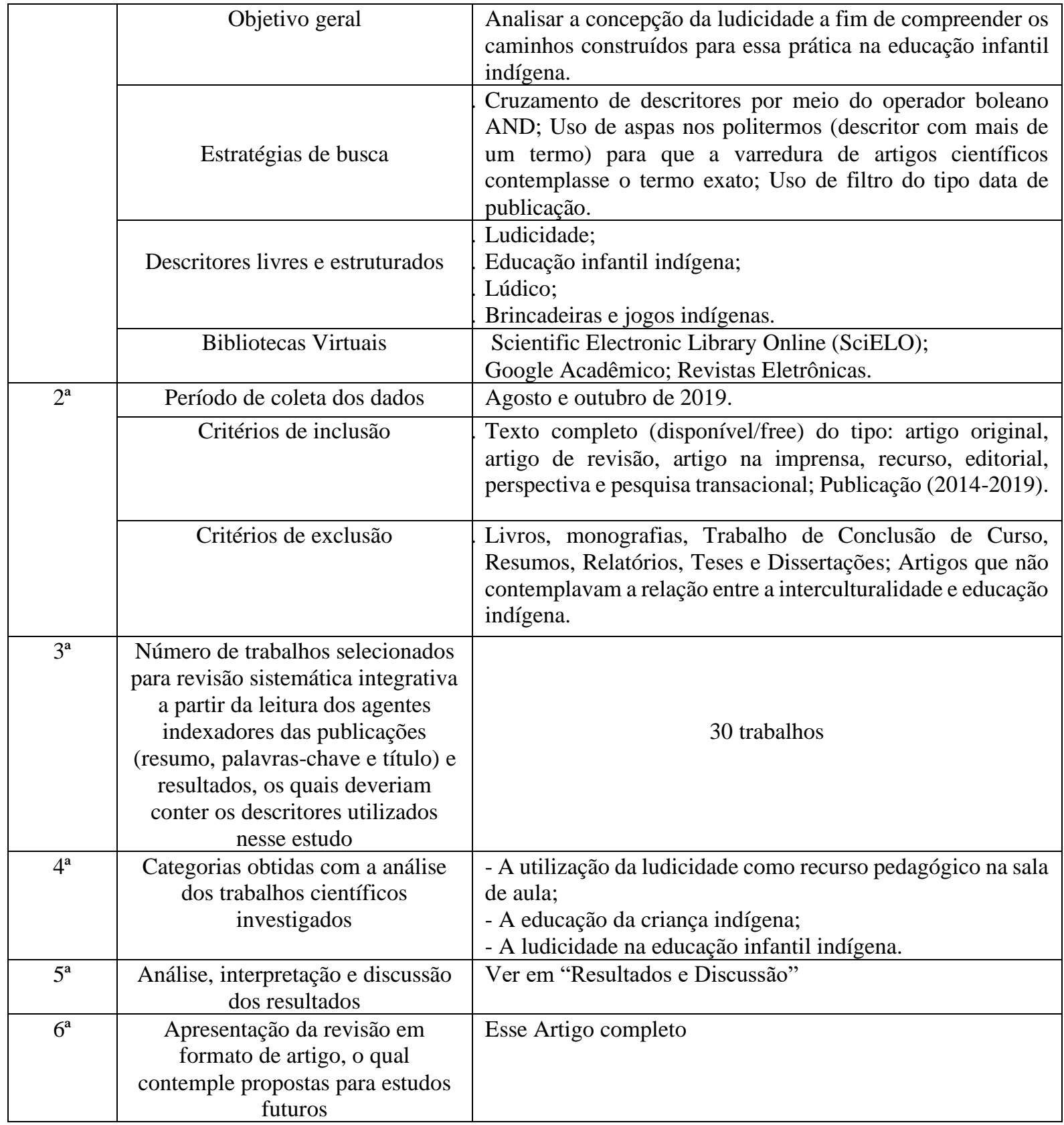

Fonte: elaborada pela autora.

\section{Resultados e Discussão}

\section{Considerando os critérios de} inclusão estabelecidos durante a pesquisa foram selecionados 30 artigos que contemplavam a relação entre a interculturalidade e educação indígena, conforme descritos resumidamente no quadro 02.

Quadro 02 - Levantamento de Publicações Científicas de Acordo com os Critérios de Inclusão.

\begin{tabular}{|c|c|c|c|c|c|}
\hline $\mathrm{N}^{\mathrm{o}}$ & CITAÇÃ̃O & TEMA & ANO & $\begin{array}{c}\text { OBJETIVO DO } \\
\text { ESTUDO }\end{array}$ & $\begin{array}{c}\text { CONCLUSÃO DO } \\
\text { ESTUDO }\end{array}$ \\
\hline
\end{tabular}




\begin{tabular}{|c|c|c|c|c|c|}
\hline 1 & $\begin{array}{l}\text { ANTUNES, } P . ; \\
\text { BATISTA, F. M. R. }\end{array}$ & $\begin{array}{c}\text { Brincar de } \\
\text { aprender: a } \\
\text { ludicidade como } \\
\text { recurso didático na } \\
\text { educação infantil }\end{array}$ & 2017 & $\begin{array}{l}\text { Trabalhar a inserção } \\
\text { da criança no mundo } \\
\text { pedagógico por meio } \\
\text { das atividades lúdicas } \\
\text { e sua interação no } \\
\text { processo ensino- } \\
\text { aprendizagem da } \\
\text { educação infantil. }\end{array}$ & $\begin{array}{l}\text { Os professores e alunos } \\
\text { devem trabalhar visando } \\
\text { o desenvolvimento de } \\
\text { atividades lúdicas } \\
\text { voltadas para uma } \\
\text { educação complexa, } \\
\text { trabalhando diretamente } \\
\text { seus conceitor no } \\
\text { processo ensino- } \\
\text { aprendizagem, } \\
\text { envolvendo a ludicidade } \\
\text { por meio de jogos e } \\
\text { brincadeiras que } \\
\text { conceituem a prática } \\
\text { pedagógica, a qual deve } \\
\text { se efetivar em sala de } \\
\text { aula, através de } \\
\text { estratégias que utilizem } \\
\text { materiais } \\
\text { contribuam para que o } \\
\text { ensino. }\end{array}$ \\
\hline 2 & $\begin{array}{l}\text { BARROS, J. L. C. et } \\
\text { al. }\end{array}$ & $\begin{array}{l}\text { O brincar das } \\
\text { crianças Sataré- } \\
\text { Mawé e suas } \\
\text { relações } \\
\text { interculturais com } \\
\text { a educação escolar } \\
\text { indígena }\end{array}$ & 2014 & 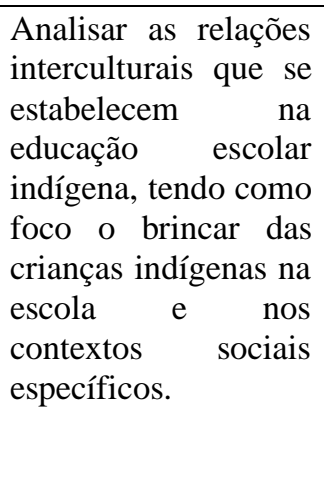 & $\begin{array}{l}\text { A educação das crianças } \\
\text { indígenas possui } \\
\text { características } \\
\text { diferenciadas, } \\
\text { constituindo um espaço } \\
\text { de trocas, respeito ao } \\
\text { modo de vida dos } \\
\text { indígenas, seus valores, } \\
\text { seus costumes e suas } \\
\text { brincadeirase, sobretudo } \\
\text { enquanto possibilidades } \\
\text { da interculturalidade. }\end{array}$ \\
\hline 3 & $\begin{array}{l}\text { DOMINGUES- } \\
\text { LOPES, et al. }\end{array}$ & $\begin{array}{l}\text { O lúdico em } \\
\text { questão: } \\
\text { brinquedos e } \\
\text { brincadeiras } \\
\text { indígenas }\end{array}$ & 2015 & $\begin{array}{l}\text { Versar } \\
\text { brinquedos, sobre } \\
\text { melhor, ou } \\
\text { lúdico-infantis, } \\
\text { encontlios } \\
\text { acervo etnográfico do } \\
\text { Laboratório do } \\
\text { Antropologia Arthur } \\
\text { Napoleão Figueiredo } \\
\text { da Universidade } \\
\text { Federal do Pará. }\end{array}$ & $\begin{array}{l}\text { O ato de brincar } \\
\text { evidencia a liberdade das } \\
\text { crianças indígenas no } \\
\text { processo de (re) } \\
\text { apropriação dos valores } \\
\text { culturais, entre os quais, } \\
\text { o "saber da criança" } \\
\text { mescla-se ao "saber } \\
\text { sobre a criança" para } \\
\text { construir a noção nativa } \\
\text { do "saber tornar-se } \\
\text { criança", condições } \\
\text { antropológicas que } \\
\text { reclamam a tradução } \\
\text { intercultural dos direitos } \\
\text { voltados às crianças } \\
\text { indígenas. }\end{array}$ \\
\hline 4 & SILVA, R. C. & $\begin{array}{c}\text { Participação e } \\
\text { aprendizagem na } \\
\text { educação da } \\
\text { criança indígena. }\end{array}$ & 2014 & $\begin{array}{l}\text { Estabelecer um } \\
\text { diálogo mais estreito } \\
\text { entre os campos da } \\
\text { educação e da } \\
\text { antropologia, no que } \\
\text { se refere a } \\
\text { investigação sobre a } \\
\text { aprendizagem da } \\
\text { criança indígena. }\end{array}$ & $\begin{array}{l}\text { Na ação e na } \\
\text { participação das crianças } \\
\text { em seu grupo familiar e } \\
\text { comunitário, reconhece- } \\
\text { se que os meninos } \\
\text { Xakriabá, na medida em } \\
\text { que aprendem, } \\
\text { desempenham um papel } \\
\text { fundamental nal }\end{array}$ \\
\hline
\end{tabular}




\begin{tabular}{|c|c|c|c|c|c|}
\hline & & & & & $\begin{array}{l}\text { manutenção do seu } \\
\text { próprio grupo. }\end{array}$ \\
\hline 5 & MELO, J. C. & $\begin{array}{l}\text { A função do lúdico } \\
\text { na transição da } \\
\text { educação infantil } \\
\text { para o primeiro ano } \\
\text { do ensino } \\
\text { fundamental }\end{array}$ & 2019 & 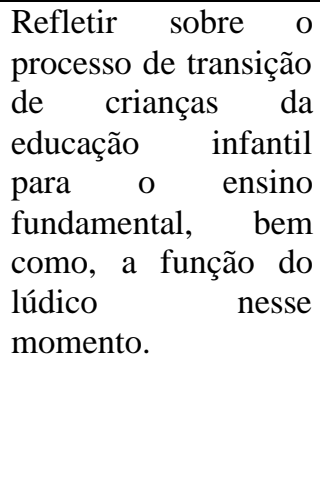 & $\begin{array}{l}\text { A promoção } \\
\text { atividades lúdicas no } \\
\text { processo de transição } \\
\text { entre a primeira e a } \\
\text { segunda etapa de } \\
\text { educação } \\
\text { contribui de forma } \\
\text { significativa para o } \\
\text { ensino e a aprendizagem } \\
\text { das crianças nos } \\
\text { aspectos cognitivo e } \\
\text { motor. }\end{array}$ \\
\hline 6 & $\begin{array}{l}\text { ANDRIOLLI, L. R.; } \\
\text { FAUSTINO, R. C. }\end{array}$ & $\begin{array}{c}\text { Vivências de } \\
\text { crianças indígenas } \\
\text { Kaingang na } \\
\text { cidade: elementos } \\
\text { para a } \\
\text { aprendizagem e o } \\
\text { desenvolvimento. }\end{array}$ & 2019 & $\begin{array}{lr}\text { Discutir } & \text { as } \\
\text { aprendizagens das } \\
\text { crianças, tanto na } \\
\text { instituição escolar de } \\
\text { Educação Infantil, na } \\
\text { terra indígena de } \\
\text { origem, como na } \\
\text { cidade, onde, } \\
\text { periodicamente, } \\
\text { vivenciam diversas } \\
\text { experiencias e } \\
\text { interações. }\end{array}$ & $\begin{array}{l}\text { Para os Kaingang, tanto } \\
\text { enviar as crianças } \\
\text { pequenas à escola, como } \\
\text { garantir a participação } \\
\text { delas em todas as } \\
\text { atividades familiares, } \\
\text { são ações importantes } \\
\text { pois representam } \\
\text { fecundos espaços de } \\
\text { aprendizagem a e } \\
\text { desenvolvimento infantil } \\
\text { indígena. }\end{array}$ \\
\hline 7 & PORTO, S. G. S. & $\begin{array}{l}\text { Ludicidade: um } \\
\text { caminho para } \\
\text { ressignificar a } \\
\text { prática pedagógica } \\
\text { e o } \\
\text { desenvolvimento } \\
\text { da criança na } \\
\text { educação infantil. }\end{array}$ & 2018 & $\begin{array}{lr}\text { Analisar } & \text { a } \\
\text { importância } & \text { da } \\
\text { ludicidade } & \text { na } \\
\text { aprendizagem e } & \text { no } \\
\text { desenvolvimento dos } \\
\text { alunos da } & \text { educação } \\
\text { infantil, } & \text { buscando } \\
\text { identificar } & \text { nos } \\
\text { estudos analisados de } \\
\text { que forma } & \text { as } \\
\text { atividades r lúdicas } \\
\text { auxiliam } & \text { no } \\
\text { aprendizado } & \text { dessas } \\
\text { crianças. } & \end{array}$ & $\begin{array}{l}\text { Observou-se que os } \\
\text { jogos, as brincadeiras e } \\
\text { os brinquedos tem uma } \\
\text { importância } \\
\text { fundamental } \\
\text { significativa } \\
\text { desenvolvimento } \\
\text { integral das crianças da } \\
\text { educação infantil, uma } \\
\text { vez que as atividades } \\
\text { lúdicas desenvolvem a } \\
\text { concentração, } \\
\text { criatividade, a } \\
\text { interações sociais, a } \\
\text { comunicação } \\
\text { aprendizado cognitivo } \\
\text { de forma prazerosa e } \\
\text { significativa. }\end{array}$ \\
\hline 8 & $\begin{array}{l}\text { TROQUEZ, M. C. } \\
\text { C. }\end{array}$ & $\begin{array}{l}\text { Educação infantil } \\
\text { na legislação e na } \\
\text { produção do } \\
\text { conhecimento }\end{array}$ & 2016 & \begin{tabular}{lr}
\multicolumn{2}{l}{ Investigar } \\
pressupostos legais e \\
teóricos & sobre a \\
educação & infantil \\
indígena, & como \\
primeira & etapa da \\
educação & básica \\
nacional. &
\end{tabular} & $\begin{array}{l}\text { A pesquisa evidenciou, } \\
\text { entre outros resultados, } \\
\text { que, embora a educação } \\
\text { infantil seja um direito } \\
\text { subjetivo da criança, } \\
\text { para a educação indígena } \\
\text { é facultativar } \mathrm{Na} \\
\text { produção } \\
\text { conhecimento, do } \\
\text { evidenciou grande } \\
\text { contribuição de estudos } \\
\text { da antropologia da } \\
\text { criança para o } \\
\text { conhecimento das } \\
\text { especificidades das } \\
\text { crianças em diferentes }\end{array}$ \\
\hline
\end{tabular}




\begin{tabular}{|c|c|c|c|c|c|}
\hline & & & & & $\begin{array}{l}\text { grupos étnicos. Contudo, } \\
\text { no que diz respeito à } \\
\text { especificidade } \\
\text { educação de crianças } \\
\text { indígenas } \\
\text { instituições de educação } \\
\text { infantil, o estufo aponta } \\
\text { muitas questões para o } \\
\text { debate/estudos e } \\
\text { evidencia a necessidade } \\
\text { de pesquisas de campo } \\
\text { para o conhecimento de } \\
\text { cada realidade e das } \\
\text { demandas por educação } \\
\text { infantil de acordo com } \\
\text { cada povo ou grupo } \\
\text { étnico. }\end{array}$ \\
\hline 9 & GRANDO, B. S. & $\begin{array}{c}\text { Infância, } \\
\text { brincadeiras e } \\
\text { brinquedos em } \\
\text { comunidades } \\
\text { indígenas } \\
\text { brasileiras }\end{array}$ & 2014 & 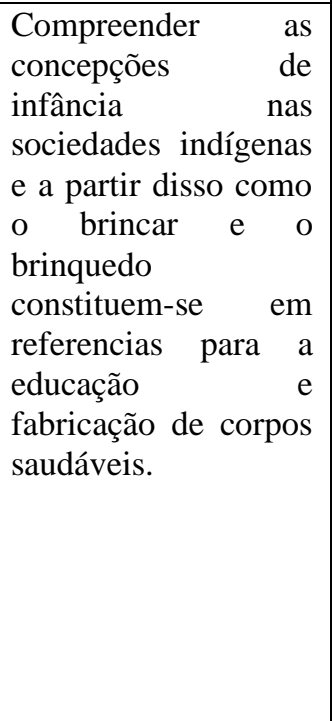 & $\begin{array}{l}\text { No processo de aprender } \\
\text { e ensinar, o brincar é } \\
\text { parte do reconhecimento } \\
\text { da autonomia da criança } \\
\text { e estão atrelados ao } \\
\text { papel que esta assume na } \\
\text { sociabilidade e } \\
\text { mediação pertinentes ao } \\
\text { seu grupo social. Neste } \\
\text { processo, aparentemente } \\
\text { despretensioso e lúdico, } \\
\text { a criança vai dando } \\
\text { sentido e significado a } \\
\text { sua forma única de ser e } \\
\text { estar no mundo, como } \\
\text { parte de uma cosmologia } \\
\text { que é própria de cada } \\
\text { sociedade indígena. }\end{array}$ \\
\hline 10 & $\begin{array}{l}\text { ALMEIDA, J. A. et } \\
\text { al. }\end{array}$ & $\begin{array}{c}\text { Infância e } \\
\text { educação infantil } \\
\text { indígena: um } \\
\text { estudo da criança } \\
\text { Apinajé }\end{array}$ & 2017 & $\begin{array}{l}\text { Conhecer a ação das } \\
\text { escolas dessas } \\
\text { aldeias, alcançando } \\
\text { as práticas } \\
\text { pedagógicas, } \\
\text { currículo e a relação } \\
\text { professor-aluno, em } \\
\text { duas classes de } \\
\text { alfabetização, } \\
\text { considerando o valor } \\
\text { da cultura desse } \\
\text { povo, também dentro } \\
\text { da educação escolar. }\end{array}$ & $\begin{array}{l}\text { As escolas precisam } \\
\text { estabelecer relações } \\
\text { mais estreitas com a vida } \\
\text { e o cotidiano da aldeia. E } \\
\text { as práticas culturais das } \\
\text { crianças, nomeadamente } \\
\text { folguedos e brincadeiras, } \\
\text { podem ser aportes } \\
\text { facilitadores de uma } \\
\text { educação diferenciada, } \\
\text { considerando ser esta } \\
\text { uma conquista dos povos } \\
\text { indígenas brasileiros, } \\
\text { garantida por } \\
\text { instrumentos jurídicos } \\
\text { nacionais } \\
\text { internacionais. }\end{array}$ \\
\hline 11 & GRANDO, B. S. & $\begin{array}{c}\text { Educação da } \\
\text { criança indígena e } \\
\text { educação infantil } \\
\text { em Mato Grosso: } \\
\text { uma questão para o } \\
\text { debate }\end{array}$ & 2016 & $\begin{array}{lrr}\text { Refletir } & \text { sobre } & \text { a } \\
\text { educação } & \text { escolar } \\
\text { indígena e } & \text { sua relação } \\
\text { com a } & \text { educação } \\
\text { pretendida } & \text { por } & \text { cada } \\
\text { povo, } & & \\
\text { problematizando as } \\
\text { políticas }\end{array}$ & $\begin{array}{l}\text { Ficou evidenciado nos } \\
\text { estudos o protagonismo } \\
\text { e autonomia da criança a } \\
\text { partir das formas de } \\
\text { educar e garantir a vida } \\
\text { coletiva como um direito } \\
\text { coletivo dos povos } \\
\text { indígenas, explicitados }\end{array}$ \\
\hline
\end{tabular}




\begin{tabular}{|c|c|c|c|c|c|}
\hline & & & & $\begin{array}{llr}\text { educacionais } & \text { e } & \text { a } \\
\text { formação } & & \text { de } \\
\text { professores. } & & \\
\end{array}$ & $\begin{array}{l}\text { na Constituição } \\
\text { brasileira e na LDB. }\end{array}$ \\
\hline 12 & $\begin{array}{l}\text { FIGUEIREDO, L. } \\
\text { M. S.; AZEVEDO, } \\
\text { L. F. }\end{array}$ & $\begin{array}{c}\text { Jogos e } \\
\text { brincadeiras } \\
\text { indígenas em Mato } \\
\text { Grosso }\end{array}$ & 2014 & $\begin{array}{lr}\text { Descrever e refletir } \\
\text { sobre jogos } \\
\text { brincadeiras } \\
\text { Estado do } \\
\text { Grosso. }\end{array}$ & $\begin{array}{l}\text { As brincadeiras infantis } \\
\text { nas culturas indígenas de } \\
\text { Mato Grosso mostram o } \\
\text { aprendizado do contexto } \\
\text { (cultural e físico) como } \\
\text { fatores formadores de } \\
\text { identidades em cada } \\
\text { etnia, por meio de jogos } \\
\text { e brincadeiras. }\end{array}$ \\
\hline 13 & SILVA, M. et al. & $\begin{array}{l}\text { Brinquedos e } \\
\text { brincadeiras } \\
\text { indígenas } \\
\text { Kaingangs: } \\
\text { transfiguração } \\
\text { entre gerações }\end{array}$ & 2015 & $\begin{array}{l}\text { Diagnosticar } \\
\text { brinquedos } \\
\text { brincadeiras antigas } \\
\text { que os indígenas } \\
\text { Kaingangs da aldeia } \\
\text { Pinhalzinho tinham } \\
\text { na época de criança e } \\
\text { as mudanças que } \\
\text { ocorreram para os } \\
\text { dias atuais. }\end{array}$ & $\begin{array}{l}\text { As respostas indicaram } \\
\text { que os brinquedos, que } \\
\text { antes eram } \\
\text { confeccionados, } \\
\text { passaram a ser } \\
\text { substituídos por } \\
\text { brinquedos comprados } \\
\text { nos centros urbanos. } \\
\text { Observou-se também } \\
\text { que a brincadeira de } \\
\text { maior popularidade na } \\
\text { comunidade estudada foi } \\
\text { o futebol, com a } \\
\text { mudança que atualmente } \\
\text { é jogado com maior } \\
\text { competitividade. } \\
\text { Através dos resultados, } \\
\text { percebeu-se que com o } \\
\text { contato com os } \\
\text { brinquedos tecnológicos } \\
\text { o Kaingang vem } \\
\text { perdendo costumes que } \\
\text { eram passados de } \\
\text { geração a } \\
\text { consequentemente, } \\
\text { dissipando sua cultura. }\end{array}$ \\
\hline 14 & RODRIGUES, W. & $\begin{array}{l}\text { Relacionando } \\
\text { ludicidade e } \\
\text { matemática na } \\
\text { infância indígena }\end{array}$ & 2018 & $\begin{array}{l}\text { Relacionar as } \\
\text { brincadeiras das } \\
\text { crianças indígenas, os } \\
\text { conceitos sobre } \\
\text { ludicidade e algumas } \\
\text { noções matemáticas } \\
\text { básicas utilizadas } \\
\text { pelas crianças. }\end{array}$ & $\begin{array}{l}\text { A introdução de } \\
\text { conceitos matemáticos } \\
\text { na vida de crianças } \\
\text { indígenas da primeira } \\
\text { infância pode ajudar no } \\
\text { desenvolvimento } \\
\text { intelectual, emocional e } \\
\text { social de tais crianças. } \\
\text { Ela ainda pode ajudar na } \\
\text { tomada de decisões, na } \\
\text { compreensão de } \\
\text { determinados padrões e } \\
\text { na realização de diversas } \\
\text { atividades cotidianas. }\end{array}$ \\
\hline 15 & $\begin{array}{l}\text { MOTA, L. K. L.; } \\
\text { RAMIRES, C. R. }\end{array}$ & $\begin{array}{l}\text { Educação infantil } \\
\text { indígena e a } \\
\text { ludicidade: a } \\
\text { percepção de } \\
\text { agentes escolares } \\
\text { na aprendizagem } \\
\text { da criança }\end{array}$ & 2018 & $\begin{array}{l}\text { Compreender } \\
\text { percepção de pais e } \\
\text { professores sobre a } \\
\text { importância da arte } \\
\text { lúdica no processo } \\
\text { aprendizagem na } \\
\text { educação infantil } \\
\text { indígena em pré- }\end{array}$ & 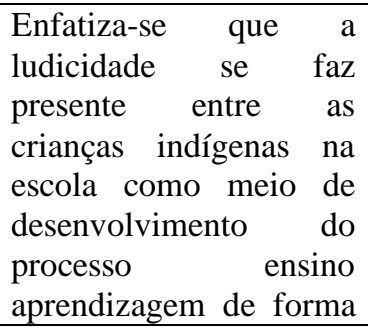 \\
\hline
\end{tabular}




\begin{tabular}{|c|c|c|c|c|c|}
\hline & & & & $\begin{array}{lr}\text { escola } & \text { na } \\
\text { comunidade indígena } \\
\text { Ticuna de Porto } \\
\text { Cordeirinho r em } \\
\text { Benjamin Constant - } \\
\text { AM. }\end{array}$ & $\begin{array}{l}\text { mais prazerosa. Mas, a } \\
\text { ludicidade apesar de } \\
\text { estar amparada } \\
\text { legalmente nas políticas } \\
\text { públicas educacionais } \\
\text { ainda é pouco praticada } \\
\text { na educação infantil } \\
\text { indígena. }\end{array}$ \\
\hline 16 & $\begin{array}{l}\text { RAMIRES, C. R.; } \\
\text { MOTA, L. K. L. }\end{array}$ & $\begin{array}{l}\text { Educação infantil } \\
\text { indígena e a } \\
\text { formação de } \\
\text { professores: } \\
\text { aspectos legais e a } \\
\text { importância da } \\
\text { qualidade } \\
\text { educacional pré- } \\
\text { escolar na voz } \\
\text { docente }\end{array}$ & 2018 & 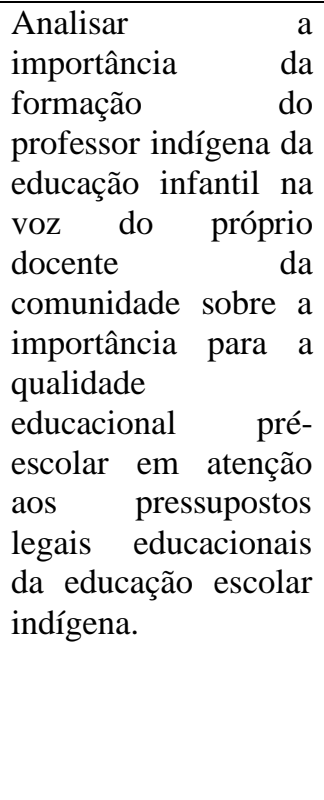 & $\begin{array}{l}\text { Os resultados versam } \\
\text { sobre o interesse da } \\
\text { comunidade indígena } \\
\text { em querer a educação } \\
\text { infantil na comunidade, } \\
\text { mesmo a educação } \\
\text { infantil sendo opcional } \\
\text { de acordo com os } \\
\text { parâmetros } \\
\text { constitucionais legais. } \\
\text { Os professores tem } \\
\text { interesse e há } \\
\text { necessidade de formação } \\
\text { inicial, continuada e em } \\
\text { serviço para o professor } \\
\text { indígena, tendo em vista } \\
\text { a melhoria da qualidade } \\
\text { da educação infantil no } \\
\text { contexto indígena } \\
\text { Ticuna. }\end{array}$ \\
\hline 17 & CONTI, K. C. et al. & $\begin{array}{l}\text { Criação de jogos } \\
\text { no contexto } \\
\text { indígena: o cabo de } \\
\text { guerra numérico }\end{array}$ & 2017 & $\begin{array}{l}\text { Descrever a criação } \\
\text { de um jogo, o cabo de } \\
\text { guerra numérico, por } \\
\text { um dos estudantes do } \\
\text { curso de formação } \\
\text { intercultural de } \\
\text { educadores } \\
\text { indígenas, habilitação } \\
\text { em matemática, da } \\
\text { UFMG. }\end{array}$ & $\begin{array}{l}\text { Por apresentar jogadas } \\
\text { que exigiam estratégias } \\
\text { matemáticas o jogo } \\
\text { mostrou-se uma } \\
\text { possibilidade } \\
\text { interessante para o } \\
\text { ensino de matemática e } \\
\text { também um canal para a } \\
\text { avaliação dos saberes e } \\
\text { das práticas indígenas. }\end{array}$ \\
\hline 18 & $\begin{array}{l}\text { FAUSTINO, K. C.; } \\
\text { MOTA, L. T. }\end{array}$ & $\begin{array}{l}\text { Crianças indígenas: } \\
\text { o papel dos jogos, } \\
\text { das brincadeiras e } \\
\text { da imitação na } \\
\text { aprendizagem e no } \\
\text { desenvolvimento. }\end{array}$ & 2016 & $\begin{array}{l}\text { Apresentar e discutir } \\
\text { alguns estudos atuais } \\
\text { referentes à infância } \\
\text { indígena } \\
\text { experiências } \\
\text { registradas de ações } \\
\text { desenvolvidas junto } \\
\text { aos Kaingang, } \\
\text { Guarani e Xetá no } \\
\text { Estado do Paraná no } \\
\text { período de } 2012 \text { a } \\
\text { 2014. }\end{array}$ & $\begin{array}{l}\text { A maneira como é } \\
\text { pensada, planejada e } \\
\text { conduzida a educação } \\
\text { escolar indígena, de } \\
\text { forma geral no Brasil, } \\
\text { destina pouco espaço } \\
\text { para serem considerado } \\
\text { os saberes e as vivencias } \\
\text { das crianças, suas } \\
\text { brincadeiras, suas } \\
\text { diferentes maneiras de } \\
\text { interação } \\
\text { aprendizagem. }\end{array}$ \\
\hline 19 & $\begin{array}{l}\text { SANTANA, F. M. } \\
\text { N. et al. }\end{array}$ & $\begin{array}{l}\text { Ludicidade e o } \\
\text { contexto cultural } \\
\text { diversificado: } \\
\text { contribuições e } \\
\text { desafios no } \\
\text { processo ensinar e } \\
\text { aprender }\end{array}$ & 2016 & $\begin{array}{l}\text { Tratar sobre a } \\
\text { ludicidade no } \\
\text { processo do aprender, } \\
\text { reunindo dados que } \\
\text { indiquem conceitos e } \\
\text { concepções sobre o } \\
\text { tema proposto. }\end{array}$ & $\begin{array}{l}\text { Dos resultados } \\
\text { apresentados destacam- } \\
\text { se o conceito e a } \\
\text { relevância da ludicidade } \\
\text { no processo educacional } \\
\text { como meio de revitalizar } \\
\text { a própria cultura na qual } \\
\text { o educando está } \\
\text { inserido. }\end{array}$ \\
\hline
\end{tabular}




\begin{tabular}{|c|c|c|c|c|c|}
\hline 20 & LUCKESI, C. & $\begin{array}{l}\text { Ludicidade e } \\
\text { formação do } \\
\text { educador }\end{array}$ & 2014 & $\begin{array}{l}\text { Apresentar o trabalho } \\
\text { de dois temas: o que é } \\
\text { ludicidade e a } \\
\text { formação do } \\
\text { educador para ensinar } \\
\text { de modo lúdico. }\end{array}$ & $\begin{array}{l}\text { Ludicidade é } \\
\text { compreender como } \\
\text { experiencia interna de } \\
\text { inteireza e plenitude por } \\
\text { parte do sujeito. Para } \\
\text { ensinar ludicamente, o } \\
\text { educador necessita } \\
\text { cuidar-se } \\
\text { emocionalmente e, } \\
\text { cognitivamente, adquirir } \\
\text { as habilidades } \\
\text { necessárias para } \\
\text { conduzir o ensino de tal } \\
\text { forma que subsidie uma } \\
\text { aprendizagem lúdica.55 }\end{array}$ \\
\hline 21 & CONTI, K. C. et al. & $\begin{array}{l}\text { Uso de jogos } \\
\text { matemáticos como } \\
\text { proposta } \\
\text { pedagógica num } \\
\text { contexto de } \\
\text { formação } \\
\text { intercultural para } \\
\text { professores } \\
\text { indígenas }\end{array}$ & 2018 & $\begin{array}{l}\text { Descrever } \\
\text { utilização do jogo } \\
\text { trinca-espinhas e a } \\
\text { criação do jogo cabo } \\
\text { de guerra numérica. }\end{array}$ & $\begin{array}{l}\text { As descrições dos jogos } \\
\text { foram realizadas a partir } \\
\text { de alguns momentos que } \\
\text { analisamos serem } \\
\text { produtivos durante as } \\
\text { aulas na universidade e } \\
\text { no território indígena. } \\
\text { Nesse sentido, } \\
\text { consideramos que essas } \\
\text { atividades } \\
\text { oportunizaram } \\
\text { momentos } \\
\text { aprendizagem a partir de } \\
\text { uma abordagem criativa, } \\
\text { lúdica e divertida. }\end{array}$ \\
\hline 22 & $\begin{array}{l}\text { PINHO, V. } \\
\text { TOMA; } \\
\text { M. }\end{array}$ & $\begin{array}{l}\text { Infâncias, saberes e } \\
\text { diversidade: um } \\
\text { diálogo com a } \\
\text { educação infantil }\end{array}$ & 2017 & $\begin{array}{l}\text { Abordar o tema da } \\
\text { educação infantil na } \\
\text { perspectiva mais } \\
\text { ampla da democracia, } \\
\text { da diversidade de } \\
\text { populações infantis e } \\
\text { de saberes sobre elas. }\end{array}$ & $\begin{array}{l}\text { Preconiza-se que a } \\
\text { educação infantil de } \\
\text { crianças negras e } \\
\text { indígenas, } \\
\text { principalmente, deve } \\
\text { servir ao propósito de } \\
\text { efetivação da educação } \\
\text { democrática como } \\
\text { garantida do acesso } \\
\text { universal, da qualidade } \\
\text { das práticas educativas e } \\
\text { da garantia dos direitos à } \\
\text { diversidade de } \\
\text { experiências sociais e da } \\
\text { diferença, dispondo-se a } \\
\text { desnudar a sua história e } \\
\text { valorizar a sua cultura } \\
\text { com os sentidos de } \\
\text { ser/pertencer no diálogo } \\
\text { da e para a diversidade. }\end{array}$ \\
\hline 23 & MARTINS, R. et al. & $\begin{array}{c}\text { O resgate das } \\
\text { memorias do jogo } \\
\text { e brincadeiras de } \\
\text { uma comunidade } \\
\text { indígena }\end{array}$ & 2019 & $\begin{array}{l}\text { Identificar o resgate } \\
\text { das atividades físicas } \\
\text { de lazer entre pais e } \\
\text { filhos de uma } \\
\text { comunidade } \\
\text { indígena. }\end{array}$ & $\begin{array}{l}\text { Foi possível constatar } \\
\text { que os jogos e } \\
\text { brincadeiras recordados } \\
\text { por jovens indígenas e } \\
\text { com descendência são } \\
\text { diferentes das atividades } \\
\text { culturais desta } \\
\text { comunidade de } \\
\text { atualmente. Os jovens da } \\
\text { geração atual, tem pouco }\end{array}$ \\
\hline
\end{tabular}




\begin{tabular}{|c|c|c|c|c|c|}
\hline & & & & & $\begin{array}{l}\text { conhecimento e prática } \\
\text { de jogos e brincadeiras } \\
\text { de sua própria cultura, } \\
\text { assim como de outras } \\
\text { etnias brasileiras. }\end{array}$ \\
\hline 24 & $\begin{array}{l}\text { BERGAMASCHI, } \\
\text { M. A.; MENEZES, } \\
\text { A. L. T. }\end{array}$ & $\begin{array}{l}\text { Crianças indígenas, } \\
\text { educação, escola e } \\
\text { interculturalidade }\end{array}$ & 2016 & $\begin{array}{l}\text { Apresentar reflexões } \\
\text { produzidas a partir da } \\
\text { convivência com o } \\
\text { povo Guarani, } \\
\text { buscando } \\
\text { compreender seus } \\
\text { processos próprios de } \\
\text { educação r que } \\
\text { envolvem as crianças } \\
\text { e são responsáveis } \\
\text { pela formação da } \\
\text { pessoa. }\end{array}$ & $\begin{array}{l}\text { Constatou-se uma } \\
\text { educação que considera } \\
\text { a dimensão espiritual, a } \\
\text { dimensão coletiva de } \\
\text { uma comunidade que se } \\
\text { mostra implicada como a } \\
\text { formação da pessoa e } \\
\text { uma dimensão } \\
\text { individual, em que cada } \\
\text { um se responsabiliza por } \\
\text { si, imbuído por uma } \\
\text { busca e por um } \\
\text { caminhar. }\end{array}$ \\
\hline 25 & $\begin{array}{ll}\text { MELO, } & \text { A.; } \\
\text { RIBEIRO, D. } & \end{array}$ & $\begin{array}{l}\text { Interculturalidade e } \\
\text { educação infantil: } \\
\text { reflexões sobre } \\
\text { diferenças culturais } \\
\text { na infância }\end{array}$ & 2019 & $\begin{array}{l}\text { Apresentar } \\
\text { interculturalidade } \\
\text { crítica } \\
\text { ferramenta } \\
\text { pedagógica que deve } \\
\text { ser central na } \\
\text { constituição dos } \\
\text { cenários e contextos } \\
\text { em educação infantil. }\end{array}$ & $\begin{array}{l}\text { Construir práticas } \\
\text { pedagógicas } \\
\text { interculturais, } \\
\text { educação infantil, leva a } \\
\text { ampliar o olhar para a } \\
\text { diversidade de culturas } \\
\text { da sociedade e não } \\
\text { apenas de cada turma. } \\
\text { Traz implicações ao } \\
\text { currículo e a toda a } \\
\text { organização } \\
\text { institucional, pois a } \\
\text { diversidade deve ser o } \\
\text { eixo que permeia tudo } \\
\text { acontece nas instituições } \\
\text { educativas e não ser } \\
\text { apenas um adendo que } \\
\text { deve ser trabalhado de } \\
\text { vez em quando. }\end{array}$ \\
\hline 26 & $\begin{array}{l}\text { GODOY, } \\
\text { FERREIRA, E. }\end{array}$ & $\begin{array}{c}\text { O universo cultural } \\
\text { da criança Guarani } \\
\text { Mbya e a presença } \\
\text { dos centros } \\
\text { educacionais e } \\
\text { culturais indígenas }\end{array}$ & 2014 & $\begin{array}{l}\text { Descrever o universo } \\
\text { cultural da criança } \\
\text { Guarani Mbya e a } \\
\text { presença dos centros } \\
\text { educacionais e e } \\
\text { culturas indígenas } \\
\text { cecis, nas aldeias de } \\
\text { São Paulo. }\end{array}$ & 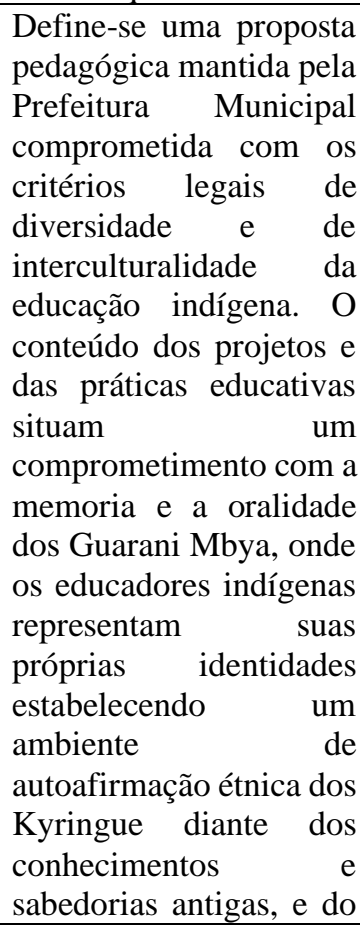 \\
\hline
\end{tabular}




\begin{tabular}{|c|c|c|c|c|c|}
\hline & & & & & $\begin{array}{l}\text { mundo vivido por seus } \\
\text { ancestrais. } \\
\text { experiencias do } \\
\text { letramento e do mundo } \\
\text { regido pela escrita são } \\
\text { consideradas como } \\
\text { importantes } \\
\text { necessárias, no convívio } \\
\text { como não-indio e com } \\
\text { um meio de progresso } \\
\text { para os aprendizes. }\end{array}$ \\
\hline 27 & $\begin{array}{l}\text { DELLE PIAGGE, } \\
\text { A. C. M. et al. }\end{array}$ & $\begin{array}{l}\text { Reflexes acerca da } \\
\text { boneca indígena: } \\
\text { educação escolar, } \\
\text { diversidade e } \\
\text { infâncias. }\end{array}$ & 2019 & $\begin{array}{l}\text { Sistematizar } \\
\text { conhecimentos e } \\
\text { estratégias sobre a } \\
\text { utilização da boneca } \\
\text { indígena Rtixókó. }\end{array}$ & $\begin{array}{l}\text { A diversidade contribui } \\
\text { para a excelência de } \\
\text { processos educativos nas } \\
\text { práticas sociais e } \\
\text { pedagógicos, por gerar } \\
\text { espaços de convivência } \\
\text { que possibilitam tornar a } \\
\text { escola um espaço que } \\
\text { assuma as diferenças } \\
\text { existentes, construa } \\
\text { relações novas e que } \\
\text { sejam verdadeiramente } \\
\text { igualitárias, } \\
\text { compreender valores, } \\
\text { que podem fortalecer e } \\
\text { potencializar a condução } \\
\text { da vida. No entanto, criar } \\
\text { oportunidades } \\
\text { aprendizagens de } \\
\text { ensinamentos por meio } \\
\text { de bonecas plurais, } \\
\text { oportunizam a } \\
\text { construção do respeito a } \\
\text { diversidade è diferença } \\
\text { a partir da ludicidade e } \\
\text { das brincadeiras. }\end{array}$ \\
\hline 28 & $\begin{array}{l}\text { JANKAUSKAS, R. } \\
\text { M. B. et al. }\end{array}$ & $\begin{array}{l}\text { A educação infantil } \\
\text { na escola indígena } \\
\text { na comunidade de } \\
\text { Umariaçu II }\end{array}$ & 2015 & $\begin{array}{l}\text { Investigar como se dá } \\
\text { o processo de ensino } \\
\text { e aprendizagem na } \\
\text { educação infantil, na } \\
\text { escola municipal } \\
\text { AEGATU } \\
\text { DECATUCU, } \\
\text { debatendo } \\
\text { analiticamente as } \\
\text { relações indígenas e } \\
\text { não indígenas no } \\
\text { contexto educativo. }\end{array}$ & $\begin{array}{l}\text { As crianças Tikuna, tem } \\
\text { seu momento de } \\
\text { diversão, e em relação à } \\
\text { aprendizagem, res os } \\
\text { mesmos são muitos } \\
\text { atenciosos quando os } \\
\text { educadores estão a } \\
\text { explicar. Os pais não são } \\
\text { tão colaboradores da } \\
\text { educação dos filhos, } \\
\text { pois, ainda possuem a } \\
\text { ideia de que o } \\
\text { ensinamento e a } \\
\text { aprendizagem são } \\
\text { heranças marcadas e } \\
\text { enraizadas pelas } \\
\text { gerações familiares. Por } \\
\text { sua vez, para os } \\
\text { educadores a escola é a } \\
\text { instituição que tende a } \\
\text { viabilizar maitas } \\
\text { atividades para ter a }\end{array}$ \\
\hline
\end{tabular}




\begin{tabular}{|c|c|c|c|c|c|}
\hline & & & & & $\begin{array}{l}\text { presença dos pais no seu } \\
\text { cotidiano, mesmo frente } \\
\text { aos desafios que a } \\
\text { educação indígena } \\
\text { enfrenta nos currículos, } \\
\text { nos recursos, na } \\
\text { comunidade, sempre } \\
\text { com uma tendência de } \\
\text { aculturação da vida } \\
\text { social a qual a cada dia é } \\
\text { infiltrada por uma } \\
\text { sociedade mais } \\
\text { urbanizada. }\end{array}$ \\
\hline 29 & $\begin{array}{l}\text { IVES-FELIX, N. O.; } \\
\text { NAKAYAMA, L. }\end{array}$ & $\begin{array}{l}\text { A danada da escola } \\
\text { está lá: educação } \\
\text { infantil vivenciada } \\
\text { pelas crianças } \\
\text { indígenas Tentehar } \\
\text { maranhenses, a } \\
\text { partir das falas dos } \\
\text { seus interlocutores }\end{array}$ & 2018 & $\begin{array}{l}\text { Investigar o processo } \\
\text { de educação infantil } \\
\text { vivenciado pelas } \\
\text { pessoas que fazem a } \\
\text { pré-escola municipal } \\
\text { indígena Maíra-ira. }\end{array}$ & $\begin{array}{l}\text { A educação infantil } \\
\text { ainda está fortemente } \\
\text { arraigada às bases } \\
\text { epistemológicas de um } \\
\text { currículo eurocêntrico, } \\
\text { portanto, a prática do } \\
\text { professor bilingue é } \\
\text { fundamental na } \\
\text { interação professor não } \\
\text { indígena e as crianças, } \\
\text { funcionando como uma } \\
\text { porta para a valorização } \\
\text { das tradições e da lingua } \\
\text { Tentehar. A educação } \\
\text { ofertada ainda não se } \\
\text { configura plenamente } \\
\text { em um diálogo } \\
\text { contextualizado entre os } \\
\text { saberes ocidentais e os } \\
\text { tradicionais, uma vez } \\
\text { que a cultura Tentehar } \\
\text { não está sendo nem o } \\
\text { ponto de partida nem o } \\
\text { de chegada, do currículo } \\
\text { vivenciado. }\end{array}$ \\
\hline 30 & $\begin{array}{l}\text { TENÓRIO, J. G.; } \\
\text { SILVA, C. L. }\end{array}$ & $\begin{array}{c}\text { As práticas } \\
\text { corporais indígenas } \\
\text { como conteúdo da } \\
\text { educação física } \\
\text { escolar }\end{array}$ & 2014 & $\begin{array}{l}\text { Conhecer as } \\
\text { diferentes práticas } \\
\text { corporais indígenas e } \\
\text { refletir sobre sua } \\
\text { aplicação nas aulas de } \\
\text { educação física. }\end{array}$ & 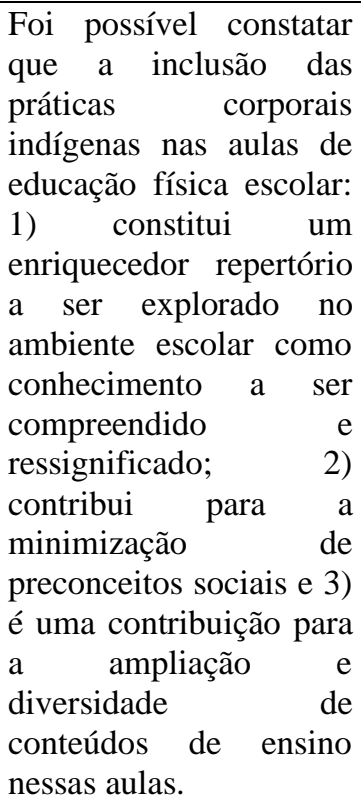 \\
\hline
\end{tabular}

Fonte: Elaborado pela autora. 
Referente à análise dos trabalhos científicos investigados o presente estudo se desdobrou na organização de três categorias gerais, conforme apresentadas a seguir.

\section{A Utilização da Ludicidade Como Recurso Pedagógico na Sala de aula}

A ludicidade (representada pelos jogos e brincadeiras) faz parte da vida da criança, sendo fundamental para o desenvolvimento de sua autonomia e identidade, visto que através das brincadeiras a criança pode desenvolver a percepção, atenção e repetição.

De acordo com Santana et al (2016, p. 39), “a ludicidade está presente na vida de toda criança independentemente da época, cultura ou classe social como fator indispensável à saúde física, emocional e intelectual". Assim, quando inserida no âmbito escolar a ludicidade pode motivar o desenvolvimento da concentração, conhecimento, linguagem e a socialização ao interagir e experimentar normas e papeis sociais, "esses fatores quando bem desenvolvidos contribuirão para a eficiência e o equilíbrio da pessoa adulta" (SANTANA ET AL, 2016, p. 39).

O conceito de ludicidade e a importância do brincar vem permeando o desenvolvimento infantil e tem contribuído significativamente para aprimorar a inteligência, a socialização e as habilidades psicomotoras das crianças. Sua concepção foi variando conforme a cultura ou o período histórico no qual estava inserido.

Fazendo uma análise semântica e etimológica da palavra 'ludus' que significa jogo, Antunes e Batista (2017. p. 3) afirmam que "a evolução semântica superou suas limitações de jogo para se tornar uma atividade satisfatória e com significado, podendo ser definida conforme seu tipo, como jogo, dramatização, mimica, dança de cantiga de roda entre outras, e segundo uma teorização na área da educação".

Sob a perspectiva educacional a atividade lúdica é considerada como o berço obrigatório das atividades intelectuais da criança. Esta não é apenas uma forma de alívio ou passatempo para gastar energia das crianças, mas um meio que colabora e enriquece o desenvolvimento intelectual.

Nesse aspecto, ao ser utilizada em sala de aula, a ludicidade torna-se então um meio para a realização dos objetivos educacionais onde "os professores devem desenvolver o trabalho com materiais concretos e jogos lúdicos, onde as crianças possam manusear os brinquedos, refletir e reorganizar, sua aprendizagem, contextualizando as atividades de forma mais complexa e com mais facilidade e entusiasmo..." (ANTUNES e BATISTA, 2017, p. 4) 
Existe uma frequente associação entre a ludicidade e diversão, porém se faz necessário destacar que uma atividade lúdica não necessariamente precisa ser divertida, visto que mais importante que a diversão ou o prazer em si é a sensação de plenitude que se tem ao realizar uma atividade lúdica. Segundo Antunes e Batista (2017, p. 7) "na sala de aula o lúdico enriquece $\mathrm{o}$ aprendizado da criança $\mathrm{e}$ transforma suas ações em resultados complexos para o seu desenvolvimento enquanto aluno...". Dessa forma, a ludicidade "torna-se uma ponte que auxilia na melhoria dos resultados por parte dos educadores interessados em promover mudanças no aprendizado" (ANTUNES e BATISTA, 2017, p. 7).

Deve estar claro também, que as atividades lúdicas, incluindo jogos e brincadeiras, não apresentam uma característica universal e atemporal, pois são cingidas pela cultura e pelo momento sócio histórico em que se desenvolvem. Pode-se afirmar, então, que a cultura intermedeia todas as relações humanas e interfere significativamente em práticas sociais, rotinas, valores, costumes, linguagens, objetos e instrumentos.

A criança já nasce imersa em um mundo social e cultural e o interpreta por meio de suas experiências, de suas relações com os adultos e do ambiente em que está inserida. Para Santana et al (2016, p. 42) "o brincar está intrinsecamente no contexto cultural das crianças, pois muitas brincadeiras apresentam características do lugar onde estão situadas".

Com isso, entende-se que as experiencias lúdicas vivenciadas na infância são extremadas pelas influências culturais, o que se presume que o ato de brincar pode ser comum a todas as culturas, mas as brincadeiras e os brinquedos são distintos. Felizmente, a humanidade preservou uma intensa diversidade cultural em que é possível observar os mais variados aspectos lúdicos que desenham a infância de muitas comunidades e nações do planeta.

Nesse sentido nas palavras de Antunes e Batista (2017, p. 7), “as atividades lúdicas possibilitam a incorporação de valores, o desenvolvimento cultural, assimilação de novos conhecimentos, o desenvolvimento da sociabilidade da criatividade".

Considerando que na Educação Infantil as crianças precisam adquirir conhecimentos significativos para a sua formação, tais como: cognição, motricidade dentre outros. Compreende-se que, dependendo de como o trabalho pedagógico é desenvolvido nessas áreas a brincadeira enquanto componente escolar pode contribuir de maneira significativa no processo formativo da criança. 
Nesse contexto a brincadeira auxilia no processo de aprendizagem infantil como uma maneira do professor perceber o aluno em uma perspectiva cognitiva, afetiva, psicomotora e social. Desse modo a brincadeira pode ser vista como a ação que a criança desempenha ao concretizar as regras do jogo ao mergulhar na ação lúdica. É possível afirmar, portanto, que a brincadeira é o lúdico em ação. Antunes e Batista (2017, p. 7) afirmam que "a brincadeira também trabalha de forma gradativa o equilíbrio cognitivo das crianças contribuindo no processo de conhecimento as quais vem a apropriar-se dos signos sociais [...]".

Assim, a brincadeira torna-se a forma mais privilegiada de aprendizagem. Tendo em vista que à medida que vão crescendo, as crianças trazem para suas brincadeiras o que veem, escutam, observam e experimentam. O jogo permite a aprendizagem da criança e o seu completo desenvolvimento, já que conta com teores do dia-a-dia, como as normas, as interações com objetos e o meio e a variedade de linguagens envolvidas em sua prática.

Desse modo, fundamentando-se no pressuposto de que a prática pedagógica pode proporcionar alegria às crianças no procedimento de aprendizagem, a ludicidade deve ser levada a sério na escola, proporcionando-se o aprender por meio do jogo e, logo, o aprender brincando. Pode-se deduzir, assim que a formação lúdica do professor favorece essa prática. Segundo Luckesi (2014, p. 22), é importante que o professor "esteja internamente pleno e bem, à medida que lidera os educandos em sua aprendizagem". É possível entender que a ludicidade propicia o trabalho com diferentes linguagens, o que facilita a transposição e a representação de conceitos elaborados pelo adulto para as crianças.

Educar nessa perspectiva, é ir além da transmissão de informações ou de colocar à disposição da criança apenas um caminho, limitando a escolha ao seu próprio conhecimento. Antunes e Batista (2017, p. 10) apontam que "no processo ensinoaprendizagem cabe aos educadores proporcionar às crianças oportunidades de desenvolver as habilidades motoras fundamentais tornando-as parte importante da prática pedagógica, aperfeiçoando suas habilidades motoras [...]". Os autores afirmam ainda que através da ludicidade o professor "deve contextualizar de forma progressiva a construção das habilidades motoras, através da imagem complexa do seu corpo durante o desenvolvimento das atividades" (ANTUNES e BATISTA, 2017, p. 10)

Nesse contexto a ludicidade deve ser entendida também como recurso pedagógico tendo em vista que passa pela 
concepção de que a função educacional da escola é ensinar e que por isso está tem objetivos educacionais a atingir; a criança, nesse sentido, faz parte da elaboração e orientação rumo a esses objetivos, para chegar à constituição de seu próprio conhecimento.

Nesse sentido, dependendo de como o trabalho pedagógico é desenvolvido a Educação Física enquanto componente escolar a brincadeira pode contribuir de maneira significativa no processo formativo da criança. Para Antunes e Batista (2017, p. 12) "as propostas pedagógicas voltadas para o ensino de Educação Física apresentam-se mais diversificada nos dias atuais, embora a prática pedagógica ainda resista a mudanças". Com isso, pensar na ludicidade como recurso pedagógico para o desenvolvimento infantil, abrange questões sobre as quais os temas trabalhados nas disciplinas acadêmicas e pedagógicas permitem a articulação entre teoria e a prática. Nesse sentido, cabe ao professor conhecer a possibilidade da utilização de diferentes recursos pedagógicos em consonância com a orientação metodológica do seu trabalho.

O espaço da prática pedagógica na escola de educação infantil reflete a importância da noção teórica e prática do professor que atua em sala de aula como forma de sistematizar o conhecimento no processo de ensino-aprendizagem da criança. Nessa perspectiva, é fundamental que o professor estabeleça uma ponte entre a sua própria concepção de brincadeira, com base em suas vivências, e o conhecimento construído a partir de um sólido referencial teórico.

A ponderação sobre a prática lúdica refletida e sistematizada requer a atitude do professor em relação à pesquisa. Assim, ao pesquisar o professor perceberá que durante o processo de ensino-aprendizagem os alunos precisam adquirir conhecimentos significativos para a sua formação. E assim, na construção do saber com base no lúdico a criança enquanto participa da brincadeira, consegue elaborar metas, percebendo e explorando diferentes estímulos, e ao observar todo esse processo o professor pode antecipar alguns resultados, levantando diferentes hipóteses, formulando assim novas estratégias para a sua prática.

Diante disso, ressalta-se a necessidade de fomentar o estudo sobre a ludicidade, em especial a brincadeira, conhecendo suas classificações, identificando se uma brincadeira é ou não adequada a um determinado grupo, analisando a validade desse recurso para que seja utilizado além da recreação e do lazer. 
Acrescenta-se ainda, que as abordagens teóricas que serviram de aporte para a produção da presente categoria apontam que a ludicidade influência de forma direta na aprendizagem das crianças, possuindo assim, um papel fundamental no desenvolvimento físico-motor da criança, principalmente na atualidade, em que o tempo para brincar torna-se comprometido pelas atividades sedentárias a que a criança se vê submetida.

Também a atuação crítica da criança na sociedade, como sujeito da história, pode ser resultado da ação pedagógica por meio do lúdico, pois para a criança o espaço é o corpo vivido, descoberto e conquistado com suas próprias vivências, sendo estas a referência básica para que a brincadeira educativa pode levar o aluno à reflexão acerca de problemas sociopolíticos atuais, como ecologia, papeis sexuais, saúde, relações sociais, preconceitos sociais e raciais, discriminação contra portadores de necessidades especiais, distribuição de solo urbano, de renda etc. Isso possibilita a esse aluno o entendimento da realidade social, levando-o a interpretá-la e a explicá-la tomando por base seus interesses de classe social. Cabe à escola promover a apreensão da prática social, com base na qual os conteúdos podem ser definidos.

Nesse contexto, a brincadeira utilizada como recurso pedagógico, não é elemento que traz um saber pronto e acabado; ao contrário, esse saber precisa ser ativado pelo aluno. Assim, a brincadeira na ação pedagógica é um objeto dinâmico e que se modifica a partir das interações dos alunos.

Quando o professor tem clara a noção de que não é suficiente dar as crianças o direito de brincar, este promove também o incentivo à brincadeira, a identificação do que as leva a brincar e a reflexão sobre todo o processo do jogo. A aplicação de brincadeiras em diferentes situações educacionais é um meio para estimular, analisar e avaliar aprendizagem especificas dos alunos.

Com efeito, durante a prática pedagógica da brincadeira o professor pode perceber na criança as relações de envolvimento, autonomia e criticidade, a argumentação, o raciocínio, a memória e a linguagem. Além disso, a brincadeira envolve motivação, interesse e satisfação, ativando aspectos referentes às emoções e à afetividade, componentes importantes no processo de construção do conhecimento.

Se faz necessário ressaltar que é imprescindível repensar a formação dos educadores em educação infantil e nos anos iniciais do ensino fundamental, trazendo para os currículos de graduação a formação lúdica, para que esses profissionais atuem com conhecimento e domínio das teorias 
sobre os diversos tipos de brincadeiras, sua origem e importância pedagógica no contexto escolar, ampliando, assim, a ação educativa na sala de aula.

É indispensável que o professor possa conhecer a realidade, seu grupo de crianças, seus interesses e necessidades, comportamentos, conflitos e dificuldades e que, paralelamente, constitua um meio de estimular o desenvolvimento cognitivo,

\section{A Educação da Criança Indígena}

O direito à educação está garantido no rol dos direitos sociais elencados pela Constituição Federal (Brasil, 1988), em seu art. 60: "São direitos sociais a educação, a saúde, a alimentação, o trabalho, a moradia, o transporte, o lazer, a segurança, a previdência social, a proteção à maternidade e à infância, assistência aos desamparados, na forma desta Constituição", assim como em seu art. 205. “A educação, direito de todos e dever do Estado e da família, será promovida e incentivada com a colaboração da sociedade, visando ao pleno desenvolvimento da pessoa, seu preparo para o exercício da cidadania e sua qualificação para o trabalho". Portanto, no social, linguístico e cultural e propiciar aprendizagens especificas

Ao professor, cabe, portanto, pautarse sobre uma concepção de ludicidade que vá além de sua prática, entendendo que ela, em diversos momentos, leva o educando a discutir, refletir e explicar conteúdos, possibilitando uma gama de relações no processo ensino e aprendizagem.

Brasil, a educação torna-se, posteriormente à Carta Magna de 1988, dever do Estado e direito dos seus cidadãos.

Essa inscrição na lei é a primeira garantia para o direito, mas não ocorre de forma linear e mecânica; é fruto de lutas embasadas em uma concepção democrática de sociedade, em prol da igualdade de oportunidades e de condições sociais.

A partir da conquista da Constituição, outras leis foram sancionadas para regulamentar o direito à educação. A Lei $\mathrm{n}^{\circ}$ 9.394, de 20 de dezembro de 1996 (Brasil, 1996), estabeleceu as diretrizes e bases da educação nacional. Assim, a educação no Brasil começou a ser organizada nos seguintes níveis e modalidades de educação e ensino: 
Figura 01: Níveis e Modalidades de Ensino

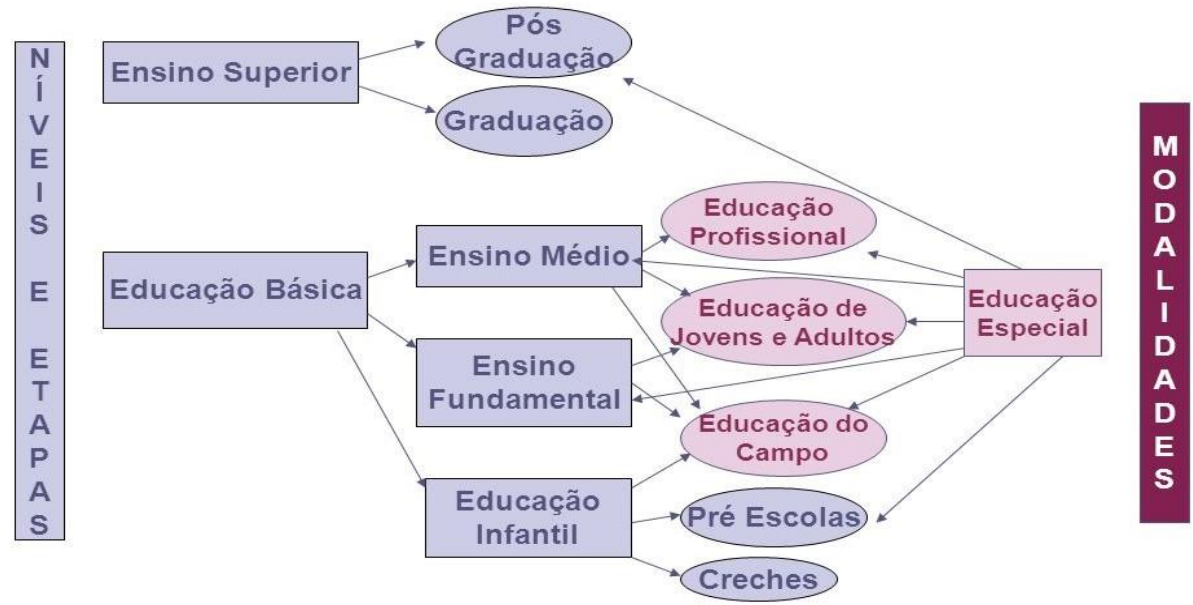

Fonte: Di Pierro (2019).

No que se refere especificamente à educação infantil, historicamente, esta desenvolveu-se lentamente e, até o presente, não tem atendido a toda demanda de crianças na faixa etária entre 0 e 5 anos de idade. A acepção contemporânea da educação infantil difere conforme aqueles que a definem. Pode-se dizer que uma nova concepção de educação infantil é formada a partir do momento em que vários grupos se apropriam de novas ideias.

Para alguns estudiosos da educação infantil há certa concordância em torno da perspectiva que determina a criança como ser adequado para interatuar e produzir cultura no meio em que se encontra. No entanto, para a sociedade formada por pais que levam seus filhos para frequentar as instituições escolares, ainda não há esse consenso, mesmo porque cada um define esse nível de educação com base em suas próprias percepções e vivências, ou seja, com base no contexto histórico e social em que vive (MENDES, 2015)

Assim, inicialmente, de acordo com a história, o atendimento a essa faixa etária não era uma competência atribuída ao setor educacional, mas surgiu associado predominantemente ao setor de assistência social, portanto, com características muito mais assistencialistas do que pedagógicas. Com isso, é possível afirmar que o início da educação infantil brasileira, está ligado à área da assistência social, com intuito por vezes filantrópico, retardou consideravelmente a preocupação com 
políticas educacionais na área (MENDES, 2015).

Somente em meados dos anos 1980 é que se firmou a ponderação a respeito do papel pedagógico das escolas que atendem crianças pequenas, Mendes (2015), afirma que a necessidade de atendimento às crianças por meio de instituições educacionais associa-se ao aumento dos centros urbanos nas cidades, bem como ao processo de inclusão das mães no mercado de trabalho devido ao processo de industrialização. Por um lado, o atendimento a essa necessidade foi uma resposta às pressões da população e, por outro lado, o próprio crescimento da sociedade capitalista (MENDES, 2015).

Acontece que nem sempre se refletiu quanto à atenção para com as crianças, ou seja, nem sempre foram inseridas em primeiro plano as possibilidades de trabalho pedagógico a serem trabalhadas com as crianças - bastava tão somente alguém que as olhasse, lhes trocasse as fraldas, as alimentasse e as colocasse para dormir. Porém, no que se refere à educação era insuficiente (MENDES, 2015).

Devido à expansão da industrialização, à crescente participação da mulher no campo de trabalho e às mudanças no ambiente familiar, houve demanda por instituições destinadas a crianças menores de 07 anos, com isso, houve também uma maior preocupação com o ensino nessas instituições (MENDES, 2015).

No início do século XX, pode-se perceber que se mantém a característica assistencialista das creches e, somente em suas décadas finais, passam a serem adotadas concepções educacionais voltadas para o desenvolvimento e a aprendizagem das crianças (MENDES, 2015).

Algumas mudanças podem ser percebidas a partir da promulgação de leis que contribuíram para a melhoria da Educação Infantil. Dentre tais leis destacam-se a Constituição Federal que aponta que todos tem o direito a educação, o Estatuto da Criança e do Adolescente de 1990 que em seu art. 15 estabelece alguns dos direitos das crianças "A criança e o adolescente têm direito à liberdade, ao respeito e a dignidade como pessoas humanas em processo de desenvolvimento e como sujeitos de direitos civis, humanos e sociais garantidos na Constituição e nas leis", e a Lei de Diretrizes e Bases da Educação Nacional (LDB) 9.394/96 que apresenta a Educação Infantil como parte da educação básica e estabelece artigos que instituem as formas de organização para o atendimento às crianças até os 05 anos de idade e ressaltam o cumprimento do direito à educação (MENDES, 2015).

Assim, com os artigos 29 e 30 da LDB 9.394/96, passa-se a considerar a 
Educação Infantil como primeira etapa da educação básica, além de estabelecer-se sua divisão em creche, responsável pelo atendimento a crianças de 0 a 03 anos, e préescola, destinada a crianças na faixa etária de 04 a 05 anos. Nesse sentido, observamse avanços se comparada essa lei com as leis vigentes anteriormente (MENDES, 2015).

Nesse ponto destaca-se a educação infantil ofertada aos povos indígenas, onde Grando (2014, p. 98) afirma que através de estudos antropológicos sobre a criança indígena brasileira, é possível compreender que "na infância indígena, a educação se dá a partir das formas como cada comunidade pensa e organiza a vida coletiva a fim de garantir o futuro das novas gerações”. Desta forma a oferta da educação para as crianças indígenas "é opcional, cabendo a cada comunidade indígena decidir sobre seu oferecimento" (TROQUEZ, 2016, p. 80).

A autora destaca ainda que "a oferta da educação infantil deve considerar as especificidades e os direitos à diferença e à autodeterminação dos povos indígenas, bem como a participação da comunidade no processo" (TROQUEZ, 2016, p. 80).

Muitos historiadores relatam que o processo de transmissão dos saberes às crianças nas comunidades indígenas é pautado inicialmente pela observação e imitação, assim, nas palavras de Silva (2014, p. 658), a educação infantil indígena é considerada "comunitária", que ocorre "principalmente através da intensa participação das crianças na vida da aldeia, integrada nas atividades cotidianas e rituais de seu grupo, como se toda a ação presente fosse considerada exemplar e modelar".

Silva (2014, p. 664) afirma que a participação da criança é iniciada logo cedo, assim que ela começa a andar, realizando algumas tarefas da casa, assim,

'[...] Quase sempre elas testemunham as atividades realizadas na casa ou no quintal, mantendo proximidade com as pessoas que as executam, mas apenas observando-as. A observação por parte das crianças constitui-se em uma característica muito forte no grupo".

Acerca desse convívio entre os adultos e o aprendizado comunitário Grando (2016, p. 90) afirma que "as crianças têm a liberdade de experimentar as atividades dos adultos e nisso são respeitadas, no entanto a aprendizagem é sempre uma iniciativa da criança, e a correção dessas aprendizagens não é feita de forma incisiva, mas no tempo próprio de cada criança".

Esse tipo de educação é conhecido comumente como educação informal, que ocorre fora das instituições escolares, mais 
precisamente no ambiente familiar e cultural, sem a presença de técnicas pedagógicas.

Entende-se com isso, que sob a perspectiva da educação indígena, a criança aprende conhecendo, vivenciando o cotidiano da aldeia e, mais que isso, seguindo a vida dos mais experientes, imitando, inventando, idealizando, sendo que o clima familiar, formado pelo conjunto de consanguinidade, proporciona a autonomia e liberdade imprescindíveis para essa aprendizagem infantil.

A importância dessa aprendizagem informal fundamenta-se no fato de que a transmissão de regras de comportamento socia, de domínio do mundo material e espiritual, tudo isso era passado através de um ensinamento baseado no dia a dia, variado em suas formas, mas substantivo.

Dessa forma os índios adultos transmitiam às crianças os conhecimentos para que pudessem fazer um vaso de cerâmica, um artefato de pedra ou de madeira, de modo que aprendessem a caçar, pescar, lutar em guerra. Essa educação dos cinco sentidos (olfato, tato, paladar, visão e audição) era dada através do gesto técnico, que consistia na capacidade humana, de por meio de gestos observados e aprendidos de manejar e modificar os objetos.

Para uma criança não índia pode não ser uma tarefa fácil fazer um arco e flecha, uma canoa ou moldar e cozer um vaso de barro, no entanto para uma criança indígena ao observar diariamente essas atividades, tornava-se simples e comum executá-las. Por isso, a observação e imitação era algo importante no processo de aprendizagem entre os índios, tendo em vista que não havia cursos nem cartilhas explicativas, mas sim a transmissão da gestualidade que permitia a que a vida diária se perpetuasse.

Além da gestualidade a oralidade também se destaca como forma de transmissão de conhecimento na educação infantil indígena, onde a palavra dos índios mais velhos se faz presente na vida cotidiana, e com isso as crianças aprendiam sobre os costumes indígenas, como afirmam Bergamaschi e Menezes (2016, p. 751), "não apenas na fala, mas na escuta respeitosa e atenta: escutar e entoar os cantos e se dispor ao ensinamento que é oferecido pela palavra são marcas importantes nos processos próprios de aprendizagem".

Embora a educação informal ainda se faça presente em muitas comunidades indígenas, o reconhecimento de que esses povos são portadores de especificidades políticas e culturais e que tem o direito de viver conforme suas próprias referencias e decidir sobre seu futuro trouxe consequências diretas à política educacional. Desse modo, a criação da categoria 'escola indígena' dentro dos sistemas de ensino, consistiu num grande 
avanço em comparação aos padrões anteriores, embora não contemple totalmente as expectativas dos povos indígenas.

Essa nova realidade da criança indígena inserida em um sistema de ensino, ao vivenciar outras experiências no sistema de ensino embora se apresente como uma perspectiva promissora, aponta certo conflito existente, tendo em vista que "as crianças indígenas recebem desde o nascimento, o ensinamento dos mais velhos no sentido da preparação para uma vida indígena futura, o que se aprende na escola pode estar sendo conflitante com a que lhes é culturalmente oferecido" (JANKAUSKAS et al, 2015, p. 02).

Entretanto, estes conflitos culturais que as crianças indígenas vivenciam possibilita uma condicionalidade característica e cultural, nesse sentido, a transformação identitária determinada pelos conflitos, não é compreendida pela criança indígena, que ao ser inserida em uma instituição escolar tende a negar e/ou esquecer sua cultura, perdendo parte da referência segura que a faz relacionar-se socialmente entre a cultura indígena e não indígena.

Assim, considerando que as crianças indígenas aprendem brincando e atuando juntamente com a comunidade em que está inserida, apreendendo os saberes dos índios mais velhos, pode-se afirmar que a educação escolar infantil indígena "precisa ser pensada a partir da identidade sociocultural de cada povo, constituindo-se a continuidade da educação tradicional oferecida na e pela família, e, nesse aspecto, é que reside o específico e diferenciado na educação intercultural" (IVES-FELIX e NAKAYAMA, 2018, p. 43).

Como se sabe a educação intercultural é compreendida como uma prática social que se relaciona intensamente com as dinâmicas distintas da comunidade escolar. Relacionando tal concepção de educação intercultural com a realidade da educação indígena, percebe-se que "no campo da educação escolar indígena, diferentes interpretações acerca da interculturalidade e/ou diálogo intercultural enquanto proposta e projeto educativo têm causado muitas controvérsias" (Nascimento, Quadros e Fialho, 2016, p. 196). Uma vez que ao refletir sobre a inserção da interculturalidade no dia a dia das escolas indígena supõe-se que o modelo de educação assimilacionista será trocado por um modelo de educação voltado especificamente para os povos indígenas, porém se percebe que o modelo de educação assimilacionista predomina os currículos de muitas indígenas.

Nascimento (2017, p. 385) afirma que é possível perceber no currículo das escolas indígenas "um conjunto de 
demandas que aludem ao problema do reconhecimento na esfera pública em face das situações de preconceito e reclamam o direito à diferença, negado no modelo já referido da educação escolar para os indios". Assim, o questionamento a respeito de um currículo específico para as escolas indígenas se faz necessário, no contexto da necessidade de atendimento à educação diferenciada.

Nesse sentido Nascimento (2017, p. 385) afirma que, "a percepção dos indígenas sobre o papel da escola diferenciada está ligada às disputas simbólicas - e também materiais, uma vez que são reivindicados recursos específicos que constituem as políticas de educação escolar indígena".

Dessa forma entende-se que é necessário que as crianças indígenas se apropriem dos conhecimentos exteriores, porém, é fundamental defender a ideia da inserção de conhecimentos indígenas no currículo escolar, considerando que esses podem sem escolarizados, sendo apropriados para a educação escolar indígena. Com isso ao se pensar em um currículo específico na Educação Escolar Indígena é preciso falar de sua flexibilidade, no sentido de que esteja sempre aberto, e adequado à realidade de cada comunidade.

Existem políticas públicas que garantem a construção dessa especificidade curricular para as escolas indígenas, conforme se observa no artigo 78 da LDB 9.394/96, onde se estabelece que se deve “desenvolver currículos e programas específicos, neles incluindo os conteúdos culturais correspondentes às respectivas comunidades" (BRASIL, 2018, p. 34).

É possível mencionar ainda as Diretrizes Curriculares Nacionais para Educação Escolar Indígena, onde consta em seu art. $8^{\circ}$, que as escolas que ofertam a educação às crianças indígenas devem " $\$ 3^{\circ}$ III - considerar as práticas de educar e de cuidar de cada comunidade indígena como parte fundamental da educação escolar das crianças de acordo com seus espaços e tempos socioculturais" (BRASIL, 2012, p. 4). O mesmo documento acrescenta ainda, que tais escolas precisam "IV - elaborar materiais didáticos específicos e de apoio pedagógico para a Educação Infantil, garantindo a incorporação de aspectos socioculturais indígenas significativos e contextualizados para a comunidade indígena de pertencimento da criança" (BRASIL, 2012, p. 4).

Nesse contexto, a inserção da criança indígena no sistema de ensino regularizado permite iniciar um novo ciclo de aprendizagem onde ela será exposta à diversas ferramentas de sistematização de conhecimentos, o que possibilita com isso, compreender e dominar os saberes 
indígenas associando-os com os saberes não indígenas.

\section{A Ludicidade na Educação Infantil Indígena}

A Educação Infantil é uma etapa fundamental da Educação Básica, onde a construção do espaço e da identidade da criança é feita à medida que são efetivadas as políticas de atendimento. Nesse período a utilização da ludicidade durante as aulas pode gerar oportunidades de aprendizagem, incluindo $\mathrm{o}$ respeito à diversidade e a formação da identidade. Assim, a escola pode proporcionar um ambiente lúdico para a aprendizagem significativa, embora muitas vezes não é nesse cenário que a aprendizagem ocorre.

De acordo com Teixeira (2018, p. 141) "o pano de fundo que se descortina em muitas realidades educacionais brasileiras é a intercorrência de uma aprendizagem mecânica, baseada na memorização e em metodologias que não se contextualizam com atividades práticas do dia a dia e que não refletem a realidade da infância". Assim, para que a aprendizagem escolar seja significativa é necessário que ocorra uma interação entre os conhecimentos prévios e os novos conhecimentos, com a utilização de um modelo de aprendizagem menos engessado, mais dinâmico, relacionando as práticas cotidianas e com foco na resolução de problemas. Nesse sentido, os aspectos lúdicos, ganham um significado especial.

A atividade lúdica em si, no entanto, nem sempre gera aprendizagem. Ela precisa de intervenção do educador, de forma planejada e intencional. Um educador comprometido com a aprendizagem dos alunos não deve focar em seu trabalho, somente a memorização; ele precisa vivenciar uma prática que tenha significado para o aluno. As brincadeiras e os jogos comumente fazem parte da rotina dos alunos e, aliados aos demais aspectos lúdicos, como a literatura, os desenhos, a música, a dramatização e a arte como um todo, promovem resultados mais produtivos para a aprendizagem.

Segundo Mota e Ramires (2018, p. 2), "a realidade educacional das instituições de educação infantil comporta a necessidade de uma prática pedagógica lúdica que venha respeitar o processo de aprendizagem das crianças indígenas e não indígenas". No que se refere ao aprendizado das crianças indígenas pode-se afirmar que estas aprendem imitando os costumes do cotidiano na comunidade, conforme aponta Figueiredo e Azevedo (2014, p. 139), “o aprendizado da criança, nas etnias indígenas, começa na imitação dos habitus, 
brincadeiras que imitam as tarefas femininas".

Nesta perspectiva a ludicidade permite à criança indígena a imitação de diversos papeis, usualmente do seu dia a dia, ato que promove a expressão de sentimentos e relações que estabelece, com as pessoas do meio. A imitação também é um elemento que garante à criança indígena experimentar atitudes que permite desenvolver habilidades e valores importantes, "como, por exemplo, a preparação de alimentos - o biju; as crianças desenvolvem objetos, como as primeiras cestas de fibras para as meninas e a confecção dos pequenos arcos e flechas para os meninos, fazendo da própria natureza física seu momento de experiências" (FIGUEIREDO e AZEVEDO, 2014, p. 139). Dessa forma, quando brinca de faz de conta, imitando as tarefas dos índios adultos, a criança age e enfrenta desafios, organiza o pensamento e elabora suas regras, o que facilita a transposição do mundo adulto para o seu universo.

De acordo com o Referencial Curricular Nacional para Educação Infantil "a brincadeira favorece a autoestima das crianças, auxiliando-as a superar progressivamente suas aquisições de forma criativa. Brincar contribui, assim para a interiorização de determinados modelos de adultos, no âmbito de grupos sociais diversos" (BRASIL, 1998, p. 27). É possível entender com isso, que a brincadeira propicia o trabalho com diferentes linguagens, o que facilita a transposição e a representação de conceitos elaborados pelo adulto para as crianças.

A brincadeira permite ainda a potencialização da aprendizagem e do desenvolvimento da criança através da interação com outras crianças e com os adultos. Nesse sentido, segundo a Base Nacional Comum Curricular (BNCC), “interação durante o brincar caracteriza o cotidiano da infância, trazendo consigo muitas aprendizagens e potenciais para o desenvolvimento integral das crianças" (BRASIL, 2017, p. 37), e acrescenta ainda que, "ao observar as interações e a brincadeira entre as crianças e delas com os adultos, é possível identificar, por exemplo, a expressão dos afetos, a mediação das frustrações, a resolução de conflitos e a regulação das emoções" (BRASIL, 2017, p. 37).

A fim de facilitar esse processo a BNCC estabeleceu seis direitos de aprendizagem e desenvolvimento que “asseguram, na Educação Infantil, as condições para que as crianças aprendam em situações nas quais possam desempenhar um papel ativo em ambientes que as convidem a vivenciar desafios e a 
sentirem-se provocadas a resolvê-los, nas quais possam construir significados sobre si, os outros e o mundo social e natural"
(BRASIL, 2017, p. 37), conforme se pode observar no quadro abaixo:

Quadro 02: Direitos de Aprendizagem e Desenvolvimento na Educação Infantil

Conviver com outras crianças e adultos, em pequenos e grandes grupos, utilizando diferentes linguagens, ampliando o conhecimento de si e do outro, o respeito em relação à cultura e às diferenças entre as pessoas.

Brincar cotidianamente de diversas formas, em diferentes espaços e tempos, com diferentes parceiros (crianças e adultos), ampliando e diversificando seu acesso a produções culturais, seus conhecimentos, sua imaginação, sua criatividade, suas experiências emocionais, corporais, sensoriais, expressivas, cognitivas, sociais e relacionais.

Participar ativamente, com adultos e outras crianças, tanto do planejamento da gestão da escola e das atividades propostas pelo educador quanto da realização das atividades da vida cotidiana, tais como a escolha das brincadeiras, dos materiais e dos ambientes, desenvolvendo diferentes linguagens e elaborando conhecimentos, decidindo e se posicionando.

Explorar movimentos, gestos, sons, formas, texturas, cores, palavras, emoções, transformações, relacionamentos, histórias, objetos, elementos da natureza, na escola e fora dela, ampliando seus saberes sobre a cultura, em suas diversas modalidades: as artes, a escrita, a ciência e a tecnologia.

Expressar, como sujeito dialógico, criativo e sensível, suas necessidades, emoções, sentimentos, dúvidas, hipóteses, descobertas, opiniões, questionamentos, por meio de diferentes linguagens.

Conhecer-se e construir sua identidade pessoal, social e cultural, constituindo uma imagem positiva de si e de seus grupos de pertencimento, nas diversas experiências de cuidados, interações, brincadeiras e linguagens vivenciadas na instituição escolar e em seu contexto familiar e comunitário. Fonte: Brasil (2017, p. 38).

\section{É possível perceber como a BNCC} ressalta o direito de brincar da criança e desse modo, entende-se que para considerar e executar os direitos da aprendizagem e desenvolvimento apontados pela BNCC, se faz necessário tê-los sempre em mente garantindo assim que os conhecimentos propostos estejam em conformidade com os aspectos básicos.

Nesse sentido, em relação ao conhecimento sobre a brincadeira na educação infantil indígena, o educador que optar em utilizar as brincadeiras como recurso pedagógico pode partir da reflexão sobre como o lúdico está presente no cotidiano infantil indígena. Assim, é preciso que se delimitem esforços para garantir à criança indígena um espaço que possibilite a ação lúdica, ou seja, um ambiente no qual ela tenha a oportunidade de escolher os jogos, os materiais e o modo de explorar e criar suas brincadeiras.

Nesse período em que a criança é inserida no ambiente escolar, sabe-se que do mesmo modo que há a interação com os outros, e a linguagem oral, há também um grande desenvolvimento físico-motor, que possibilita uma mudança significativa nas relações com o mundo. Desse modo, a criança vai desenvolvendo movimentos que 
lhe permitem uma atuação mais autônoma no seu meio, tanto em relação às possibilidades de deslocamento, quanto na perspectiva do autocuidado.

Entende-se que o desenvolvimento dos movimentos é muito significativo para a criança indígena, tendo em vista que "as práticas corporais, nas sociedades indígenas, constituem bens culturais que refletem suas tradições e comportamentos" (TENÓRIO e SILVA, 2014, p. 89). Assim, a corporalidade é considerada "como o processo de construção e linguagem expressiva [...]" (FIGUEIREDO e AZEVEDO, 2014, p. 138).

Ao trabalhar a corporeidade na educação infantil, permite-se que a criança se aproprie dos gestos e do repertório de atividades culturais relacionados ao movimento, que lhe permitem a realização de ações e procedimentos, bem como compreender e expressar ideias, sentimentos e desejos. Essas apropriações ocorrem nas relações sociais e afetivas com os sujeitos da cultura e nas relações que ela estabelece com a natureza, que ela estabelece com a natureza, constituindo-a como sujeito nesse mundo social e natural.

Tendo em vista que essas são aquisições das crianças, principalmente na faixa etária de 0 a 6 anos, evidencia-se a importância do trabalho desenvolvido nas instituições de Educação Infantil, no sentido de favorecer às crianças a construção de sua corporeidade.

Uma das maneiras mais significativas de favorecer esse processo na educação infantil indígena, é possibilitar que as crianças vivenciem jogos e brincadeiras, principalmente nos espaços externos da escola, onde possam explorar as possibilidades do seu próprio corpo, tocar o corpo dos colegas, expandir seus movimentos, correndo, pulando, subindo, rolando, balançando, escorregando, empurrando pneus ou outros objetos, brincando na água etc.

Mesmo nos espaços internos, em vez de manter as crianças por longo tempo nos berços ou sentadas nas mesinhas, o professor pode organizar espaços e materiais que permitam a vivência do corpo no espaço, como tuneis, rampas, obstáculos, colchões, almofadas, caixas grandes de papelão, ou mesmo pode transformar as mesinhas e cadeiras de sala em ônibus, cavernas, cabanas, trampolins para mergulhar nos colchões que viram 'rios, piscinas ou praias'.

Segundo Barros et al. (2014, p. 40) como "o brincar, é uma atividade dominante no modo de vida das crianças na aldeia, é preciso ampliar o seu significado na escola indígena, a partir da reflexão e da interação dos professores indígenas ou não, tornando possível o desenvolvimento de 
ações que levam à significação e a ressignificação do fazer pedagógico a partir do brincar". Com isso, é importante ressaltar que as experiências vivenciadas pelas crianças indígenas na escola precisam favorecer, ao mesmo tempo, o desenvolvimento da corporeidade, da capacidade de compartilhar significados, sentimentos, e de imaginar, na medida em que acabam por se constituir em jogos dramáticos, danças e imitações que exploram a gestualidade e a linguagem cênica.

Essas propostas vão no sentido contrário daquelas que artificializam e padronizam as possibilidades de expressão corporal e imaginativa das crianças, por meio de apresentações de 'teatrinhos' e 'dancinhas' que são exaustivamente treinados, ensaiados, com o intuito único de as crianças se mostrarem aos pais e a outros adultos. Elas se contrapõem também àquelas propostas escolarizantes que, em vez de trazer a compreensão da corporeidade se realiza na interação com o outro em vivências significativas do corpo no espaço, refletem a concepção de que as crianças aprendem por meio da repetição e do treinamento.

É fundamental que em todas as suas ações o professor esteja atento, na sua prática pedagógica, à construção da autoestima pelas crianças e ao desenvolvimento de atitudes de respeito, confiança, cooperação e tolerância no grupo. Nesse contexto, a contação de histórias, além de estimular a imaginação das crianças, em um clima de alegria e descontração, permite que as atitudes anteriormente mencionadas sejam desenvolvidas. Para Figueiredo e Azevedo (2014, p. 140), “ouvir e contar histórias são uma prática que, desde muito cedo, através de narrativas, transmitem o imaginário povoado de figuras que ligam o universo cultural do índio a seus entes míticos. Assim, perpetuam a memória e a cultura de seu povo no inconsciente das crianças. Elas aprendem a reconhecer a si e aos outros", e assim outros objetivos podem ser alcançados tais como educar, instruir desenvolver a capacidade intelectual delas.

Dessa forma, as histórias podem ser usadas tanto como ponto de partida para ensinar determinados conteúdos programáticos quanto como instrumento que facilita a compreensão do comportamento das crianças no campo pessoal.

É sabido que contar histórias é uma das mais antigas artes encontradas nas mais diversas nações, sendo que historicamente, a função social do conto representou diferentes papéis de acordo com a cultura e as características destas sociedades. Tal arte está ligada à essência do ser humano tanto 
que as narrativas tradicionais expressam, em imagens, as verdades mais profundas da vida, e por isso, se tornam eternas.

O contador de histórias tinha grande importância social e cultural no passado, sendo considerado uma espécie de depositário da experiência, do conhecimento e da sabedoria de sua época. Posteriormente, essa arte adquiriu status de rito familiar que, possibilitava a criação de clima mais íntimo, favorável à relação entre as gerações. Diante disso pode-se perceber, portanto, que o processo da contação de história, por ser uma arte antiga, associa-se com a história da nossa própria cultura, a cultura humana. Figueiredo e Azevedo (2014, p. 140) afirmam que "os contadores de histórias passam para os jovens muito mais que narrativas, eles sedimentam alicerces para novas posturas e isso é educar".

Com isso, a história contada pode ser fundamentada tanto na formação educativa quanto na formação cultural da criança, tendo em vista que o conto infantil supre a necessidade da curiosidade e descoberta que a criança possui.

Embora o atrativo inicial dos contos seja o de entreter e encantar, seu valor principal fundamenta-se no poder de ajudar as crianças a lidar com os conflitos internos, que se apresentam no processo de crescimento. Em consequência desses aspectos, os contos também oferecem às crianças um palco, no qual elas podem representar seus conflitos interiores.

Diante dessa constatação torna-se fácil perceber a importância das histórias contadas no cotidiano escolar. Entretanto, não basta tão somente ler uma história em sala de aula. Além de uma boa história, que deve ser escolhida de acordo com a faixa etária da criança, e do próprio desempenho do contador, ainda há de se utilizar de materiais ilustrativos para despertar o interesse infantil.

Assim ao ler uma história é preciso chamar a atenção da criança usando diferentes recursos, mostrando a ela que ler não é apenas um ato que se transforma em hábito, mas sim uma importante ferramenta na formação de pessoa, onde envolve a cultura e a forma de compreender e entender o mundo.

Considerando que os contos podem ser utilizados no cotidiano escolar de forma relacionada à concepção de infância que permeia o discurso pedagógico percebe-se a necessidade de resgatar o prazer da leitura, bem como, da contação de histórias, estimulando assim a inteligência, discutindo valores, permitindo a exploração da criatividade, imaginação e da socialização.

Nesse contexto, é importante que o educador reflita sobre como a utilização da contação de história, ainda que considerada 
como brincadeira pode contribuir para o desenvolvimento do potencial criativo dos alunos, apresentando desafios de valor sociocultural em uma perspectiva mais dinâmica. Mota e Ramires (2018, p. 8) afirmam que, "faz-se necessário que o professor compreenda a criança indígena como um sujeito produtor de cultura, como um ser social pleno e diferenciado inserido

\section{CONCLUSÃO}

A ludicidade tem um papel fundamental na Educação Infantil, tendo em vista que ela possibilita e proporciona às crianças diversas experiências através de contextos nas quais elas possam criar, inventar, se descobrir, elaborar conceitos e ideias sobre o movimento e suas ações. Essa ferramenta quando utilizada nas aulas da Educação Infantil Indígena pode ser considerada como um recurso pedagógico promissor.

Nesse contexto, considerando que a brincadeira é um instrumento pedagógico muito significativo e de grande valor social, o presente trabalho foi realizado através de uma revisão sistemática integrativa, objetivando analisar a concepção da ludicidade a fim de compreender os caminhos construídos para essa prática na educação infantil indígena.

Com esta pesquisa evidenciou-se através das teorias dos autores estudados em um contexto sociocultural com suas peculiaridades", por isso, quando uma criança indígena começa frequentar uma instituição escolar é importante que o professor reconheça e valorize os conhecimentos prévios que ela obteve na comunidade indígena, associando-os aos novos conhecimentos, através de uma prática lúdica e afetiva.

que o ato de jogar e brincar além de estimular a imaginação das crianças indígenas atinge outros objetivos como permitir que as crianças possam experimentar vários aspectos da vida, encarando assim emoções conflitantes quando representadas à vida real. A ludicidade apresenta-se, portanto, como um recurso pedagógico que oportuniza conhecer a realidade dos seus alunos, seus interesses e necessidades, comportamentos, conflitos e dificuldades, bem como educar, instruir e desenvolver a capacidade intelectual delas.

O breve histórico apresentado apontou como a educação tem evoluído ao longo do tempo, onde se percebeu a busca de uma educação de qualidade para as crianças indígenas. A ludicidade passa, então, a adquirir um sentido mais abrangente, sendo compreendida como um recurso pedagógico que se presta ao diagnóstico do processo de aprendizagem infantil como uma maneira do professor 
perceber o aluno em uma perspectiva cognitiva, afetiva, psicomotora e social.

Nesse contexto o professor surge como peça fundamental, agindo como mediador entre a criança e o conhecimento, tendo em vista que não basta a criança jogar e brincar se não souber agir sobre os jogos e as brincadeiras.

Fundamenta-se, portanto, a importância da utilização da ludicidade como recurso pedagógico na educação

\section{REFERÊNCIAS}

ALMEIDA, J. A. et al. Infância e educação infantil indígena: um estudo da criança Apinajé. Facit Business and Tecnology Journal. 2 (1), p. 103-118, 2017.

ANDRIOLLI, L. R.; GAUSTINO, R. C. Vivências de crianças indígenas Kaingang na cidade: elementos para a aprendizagem e o desenvolvimento. Revista Humanidades e Inovação. v. 6, n. 15, 2019.

ANTUNES, P.; BATISTA, F. M. R. Brincar de aprender; a ludicidade como recurso didático na educação infantil. R. Eletr: Cient. Inov. Tecnol., Medianeira, v. 8, n. 17, 2017.

BARROS, J. C. et al. O brincar das crianças Sataré-Mawé e suas relações interculturais com a educação escolar indígena. RPCD, Universidade Federal do Amazonas, Manaus, 14 (1): 26-48, 2014.

BERGAMASCHI, M. A.; MENEZES, A. L. T. Crianças indígenas, educação, escola e interculturalidade. Revista ecurriculum, v. 14, n. 2, abril./jul, p. 741764, 2016. infantil indígena, uma vez que ela supre a necessidade da curiosidade e descoberta que a criança possui. Considerando que esta utilização, quando trabalhada de forma adequada, pode ser fundamentada tanto na formação educativa, quanto na formação cultural da criança indígena, entende-se que esta prática se torna, indiscutivelmente necessária no processo ensinoaprendizagem.

\section{BRASIL. Base Nacional Comum}

Curricular: Educação Infantil e Ensino Fundamental. Brasília: MEC/Secretaria de Educação Básica, 2017.

\section{Diretrizes Curriculares}

Nacionais para a Educação Infantil. Brasília, DF: Ministério da Educação, 2009.

LDB: Lei de diretrizes e bases da educação nacional. - 2. ed. - Brasília: Senado Federal, Coordenação de Edições Técnicas, 2018.

Ministério da Educação e do

Desporto. Referencial Curricular Nacional para Educação Infantil. Brasília: DF: MEC, 1998. Vol. 1.

CONTI, K. C. et al. Criação de jogos no contexto indígena: o cabo de guerra numérico. Polyphonía. v. 28/2, jul./dez. 2017.

Uso de jogos matemáticos como proposta pedagógica num contexto de formação intercultural para professores indígenas. Cadernos Cenpec. São Paulo, v. 8, n. 1, p. 180-206, jan./jul. 2018.

DELLE-PIAGGE, A. C. M. et al. Reflexões acerca da boneca indígena: educação escolar, diversidades e infâncias. 


\section{Revista Eletrônica da Educação,}

Releduc, v. 2, n. 2, ago, 2019.

DI PIERRO, M. C. A organização do sistema de ensino brasileiro. Disponível em: <

https://slideplayer.com.br/slide/293758/>

Acesso em: 20 de novembro de 2019.

DOMINGUES-LOPES, R. C. et al. O lúdico em questão: brinquedos e brincadeiras indígenas. Desidades, v. 6 , Rio de Janeiro, mar. 2015.

FAUSTINO, K. C.; MOTA, L. T. Crianças indígenas: o papel dos jogos, das

brincadeiras e da imitação na aprendizagem e no desenvolvimento. Acta Scientiarum Education, Maringá, v. 38, n. 4, p. 395-404, oct./dec. 2016.

FIGUEIREDO, L. M. S.; AZEVEDO, L. F. Jogos e brincadeiras indígenas em Mato Grosso. Unopar Cient. Ciênc. Human. Educ., Londrina, v. 15, n. 2, p. 137-141, jun, 2014.

GODOY, M.; FERREIRA, E. O universo cultural da criança Guarani Mbya e a presença dos centros educacionais e culturais indígenas, Cecis, nas aldeias de Saõ Paulo. Cadernos CERU, 25 (1), P. 101-120, 2014.

GRANDO, B. S. Infância, brincadeiras e brinquedos em comunidades indígenas brasileiras. Revista Aleph. Ano XI, n. 22, dezembro, 2014.

Educação da criança indígena e educação infantil em Mato Grosso: uma questão para o debate. Tellus, Campo Grande, MS, ano 16, n. 31, jul./dez. 2016. IVES-FELIX, N. O.; NAKAYAMA, L. A danada da escola está lá: educação infantil vivenciada pelas crianças indígenas Tentehar maranhenses, a partir das falas dos seus interlocutores. Tellus, Campo Grande, MS, ano 18, N. 36, P. 39-66, maio/ago. 2018.
JANKAUSKAS, R. M. B. et al. A educação infantil na escola indígena na comunidade de Umariaçu II. VII FIPED Fórum Internacional de Pedagogia, Parintins, AM. v. 1, 2015.

LUCKESI, C. Ludicidade e formação do educador. Revista entre ideias, Salvador, v. 3, n. 2, p. 13-23, jul./dez. 2014.

MARTINS, R. et al. O resgate das memorias do jogo e brincadeiras de uma comunidade indígena. Athlos - Revista Internacional de Ciencias Socialies de $\mathrm{La}$ Actividad Física, el Juego y el Deporte. v. XVI - ano VIII, Enero, 2019.

MELO, A.; RIBEIRO, D.

Interculturalidade e educação infantil: reflexões sobre diferenças culturais na infância. Conjectura: Filos, Educ., Caxias do Sul, RTS, Ahead of Print, v. 24, e019039, 2019.

MELO, J. C. A função do lúdico na transição da educação infantil para o primeiro ano do ensino fundamental. Revista Humanidades e Inovação. v. 6, n. 15, 2019.

MENDES, S. L. Tecendo a história das instituições do Brasil infantil. SABERES, Natal-RN, v. 1, n. 11, p. 94-100, Fev. 2015.

MOTA, L. K. L.; RAMIRES, C. R. Educação infantil indígena e a ludicidade: a percepção de agentes escolares na aprendizagem da criança. III Seminário Internacional em Sociedade e Cultura no Pan-Amazônica. Universidade Federal do Amazonas-UFAM, Manaus, 21 a 23 de novembro, 2018.

NASCIMENTO, R. G. Escola como local das culturas: o que dizem os índios sobre escola e currículo. Revista Educ. Public. Cuiabá, v. 26, n. 62/1, p. 373-389, maio/ago. 2017. 
NASCIMENTO, R. N. F.; QUADROS, M. T.; FIALHO, V. Interculturalidade enquanto prática na educação escolar indígena. Revista Antropológicas, 27 (1): 187-217, 2016.

PINHO, V. A.; TOMAZZETTI, C. M. Infâncias, saberes e diversidade: um diálogo com a educação infantil. Revista

Educ. Públ., Cuiabá, v. 26, n. 62/2, p. 617638, maio/ago, 2017.

PORTO, S. G. S. Ludicidade: um caminho para ressignificar a prática pedagógica e o desenvolvimento da criança na educação infantil. Revista Cientifica Multidisciplinar núcleo do conhecimento. Ano 03, ed. 08, v. 12, p. 72-83, agosto de 2018.

RAMIRES, C. R.; MOTA, L. K. L. Educação infantil indígena e a formação de professores: aspectos legais e a importância da qualidade educacional préescolar na voz docente. III Seminário Internacional em Sociedade e Cultura no Pan-Amazônica. Universidade Federal do Amazonas-UFAM, Manaus, 21 a 23 de novembro, 2018.

RODRIGUES, W. Relacionando ludicidade e matemática na infância indígena. Revista Didática Sistêmica. V. 20, n. 2, p. 120-130, 2018.
SANTANA, F. M. N. et al. Ludicidade e o contexto cultural diversificado: contribuições e desafios no processo ensinar e aprender. Revista Diálogos Interdisciplinares - GEPFIP. Aquidauana, v. 1, n. 3, p. 37-49, dez. 2016.

SILVA, M. et al. Brinquedos e brincadeiras indígenas Kaingangs: transfiguração entre gerações. Revista Mackenzie de Educação Física e Esporte. v. 14, n. 2, p. 54-61, 2015.

SILVA, R. C. Participação e aprendizagem na educação da criança indígena. Revista brasileira de Educação. v. 19, n. 58, jul./set. 2014.

TEIXEIRA, K. L. O universo lúdico no contexto pedagógico. Curitiba:

Intersaberes, 2018. (Série Panoramas da Psicopedagogia).

TENÓRIO, J. G.; SILVA, C. L. As práticas corporais indígenas como conteúdo da educação física escolar. Revista Teoria e Prática da Educação. v. 17, n. 1, p. 81-91, janeiro/abril, 2014.

TROQUEZ, M. C. C. Educação infantil indígena na legislação e na produção do conhecimento. Horizontes - Revista de Educação. Dourados, MS, v. 4, n. 7, janeiro a junho, 2016. 


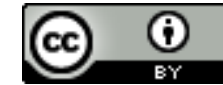

Esta obra está sob o direito de Licença Creative Commons Atribuição 4.0 Internacional.

\section{ANÁLISE DOS SISTEMAS DE ESGOTAMENTO SANITÁRIO ÚNICO E SEPARADOR}

Flávio Júnior Bezerra ${ }^{1}$

Gabryell Henrique Amancio da Silva ${ }^{2}$

Igor Bruno do Nascimento Santos ${ }^{3}$

Ivis Kally Pereira Patriota ${ }^{4}$

Letícia Karen Pereira Martins ${ }^{5}$

Eduardo Cabral da Silva ${ }^{6}$

\section{RESUMO}

Esgotamento sanitário é o conjunto de medidas que visam modificar e prevenir problemas relacionados as condições do meio ambiente. Basicamente está relacionado ao abastecimento de água, o manejo de água pluvial, a coleta e tratamento de esgoto. Em épocas chuvosas existe grande probabilidade de sobrecarregamento das redes, ocasionando transtorno à população e danos orçamentários aos municípios. Quais seriam as melhores estruturas do esgotamento sanitário para evitar problemas ocasionados por enchentes? O presente trabalho tem como objetivo apresentar os pontos positivos e negativos de uma rede de esgotamento sanitário com separação das águas pluviais e efluentes por meio de discussões. $\mathrm{O}$ artigo trata-se de uma revisão bibliográfica do tipo sistemática integrativa, onde arquivos foram pesquisados no Periódicos CAPES, utilizando os descritores: efluentes, esgotamento sanitário, sistema e estação de tratamento, empregando escolha dos critérios de inclusão e exclusão. Identificando estudos pré-selecionados e selecionados através da leitura dos agentes indexadores das publicações. Por meio das discussões e os resultados obtidos, a conclusão enquanto pode alcançar é que o esgotamento sanitário separador é o ideal no sistema de esgotamento sanitário.

Descritores: Efluentes. Pluviais. Rede. Tratamento. Ambiente.

\footnotetext{
1 flavio.junior@grupomoura.com

2 henriquegabryell08@hotmail.com

3 igor.ns996@gmail.com

4. ivis.patriota@gmail.com

5. leticia_karen2011@hotmail.com

${ }^{6}$ eduardo.csilva@professores.unifavip.edu.br
} 


\section{INTRODUÇÃO}

Em termos de rede de esgoto, água, tratamento de esgoto e outras coisas mais, uma série de medidas que são tomadas para melhorar as condições sanitárias mínimas dos moradores: o saneamento básico é direito de todo indivíduo.

Esgotamento Sanitário está relacionado à higiene e manutenção da saúde pública ou pessoal. Antes dos esgotos serem programados para coletar, conduzir e retirar todos os resíduos gerados e dar-lhes o tratamento adequado, tinham como objetivo apenas de evitar enchentes urbanas.

\section{METODOLOGIA}

Esta é uma revisão bibliográfica do tipo sistemática integrativa, que segue as seguintes etapas (ver Quadro 1): $1^{\text {a }}$ ) A definição do tema, a seleção das questões norteadoras e a seleção das estratégias de pesquisa, descritores e base de dados mais eficazes no levantamento das publicações; $2^{\mathrm{a}}$ ) Escolha dos critérios de inclusão e exclusão; $3^{\text {a }}$ ) Identificação dos estudos préselecionados e selecionados através da leitura dos agentes indexadores das publicações, como resumo, palavras-chave e título, bem como organização dos estudos pré-selecionados e identificação dos estudos selecionados; 4a ) Além da análise
Em períodos de elevados índices pluviométricos, os sistemas de coleta e escoamento dos esgotos sanitários acabam sobrecarregados, favorecendo a ocorrência de vazamentos e a formação de depósitos nas ruas. Então, quais seriam as melhores estruturas para fazer o escoamento do esgotamento sanitário para que não houvesse problemas de enchentes?

Este artigo tem como objetivo trazer uma discussão sobre os pontos favoráveis e desfavoráveis de uma rede que separe água pluvial de efluentes.

das informações, da formação de bibliotecas individuais e da avaliação rigorosa dos estudos selecionados, os estudos selecionados também são classificados e a matriz composta é elaborada e utilizada; $5^{\mathrm{a}}$ ) análise, interpretação e discussão dos resultados; $6^{\mathbf{a}}$ ) Apresentação da revisão em formato de artigo, o qual contemple sugestões para pesquisas futuras. (BOTELHO; CUNHA; MACEDO, 2011; SCHMOELLER et al., 2011). Os Quadros a seguir detalha as etapas da revisão abrangente do sistema e os resultados obtidos. 
Quadro 1 - Detalhamento das etapas da Revisão Sistemática Integrativa.

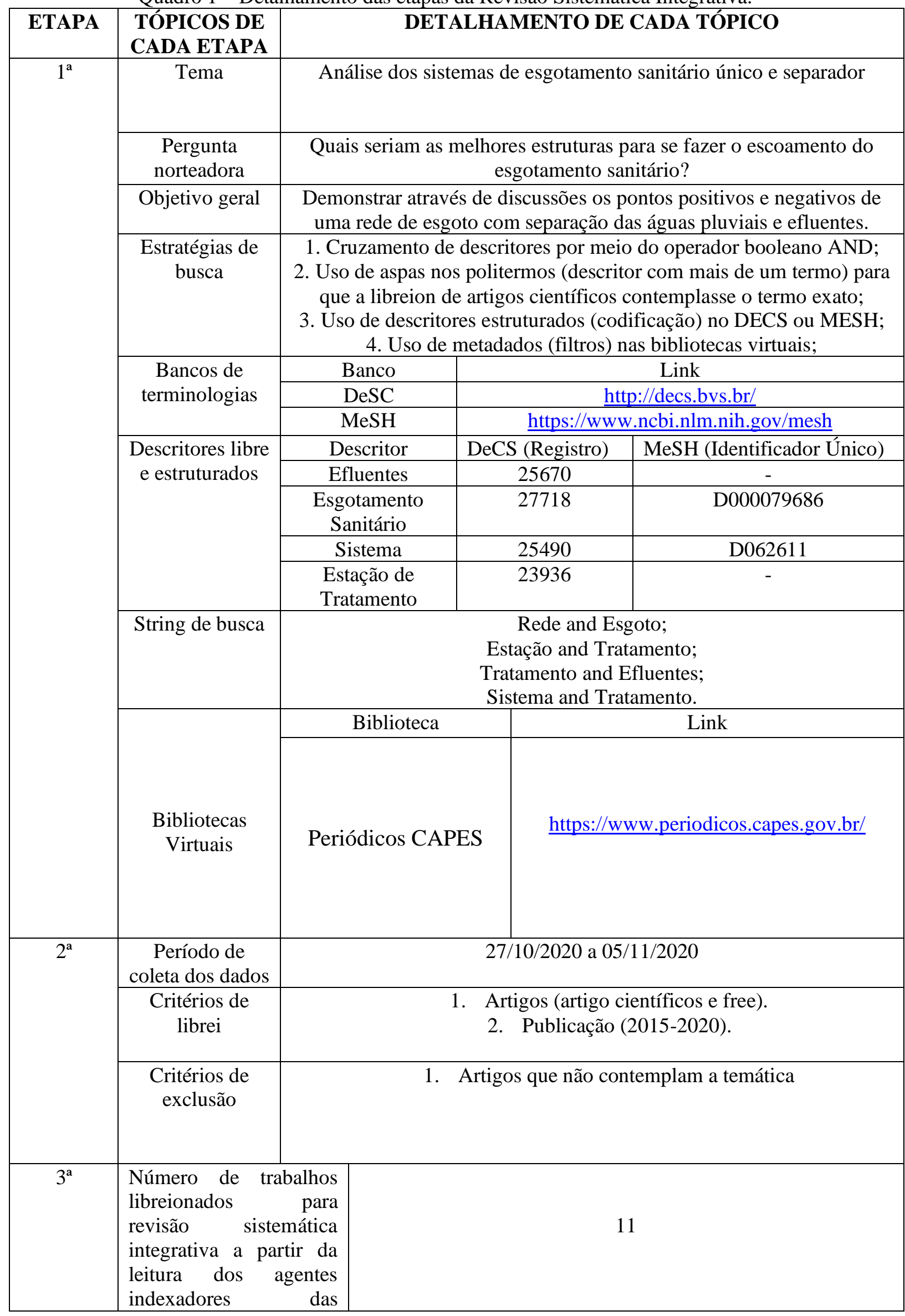




\begin{tabular}{|c|c|c|}
\hline & $\begin{array}{l}\text { publicações (tema, } \\
\text { descrição, ementa). }\end{array}$ & \\
\hline $4^{\mathrm{a}}$ & 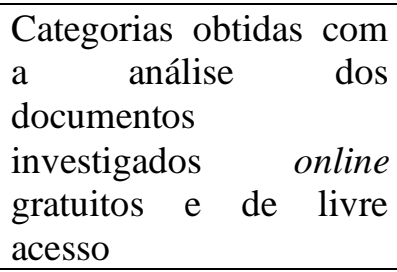 & 3 \\
\hline $5^{a}$ & $\begin{array}{l}\text { Análise, interpretação e } \\
\text { discussão dos resultados }\end{array}$ & Ver em "Resultados e Discussão" \\
\hline $6^{\mathrm{a}}$ & $\begin{array}{l}\text { Apresentação da revisão } \\
\text { em formato de artigo, o } \\
\text { qual contemple } \\
\text { propostas para estudos } \\
\text { futuros }\end{array}$ & Este Artigo completo \\
\hline
\end{tabular}

Fonte: elaborada pelos autores.

\section{RESULTADOS}

Quadro 2 - Corresponde ao total de documentos disponíveis na Plataforma obtidos por string

\begin{tabular}{|c|c|c|c|c|}
\hline String de busca & $\begin{array}{c}\text { Bases de } \\
\text { dados }\end{array}$ & $\begin{array}{c}\text { Total de } \\
\text { publicações } \\
\text { sem o filtro }\end{array}$ & $\begin{array}{l}\text { Publicações } \\
\text { disponíveis após } \\
\text { aplicar os filtros }\end{array}$ & $\begin{array}{c}\text { Publicações } \\
\text { aproveitadas na } \\
\text { Revisão Sistemática } \\
\text { Integrativa }\end{array}$ \\
\hline \multirow{4}{*}{$\begin{array}{l}\text { Rede and Esgoto } \\
\text { Estação and } \\
\text { Tratamento } \\
\text { Tratamento and } \\
\text { Efluentes } \\
\text { Sistema and } \\
\text { Tratamento }\end{array}$} & $\begin{array}{c}\text { Periódico } \\
\text { CAPES }\end{array}$ & 1.046 & 378 & 2 \\
\hline & $\begin{array}{c}\text { Periódico } \\
\text { CAPES }\end{array}$ & 2.525 & 850 & 6 \\
\hline & $\begin{array}{c}\text { Periódico } \\
\text { CAPES }\end{array}$ & 1.759 & 756 & 1 \\
\hline & $\begin{array}{c}\text { Periódico } \\
\text { CAPES }\end{array}$ & 23.073 & 8.941 & 2 \\
\hline
\end{tabular}

Quadro 3- Descrição dos documentos (artigos) de acordo com os critérios de inclusão.

\begin{tabular}{|c|c|c|c|c|c|}
\hline $\mathbf{N}^{\mathbf{0}}$ & Autor(a) & Tema & Link da publicação & $\begin{array}{c}\text { Data de } \\
\text { publicação }\end{array}$ & Conclusão \\
\hline 1 & $\begin{array}{l}\text { Graziela } \\
\text { Pinto de } \\
\text { Freitas; } \\
\text { Rosinete } \\
\text { Batista } \\
\text { dos } \\
\text { Santos } \\
\text { Ribeiro; } \\
\text { Kardelan } \\
\text { Arteiro da } \\
\text { Silva; } \\
\text { Ingrid } \\
\text { Lélis }\end{array}$ & $\begin{array}{l}\text { Sistema de } \\
\text { tratamento } \\
\text { de efluentes } \\
\text { para o } \\
\text { campus da } \\
\text { Universida } \\
\text { de Federal } \\
\text { de Campina } \\
\text { Grande na } \\
\text { cidade de } \\
\text { Pombal }\end{array}$ & $\begin{array}{l}\text { https://www.gvaa.com.br/re } \\
\text { vista/index.php/RVADS/art } \\
\text { icle/view/4525 }\end{array}$ & $01 / 04 / 2016$ & $\begin{array}{l}\text { O atual sistema de } \\
\text { tratamento do Campus } \\
\text { apresenta falhas, } \\
\text { podendo causar } \\
\text { reações adversas tanto } \\
\text { ao meio ambiente } \\
\text { como a população } \\
\text { acadêmica. } \\
\text { Com relação às } \\
\text { medidas mitigadoras } \\
\text { indicadas no estudo, } \\
\text { destacam-se: expansão } \\
\text { das fossas sépticas }\end{array}$ \\
\hline
\end{tabular}




\begin{tabular}{|c|c|c|c|c|c|}
\hline & $\begin{array}{l}\text { Ricarte } \\
\text { Cavalcant } \\
\text { e. }\end{array}$ & & & & $\begin{array}{l}\text { recuperação e } \\
\text { recomposição } \\
\text { paisagística das áreas } \\
\text { já afetadas e medidas } \\
\text { de controle ambiental } \\
\text { decorrentes do } \\
\text { armazenamento, } \\
\text { transporte e disposição } \\
\text { final do lodo. } \\
\text { O processo biológico } \\
\text { por reator UASB } \\
\text { apresenta-se como } \\
\text { alternativa viável de } \\
\text { acordo com as } \\
\text { características do local } \\
\text { a ser implantado, } \\
\text { apresentando uma } \\
\text { significativa remoção } \\
\text { de DBO/DQO, } \\
\text { apresentando baixos } \\
\text { requisitos de área e } \\
\text { baixo tempo de } \\
\text { detenção hidráulica. } \\
\text { Seu desempenho } \\
\text { justifica-se pelo fato } \\
\text { de que parte da } \\
\text { matéria orgânica é } \\
\text { mineralizada para gás } \\
\text { e água e, outra parte é } \\
\text { convertida em } \\
\text { biomassa bacteriana, } \\
\text { que pode ser } \\
\text { reutilizada no próprio } \\
\text { sistema, o que } \\
\text { representa uma grande } \\
\text { economia. }\end{array}$ \\
\hline 2 & $\begin{array}{l}\text { Randal } \\
\text { Magnani; } \\
\text { Eduardo } \\
\text { da Silva } \\
\text { Lima. }\end{array}$ & $\begin{array}{l}\text { O impacto } \\
\text { da nova } \\
\text { estação de } \\
\text { tratamento } \\
\text { de efluentes } \\
\text { do } \\
\text { município } \\
\text { de } \\
\text { Resende-RJ } \\
\text { para o } \\
\text { fortalecime } \\
\text { nto do } \\
\text { conceito de } \\
\text { cidade } \\
\text { sustentável }\end{array}$ & $\begin{array}{l}\text { https://indexlaw.org/index. } \\
\text { php/revistards/article/view/ } \\
4112\end{array}$ & $21 / 07 / 2018$ & $\begin{array}{l}\text { O presente trabalho } \\
\text { teve por finalidade } \\
\text { analisar o impacto da } \\
\text { nova estação de } \\
\text { tratamento de } \\
\text { efluentes da cidade de } \\
\text { Resende-RJ para o } \\
\text { fortalecimento do } \\
\text { conceito de cidade } \\
\text { sustentável e para a } \\
\text { preservação do meio } \\
\text { ambiente, bem de uso } \\
\text { comum de todos. } \\
\text { Como se sabe, o } \\
\text { saneamento básico na } \\
\text { sua vertente coleta e } \\
\text { tratamento de } \\
\text { efluentes é somente }\end{array}$ \\
\hline
\end{tabular}




\begin{tabular}{|c|c|c|c|c|c|}
\hline & & & & & $\begin{array}{l}\text { uma parcela do que } \\
\text { seria realmente uma } \\
\text { cidade sustentável, } \\
\text { que envolve também a } \\
\text { qualidade do ar, a } \\
\text { coleta e reciclagem do } \\
\text { lixo urbano, utilização } \\
\text { de fontes renováveis } \\
\text { de energia e até } \\
\text { mesmo a manutenção } \\
\text { de áreas verdes, dentre } \\
\text { outras. } \\
\text { A fim de se atingir o } \\
\text { objetivo proposto, } \\
\text { partiu-se da } \\
\text { necessidade de } \\
\text { apresentar os } \\
\text { conceitos de } \\
\text { consciência ecológica } \\
\text { e pegada ecológica, } \\
\text { este último } \\
\text { internacionalmente } \\
\text { reconhecido como } \\
\text { uma das formas de } \\
\text { medir a utilização, } \\
\text { pelo homem, dos } \\
\text { recursos naturais, } \\
\text { portanto, relacionado } \\
\text { com o } \\
\text { desenvolvimento } \\
\text { sustentável. [...] }\end{array}$ \\
\hline 3 & $\begin{array}{l}\text { Vanessa } \\
\text { Silva } \\
\text { Chaves; } \\
\text { Erwin } \\
\text { Henrique } \\
\text { Meneses } \\
\text { Schneider } \\
\text {; Arthur } \\
\text { Silva } \\
\text { Passos } \\
\text { Lima; } \\
\text { Luciana } \\
\text { Coêlho } \\
\text { Mendonç } \\
\text { a. }\end{array}$ & $\begin{array}{l}\text { Desempenh } \\
\text { o das } \\
\text { estações de } \\
\text { tratamento } \\
\text { do esgoto } \\
\text { de Aracaju }\end{array}$ & $\begin{array}{l}\text { http://revistadae.com.br/arti } \\
\text { gos/artigo_edicao_209_n_1 } \\
\text { 699.pdf }\end{array}$ & $01 / 01 / 2018$ & $\begin{array}{l}\text { Diante dos resultados } \\
\text { obtidos, verifica-se } \\
\text { que a } \\
\text { ERQ Oeste e a ETE } \\
\text { Visconde de Maracaju } \\
\text { cumpriram } \\
\text { integralmente todas as } \\
\text { condições para os } \\
\text { parâmetros analisados, } \\
\text { no que diz respeito às } \\
\text { exigências } \\
\text { da legislação } \\
\text { ambiental vigente, a } \\
\text { Resolução } \\
\text { Conama 430. } \\
\text { As demais estações } \\
\text { descumpriram a } \\
\text { legislação } \\
\text { em algum momento, } \\
\text { com destaque para a } \\
\text { ETE }\end{array}$ \\
\hline
\end{tabular}




\begin{tabular}{|c|c|c|c|c|c|}
\hline & & & & & $\begin{array}{l}\text { Orlando Dantas, que } \\
\text { apresentou o pior } \\
\text { resultado, } \\
\text { ultrapassando o limite } \\
\text { tolerado de DBO em } \\
\text { duas } \\
\text { coletas e de sólidos } \\
\text { sedimentáveis em uma } \\
\text { coleta. } \\
\text { O baixo desempenho } \\
\text { dessa estação deve-se, } \\
\text { dentre } \\
\text { outros motivos, à } \\
\text { qualidade do esgoto } \\
\text { bruto } \\
\text { recebido, inclusive, } \\
\text { DBO superior aos } \\
\text { valores típicos, } \\
\text { fator que a torna mais } \\
\text { suscetível ao } \\
\text { descumprimento } \\
\text { da legislação. [...] }\end{array}$ \\
\hline 4 & $\begin{array}{l}\text { Claudinei } \\
\text { Fonseca } \\
\text { Souza; } \\
\text { Reinaldo } \\
\text { Gaspar } \\
\text { Bastos; } \\
\text { Marcus } \\
\text { Paulo de } \\
\text { Moraes } \\
\text { Gomes; } \\
\text { André } \\
\text { Arashiro } \\
\text { Pulschen. }\end{array}$ & $\begin{array}{l}\text { Eficiência } \\
\text { de estação } \\
\text { de } \\
\text { tratamento } \\
\text { de esgoto } \\
\text { doméstico } \\
\text { visando } \\
\text { reuso } \\
\text { agrícola }\end{array}$ & $\begin{array}{l}\text { http://www.scielo.br/scielo. } \\
\text { php?script=sci_arttext\&pid } \\
=\text { S1980- } \\
\text { 993X2015000300587 }\end{array}$ & $01 / 09 / 2015$ & $\begin{array}{l}\text { Nas condições } \\
\text { experimentais pôde-se } \\
\text { concluir que a ETE } \\
\text { apresenta ser eficiente } \\
\text { na capacidade de } \\
\text { depuração de matéria } \\
\text { orgânica e nutrientes. } \\
\text { O efluente final é } \\
\text { composto por } \\
\text { elementos de } \\
\text { importância agrícola } \\
\text { tais como nitrogênio, } \\
\text { fósforo, cálcio e } \\
\text { potássio e, juntamente } \\
\text { com a carga de } \\
\text { matéria orgânica e } \\
\text { sais, enquadra-se, nas } \\
\text { determinações da } \\
\text { NBR 13.969/1997 } \\
\text { (ABNT, 1997) para } \\
\text { reutilização na } \\
\text { agricultura. } \\
\text { Apesar da eficácia da } \\
\text { ETE na remoção de } \\
\text { matéria orgânica e da } \\
\text { capacidade de } \\
\text { remoção de coliformes } \\
\text { totais e E. coli, } \\
\text { observa-se a } \\
\text { necessidade de } \\
\text { tratamento terciário } \\
\text { para remoção de }\end{array}$ \\
\hline
\end{tabular}




\begin{tabular}{|c|c|c|c|c|c|}
\hline & & & & & $\begin{array}{l}\text { patógenos, porém sem } \\
\text { descartar } \\
\text { monitoramentos } \\
\text { periódicos da } \\
\text { salinidade do solo. }\end{array}$ \\
\hline 5 & $\begin{array}{l}\text { Fabrício } \\
\text { Oliveira } \\
\text { Dias; } \\
\text { Jémison } \\
\text { Mattos } \\
\text { dos } \\
\text { Santos; } \\
\text { Sampaio } \\
\text { de Jesus. }\end{array}$ & $\begin{array}{l}\text { Tratamento } \\
\text { de esgoto } \\
\text { doméstico a } \\
\text { partir di } \\
\text { sistema } \\
\text { Leito de } \\
\text { Raízes: } \\
\text { experiência } \\
\text { em uma } \\
\text { pequena } \\
\text { comunidad } \\
\text { e rural do } \\
\text { semiárido } \\
\text { brasileiro. }\end{array}$ & $\begin{array}{l}\text { https://periodicos2.uesb.br/i } \\
\text { ndex.php/geo/article/view/4 } \\
392\end{array}$ & $01 / 12 / 2018$ & $\begin{array}{l}\text { Confirma-se que o } \\
\text { manejo inadequado } \\
\text { das águas servidas, o } \\
\text { descarte de efluentes } \\
\text { nos solos e a ausência } \\
\text { do saneamento básico } \\
\text { na EFACI constituem- } \\
\text { se graves problemas } \\
\text { locais, que ainda não } \\
\text { foram solucionados. } \\
\text { Uma vez que a } \\
\text { inexistência de } \\
\text { estações de tratamento } \\
\text { de efluentes } \\
\text { domésticos contribui } \\
\text { decisivamente para a } \\
\text { poluição e a possível } \\
\text { contaminação dos } \\
\text { corpos hídricos } \\
\text { superficiais e } \\
\text { subterrâneos, dos } \\
\text { solos e a propagação } \\
\text { de patologias } \\
\text { veiculadas } \\
\text { hidricamente. } \\
\text { Dentre as alternativas } \\
\text { para equacionar as } \\
\text { questões supracitadas, } \\
\text { sinaliza-se } \\
\text { destacadamente o uso } \\
\text { e a aplicação da } \\
\text { técnica de tratamento } \\
\text { de efluentes } \\
\text { domésticos por meio } \\
\text { do sistema de leito de } \\
\text { raízes/leitos } \\
\text { cultivados, devido ao } \\
\text { baixo custo de } \\
\text { implantação, o } \\
\text { reduzido consumo de } \\
\text { energia e manutenção, } \\
\text { bem como por ser um } \\
\text { sistema relativamente } \\
\text { simples de construir. } \\
\text { Além disso, a } \\
\text { promoção de } \\
\text { melhorias das } \\
\text { condicões sanitárias e }\end{array}$ \\
\hline
\end{tabular}




\begin{tabular}{|c|c|c|c|c|c|}
\hline & & & & & $\begin{array}{l}\text { estéticas na paisagem. } \\
{[\ldots]}\end{array}$ \\
\hline 6 & $\begin{array}{l}\text { Gustavo } \\
\text { Stolzenbe } \\
\text { rg } \\
\text { Colares; } \\
\text { Fagner } \\
\text { Pereira da } \\
\text { Silva; } \\
\text { Gleison } \\
\text { de Souza } \\
\text { Celente; } \\
\text { Julia } \\
\text { Fernanda } \\
\text { Radkte; } \\
\text { Ennio } \\
\text { Leandro } \\
\text { Machado. }\end{array}$ & $\begin{array}{l}\text { Sistema } \\
\text { integrado } \\
\text { de } \\
\text { tratamento } \\
\text { de efluentes } \\
\text { sanitários } \\
\text { com } \\
\text { reatores } \\
\text { anaeróbicos } \\
\text { sequenciais } \\
\text { em } \\
\text { Batelada e } \\
\text { Wetlands } \\
\text { construídos } \\
\text { de fluxos } \\
\text { alternados }\end{array}$ & $\begin{array}{l}\text { https://online.unisc.br/seer/i } \\
\text { ndex.php/tecnologica/articl } \\
\text { e/view/10496 }\end{array}$ & $01 / 01 / 2018$ & $\begin{array}{l}\text { Os resultados obtidos } \\
\text { com o sistema } \\
\text { integrado WCFFH+ } \\
\text { WCFFA+ WCFV } \\
\text { foram satisfatórios, } \\
\text { principalmente em } \\
\text { termos de remoção N- } \\
\text { NH3, fósforo solúvel e } \\
\text { turbidez. } \\
\text { Considerando a } \\
\text { simplicidade de } \\
\text { projeto, construção e } \\
\text { manutenção, bem } \\
\text { como potencial baixo } \\
\text { custo, o sistema } \\
\text { apresenta um grande } \\
\text { potencial para } \\
\text { aplicação em zonas } \\
\text { rurais e/ou de baixa } \\
\text { densidade } \\
\text { populacional. É } \\
\text { importante destacar } \\
\text { também que as } \\
\text { diferenças encontradas } \\
\text { nos resultados das } \\
\text { análises } \\
\text { (principalmente no } \\
\text { efluente bruto) entre } \\
\text { os meses de fevereiro } \\
\text { e de março ocorreram } \\
\text { devido ao início do } \\
\text { semestre letivo, } \\
\text { momento no qual } \\
\text { ocorreu um aumento } \\
\text { significativo de } \\
\text { pessoas na } \\
\text { universidade. Espera- } \\
\text { se que nos meses } \\
\text { posteriores aos } \\
\text { resultados obtidos, até } \\
\text { o presente momento, o } \\
\text { sistema possa } \\
\text { apresentar-se mais } \\
\text { eficiente no } \\
\text { tratamento dos } \\
\text { efluentes } \\
\text { (principalmente em } \\
\text { relação a remoção de } \\
\text { COT), devido ao } \\
\text { desenvolvimento do } \\
\text { sistema radicular das } \\
\text { macrófitas, uma vez }\end{array}$ \\
\hline
\end{tabular}




\begin{tabular}{|c|c|c|c|c|c|}
\hline & & & & & $\begin{array}{l}\text { que as mudas } \\
\text { utilizadas eram } \\
\text { relativamente novas e } \\
\text { possuíam raízes pouco } \\
\text { desenvolvidas. [...] }\end{array}$ \\
\hline 7 & $\begin{array}{l}\text { Rodrigo } \\
\text { Braga } \\
\text { Moruzzi. }\end{array}$ & $\begin{array}{l}\text { Estimativa } \\
\text { do } \\
\text { lançamento } \\
\text { de água } \\
\text { pluvial no } \\
\text { sistema de } \\
\text { coleta e } \\
\text { transporte } \\
\text { de esgoto } \\
\text { sanitário } \\
\text { por meio de } \\
\text { práticas de } \\
\text { aproveitam } \\
\text { ento em } \\
\text { residências } \\
\text { unifamiliar } \\
\text { es }\end{array}$ & $\begin{array}{l}\text { http://www.scielo.br/scielo. } \\
\text { php?script=sci_serial\&pid= } \\
1413- \\
4152 \& \operatorname{lng}=\text { en\&nrm=iso }\end{array}$ & $01 / 03 / 2016$ & $\begin{array}{l}\text { Os resultados } \\
\text { apontaram que a } \\
\text { eficiência do sistema } \\
\text { de aproveitamento } \\
\text { de água pluvial } \\
\text { (SAAP) variou de } 24 \text { a } \\
87 \% \text { para áreas de } \\
\text { cobertura de } \\
\text { telhado de } 4 \text { a } 300 \\
\text { m2.hab.-1 e volumes } \\
\text { de reservatórios de } 0,5 \\
\text { a } 3,0 \text { m3.hab.-1, } \\
\text { os quais } \\
\text { corresponderam a } \\
\text { volumes ofertados } \\
\text { médios de água } \\
\text { pluvial da ordem } \\
\text { de } 8 \text { a } 370 \text { L/hab.dia } \\
\text { para a demanda média } \\
\text { otimizada, para } 0,5 \\
\text { m3.hab.-1. } \\
\text { O lançamento de água } \\
\text { pluvial na rede } \\
\text { coletora de } \\
\text { esgotamento sanitário } \\
\text { apresenta valores } \\
\text { menores que } 30 \% \text { para } \\
\text { áreas específicas de } \\
\text { cobertura de } 4 \text { a } \\
\text { 25 m2.hab.-1, com } \\
\text { reservação de } 0,5 \\
\text { m3.hab.-1 para todas } \\
\text { as faixas de consumo } \\
\text { per capita simuladas } \\
\text { (120,150, 180 e } 250 \\
\text { L.hab.-1.dia-1), } \\
\text { indicando que a } \\
\text { descargas } \\
\text { em bacias sanitárias } \\
\text { não são plenamente } \\
\text { atendidas nessas } \\
\text { condições. } \\
\text { Para } 3 \text { m3 de } \\
\text { reservatório.hab.-1, } \\
\text { valores da ordem de } \\
\text { 15 m2 de } \\
\text { cobertura.hab.-1 são } \\
\text { suficientes para }\end{array}$ \\
\hline
\end{tabular}




\begin{tabular}{|c|c|c|c|c|c|}
\hline & & & & & $\begin{array}{l}\text { atender plenamente a } \\
\text { bacia } \\
\text { sanitária, com base no } \\
\text { consumo de } 120 \\
\text { L.hab-1.dia-1. Para } \\
150 \text { L.hab-1. } \\
\text { dia-1, a descarga em } \\
\text { bacia foi plenamente } \\
\text { atendida a partir de } \\
\text { áreas } \\
\text { específicas de } \\
\text { cobertura de } 20 \text { e } 35 \\
\text { m2/hab., para } 3 \text { e } 0,5 \\
\text { m3 de reservatório. } \\
\text { hab.-1, } \\
\text { respectivamente. [...] }\end{array}$ \\
\hline 8 & $\begin{array}{l}\text { Murilo } \\
\text { Bertolino; } \\
\text { Jonas } \\
\text { Heitor } \\
\text { Kondages } \\
\text { ki; Regina } \\
\text { Weinschu } \\
\text { tz. }\end{array}$ & $\begin{array}{l}\text { Água de } \\
\text { chuva } \\
\text { domiciliar } \\
\text { no esgoto } \\
\text { separador } \\
\text { absoluto }\end{array}$ & $\begin{array}{l}\text { http://revistadae.com.br/arti } \\
\text { gos/artigo_edicao_213_n_1 } \\
\text { 741.pdf }\end{array}$ & $01 / 10 / 2018$ & $\begin{array}{l}\text { Os dados } \\
\text { georreferenciados das } \\
\text { vistorias ambientais } \\
\text { (SANEPAR, 2012) } \\
\text { para afluxo de água de } \\
\text { chuva } \\
\text { predial na rede de } \\
\text { esgoto foram } \\
\text { adequados para } \\
\text { criar um mapa de } \\
\text { densidade de } \\
\text { irregularidades } \\
\text { para a bacia com } \\
\text { maior histórico de } \\
\text { acréscimo de } \\
\text { vazão na estação de } \\
\text { tratamento durante } \\
\text { período } \\
\text { de chuva, a bacia do } \\
\text { Rio Belém e para } \\
\text { identificar as } \\
\text { áreas com maiores } \\
\text { densidade de } \\
\text { irregularidades. [...] }\end{array}$ \\
\hline 9 & $\begin{array}{l}\text { Gisele } \\
\text { Silva de } \\
\text { Souza; } \\
\text { Samanta } \\
\text { Tolentino } \\
\text { Cecconell } \\
\text { o; Luana } \\
\text { Nunes } \\
\text { Centeno. }\end{array}$ & $\begin{array}{l}\text { Redes } \\
\text { ociosas: um } \\
\text { estudo de } \\
\text { caso sobre } \\
\text { a percepção } \\
\text { da } \\
\text { população } \\
\text { do bairro } \\
\text { Laranja } \\
\text { quanto à } \\
\text { obrigatorie } \\
\text { dade da } \\
\text { ligação dos } \\
\text { ramais }\end{array}$ & $\begin{array}{l}\text { http://periodicos.ifsul.edu.b } \\
\text { r/index.php/thema/article/vi } \\
\text { ew/882 }\end{array}$ & $01 / 10 / 2018$ & $\begin{array}{l}\text { Pode-se concluir que } \\
\text { dentre os entrevistados } \\
\text { houve uma } \\
\text { preocupação e } \\
\text { interesse em se } \\
\text { adequar à legislação } \\
\text { municipal para } \\
\text { promover a qualidade } \\
\text { de vida da população e } \\
\text { consequentemente da } \\
\text { salubridade ambiental } \\
\text { da Laguna dos Patos. } \\
\text { Provavelmente este } \\
\text { interesse em realizar a }\end{array}$ \\
\hline
\end{tabular}




\begin{tabular}{|c|c|c|c|c|c|}
\hline & & $\begin{array}{l}\text { prediais à } \\
\text { rede } \\
\text { pública } \\
\text { coletora de } \\
\text { esgotos }\end{array}$ & & & $\begin{array}{l}\text { ligação predial dos } \\
\text { esgotos sanitários à } \\
\text { rede pública se dê em } \\
\text { virtude do alto padrão } \\
\text { de vida da população } \\
\text { entrevistada que } \\
\text { atrelada à alta } \\
\text { escolaridade, permite } \\
\text { que } 72 \% \text { dos } \\
\text { entrevistados já } \\
\text { estejam com seu } \\
\text { sistema de } \\
\text { esgotamento } \\
\text { conectado à rede. Com } \\
\text { relação à ociosidade } \\
\text { da rede coletora, este } \\
\text { estudo pôde } \\
\text { demonstrar que das } \\
\text { residências } \\
\text { entrevistadas, apenas } \\
85 \text { haviam realizado a } \\
\text { ligação à rede, } \\
\text { representando } 18,4 \% \\
\text { do total das } \\
\text { residências ligadas. } \\
\text { Deste modo, neste } \\
\text { estudo concluiu-se que } \\
\text { a rede coletora de } \\
\text { esgotos no bairro } \\
\text { Laranjal apresenta } \\
81,6 \% \text { de ociosidade. } \\
\text { O fator econômico é o } \\
\text { grande empecilho para } \\
\text { que haja a ligação dos } \\
\text { ramais prediais de } \\
\text { esgoto sanitário à rede } \\
\text { pública de coleta de } \\
\text { esgotos, visando } \\
\text { diminuir a ociosidade } \\
\text { da rede. } \\
\end{array}$ \\
\hline 10 & $\begin{array}{l}\text { Gustavo } \\
\text { Paiva } \\
\text { Weyne } \\
\text { Rodrigues } \\
\text {; } \\
\text { Guilherm } \\
\text { e Marques } \\
\text { Farias; } \\
\text { Luís } \\
\text { Henrique } \\
\text { Magalhãe } \\
\text { s Costa; } \\
\text { Marco } \\
\text { Aurélio }\end{array}$ & $\begin{array}{l}\text { Otimização } \\
\text { do traçado } \\
\text { de redes } \\
\text { coletoras de } \\
\text { esgoto } \\
\text { sanitário } \\
\text { via } \\
\text { algoritmo } \\
\text { genético }\end{array}$ & $\begin{array}{l}\text { http://revistadae.com.br/arti } \\
\text { gos/artigo_edicao_222_n_1 } \\
\text { 841.pdf }\end{array}$ & $01 / 03 / 2020$ & $\begin{array}{l}\text { Diante da importância } \\
\text { de uma rede de esgoto } \\
\text { sanitário para a } \\
\text { promoção da saúde } \\
\text { pública e do } \\
\text { elevado custo de } \\
\text { execução, faz-se cada } \\
\text { vez mais } \\
\text { necessária a aplicação } \\
\text { de métodos de } \\
\text { otimização } \\
\text { visando a diminuir os } \\
\text { custos envolvidos, de }\end{array}$ \\
\hline
\end{tabular}




\begin{tabular}{|c|c|c|c|c|c|}
\hline & $\begin{array}{l}\text { Holanda } \\
\text { de Castro. }\end{array}$ & & & & $\begin{array}{l}\text { forma a buscar o } \\
\text { máximo } \\
\text { aproveitamento do } \\
\text { capital } \\
\text { investido por órgãos } \\
\text { governamentais. } \\
\text { O resultado obtido } \\
\text { com o modelo em } \\
\text { questão } \\
\text { foi satisfatório. Além } \\
\text { disso, vale destacar a } \\
\text { utilização } \\
\text { do sentido do } \\
\text { escoamento como } \\
\text { variável } \\
\text { de decisão, pois a } \\
\text { topografia tem } \\
\text { impacto direto } \\
\text { e bastante expressivo } \\
\text { no valor do custo final } \\
\text { de } \\
\text { uma rede de esgoto. } \\
\text { [...] }\end{array}$ \\
\hline 11 & $\begin{array}{l}\text { Thiago } \\
\text { Zschornac } \\
\mathrm{k} \text {; } \\
\text { Therezinh } \\
\text { a Maria } \\
\text { Novais de } \\
\text { Oliveira. }\end{array}$ & $\begin{array}{l}\text { Avaliação } \\
\text { do impacto } \\
\text { da } \\
\text { implantaçã } \\
\text { o do } \\
\text { sistema de } \\
\text { esgotament } \\
\text { o sanitário } \\
\text { na } \\
\text { qualidade } \\
\text { da água da } \\
\text { Bacia } \\
\text { Hidrográfic } \\
\text { a do Rio } \\
\text { Cachoeira, } \\
\text { em } \\
\text { Joinville, } \\
\text { Santa } \\
\text { Catarina }\end{array}$ & $\begin{array}{l}\text { http://revistadae.com.br/arti } \\
\text { gos/artigo_edicao_212_n_1 } \\
\text { 727.pdf }\end{array}$ & 01/09/2018 & $\begin{array}{l}\text { A compreensão das } \\
\text { relações entre } \\
\text { saneamento, } \\
\text { saúde e meio ambiente } \\
\text { constitui uma das } \\
\text { etapas } \\
\text { mais importantes no } \\
\text { planejamento de } \\
\text { qualquer } \\
\text { política pública. Todo } \\
\text { investimento requer } \\
\text { um retorno, } \\
\text { seja ele mensurável ou } \\
\text { não. No caso do } \\
\text { investimento } \\
\text { em saneamento, } \\
\text { especificamente no } \\
\text { componente de } \\
\text { esgotamento sanitário, } \\
\text { o maior } \\
\text { retorno reside na } \\
\text { melhoria das } \\
\text { condições ambientais, } \\
\text { sociais e de saúde } \\
\text { pública. } \\
\text { A partir deste estudo } \\
\text { realizado na Bacia } \\
\text { Hidrográfica } \\
\text { do Rio Cachoeira, em } \\
\text { Joinville, foi possível }\end{array}$ \\
\hline
\end{tabular}




\begin{tabular}{|l|l|l|}
\hline & $\mid \begin{array}{l}\mid \\
\end{array}$ & $\begin{array}{l}\text { constatar que as obras } \\
\text { de expansão do } \\
\text { sistema de } \\
\text { esgotamento sanitário } \\
\text { realizadas no } \\
\text { município } \\
\text { vêm apresentando } \\
\text { impacto positivo na } \\
\text { qualidade } \\
\text { da água dos rios que a } \\
\text { compõem. Fato que } \\
\text { ajuda a } \\
\text { confirmar que os } \\
\text { investimentos em } \\
\text { esgotamento } \\
\text { sanitário representam } \\
\text { a principal solução } \\
\text { para a } \\
\text { despoluição de } \\
\text { qualquer rio urbano. } \\
\text { [...] }\end{array}$ \\
\hline
\end{tabular}

Fonte: elaborada pelos autores.

O corpo textual foi analisado por meio da frequência de palavras, que originou a nuvem de palavras (Figura 1) criada na Plataforma online WordArt. Esta ferramenta agrupa e organiza graficamente as palavras-chave evidenciando-as as mais frequentes.

Figura 1 - Nuvem de palavras

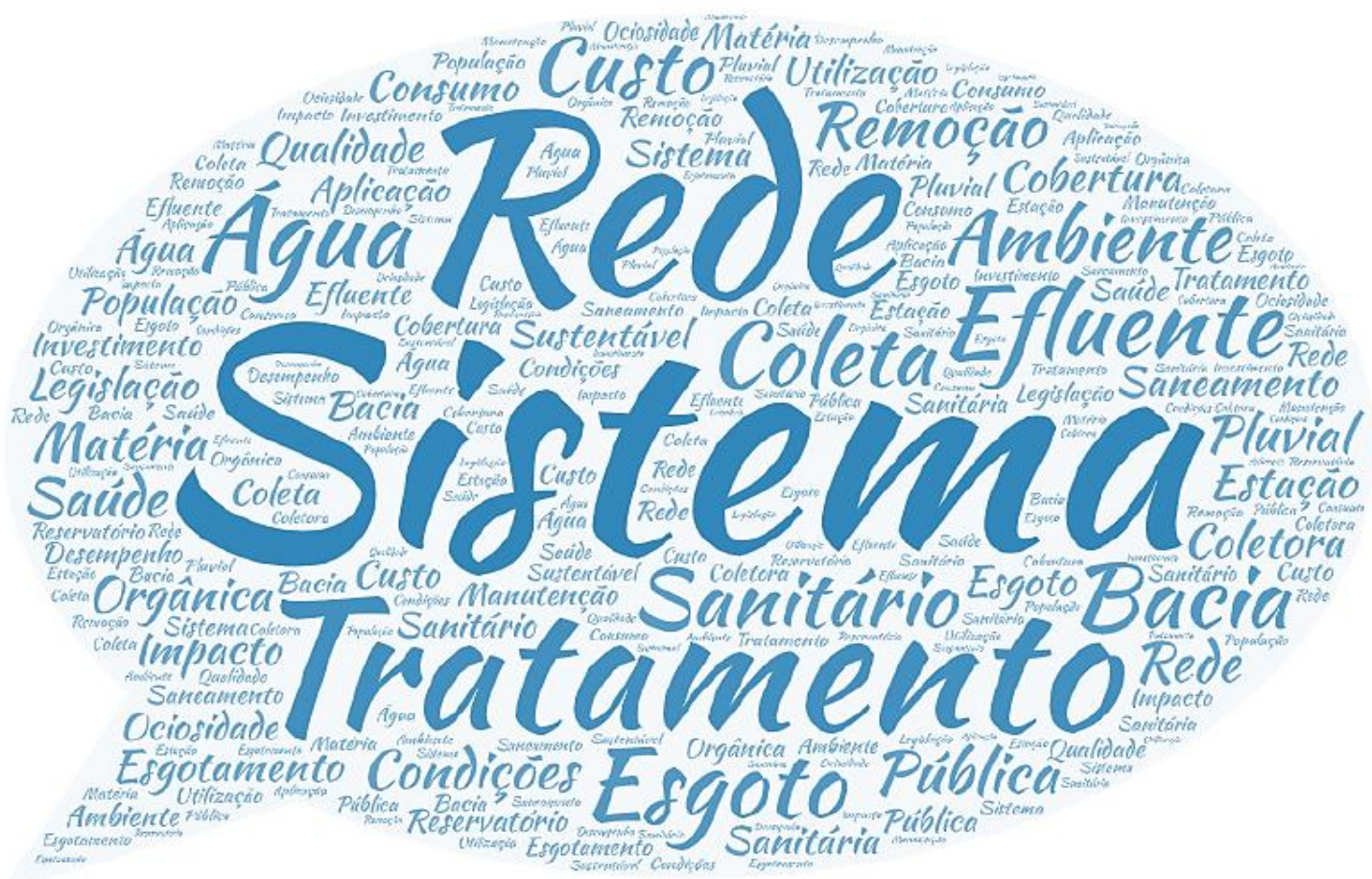

Fonte: elaborada pelos autores. 
Por meio da Figura 1, foi possível observar que as palavras em evidência na nuvem pertencem as categorias desenvolvidas a partir da análise de conteúdo de Bardin. Todas as categorias derivam da sua frequência (Tabela 1), que diz respeito ao seu quadro referencial. Em consonância ao objetivo deste trabalho, optou-se por descrever as palavras que apresentaram frequência total no texto e, a partir de seus sentidos nos campos textuais, tinham maior relevância para as representações sociais sobre os tipos de redes hidráulicas e as suas funcionalidades em questão do escoamento e tratamento de esgoto, como apresentado na Figura1.

Tabela 1. Frequência das palavras presentes nos textos publicados na Plataforma Periódico CAPES

\begin{tabular}{|c|c|c|}
\hline PALAVRAS & FREQUÊNCIA & CATEGORIAS \\
\hline Sistema & 11 & 14 \\
\hline Rede & 11 & 4 \\
\hline Tratamento & 8 & 0 \\
\hline Efluente & 8 & 0 \\
\hline Esgoto & 8 & 13 \\
\hline Água & 7 & 15 \\
\hline Sanitário & 7 & 0 \\
\hline Ambiente & 6 & 0 \\
\hline Remoção & 6 & 0 \\
\hline Bacia & 6 & 0 \\
\hline Coleta & 5 & 0 \\
\hline Condições & 5 & 0 \\
\hline Custo & 5 & 0 \\
\hline Esgotamento & 5 & 6 \\
\hline Pública & 5 & 0 \\
\hline Matéria & 4 & 0 \\
\hline Orgânica & 4 & 0 \\
\hline
\end{tabular}




\begin{tabular}{|c|c|c|}
\hline Saneamento & 4 & 0 \\
\hline Qualidade & 4 & 0 \\
\hline Legislação & 4 & 0 \\
\hline Cobertura & 4 & 0 \\
\hline População & 3 & 0 \\
\hline Impacto & 3 & 0 \\
\hline Estação & 3 & 0 \\
\hline Sustentável & 3 & 0 \\
\hline Utilização & 3 & 0 \\
\hline Manutenção & 3 & 0 \\
\hline Aplicação & 3 & 0 \\
\hline Consumo & 3 & 0 \\
\hline Sanitária & 3 & 0 \\
\hline Pluvial & 3 & 0 \\
\hline Reservatório & 3 & 0 \\
\hline Coletora & 3 & 0 \\
\hline Ociosidade & 3 & 0 \\
\hline Saúde & 3 & 0 \\
\hline Investimento & 3 & 0 \\
\hline Desempenho & 2 & 0 \\
\hline
\end{tabular}

Fonte: elaborada pelos autores. 


\section{DISCUSSÕES}

\section{Sistema de Esgotamento Unitário}

Sistema Coletivo Unitário soma as vazões das redes dos esgotos com as águas pluviais em uma mesma tubulação. No Brasil tem sistemas pluviométricos irregulares, onde ocorre diferentes vazões em períodos de anos diferentes. Para conceber um sistema de esgotamento unitário é preciso dimensiona-lo para captar a água da chuva nas suas maiores vazões, e em períodos mais secos o sistema superdimensionado ficará obsoleto, com pouca vazão passando pela tubulação que seria apenas a vazão dos esgotos, elevando o custo em relação a construção do sistema de coleta de água de chuva junto com o esgoto.

Em dias de chuvas mais intensas será necessário utilizar um extravasor, uma vez que é necessário coletar a água excedente de chuva, onde torna-se um risco de refluxo do esgoto sanitário para as residências. E em casos de cheias teria extravasamento de bueiros ou então na própria estrutura domiciliar se ocorrer esse retorno do esgoto, e em grande cheias se tem a ocorrência desses extravasamentos do esgoto coletado, o que pode ocorrer mau cheiro em sistema de boca-de-lobo nas drenagens urbanas. (MEDEIROS, 2020).

\section{Sistema de Esgotamento Separador} Absoluto

Nesse sistema separador absoluto as águas pluviais e água residuária é totalmente separada. São coletadas por tubulações diferentes, são encaminhadas para destinos diferentes. Então é dada essa separação da rede de drenagem com a rede de esgoto, onde proporciona um menor custo em relação às canalizações no qual será utilizado um diâmetro menor para coletar tanto água da chuva quanto água do esgoto.

Com relação a água da drenagem pode-se fazer a disposição dessa água coletada em locais mais próximos de onde ela foi gerada, não precisando afastar totalmente essa água como acontece no sistema de esgotamento sanitário. E uma vez que se tem um menor volume de esgoto chegando na ETE, se tem um menor custo com tratamento associado a essa menor vazão.

Adotando o sistema separador absoluto é necessário se ter controle e adotar fiscalização, monitoramento para que evite o caso de haver ligações clandestinas de esgoto no sistema de drenagem e o de drenagem em sistema de esgotamento sanitário. (MEDEIROS, 2020). 
Idealização de Coleta numa Residência

No sistema de esgotamento sanitário separador absoluto, em relação ao esgoto, ele sai das instalações hidrossanitárias de uma residência, é encaminhada para a caixa de inspeção e dessa caixa de inspeção vai haver uma ligação domiciliar a rede coletora pública de coleta de esgoto.

\section{CONCLUSÕES}

Essa pesquisa tinha como finalidade discutir as medidas que buscam modificar e prevenir problemas relacionados ao abastecimento de água, assim como o manejo de água pluvial, coleta e tratamento de esgoto. Buscando entender como a falta de controle e projeção dessas medidas pode acarretar problemas a população, e prejuízos orçamentários aos municípios.

Traz à tona, que a precariedade dos processos utilizados no Brasil, é o grande ofensor em relação a evolução desse trabalho, causando assim diversos problemas que custam em sua maioria, problemas de saúde a população. Observamos que o esgotamento sanitário a princípio tinha como única função e/ou objetivo evitar enchentes nas zonas urbanas. Com a evolução de tais processos temos a evolução do tratamento da rede de esgoto, uma mudança comportamental em relação
A água pluvial vai ser coletada nos telhados onde pode ser encaminhada, por exemplo, para uma boca-de-lobo e dessa boca-de-lobo a água vai ser encaminhada para uma galeria.

Portanto ocorre uma separação da água da chuva com a água do esgoto em tubulações e em canalizações diferentes. (MEDEIROS, 2020).

aos cuidados com a população e mais cuidado com o deposito dos dejetos.

As melhores estruturas do esgotamento sanitário para evitar problemas ocasionados por enchentes são as que possuem o sistema de esgotamento separador absoluto, em que os tipos de águas vão por tubulações diferentes, mas como no Brasil ainda é usado o Sistema de Saneamento Unitário, a condução do conjunto escoamentos sanitários e das aguas pluviais vão para o mesmo destino, onde normalmente vão diretamente para os canais e rios.

Vale salientar que esse estudo não esgota as possibilidades de investigação, desta forma deixa-se como sugestão para pesquisas futuras: mapear as atribuições de cada processo utilizado e propor uma distribuição mais eficiente à luz dos processos voltados ao esgotamento sanitário. 


\section{REFERÊNCIAS}

SILVA, Eduardo Cabral da; Resíduos Sólidos. Aula do dia 17 de novembro de 2020. Disponível em: < https://us02web.zoom.us/rec/play/0J9f0TV C7xZcLz3e6yFtEzET0cLGTDqnfNjAHn4 O23a4IHKufaeXtTA9kmQpWilfrvmKl6y WG_TN_gY4.z2JPNW_Bh8HF96QC?con tinueMode $=$ true\&_x_zm_rtaid=ECB_OUT 8QmaaapTETjybmA.1605983046113.2e8f 9a48195e580f9a28ed7c38c02ebf\&_x_zm_ rhtaid $=316>$. Acesso em: 21 nov. 2020.

MEDEIROS, Giovana. Saneamento Ambiental, Sistema de Esgotamento Sanitário (Sistema Unitário e Sistema Separador). Disponível em: https://www.youtube.com/watch?v=gjDm GcRMcoA. Acesso em: 21 nov. 2020.

FREITAS, Graziela Pinto de; RIBEIRO, Rosinete Batista dos Santos; SILVA, Kardelan Arteiro da; CAVALCANTE, Ingrid Lélis Ricarte. Sistema de tratamento de efluentes para o campus da Universidade Federal de Campina Grande na cidade de Pombal. Revista Verde de Agroecologia e Desenvolvimento Sustentável. V. 11, No 2, p. 08-12, 2016. Disponível em: $<\underline{\text { Revista Verde de }}$ Agroecologia e Desenvolvimento Sustentável (gvaa.com.br)>. Acesso em: 05 nov. 2020.

MAGNANI, Randal; LIMA, Eduardo da Silva; O impacto da nova estação de tratamento de efluentes de município de Resende-RJ para o fortalecimento do conceito de cidade sustentável. Revista de Direito e Sustentabilidade. Salvador v. 4, n. 1, p. 19 - 38 Jan/Jun. 2018.

CHAVES, Vanessa Silva; SCHNEIDER, Erwin Henrique Meneses; LIMA, Arthur Silva Passos; MENDONÇA. Luciana Coêlho; Desempenho das estações de tratamento do esgoto de Aracaju. Revista DAE. núm. 209 | vol. 66 | janeiro a março de 2018.
SOUZA, Claudinei Fonseca; BASTOS, Reinaldo Gaspar; GOMES, Marcus Paulo de Moraes; PULSCHEN, André Arashiro; Eficiência de estação de tratamento de esgoto doméstico visando reuso agrícola. Revista Ambiente \& Água. vol. 10 n. 3 Taubaté - Jul. / Sep. 2015. Disponível em: $<$ Ambiente e Agua - An Interdisciplinary Journal of Applied Science (ambiagua.net)>. Acesso em: 05 nov. 2020.

DIAS, Fabrício Oliveira; SANTOS, Jémison Mattos dos; JESUS, Sampaio de; Tratamento de esgoto doméstico a partir do sistema leito de raízes: Experiência em uma pequena comunidade rural do semiárido brasileiro. Revista Geopauta. Volume 02, $\mathrm{n}^{\circ} .02,2018$

Setembro/dezembro. Disponível em: < Geopauta (uesb.br)>. Acesso em: 05 nov. 2020.

COLARES, Gustavo Stolzenberg; SILVA, Fagner Pereira da; CELENTE, Gleison de Souza; RADKTE, Julia Fernanda; MACHADO, Ênio Leandro; Sistema integrado de tratamento de efluentes sanitários com reatores anaeróbicos sequenciais em batelada e WETLANDS construídos de fluxos alternados. Rebista Tecno-Lógica. Santa Cruz do Sul, v. 22, n. 1, p. 18-24, jan./jun. 2018. Disponível em: http://online.unisc.br/seer/index.php/tecnol ogica.>. Acesso em: 05 nov. 2020.

MORUZZI, Rodrigo Braga; Estimativa do lançamento de água pluvial no sistema de coleta e transporte de esgoto sanitário por meio de práticas de aproveitamento em residências unifamiliares. Eng Sanit Ambient.| v.21 n.1, jan/mar 2016, 85-94.

BERTOLINO, Murilo; KONDAGESKI, Jonas Heitor; WEINSCHUTZ, Regina; Água de chuva domiciliar no esgoto separador absoluto. Revista DAE. núm. 213, vol. 66, outubro a dezembro de 2018. SOUZA, Gisele Silva de; CECCONELLO, Samanta Tolentino; CENTENO, Luana Nunes; Redes ociosas: um estudo de caso 
sobre a percepção da população do bairro Laranjal quanto à obrigatoriedade da ligação dos ramais prediais à rede pública coletora de esgotos. Revista Thema. 2018, volume 15 . $\mathrm{N}^{\circ} 4$. Disponível em:

<https://doi.org/10.15536/thema.15.2018.1 499-1510.882 >. Acesso em: 05 nov. 2020.

RODRIGUES, Gustavo Paiva Weyne; FARIAS, Guilherme Marques; COSTA, Luís Henrique Magalhães; CASTRO, Marco Aurélio Holanda de; Otimização do traçado de redes coletoras de esgoto sanitário via algoritmo genético. Revista

DAE. São Paulo, v. 68, n 222, pp 164-177,
Ed. Esp. Mar 2020. Disponível em: <https://doi.org/10.36659/dae.2020.024>. Acesso em: 05 de nov. 2020.

ZSCHORNACK, Thiago; OLIVEIRA, Therezinha Maria Novais de; Avaliação do impacto da implantação do sistema de esgotamento sanitário na qualidade da água da Bacia Hidrográfica do Rio Cachoeira, em Joinville, Santa Catarina. Revista DAE. Núm. 212, vol. 66, Edição Especial 2018. Disponível em:

<DOI:10.4322/dae.2018.027>. Acesso em: 05 de nov. 2020. 


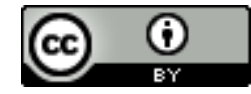

Esta obra está sob o direito de Licença Creative Commons Atribuição 4.0 Internacional.

\title{
A INFLUÊNCIA DA RELAÇÃO ENTRE SANEAMENTO BÁSICO E SAÚDE PÚBLICA NO COMBATE À DISSEMINAÇÃO DO COVID-19
}

\author{
Marcelo Lucas Alves ${ }^{1}$ \\ Maria Clara da Rocha dos Santos Silva ${ }^{2}$ \\ Maria Eduarda Melo Calado 3 \\ Matheus Henrique Alves da Silva ${ }^{4}$ \\ Nivea Tavares da Silva \\ Paulo Bruno Silva Santos 6
}

\section{RESUMO}

As questões relacionadas à saúde, higiene e meio ambiente envolvem grande parte da população mundial. No Brasil, a falta de acesso aos serviços básicos atinge principalmente os mais pobres, concentrados em favelas, periferias urbanas e áreas rurais. A falta ou ineficiência dos serviços de saúde tem agravado a saúde e a qualidade de vida das pessoas. Portanto, a falta de investimento neste setor tem um impacto negativo no sistema econômico devido ao saneamento básico e aos altos gastos com a prevenção e o tratamento da transmissão de doenças. Com base no texto supracitado o presente trabalho se propõe a avaliar por meio de uma revisão sistemática integrativa a relação entre saneamento básico e saúde pública no combate à disseminação do COVID-19. Analisaram-se os artigos publicados na base de dados da plataforma CAPES entre os anos de 2015 e 2020, sobre saneamento básico, saúde pública, esgotamento sanitário e covid19, adotando alguns critérios de inclusão e exclusão. A busca resultou em dez artigos de relevância para o contexto e a problemática proposta, que foram explorados e discutidos. Portanto, é de suma importância o investimento em saneamento básico acarretando assim menos gastos e superlotações na saúde pública, além de diminuir a disseminação de doenças de veiculação hídrica.

Palavras-chave: Esgotamento sanitário. Saúde Pública. SARS-CoV-2. Pandemia.

\footnotetext{
1 apolo273_my@hotmail.com

2 clara_rochha@outlook.com

3 eduardamelocallado@gmail.com

${ }^{4}$ henrique321santos@hotmail.com

5 niveatavares84@hotmail.com

${ }^{6}$ paulobruno1373@gmail.com
} 


\section{INTRODUÇÃO}

Após quase duas décadas de falta de regulamentação e ordenamento jurídico, foi aprovada a Lei 11.445 e estabelecidas as diretrizes nacionais para instalações de saneamento básico, que hoje é considerado um conjunto de ações de abastecimento de água (AA), esgotamento sanitário (ES), manejo de resíduos sólidos (MRS) e manejo das águas pluviais (MAP), bem como definição de outros conteúdos importantes (MENEZES, 2014).

Na gestão do sistema de saúde mundial de hoje, a pandemia COVID-19 é o foco da atenção contemporânea. Desde o surto no final de 2019, com a rápida propagação da epidemia em Hubei, China, essa nova síndrome respiratória se espalhou por todos os cantos do mundo a um ritmo alarmante (DA SILVEIRA, 2020).

A COVID-19 é uma doença infecciosa que tem como agente causador 0 coronavírus denominado SARS-CoV-2. Pesquisas científicas apontam que a disseminação do COVID-19 de pessoa para pessoa ocorre principalmente pela via respiratória. Porem recentemente foi encontrado o vírus nas fezes de indivíduos infectados, com ou sem sintomas (PÊGO, 2020).

Embora tal panorama tenha origem sanitária, ele também agrava os problemas sociais em diferentes ordens ao tangenciar problemas relacionados às condições de moradia, alimentação, trabalho, renda e acesso a bens de consumo. Portanto, o desafio que se apresenta vai além do setor saúde. Porém, no âmbito da gestão do sistema de saúde, o desafio é prioritário, exigindo a competência técnica e capacidade política de seus representantes e equipes para mitigar o impacto da pandemia em cada localidade (QUINTSLR, 2020).

A falta ou ineficiência dos serviços de saneamento tem agravado a saúde e a qualidade de vida das pessoas. Logo, é possível perceber que a falta de entrega neste setor gera um impacto extremamente negativo na economia. Este artigo tem como objetivo analisar até que nível a relação entre saneamento básico e saúde pública influencia no combate à disseminação do COVID-19. De modo que, torna-se necessário a atuação de políticas públicas que busquem expandir os serviços de saneamento, essencialmente para as localidades com situações mais precárias. 


\section{METODOLOGIA}

A metodologia adotada no presente trabalho trata-se de uma revisão sistemática integrativa que teve como base de buscas a plataforma de periódicos CAPES, utilizando-se os descritores saneamento básico, saúde pública, esgotamento sanitário e covid-19 conectados pelo conector booleano "And".

Para o escopo deste estudo, consideraramse como critérios de inclusão: Artigos publicados entre 2015 e 2020, que respondiam à pergunta norteadora e atendiam a temática estabelecida pelos descritores, em língua portuguesa. Foram excluídos artigos que não contemplam a temática. Criou-se um fichamento protocolar contemplando: títulos, ano, autor, palavras chave e tipo de pesquisa. O Quadro 1 demonstra como os descritores foram utilizados e a quantidade de estudos localizados na base de dados, assim como detalhamentos como o cadastro dos descritores nos bancos de terminologias, tema, objetivo, pergunta norteadora, entre outros. 
Quadro 1 - Detalhamento das etapas da Revisão Sistemática Integrativa.

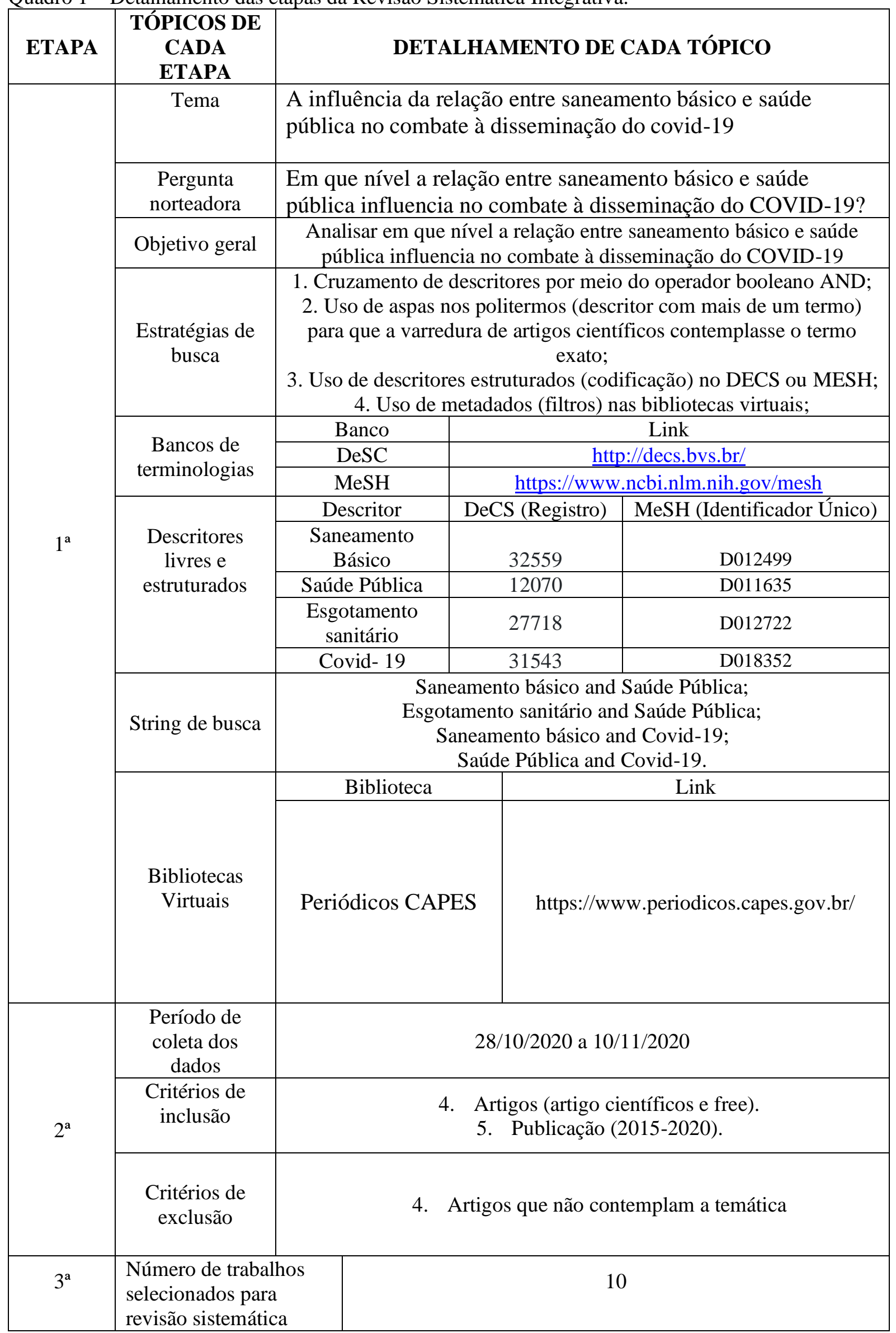




\begin{tabular}{|c|l|l|}
\hline & $\begin{array}{l}\text { integrativa a partir da } \\
\text { leitura dos agentes } \\
\text { indexadores das } \\
\text { publicações (tema, } \\
\text { descrição, ementa). }\end{array}$ & \\
\hline $4^{\mathrm{a}}$ & $\begin{array}{l}\text { Categorias obtidas com } \\
\text { a análise dos } \\
\text { documentos } \\
\text { investigados online } \\
\text { gratuitos e de livre } \\
\text { acesso }\end{array}$ \\
\hline $5^{\mathrm{a}}$ & $\begin{array}{l}\text { Análise, interpretação e } \\
\text { discussão dos } \\
\text { resultados }\end{array}$ & \\
\hline $6^{\mathrm{a}}$ & $\begin{array}{l}\text { Apresentação da } \\
\text { revisão em formato de } \\
\text { artigo, o qual } \\
\text { contemple propostas } \\
\text { para estudos futuros }\end{array}$ & \\
\hline
\end{tabular}

Fonte: elaborada pelos autores.

\section{RESULTADOS}

O detalhamento sobre as strings de busca utilizadas na base de dados do Periódico CAPES e os respectivos dados quantitativos sobre os resultados dos artigos nas buscas estão dispostos no Quadro 2. Dentro dessa perspectiva, a string com maior quantidade de artigos encontrados dentro da temática foi "Saneamento básico And Saúde pública", com o total de 691 trabalhos, sendo que, desses, apenas 4 selecionados para compor os resultados e discussão.

Quadro 2 - Corresponde ao total de documentos disponíveis na Plataforma obtidos por string de busca.

\begin{tabular}{|l|c|c|c|c|}
\hline \multicolumn{1}{|c|}{ String de busca } & $\begin{array}{c}\text { Bases de } \\
\text { dados }\end{array}$ & $\begin{array}{c}\text { Total de } \\
\text { publicações } \\
\text { sem o filtro }\end{array}$ & $\begin{array}{c}\text { Publicações } \\
\text { disponíveis após } \\
\text { aplicar os filtros }\end{array}$ & $\begin{array}{c}\text { Publicações } \\
\text { aproveitadas na } \\
\text { Revisão Sistemática } \\
\text { Integrativa }\end{array}$ \\
\hline $\begin{array}{l}\text { Saneamento Básico } \\
\text { And Saúde Pública }\end{array}$ & $\begin{array}{c}\text { Periódico } \\
\text { CAPES }\end{array}$ & 691 & 253 & 4 \\
\hline $\begin{array}{l}\text { Esgotamento } \\
\text { Sanitário And } \\
\text { Saúde Pública }\end{array}$ & $\begin{array}{c}\text { Periódico } \\
\text { CAPES }\end{array}$ & 180 & 87 & 2 \\
\hline $\begin{array}{l}\text { Saneamento básico } \\
\text { And Covid-19 }\end{array}$ & $\begin{array}{c}\text { Periódico } \\
\text { CAPES }\end{array}$ & 3 & 3 & 1 \\
\hline $\begin{array}{l}\text { Saúde Pública And } \\
\text { Covid-19 }\end{array}$ & $\begin{array}{c}\text { Periódico } \\
\text { CAPES }\end{array}$ & 128 & 102 & 3 \\
\hline
\end{tabular}

Fonte: elaborada pelos autores. 
O Quadro 3 trás o detalhamento dos 10 (dez) artigos selecionados após a aplicação dos critérios de inclusão e exclusão, assim como, avaliação técnica dos artigos. O Quadro mostra a autoria, o tema, o link e a data de publicação e a conclusão dos artigos.

Quadro 3- Descrição dos documentos (artigos) de acordo com os critérios de inclusão.

\begin{tabular}{|c|c|c|c|c|c|}
\hline $\mathbf{N}^{\mathbf{o}}$ & Autor(a) & Tema & $\begin{array}{c}\text { Link da } \\
\text { publicacão }\end{array}$ & $\begin{array}{c}\text { Data de } \\
\text { publicacão }\end{array}$ & Conclusão \\
\hline 1 & $\begin{array}{l}\text { Fernanda } \\
\text { Flores } \\
\text { Silva } \\
\text { Dos } \\
\text { Santos. }\end{array}$ & $\begin{array}{l}\mathrm{O} \\
\text { desenvolvimen } \\
\text { to do } \\
\text { saneamento } \\
\text { básico no } \\
\text { Brasil e as } \\
\text { consequências } \\
\text { para a saúde } \\
\text { pública }\end{array}$ & $\begin{array}{l}\text { https://bityli.co } \\
\text { m/cK3hp }\end{array}$ & 01/10/2018 & $\begin{array}{l}\text { Apesar do grande volume de } \\
\text { recursos públicos investidos } \\
\text { no setor de saneamento, a } \\
\text { situação do País demonstra } \\
\text { que há um grande atraso na } \\
\text { universalização destes } \\
\text { serviços, de modo que este já } \\
\text { devia ter sido atingido e estar } \\
\text { compatível com om o } \\
\text { desenvolvimento econômico } \\
\text { alcançado nos últimos anos. } \\
\text { O saneamento básico é um } \\
\text { direito de necessidade } \\
\text { imediata, pois, sua ausência } \\
\text { ou deficiência influencia } \\
\text { negativamente no meio } \\
\text { ambiente, na qualidade de } \\
\text { vida e saúde da população, } \\
\text { sendo inadmissível pensar a } \\
\text { existência de uma sociedade } \\
\text { em desenvolvimento sem esta } \\
\text { prestar serviços básicos em } \\
\text { quantidade e qualidade } \\
\text { suficiente, como o } \\
\text { saneamento [...] }\end{array}$ \\
\hline 2 & $\begin{array}{c}\text { Priscila } \\
\text { Neves } \\
\text { Silva }\end{array}$ & 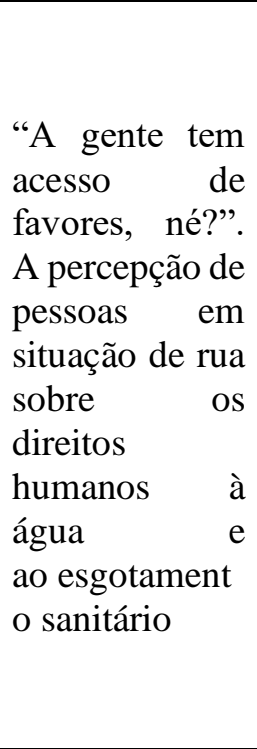 & $\begin{array}{l}\text { https://bityli.co } \\
\text { m/B0QSW }\end{array}$ & 01/03/2018 & $\begin{array}{l}\text { Observa-se que a população } \\
\text { em situação de rua sofre } \\
\text { diferentes tipos de violações } \\
\text { dos DHAES, assim como de } \\
\text { outros direitos, como o direito } \\
\text { à cidade, à moradia e à saúde. } \\
\text { A violação desses direitos } \\
\text { tem repercussões negativas } \\
\text { na vida econômica e social } \\
\text { desse grupo populacional, } \\
\text { aumentando a discriminação } \\
\text { e a exclusão. Assim, é } \\
\text { importante promover o } \\
\text { reconhecimento do acesso à } \\
\text { água e ao saneamento como } \\
\text { direito, por parte do Estado. } \\
\text { [...] }\end{array}$ \\
\hline
\end{tabular}




\begin{tabular}{|c|c|c|c|c|c|}
\hline 3 & $\begin{array}{c}\text { Luís } \\
\text { Paulo } \\
\text { Souza e } \\
\text { Souza }\end{array}$ & $\begin{array}{l}\text { Presença do } \\
\text { novo } \\
\text { coronavírus } \\
\text { (SARS-CoV- } \\
\text { 2) nos esgotos } \\
\text { sanitários: } \\
\text { apontamentos } \\
\text { para ações } \\
\text { complementar } \\
\text { es de vigilância } \\
\text { à saúde em } \\
\text { tempos de } \\
\text { pandemia }\end{array}$ & $\begin{array}{c}\text { https://bityli.co } \\
\text { m/tp5tc }\end{array}$ & $01 / 06 / 2020$ & $\begin{array}{l}\text { Apesar de, até o momento, } \\
\text { nenhuma pesquisa confirmar } \\
\text { a } \\
\text { transmissão da COVID-19 } \\
\text { pela via fecal-oral, os estudos } \\
\text { aqui apresentados sinalizam a } \\
\text { importância de incluir esta } \\
\text { temática na pauta de } \\
\text { discussões frente à pandemia. } \\
\text { No Brasil, mesmo com as } \\
\text { dificuldades relativas ao } \\
\text { saneamento, os esgotos } \\
\text { podem ser mais uma } \\
\text { ferramenta capaz de } \\
\text { contribuir nos esforços das } \\
\text { vigilâncias sanitária, } \\
\text { ambiental e epidemiológica. } \\
\text { Torna-se essencial que o } \\
\text { Estado amplie o sistema de } \\
\text { esgotamento sanitário para a } \\
\text { população, além de adotar } \\
\text { medidas que estimulem e } \\
\text { exijam das empresas } \\
\text { prestadoras dos serviços de } \\
\text { saneamento o alinhamento de } \\
\text { suas atuações, com a a } \\
\text { necessidade de que elas } \\
\text { tenham controle sobre os } \\
\text { sistemas, para que sejam } \\
\text { fornecidos dados de } \\
\text { qualidade e capazes de } \\
\text { orientar medidas preventivas } \\
\text { de contágio e mitigação dos } \\
\text { riscos de adoecimento. [...] }\end{array}$ \\
\hline 4 & $\begin{array}{l}\text { Davi } \\
\text { Santiago } \\
\text { Aquino }\end{array}$ & $\begin{array}{l}\text { Influência do } \\
\text { acesso a } \\
\text { saneamento } \\
\text { básico na } \\
\text { incidência e na } \\
\text { mortalidade } \\
\text { por COVID- } \\
\text { 19: análise de } \\
\text { regressão } \\
\text { linear múltipla } \\
\text { nos estados } \\
\text { brasileiros. }\end{array}$ & $\begin{array}{l}\text { https://bityli.co } \\
\text { m/53OyN }\end{array}$ & $01 / 10 / 2020$ & $\begin{array}{l}\text { Ao se analisarem os dados } \\
\text { mais recentes de acesso das } \\
\text { populações das unidades } \\
\text { federativas do Brasil aos } \\
\text { serviços de abastecimento de } \\
\text { água e de esgotamento } \\
\text { sanitário, bem como as taxas } \\
\text { de incidência e de } \\
\text { mortalidade por COVID-19 } \\
\text { registradas nos estados e no } \\
\text { Distrito Federal } 90 \text { dias após } \\
\text { a confirmação do primeiro } \\
\text { caso da doença no país, } \\
\text { verificou-se a existência de } \\
\text { influência linear } \\
\text { estatisticamente significativa } \\
\text { das variáveis relativas a } \\
\text { saneamento básico na } \\
\text { incidência acumulada, de } \\
\text { forma que quanto maior o }\end{array}$ \\
\hline
\end{tabular}




\begin{tabular}{|c|c|c|c|c|c|}
\hline & & & & & $\begin{array}{lcr}\text { acesso aos serviços de } & \text { de } \\
\text { saneamento, } & \text { menor } \\
\text { incidência de COVID-19. [...] }\end{array}$ \\
\hline 5 & $\begin{array}{l}\text { Luis } \\
\text { Arthur } \\
\text { Brasil } \\
\text { Gadelha } \\
\text { Farias }\end{array}$ & $\begin{array}{l}\text { O papel da } \\
\text { atenção } \\
\text { primária no } \\
\text { combate ao } \\
\text { Covid-19: } \\
\text { impacto na } \\
\text { saúde pública e } \\
\text { perspectivas } \\
\text { futuras }\end{array}$ & $\begin{array}{c}\text { https://bityli.co } \\
\text { m/tIw3G }\end{array}$ & $01 / 05 / 2020$ & $\begin{array}{l}\text { Desta forma, a APS deve ser } \\
\text { a porta de entrada deste } \\
\text { paciente no sistema de saúde. } \\
\text { Uma vez que essa atenção } \\
\text { primária esteja bem equipada } \\
\text { e integrada terá papel } \\
\text { fundamental no controle e na } \\
\text { redução de danos causados } \\
\text { pela pandemia pelo Covid-19. } \\
\text { Neste momento, a melhor } \\
\text { ferramenta de controle } \\
\text { existente para o Covid-19 é a } \\
\text { prevenção e não existe } \\
\text { melhor lugar para } \\
\text { desenvolvê-la do que na APS. } \\
\text { Logo, é necessária a garantia } \\
\text { do bom funcionamento da } \\
\text { APS por meio da valorização } \\
\text { da ESF, o que envolve um } \\
\text { melhor fortalecimento deste } \\
\text { nível de atenção, incluindo a } \\
\text { garantia de condições dignas } \\
\text { de trabalho e de assistência. } \\
\text { Importante destacar que, } \\
\text { dentre essas condições, é } \\
\text { fundamental o provimento de } \\
\text { EPI's adequados e em } \\
\text { quantidade necessária para } \\
\text { que os profissionais possam } \\
\text { ter segurança em sua atuação } \\
\text { e, consequentemente, } \\
\text { protegerem seus pacientes. }\end{array}$ \\
\hline 6 & $\begin{array}{l}\text { Daniela } \\
\text { Borcezi }\end{array}$ & $\begin{array}{l}\text { VULNERÁV } \\
\text { EIS }\end{array}$ & $\begin{array}{c}\text { https://bityli.co } \\
\text { m/QBzTs }\end{array}$ & $01 / 09 / 2020$ & $\begin{array}{l}\text { [...] Ao contrário disso, as } \\
\text { reportagensVulnerabilidades } \\
\text { que aproximas as Favelas } \\
\text { contra o vírus, nos revelam } \\
\text { narrativas pautadas no } \\
\text { "homem comum" e na } \\
\text { ausência de políticas públicas } \\
\text { sociais em meio a pandemia } \\
\text { da covid-19. [...] }\end{array}$ \\
\hline 7 & $\begin{array}{l}\text { Michael } \\
\text { Ferreira } \\
\text { Machado }\end{array}$ & $\begin{array}{l}\text { Vigilância } \\
\text { em Saúde em } \\
\text { tempos de } \\
\text { pandemia: } \\
\text { análise dos } \\
\text { planos de } \\
\text { contingência }\end{array}$ & $\begin{array}{c}\text { https://bityli.co } \\
\text { m/9hhRc }\end{array}$ & $01 / 06 / 2020$ & $\begin{array}{l}\text { A pandemia da COVID-19 } \\
\text { trouxe uma série de desafios } \\
\text { ao SUS na produção de } \\
\text { respostas articuladas e } \\
\text { efetivas para a proteção da } \\
\text { população brasileira. Neste } \\
\text { âmbito, os aspectos político- } \\
\text { institucionais e de articulação }\end{array}$ \\
\hline
\end{tabular}




\begin{tabular}{|c|c|c|c|c|c|}
\hline & & $\begin{array}{l}\text { dos estados } \\
\text { do Nordeste }\end{array}$ & & & $\begin{array}{l}\text { da Vigilância em Saúde são } \\
\text { fundamentais. A atuação } \\
\text { integrada e compartilhada da } \\
\text { Vigilância em Saúde nos } \\
\text { diversos níveis de governo } \\
\text { está prevista no arcabouço } \\
\text { normativo do SUS. No } \\
\text { contexto nordestino, além da } \\
\text { heterogeneidade dos } \\
\text { municípios, há que considerar } \\
\text { ainda fragilidades } \\
\text { institucionais na gestão local } \\
\text { do sistema de saúde, visto que } \\
\text { a região Nordeste concentra } \\
63,4 \% \text { de municípios do } \\
\text { grupo de pequeno porte do } \\
\text { país. [...] }\end{array}$ \\
\hline 8 & $\begin{array}{l}\text { Tatiana } \\
\text { Santana } \\
\text { Timóteo } \\
\text { Pereira }\end{array}$ & $\begin{array}{l}\text { Planos } \\
\text { municipais de } \\
\text { saneamento } \\
\text { básico: } \\
\text { avaliação de } 18 \\
\text { casos } \\
\text { brasileiros }\end{array}$ & $\begin{array}{l}\text { https://bityli.co } \\
\text { m/Z2Uh1 }\end{array}$ & $01 / 09 / 2015$ & $\begin{array}{l}\text { Alguns dos planos avaliados } \\
\text { destacaram-se por terem } \\
\text { atendido de forma geral à } \\
\text { maioria das categorias: } \\
\text { Alagoinhas, Morada Nova, } \\
\text { Ariquemes e Ouro Branco. } \\
\text { Também foram esses os que } \\
\text { tiveram os processos mais } \\
\text { participativos e que adotaram } \\
\text { algumas técnicas de } \\
\text { planejamento. Tal } \\
\text { constatação leva a reforçar a } \\
\text { hipótese de que quanto mais } \\
\text { participativo o processo mais } \\
\text { informações se agregam ao } \\
\text { plano, possibilitando a } \\
\text { incorporação das demandas, e } \\
\text { maior a possibilidade de ser } \\
\text { implementado e interferir na } \\
\text { qualidade do saneamento do } \\
\text { município. Esses quatro } \\
\text { planos foram elaborados para } \\
\text { os quatro componentes do } \\
\text { saneamento e também foram } \\
\text { aprovados por lei. [...] }\end{array}$ \\
\hline 9 & $\begin{array}{l}\text { Ana } \\
\text { Cristina } \\
\text { A. de } \\
\text { Souza }\end{array}$ & $\begin{array}{l}\text { Política de } \\
\text { saneamento } \\
\text { básico no } \\
\text { Brasil: } \\
\text { discussão de } \\
\text { uma trajetória }\end{array}$ & $\begin{array}{c}\text { https://bityli.co } \\
\text { m/9vwTz }\end{array}$ & $01 / 09 / 2016$ & $\begin{array}{l}\text { Este estudo partiu do } \\
\text { princípio de que a política } \\
\text { pública de saneamento é, } \\
\text { acima de tudo, afetada por } \\
\text { atores, interesses e } \\
\text { instituições que permitiriam } \\
\text { explicar o baixo desempenho } \\
\text { observado nas últimas } \\
\text { décadas. Sem a intenção de } \\
\text { esgotar o debate, o trabalho } \\
\text { tentou identificar os } \\
\text { principais atores e as }\end{array}$ \\
\hline
\end{tabular}




\begin{tabular}{|c|c|c|c|c|c|}
\hline & & & & & $\begin{array}{l}\text { conjunturas críticas que } \\
\text { configuraram a arena } \\
\text { decisória desse setor no } \\
\text { Brasil. A utilização da } \\
\text { categoria dependência de } \\
\text { trajetória } \\
\text { identificar a matriz histórica } \\
\text { da estrutura e da inércia da } \\
\text { configuração política recente } \\
\text { do setor de saneamento no } \\
\text { país, iniciada a partir da } \\
\text { imposição do Planasa em } \\
\text { 1971. O arranjo instituído } \\
\text { pelo Planasa produziu } \\
\text { retornos positivos de ordem } \\
\text { política e econômica que } \\
\text { reforçaram uma trajetória } \\
\text { essencialmente marcada pela } \\
\text { dominância dos grupos } \\
\text { estadualistas e de suas } \\
\text { instituições no setor. [...] }\end{array}$ \\
\hline 10 & $\begin{array}{l}\text { Irene } \\
\text { Patrícia } \\
\text { Nohara }\end{array}$ & $\begin{array}{l}\text { Perspectivas } \\
\text { da gestão } \\
\text { do saneament } \\
\text { o básico no } \\
\text { Brasil: } \\
\text { prestação } \\
\text { indireta e } \\
\text { deficiências } \\
\text { setoriais }\end{array}$ & $\begin{array}{c}\text { https://bityli.co } \\
\text { m/v3MF6 }\end{array}$ & $01 / 07 / 2018$ & $\begin{array}{l}\text { Por meio do presente artigo, } \\
\text { buscou-se apresentar os } \\
\text { acertos e os desacertos da } \\
\text { atual política pública de } \\
\text { saneamento básico no Brasil, } \\
\text { notadamente ante o cotejo da } \\
\text { perspectiva histórica de } \\
\text { prestação do serviço público e } \\
\text { a transformação dos modelos } \\
\text { de gestão administrativa. } \\
\text { Demonstrou-se que o Brasil } \\
\text { é, por determinação } \\
\text { constitucional, um Estado } \\
\text { Democrático e Social de } \\
\text { Direito, que deve equalizar o } \\
\text { sistema capitalista e a } \\
\text { garantia dos direitos } \\
\text { fundamentais à cidadania. } \\
\text { Dentre os direitos } \\
\text { fundamentais, os direitos } \\
\text { sociais, principalmente, têm } \\
\text { por objeto as políticas } \\
\text { públicas, que se caracterizam } \\
\text { por um conjunto de } \\
\text { programas estatais voltados a } \\
\text { uma finalidade } \\
\text { constitucionalmente pré- } \\
\text { determinada. [...] }\end{array}$ \\
\hline
\end{tabular}

Fonte: elaborada pelos autores.

Após o preenchimento do Quadro 3, utilizam-se as conclusões dos artigos para a realização da análise por meio da frequência de palavras, que originou a nuvem de palavras 
(Figura 1). Para a criação da nuvem foi utilizada a Plataforma online WordArt. Esta ferramenta agrupa e organiza graficamente as palavras-chave evidenciando-as as mais frequentes e que, portanto, deu subsídio para confecção das categorias de discussões.

Por meio da Figura 1, foi possível observar que as palavras em evidência na nuvem pertencem às categorias desenvolvidas a partir da análise de conteúdo de Bardin. Todas as categorias derivam da sua frequência (Tabela 1), que diz respeito ao seu quadro referencial. Em consonância ao objetivo deste trabalho, optou-se por descrever as palavras que apresentaram frequência total no texto e, a partir de seus sentidos nos campos textuais, tinham maior relevância para as representações sociais sobre a influência da relação entre saneamento básico e saúde pública no combate à disseminação do covid-19, como apresentado na Figura 1.

Figura 1 - Nuvem de palavras criada com base nas conclusões dos trabalhos listados no Quadro 3. 


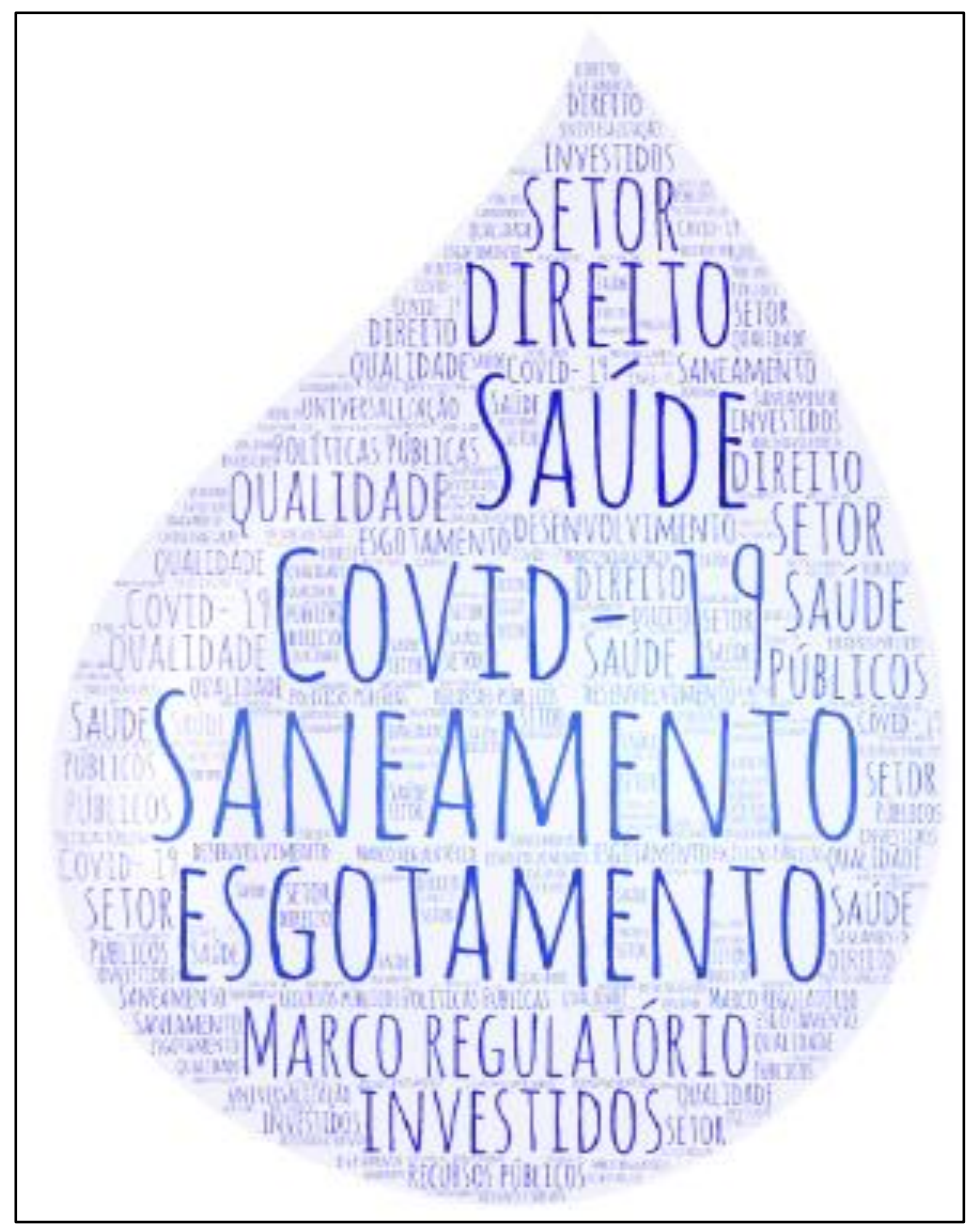

Fonte: elaborada pelos autores.

Tabela 1: Frequência das palavras presentes nos textos publicados na Plataforma Periódico CAPES

\begin{tabular}{l|c|c}
\hline \multicolumn{1}{c|}{ PALAVRAS } & FREQUÊNCIA & CATEGORIAS \\
\hline Saneamento & 20 & 3 \\
\hline Esgotamento & 18 & 2 \\
\hline Covid-19 & 14 & 3 \\
\hline Saúde & 10 & 1 \\
\hline Marco Regulatório & 8 & 3 \\
\hline Direito & 8 & 2 \\
\hline Investidos & 8 & 3 \\
\hline Qualidade & 8 & 3 \\
\hline Setor & 8 & 2 \\
\hline Políticas Públicas & 7 & 3 \\
\hline Desenvolvimento & 7 & 3 \\
\hline Recursos Públicos & 6 & 2 \\
\hline Universalização & 3 & \\
\hline
\end{tabular}

Fonte: elaborada pelos autores. 


\section{DISCUSSÕES}

As categorias de discussão abaixo, oriundas da análise das frequências das palavras (Tabela 1) e da evidência dessas diante da nuvem (Figura 1), assim como, da análise técnica das temáticas abordadas nos artigos selecionados e dispostos no Quadro 3, deram subsídio para discussões pertinentes a temática central do artigo. Abaixo seguem as 3 (três) categorias elaboradas.

\section{Histórico do Saneamento Básico no Brasil}

Após um longo período de debates, a Lei $n^{\circ} 11.445 / 2007$, que estabelece diretrizes nacionais para o saneamento básico no Brasil, entrou oficialmente em vigor em 22/02/2007, regulando um setor que apesar de ser de suma importância permanecia sem regulação específica. Dentre os diversos setores da infraestrutura, as instalações de saneamento básico apresentam características que ajudam a explicar a demora no estabelecimento de um marco regulatório nas áreas jurídica e econômica. Porém, para entendê-los, é interessante considerar a história do Brasil na prestação de serviços básicos de saúde (PEREIRA 2015).

$\mathrm{Na}$ década de 1930, quando foram criados os Ministérios da educação e da saúde pública pelo constituinte da época, o serviço de saneamento era prestado diretamente pelos municípios. Na década de 40 foi criada a fundação SESP e houve várias críticas ao modelo de gestão pela administração direta dos Municípios muito em função de uma política tarifária que era deficitária na época e como solução foi criados na década de 1950 os sites sistemas autônomos de água e esgotos na forma de Autarquia Municipal sobre responsabilidade Nacional do SESP e controlada pelos municípios. Já na década de 1960, a SUDENE e posteriormente BNH começaram a financiar um novo modelo de gestão com a criação das Companhias Estaduais de saneamento básico Segundo Galvão Júnior (2009), a configuração atual da secretaria teve início na década de 1970, quando o governo federal formulou o Plano Nacional de Saneamento Básico PLANASA. Antes disso, os municípios forneciam serviços separadamente. No entanto, os benefícios proporcionados pelo PLANASA estimularam a constituição das Empresas Nacionais de Saneamento Básico (CESB), que passaram a prestar serviços de saneamento básico em grande parte do país (SANTOS, 2018).

No entanto, a Constituição Federal de 1988 questionou a real titularidade dos serviços básicos de saúde ao conceder aos municípios a capacidade de organizar e prestar serviços públicos de interesse local 
diretamente ou sob regime de concessão ou licenciamento. Esse dispositivo constitucional tem gerado discussões entre municípios e estados sobre a titularidade e a capacidade de prestação dos serviços básicos de saúde, a discussão tornou-se um dos maiores obstáculos para a aprovação de qualquer projeto de lei que se converta em marco regulatório do setor (SILVA, 2018).

Em 2003, no governo de Lula, iniciouse um intenso processo de reestruturação institucional do setor que se materializou na criação do Ministério das Cidades, que visa integrar políticas relacionadas ao desenvolvimento da cidade. Ele é responsável por propor um novo marco regulatório de saúde e apresentar um projeto de lei à Câmara dos Representantes para votação. Este projeto propõe inovações importantes para a indústria. Entre eles, o novo instrumento da gestão, subordinada a uma agência reguladora, estabelecendo uma agência de controle universitário e fundos federais. É possível perceber que a política pública de saneamento é, acima de tudo, afetada por atores, interesses e instituições que permitiriam explicar o baixo desempenho observado nas últimas décadas (SOUZA, 2016).

"Em 2020, o Comitê das Nações Unidas sobre os Direitos Econômicos, Sociais e Culturais elaborou o Comentário Geral n ${ }^{\circ} 15$ sobre o direito humano à água.
Segundo este comentário o direito à água se enquadra no direito a uma vida com qualidade e está intimamente relacionado com o direito à saúde, alimentação e moradia digna, previstos no Tratado Internacional sobre Direitos Econômicos, Sociais e Culturais. O comentário também estabelece que o acesso ao esgotamento sanitário é essencial para que o direito à água seja atingido." (SILVA, 2018).

\section{Relação do COVID-19 com o Saneamento e as Desigualdades Sociais}

A COVID-19 é uma doença infecciosa que faz com que o coronavírus SARS-CoV2 se torne seu patógeno. Pesquisas científicas apontam que a disseminação do COVID-19 de pessoa para pessoa ocorre principalmente pela via respiratória, gotículas emitidas quando a pessoa infectada tosse ou espirra e pessoas saudáveis entram em contato com superfícies e objetos contaminados. Dependendo do material e / ou composição da superfície, pode permanecer por um período de tempo (SOUZA, 2020).

Porém, nos últimos meses, alguns estudos nacionais e internacionais foram publicados, cujos resultados mostram que o material genético do novo coronavírus está presente nas fezes, amostras de urina e de esgoto sanitário de pessoas infectadas (com ou sem sintomas). Portanto, esses estudos destacam os novos desafios que os países precisam reconhecer e enfrentar (MACHADO, 2020). 
Embora a OMS (Organização Mundial da Saúde) não tenha declarado que a via fecal-oral não é uma das principais formas de disseminação da COVID-19, o princípio da precaução ainda deve ser utilizado para discutir a possibilidade de que essa via esteja na pior pandemia deste século. Quanto ao princípio da precaução, uma vez que as consequências ou reações de certas ações não são totalmente claras no ambiente, espaço e tempo, devem ser tomadas as medidas necessárias para evitar danos (riscos) futuros ao ambiente e à saúde. Portanto, será importante realizar ações de monitoramento dos sistemas de esgotamento sanitário, principalmente em países onde os casos estão aumentando rapidamente, como o Brasil (SOUZA, 2020).

Na periferia, o conflito no combate ao vírus se manifesta nas políticas de moradia ineficientes dos moradores de rua, segurança alimentar e problemas de saneamento básico, que afetam também os moradores do entorno, que carecem diariamente de água.

Em entrevista para Borezzi (2020), Gisele Martins, jornalista e moradora do Morro da Maré falou que:

"[...] Como garantir medidas de higiene, como lavar as mãos a cada duas horas, se muitas favelas não tem água? [...] E se falta dinheiro para alimentação, como comprar álcool em gel ou álcool 70\%, quando se sabe que, em tempos de pandemia uma embalagem de produto chega a ser vendido por $\mathrm{R} \$ 15$ ?"

Débora Noal, psicóloga sanitarista diz que:

\begin{abstract}
"Lidar com as desigualdades é o maior desafio da pandemia [...] enquanto para uma parcela da sociedade a preocupação é com o crescimento da curva de contágio pelo vírus, as pessoas que vivem na rua se preocupa muito mais com a sobrevivência no presente."
\end{abstract}

No Brasil, os gestores federais, estaduais e municipais podem cogitar o monitoramento de esgoto, pois a coleta de esgoto é um serviço existente no país. Porém, mesmo que o país tenha o "Plano Nacional de Saúde" (PLANSAB), deve-se estar atento às limitações de todos os municípios, regiões e regiões em termos de cobertura ideal, que se refere ao processo de universalização desses serviços. De acordo com o Sistema Nacional de Informações sobre Saneamento (SNIS), nas áreas urbanas do Brasil, especialmente na região Sudeste, o percentual médio de serviços prestados por redes coletoras de esgoto é de $60,9 \%$ e a média é de $83,7 \%$. Em relação ao tratamento de esgoto, segundo observações, o índice médio do país é estimado em $46,3 \%$ do esgoto e $74,5 \%$ do coletado (MOHARA, 2018). 
Porém, é fundamental que o Estado amplie o sistema de tratamento de esgoto, inclusive o direito à água de qualidade, e garanta o direito da população a melhores condições de vida, o que afeta diretamente a saúde. Vale lembrar que, para cada $\mathrm{R} \$$ 1,00 investido em saneamento, pode-se economizar $\mathrm{R} \$ 4,00$. Portanto, a consideração do monitoramento do sistema de esgoto contempla também ações de saúde coletiva, avaliando as peculiaridades do território e sua dinâmica populacional e, ao mesmo tempo, considerando o controle social como instrumento de garantia do saneamento e do direito à água (SOUZA, 2020).

\section{Relação entre Saúde Pública e Saneamento Básico}

Para Santos (2018) o saneamento ambiental é compreendido como um conjunto de ações para promover e garantir o bem-estar e a segurança da população e a geração de ruído por meio de rede de tratamento de esgoto, abastecimento de água, coleta e disposição final de resíduos, drenagem e controle da poluição atmosférica. E ainda afirma que:

"Além de consubstanciar melhorias no quadro sanitário e de saúde da população, condições adequadas de saneamento contribuem para a redução de prejuízos econômicos nos cofres públicos brasileiros que ocorrem devido à destinação de recursos para o combate de doenças evitáveis, gerados por doenças infecciosas, parasitárias e transmitidos principalmente por veiculação hídrica".

A falta ou falta de instalações de saneamento básico pode ter um impacto negativo na saúde das pessoas. No Brasil, a gestão, a sistematização e a disponibilização das informações relacionadas ao saneamento básico ambiental são realizadas pelo Sistema Nacional de Informações sobre Saneamento (SNIS), que é vinculado à Secretaria Nacional de Saneamento do Ministério do Desenvolvimento Regional e ele próprio um banco. Dados sobre os quatro componentes do saneamento básico em nível municipal, estadual e nacional, a saber: abastecimento de água, esgoto doméstico, gestão e drenagem de resíduos sólidos urbanos e gestão de águas pluviais urbanas (AQUINO, 2020).

De acordo com o último levantamento do SNIS e dados de 2018, estima-se que $16,38 \%$ da população brasileira média não pode usar o sistema público de abastecimento de água. Principalmente no Norte, a proporção é de 42,90\%. Quanto à proporção da população sem acesso à rede pública de coleta de esgoto (inclusive uso de rede de tratamento de esgoto), a média nacional é de 46,85\% (SNIS, 2020).

Existe uma relação extremamente estreita e estreita entre saúde e saúde 
pública. É preciso ressaltar que a saúde é a base de todo o sistema de saúde de um país. A saúde pública está intimamente relacionada às instalações de saneamento. $\mathrm{O}$ aumento das doenças infecciosas e infecciosas é diretamente proporcional à falta de instalações sanitárias e vice-versa. A ocorrência de doenças infecciosas que levam à redução da produtividade, aumento dos custos e aumento das despesas médicas está totalmente relacionada à existência de saneamento básico (FARIAS, 2020).

Se for feito mais investimentos em saúde, as pessoas vão poder fazer um trabalho de saúde com mais saúde, vão ter mais poder, e com essa doença vão diminuir

\section{CONCLUSÕES}

É possível perceber que a falta de saneamento básico nas regiões mais pobres, ocasiona o aumento da COVID-19 nessas áreas, fazendo com que os gastos dos cofres públicos aumentem com o tratamento de mais pessoas contaminadas.

Neste contexto foi demonstrado que os locais mais carentes do território brasileiro são as partes periféricas, no qual sofrem com a falta de esgotamento sanitário, tornando assim mais vulneráveis para a disseminação de doenças.

Como o vazio na definição da titularidade da Lei $\mathrm{n}^{\circ} 11.445$ prejudica as faltas e faltas. A prevenção é mais econômica e o trabalho mais significativo, pois além de deixar dinheiro para outros investimentos, também pode permitir que pessoas mais saudáveis tenham melhor qualidade de vida (MOHARA, 2018).

Portanto, penso novamente que as instalações de saneamento básico são a plataforma básica e essencial para o desenvolvimento do país. Se você não investe em saneamento básico, não faz sentido ter um país rico com alta produção agrícola e industrial. Devido à falta de saneamento básico, todo o dinheiro e lucros que o país ganhou com as exportações e produção, são perdidos (AQUINO, 2020).

diretamente a população das regiões mais carentes onde as verbas públicas não são diretamente direcionadas para o saneamento básico, a constituição de 88 informa que compete aos municípios organizar e prestar os serviços públicos de interesse local.

Por fim, identificou-se que é necessária a atuação de políticas públicas que buscam expandir os serviços de saneamento, essencialmente para as localidades com situações mais precárias, para assim evitar a disseminação da COVID-19 e de outras doenças de veiculação hídrica. 


\section{REFERÊNCIAS}

AQUINO, Davi Santiago. Influência do acesso a saneamento básico na incidência e na mortalidade por COVID-19: análise de regressão linear múltipla nos estados brasileiros. Disponível em: <https://bityli.com/530yN >. Acesso em: 01/11/2020.

BORCEZI, Daniela. Vulneráveis.

Disponível em:

<https://bityli.com/QBzTs>. Acesso em: 28/10/2020.

DA SILVEIRA, Lucia Teresa Côrtes; DE OLIVEIRA, Alexandre Barbosa. Desafios e estratégias para a organização do setor saúde frente à pandemia de COVID19. Research, Society and Development, v. 9, n. 8, p. e543985987-e543985987, 2020 .

FARIAS, Luis Arthur Brasil Gadelha; COLARES, Matheus Pessoa; et.al. O papel da atenção primária no combate ao Covid-19: impacto na saúde pública e perspectivas futuras. Disponível em: < https://bityli.com/tIw3G>. Acesso em: 01/11/2020.

MACHADO, Michael Ferreira; QUIRÍNIO, Túlio Romério Lopes; Et.al. Vigilância em Saúde em tempos de pandemia: análise dos planos de contingência dos estados do Nordeste. Disponível em: < https://bityli.com/9hhRc>. Acesso em: 28/10/2020.

MENEZES, Paulo Renato. A Lei 11.445: o novo marco regulatório do saneamento no Brasil e seu impacto nas empresas públicas de água e esgoto: um estudo de caso. 2014.

NOHARA, Irene Patrícia; POSTAL, Júnior Jairo. Perspectivas da gestão do saneamento básico no Brasil: prestação indireta e deficiências setoriais.
Disponível em: < https://bityli.com/v3MF6>. Acesso em: 28/10/2020.

PÊGO, Bolívar et al. Pandemia e fronteiras brasileiras: análise da evolução da Covid-19 e proposições. 2020.

PEREIRA, Tatiana Santana Timóteo; HELLER, Léo. Planos municipais de saneamento básico: avaliação de 18 casos brasileiros. Disponível em: < https://bityli.com/Z2Uh1>. Acesso em: 02/11/2020.

QUINTSLR ${ }^{1}$, Suyá; BRITTO, Ana Lúcia; DIAS, Mariana. Coronavírus: reflexões acerca da pandemia global e sua relação com o direito à água e ao esgotamento sanitário. Observatório das metrópoles, 2020.

SANTOS, Fernanda Flores Silva dos; FILHO, José Daltro; et.al. O desenvolvimento do saneamento básico no Brasil e as consequências para a saúde pública. Disponível em: $<$ https://bityli.com/cK3hp $>$. Acesso em: 28/10/2010.

SILVA, Priscila Neves; MARTINS, Giselle Isabele; et. al. "A gente tem acesso de favores, né?". A percepção de pessoas em situação de rua sobre os direitos humanos à água e ao esgotamento sanitário. Disponível em: < https://bityli.com/B0QSW>. Acesso em: 01/11/2020.

SNIS, Sistema Nacional de Informações sobre Saneamento. Painel de informações sobre saneamento. 2020. Disponível em: $<$ http://www.snis.gov.br/painel-

informacoessaneamento-brasil/web/>. Acesso em: 09/11/2020.

SOUSA, Ana Cristina A. de; COSTA, Nilson do Rosário. Política de saneamento básico no Brasil: discussão de uma 
trajetória. História, Ciências, Saúde Manguinhos, Rio de Janeiro, v.23, n.3, jul.set. 2016, p.615-634.

SOUZA, Luís Paulo Souza e; SOARES, Alexandra Fátima Saraiva; et. al. Presença do novo coronavírus (SARS-CoV-2) nos esgotos sanitários: apontamentos para ações complementares de vigilância à saúde em tempos de pandemia. Disponível em: <https://bityli.com/tp5tc $>$. Acesso em: 02/11/2020. 


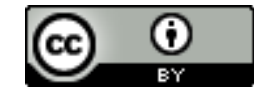

Esta obra está sob o direito de Licença Creative Commons Atribuição 4.0 Internacional.

\title{
OTIMIZAÇÃO EM REDES DE DISTRIBUIÇÃO HIDRÁULICAS
}

\author{
Ana Gabrielly Morais Silva ${ }^{1}$ \\ Andreza Leticia da Silva Santos Torres ${ }^{2}$ \\ Gilvan de Souza Ramos ${ }^{3}$ \\ João Vinícius Bezerra Lima ${ }^{4}$ \\ Michell Araújo de Souza ${ }^{5}$ \\ Rafaela Ribeiro de Oliveira ${ }^{6}$
}

\section{RESUMO}

O objetivo desse artigo foi realizar uma pesquisa bibliográfica com o intuito de demostrar, através de comparação de dados, a importância da elaboração de projetos de redes de distribuição de água de forma geral buscando otimização dos recursos hídricos, boa relação custo benefício e que estejam de acordo com as normatizações técnicas vigentes. A perda de carga em tubulações hidráulicas é uma importante variável para o dimensionamento de sistemas de transportes otimizados, assim, se torna obrigatório o estudo dessa variável no dimensionamento de redes de distribuição de abastecimento de águas. O presente trabalho está pautado na seguinte pergunta norteadora: quais as principais considerações, elencadas por diferentes autores, relacionadas a redução das perdas de carga em redes de distribuição de abastecimento na busca de otimização e da melhor relação custo benefício na sua implantação e operação? Foram buscados artigos científicos produzidos nos últimos cinco anos relacionados a temática na biblioteca Periódicos Capes utilizando uma forma estruturada de busca por meio de uma revisão sistemática integrativa. A análise dos artigos selecionados permitiu a criação de categorias que subsidiaram discussão dos principais pontos a serem considerados nos projetos redes de distribuição de abastecimento na busca de otimização. Conclui-se que, no projeto de dimensionamento hidrossanitário é fundamental o cômputo detalhado das perdas de carga distribuídas e localizadas, assim como, a adequação de todos os parâmetros hidráulicos para que não haja sub ou superdimensionamento no sistema e, que isso, não venha ocasionar problemas na relação custo benefício nem problemas futuros ao projeto.

Palavras-chave: Instalações prediais. Abastecimento. Dimensionamento.

\footnotetext{
1 anagabyms@hotmail.com

2 andrezals20@gmail.com

3 gil-ramos@outlook.com

4 joaovinicius1915@hotmail.com

5 miche10288@hotmail.com

${ }^{6}$ rafaelaribeiro.oliv@gmail.com
} 


\section{INTRODUÇÃO}

As perdas de cargas são comuns nas redes de distribuição de abastecimento (RDA), devido a vários possíveis meios que causam a variação de pressão e diâmetro interno nos tubos, além da rugosidade que influencia diretamente no fator de atrito entre o fluido e a tubulação.

A otimização das RDA de um determinado local se constitui como ferramentas de redução das perdas de cargas e adequação de parâmetros hidráulicos como subsídio para o dimensionamento de redes de distribuição de abastecimento (MORAIS, CAVALCANTE e ALMEIDA, 2010; SILVA et al., 2020). Os mesmos autores ressaltam que a utilização dessa ferramenta é fundamental para as cidades em desenvolvimento, haja vista que essas, necessitam a todo momento de ampliações das redes. A flexibilidade do projeto é um importante parâmetro a ser considerado no projeto de concepção de redes de distribuição de abastecimento (SILVA, 2016).

Os sistemas de abastecimento de águas - SAA, em sua totalidade, devem garantir as suas economias três características fundamentais, a saber, quantidade de água conforme a demanda de projeto, padrões de potabilidade para atividade que foi projetado e regularidade de abastecimento (BRASIL, 2017).

Segundo Silva et al. (2020) e Pinnto et al. (2017) a utilização de softwares e aplicativos facilitam o dimensionamento e proporcionam a otimização das RDA, balanceando o custo da implantação da tubulação e o tempo de vida útil dos materiais empregados.

Segundo os mesmos autores, esse procedimento é de suma importância e a combinação ótima de diâmetros para atender as especificações de abastecimento que satisfaçam o público familiar, comercial e industrial da cidade do projeto em questão, as insatisfações dos consumidores serão mínimas e respondidas com mais rapidez, pois será mais fácil detectar as fontes dos problemas. Os principais pontos a serem observados ao fazer a otimização da RDA (rede de distribuição de água) são: satisfação da população, impactos ambientais e custos de implantação e operacionais.

O dimensionamento de um SAA deve ser realizado com um alcance que contemple a projeção populacional, ou seja, a demanda de consumo, e para que seu funcionamento seja pleno em termos técnicos, evitando assim, os reparos exagerados. 
O presente trabalho está pautado na seguinte pergunta norteadora: quais as principais considerações, elencadas por diferentes autores, relacionadas a redução das perdas de carga em redes de distribuição de abastecimento na busca de otimização e da melhor relação custo benefício na sua implantação e operação?

A relevância do trabalho se dá pela necessidade de reunir trabalhos sobre a temática para que se possa definir as técnicas e estratégias de forma mais objetiva e prática sobre as principais considerações relacionadas a

\section{METODOLOGIA}

Primordialmente, foi realizada uma análise baseada em artigos científicos, com o intuito de identificar a melhor relação custo/benefício, a fim de otimizar, não só o processo de implementação das redes de distribuição, como também, as manutenções futuras.

A revisão de literatura foi do tipo sistemática integrativa, com critérios de inclusão artigos científicos publicados nos últimos cinco anos e exclusão de artigos fora da temática abordada. Os artigos foram buscados através das bibliotecas SciELO e Periódicos CAPES, utilizando os descritores combinados com o operador dimensionamento otimizado em redes de distribuição de abastecimento de águas.

Objetiva-se com o presente trabalho realizar uma revisão de literatura, assim como, discutir em categorias, sobre otimização e dimensionamento de redes de distribuição de abastecimento de águas para subsidiar engenheiros e profissionais da área de instalações hidráulicas a solucionar problemas referente a perdas de cargas e otimização do processo para tornar a vazão de forma regular e diminuir os problemas nas redes de distribuição de abastecimentos e consequentemente a insatisfação do consumidor.

booleano And, conforme descrito no Quadro 1.

As informações contidas nesse estudo, foram coletadas e armazenadas nos quadros abaixo de acordo com cada etapa, para formação do banco de dados. Os dados foram analisados com o objetivo de trazer maior entendimento sobre o assunto, sendo assim foram realizadas pesquisas exploratórias, descritivas e explicativas. 
Quadro 1 - Detalhamento das etapas da Revisão Sistemática Integrativa.

\begin{tabular}{|c|c|c|c|}
\hline ETAPA & $\begin{array}{c}\text { TÓPICOS } \\
\text { DE CADA } \\
\text { ETAPA }\end{array}$ & \multicolumn{2}{|c|}{ DETALHAMENTO DE CADA TÓPICO } \\
\hline \multirow[t]{12}{*}{$1^{\mathrm{a}}$} & Tema & \multicolumn{2}{|c|}{ Otimização em redes de distribuição hidráulicas } \\
\hline & $\begin{array}{c}\text { Pergunta } \\
\text { norteadora }\end{array}$ & \multicolumn{2}{|c|}{$\begin{array}{l}\text { O presente trabalho está pautado na seguinte pergunta norteadora: quais } \\
\text { as principais considerações, elencadas por diferentes autores, } \\
\text { relacionadas a redução das perdas de carga em redes de distribuição de } \\
\text { abastecimento na busca de otimização e da melhor relação custo } \\
\text { benefício na sua implantação e operação? }\end{array}$} \\
\hline & Objetivo geral & \multicolumn{2}{|c|}{$\begin{array}{l}\text { Fazer uma análise baseada em outros artigos, com o intuito de identificar } \\
\text { a melhor relação custo/benefício referente a implementação das redes } \\
\text { de distribuição hidráulicas, otimizando o processo de implementação } \\
\text { das redes de distribuição de água. }\end{array}$} \\
\hline & $\begin{array}{l}\text { Estratégias de } \\
\text { busca }\end{array}$ & \multicolumn{2}{|c|}{$\begin{array}{l}\text { 1. Cruzamento de descritores por meio do operador booleano AND; } \\
\text { 2. Uso de aspas nos politermos (descritor com mais de um termo) para } \\
\text { que a varredura de artigos científicos contemplasse o termo exato; } \\
\text { 3. Uso de descritores estruturados (codificação) no DECS ou MESH; } \\
\text { 4. Uso de metadados (filtros) nas bibliotecas virtuais; }\end{array}$} \\
\hline & $\begin{array}{l}\text { Bancos de } \\
\text { terminologias }\end{array}$ & $\mathrm{DeCS}$ & $\underline{\text { http://decs.bvs.br/ }}$ \\
\hline & \multirow{4}{*}{$\begin{array}{l}\text { Descritores } \\
\text { livres e } \\
\text { estruturados }\end{array}$} & Descritor & DeCS (Registro) \\
\hline & & Dimensionamento & 51614 \\
\hline & & Abastecimento & 15285 \\
\hline & & $\begin{array}{l}\text { Instalações } \\
\text { Prediais }\end{array}$ & 25321 \\
\hline & $\begin{array}{l}\text { String de } \\
\text { busca }\end{array}$ & \multicolumn{2}{|c|}{$\begin{array}{l}\text { Dimensionamento And Abastecimento; Abastecimento And } \\
\text { "Instalações prediais" }\end{array}$} \\
\hline & \multirow{2}{*}{$\begin{array}{l}\text { Bibliotecas } \\
\text { Virtuais }\end{array}$} & Biblioteca & Link \\
\hline & & $\begin{array}{l}\text { Scielo } \\
\text { Periódicos da CAPI }\end{array}$ & $\begin{array}{l}\text { https://scielo.org/ } \\
\text { https://www-periodicos-capes-gov- } \\
\text { br.ezl.periodicos.capes.gov.br/index.php? }\end{array}$ \\
\hline \multirow[t]{3}{*}{$2^{a}$} & $\begin{array}{l}\text { Período de } \\
\text { coleta dos } \\
\text { dados }\end{array}$ & & Novembro de 2020 \\
\hline & $\begin{array}{l}\text { Critérios de } \\
\text { inclusão }\end{array}$ & \multicolumn{2}{|c|}{$\begin{array}{l}\text { 6. Artigos (artigo científicos e free). } \\
\text { 7. Publicação (2015-2020). } \\
\text { 8. Engenharias } \\
\text { 9. Brasil } \\
\text { 10. Recursos hídricos } \\
\text { 11. Qualquer idioma }\end{array}$} \\
\hline & $\begin{array}{l}\text { Critérios de } \\
\text { exclusão }\end{array}$ & \multicolumn{2}{|c|}{$\begin{array}{l}\text { 5. Artigos que não contemplam a temática } \\
\text { 6. Artigos com mais de } 5 \text { anos de publicação }\end{array}$} \\
\hline $3^{\mathrm{a}}$ & $\begin{array}{lr}\text { Número de } & \text { trabalhos } \\
\text { selecionados } & \text { para } \\
\text { revisão r sistemática } \\
\text { integrativa a } & \text { partir da } \\
\text { leitura dos } & \text { agentes } \\
\text { indexadores } & \text { das }\end{array}$ & $\begin{array}{r}\text { balhos } \\
\text { para } \\
\text { mática } \\
\text { rtir da } \\
\text { gentes } \\
\text { das }\end{array}$ & 8 \\
\hline
\end{tabular}




\begin{tabular}{|c|c|c|}
\hline & $\begin{array}{l}\text { publicações (tema, } \\
\text { descrição, ementa). }\end{array}$ & \\
\hline $4^{\mathrm{a}}$ & \begin{tabular}{lr}
\multicolumn{3}{c}{ Categorias obtidas com } \\
a análise dos \\
documentos \\
investigados \\
gratuitos e de line \\
acesso
\end{tabular} & \\
\hline $5^{\mathrm{a}}$ & $\begin{array}{l}\text { Análise, interpretação } \\
\text { e discussão dos } \\
\text { resultados }\end{array}$ & Ver em "Resultados e Discussão" \\
\hline $6^{\mathrm{a}}$ & $\begin{array}{l}\text { Apresentação } \text { da } \\
\text { revisão em formato de } \\
\text { artigo, o qual } \\
\text { contemple propostas } \\
\text { para estudos futuros }\end{array}$ & Este Artigo completo \\
\hline
\end{tabular}

Fonte: elaborada pelos autores.

\section{RESULTADOS}

Quadro 2 - Corresponde ao total de documentos disponíveis na Plataforma obtidos por string de busca.

\begin{tabular}{|l|c|c|c|c|}
\hline \multicolumn{1}{|c|}{ String de busca } & $\begin{array}{c}\text { Bases de } \\
\text { dados }\end{array}$ & $\begin{array}{c}\text { Total de } \\
\text { publicações } \\
\text { sem o filtro }\end{array}$ & $\begin{array}{c}\text { Publicações } \\
\text { disponíveis após } \\
\text { aplicar os filtros }\end{array}$ & $\begin{array}{c}\text { Publicações } \\
\text { aproveitadas na } \\
\text { Revisão Sistemática } \\
\text { Integrativa }\end{array}$ \\
\hline $\begin{array}{l}\text { Dimensionamento } \\
\text { And } \\
\text { Abastecimento; }\end{array}$ & $\begin{array}{c}\text { Periódicos da } \\
\text { Capes }\end{array}$ & 29 & 13 & 2 \\
\cline { 2 - 5 } & $\begin{array}{c}\text { Periódicos da } \\
\text { Capes }\end{array}$ & 86 & 37 & 2 \\
\hline $\begin{array}{l}\text { Abastecimento } \\
\text { And "Instalações } \\
\text { prediais" }\end{array}$ & Scielo & 1351 & 15 & 1 \\
\cline { 2 - 5 } & Scielo & 22 & 22 & 1 \\
\hline
\end{tabular}

Fonte: elaborada pelos autores.

Quadro 3- Descrição dos documentos (artigos) de acordo com os critérios de inclusão.

\begin{tabular}{|c|c|c|c|c|c|}
\hline$\underset{\mathbf{N}}{\mathbf{N}}$ & $\begin{array}{c}\text { Autor(a } \\
\text { ) }\end{array}$ & Tema & Link da publicação & $\begin{array}{c}\text { Data } \\
\text { de } \\
\text { public } \\
\text { ação }\end{array}$ & Conclusão \\
\hline 1 & $\begin{array}{l}\text { André } \\
\text { Luis } \\
\text { Mileo } \\
\text { Ferraiol } \\
\text { i Silva } \\
\text { André } \\
\text { Luiz } \\
\text { Amaran } \\
\text { te } \\
\text { Mesquit } \\
\text { a }\end{array}$ & $\begin{array}{l}\text { Simulação } \\
\text { do fator de } \\
\text { atrito para } \\
\text { o } \\
\text { escoamento } \\
\text { confinado } \\
\text { de caulim } \\
\text { com } \\
\text { diferentes } \\
\text { teores de } \\
\text { sólidos } \\
\text { pelo } \\
\text { modelo de }\end{array}$ & $\begin{array}{l}\text { https://www.scielo.br/scielo.php?script=sci } \\
\text { arttext\&pid=S1517- } \\
\text { 70762017000200422\&lang=pt }\end{array}$ & $\begin{array}{l}27 / 06 / \\
2017\end{array}$ & $\begin{array}{l}\text { As } \\
\text { suspensões } \\
\text { de caulim } \\
\mathrm{A}(65 \%), \\
\mathrm{B}(60 \%) \text { e } \\
\mathrm{C}(55 \%) \\
\text { possuem boa } \\
\text { operacionalid } \\
\text { ade nas } \\
\text { tubulações de } \\
0,2 \text { e } 0,3 \\
\text { metros de } \\
\text { diâmetro } \\
\text { para toda a }\end{array}$ \\
\hline
\end{tabular}




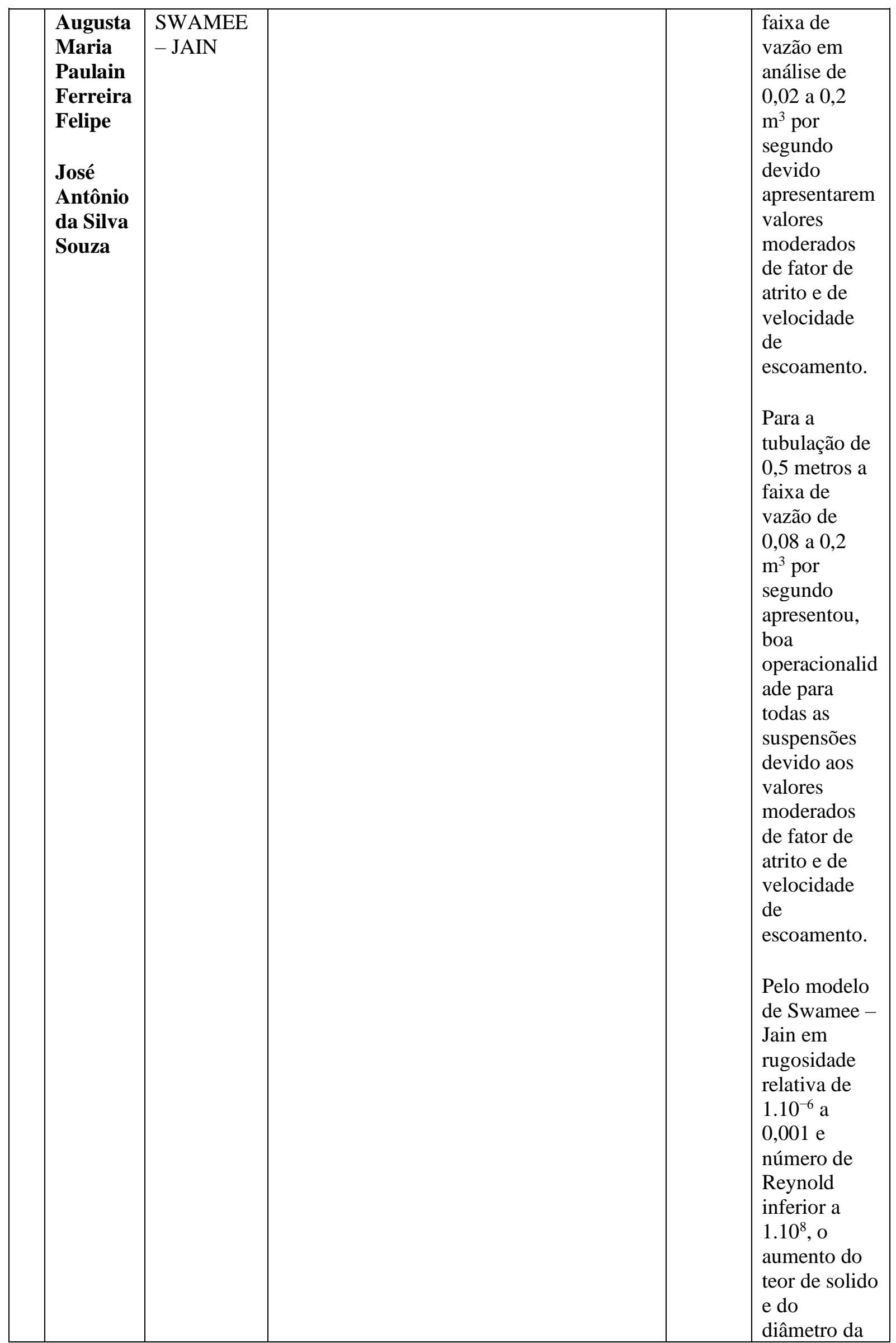




\begin{tabular}{|c|c|c|c|c|c|}
\hline & & & & & $\begin{array}{l}\text { tubulação } \\
\text { para faixa } \\
\text { operacional } \\
\text { de vazão } \\
\text { contribui } \\
\text { para o } \\
\text { aumento do } \\
\text { fator de atrito } \\
\text { no } \\
\text { escoamento } \\
\text { confinado de } \\
\text { caulim em } \\
\text { tubulação de } \\
\text { ferro } \\
\text { galvanizado } \\
\text { possibilitand } \\
\text { o o projeto e } \\
\text { o } \\
\text { acompanham } \\
\text { ento do } \\
\text { escoamento } \\
\text { de caulim de } \\
\text { forma mais } \\
\text { precisa, } \\
\text { contribuindo } \\
\text { para a } \\
\text { diminuição } \\
\text { do consumo } \\
\text { energético no } \\
\text { setor } \\
\text { mineral. }\end{array}$ \\
\hline 2 & $\begin{array}{l}\text { Marcos } \\
\text { Rodrigu } \\
\text { es } \\
\text { Pinnto } \\
\text { Marco } \\
\text { Aurélio } \\
\text { Holanda } \\
\text { de Castr } \\
\text { o }\end{array}$ & $\begin{array}{l}\text { Dimension } \\
\text { amento } \\
\text { econômico } \\
\text { otimizado } \\
\text { de redes de } \\
\text { distribuição } \\
\text { de água } \\
\text { consideran } \\
\text { do custos } \\
\text { de } \\
\text { manutençã } \\
\text { o }\end{array}$ & $\begin{array}{l}\text { https://www.scielo.br/scielo.php?script=sci } \\
\text { _arttext\&pid=S1413- } \\
41522017000100145 \& \text { lang=pt }\end{array}$ & $\begin{array}{l}27 / 10 / \\
2016\end{array}$ & $\begin{array}{l}\text { As obras de } \\
\text { saneamento } \\
\text { são } \\
\text { normalmente } \\
\text { executadas } \\
\text { por } \\
\text { governos. A } \\
\text { administraçã } \\
\text { o pública se } \\
\text { norteia por } \\
\text { princípios } \\
\text { específicos } \\
\text { para a sua } \\
\text { gestão, entre } \\
\text { eles, o } \\
\text { princípio da } \\
\text { eficiência, } \\
\text { inserido pela } \\
\text { Emenda } \\
\text { Constitucion } \\
\text { al número } \\
19, \text { de } 4 \text { de } \\
\text { junho de }\end{array}$ \\
\hline
\end{tabular}




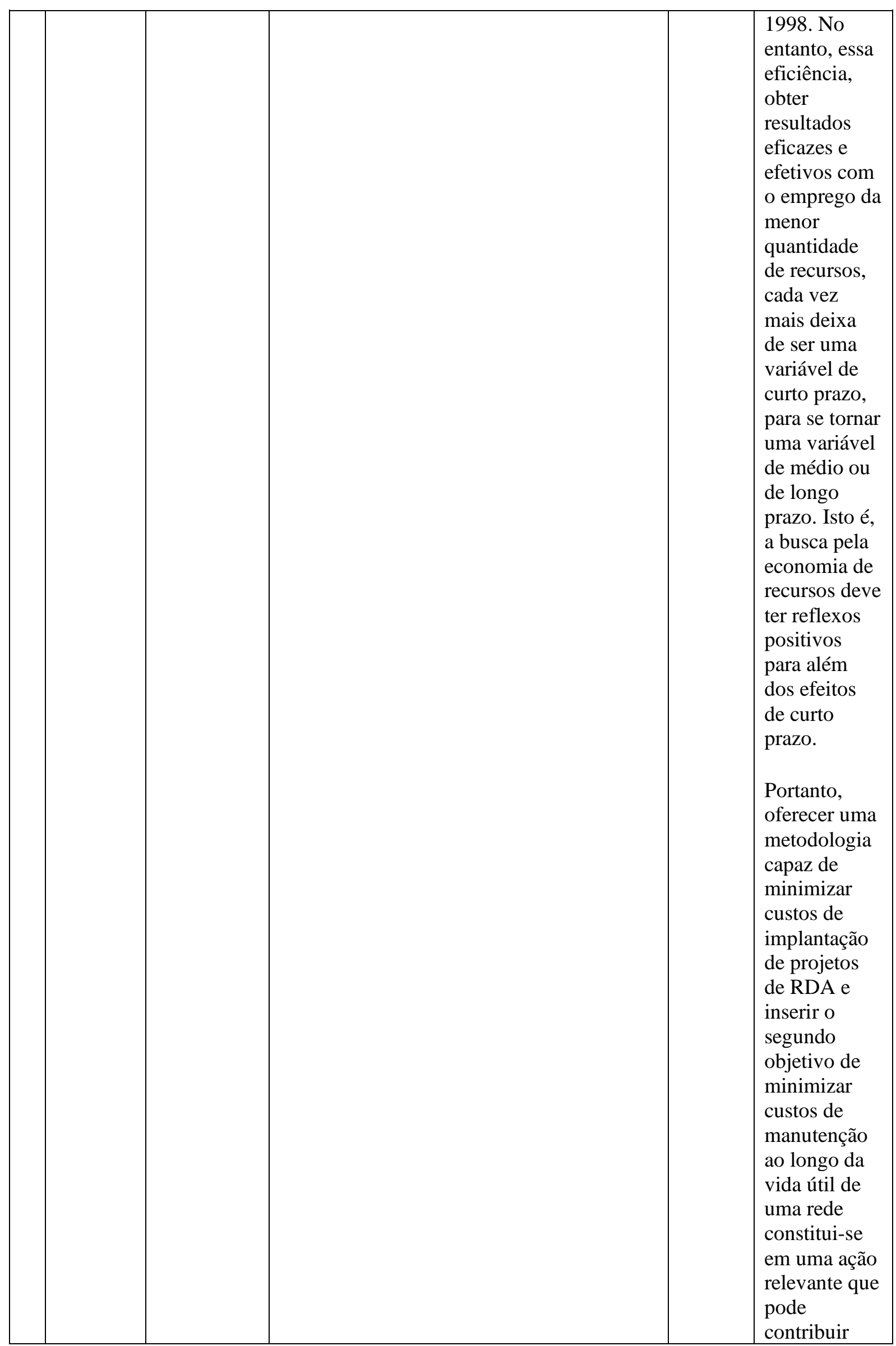




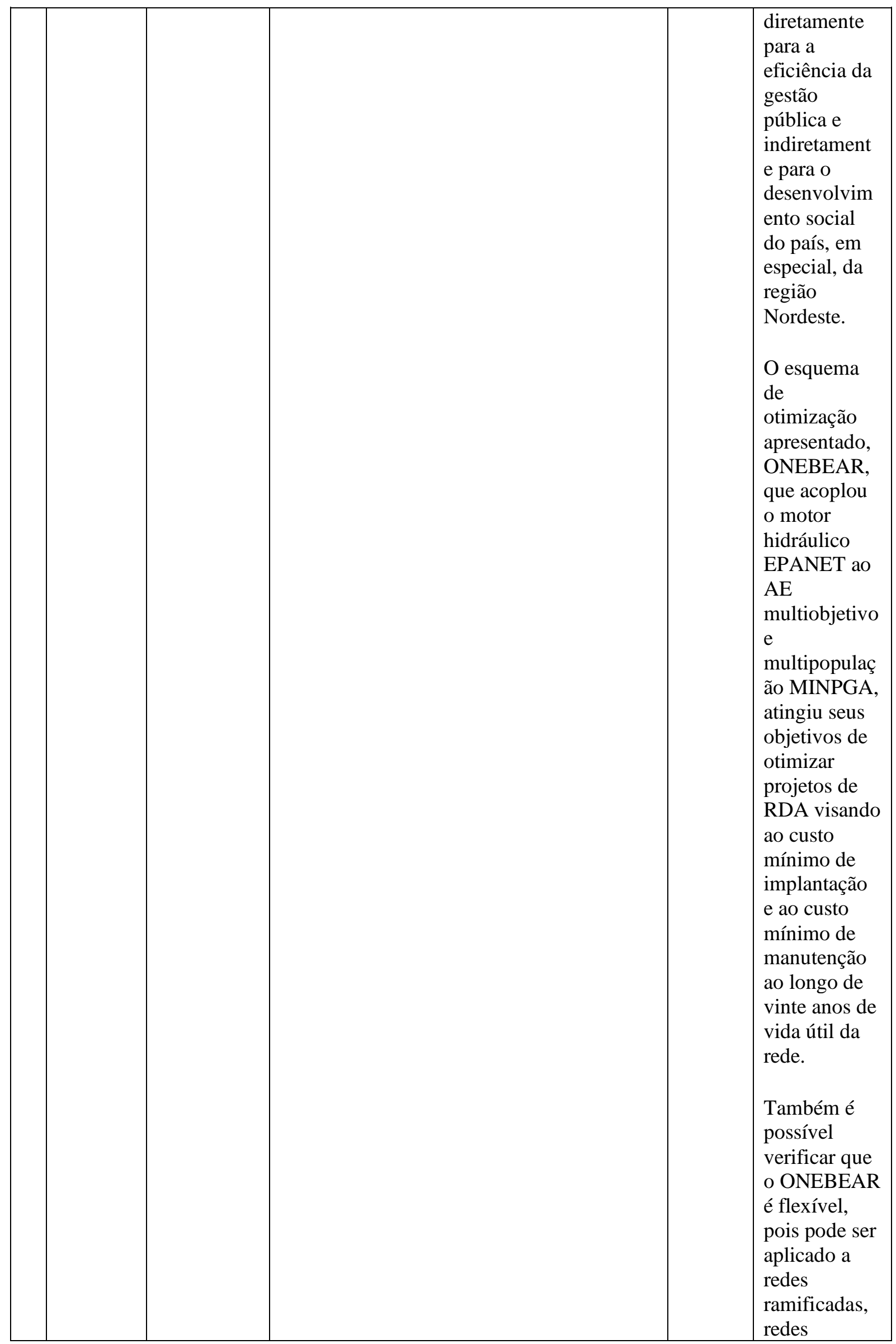




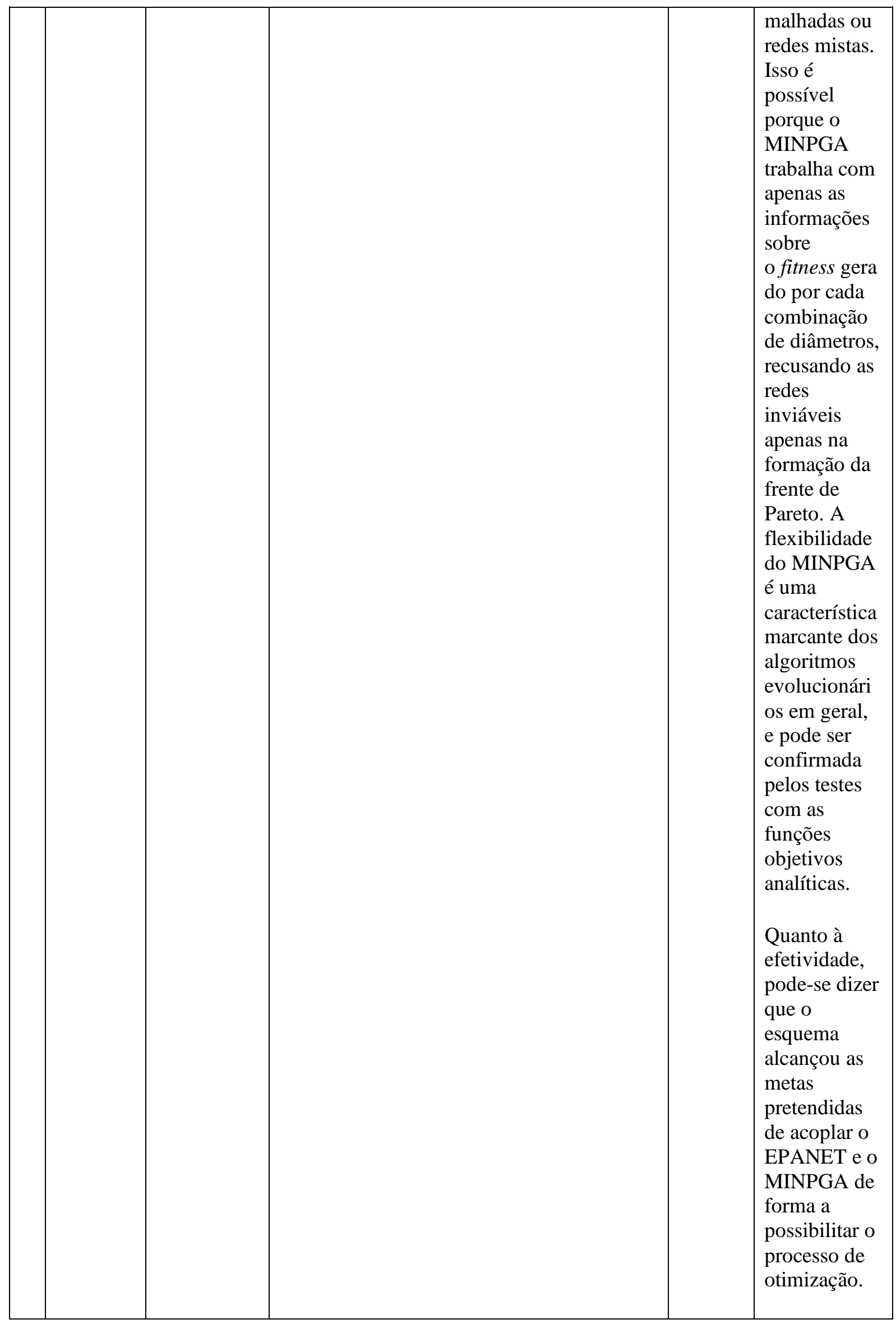




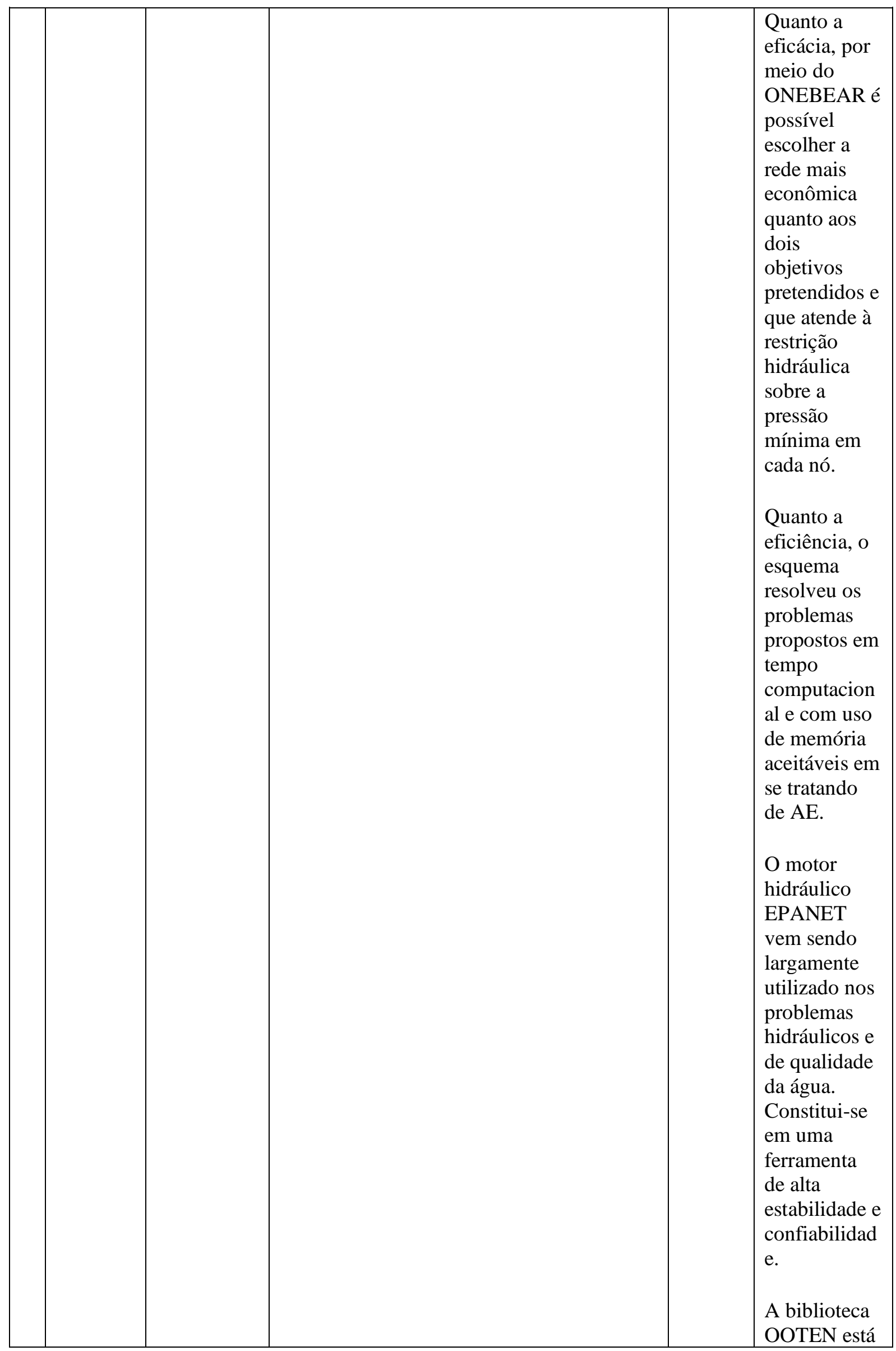




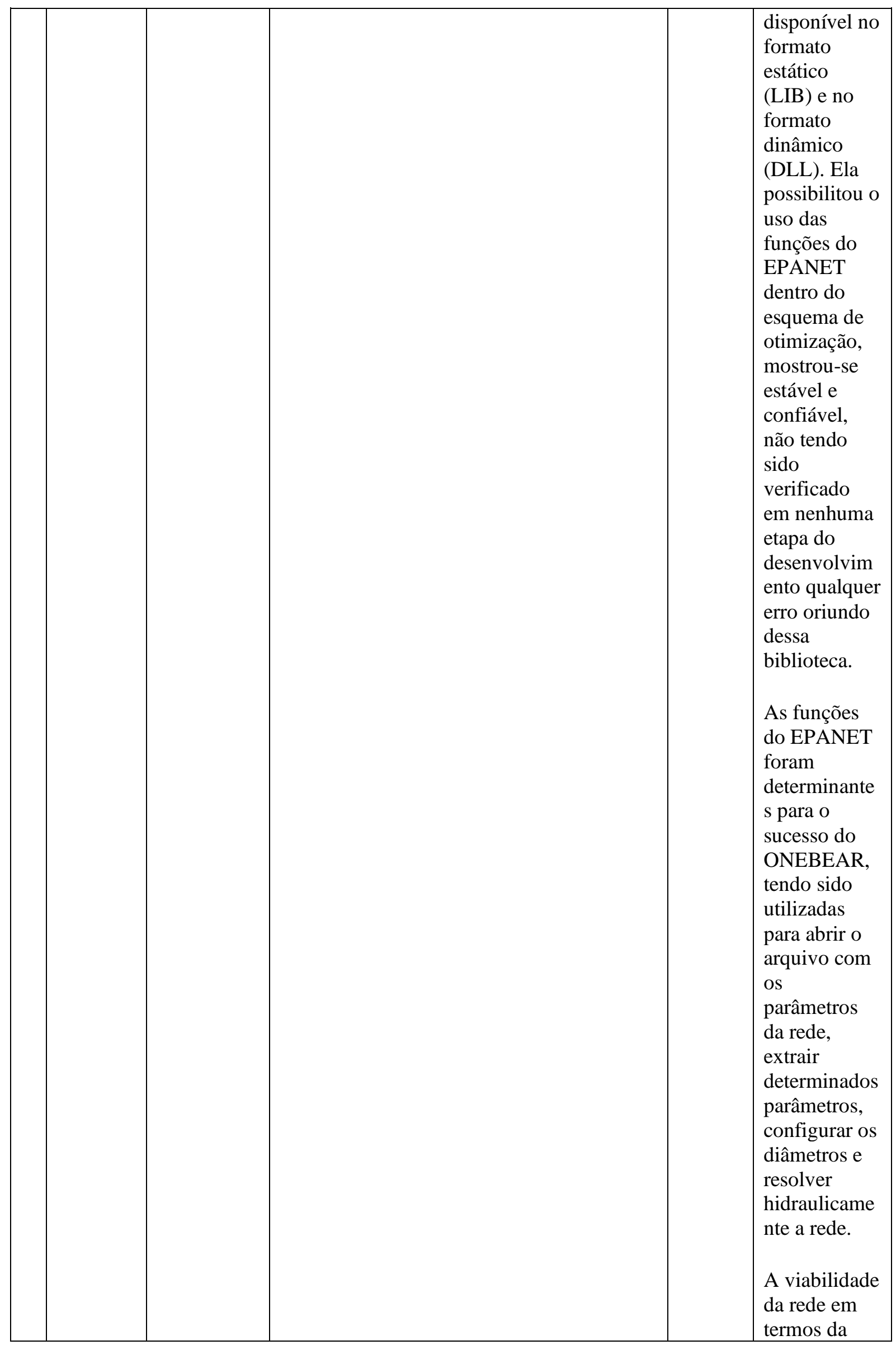




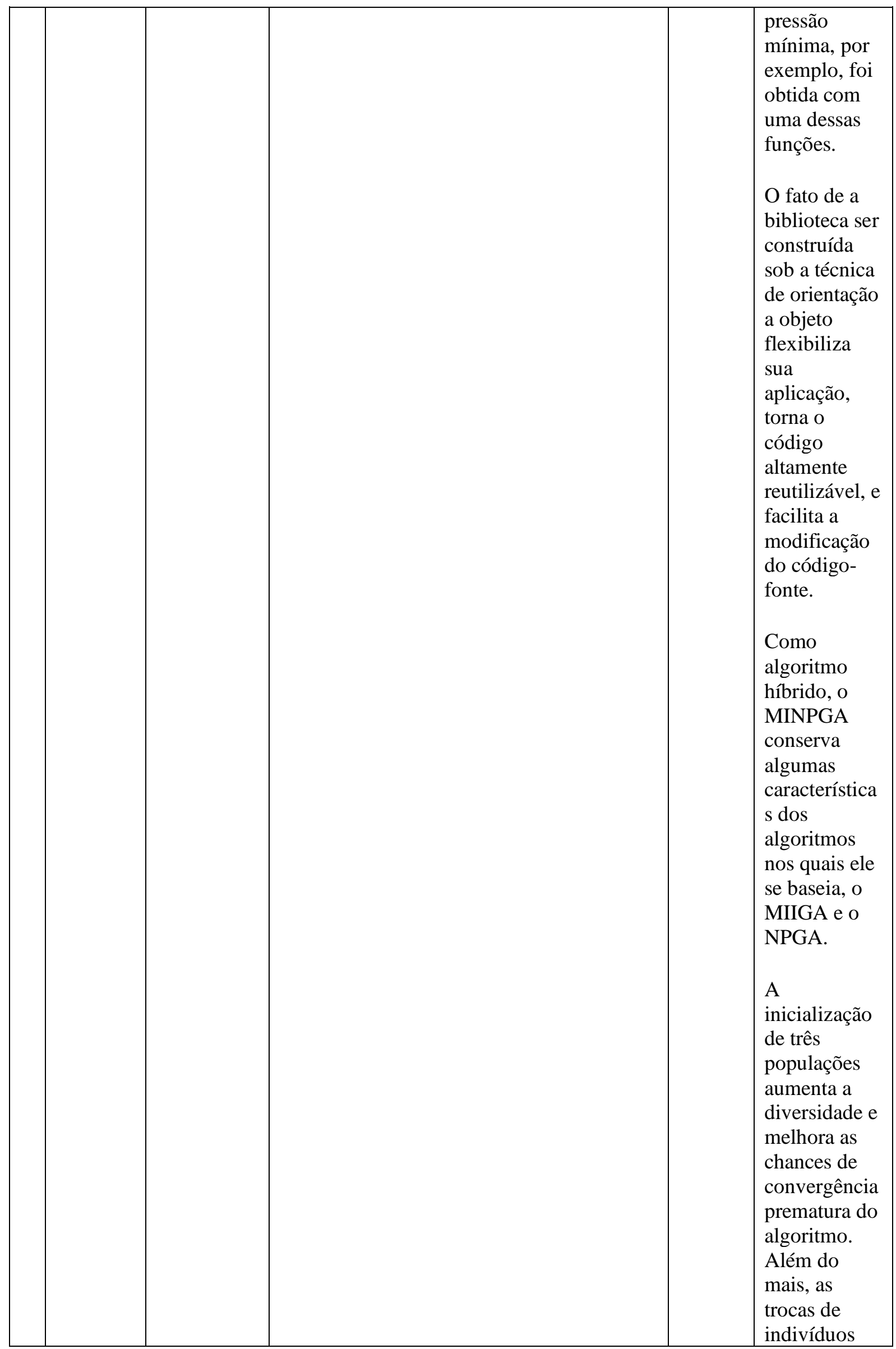




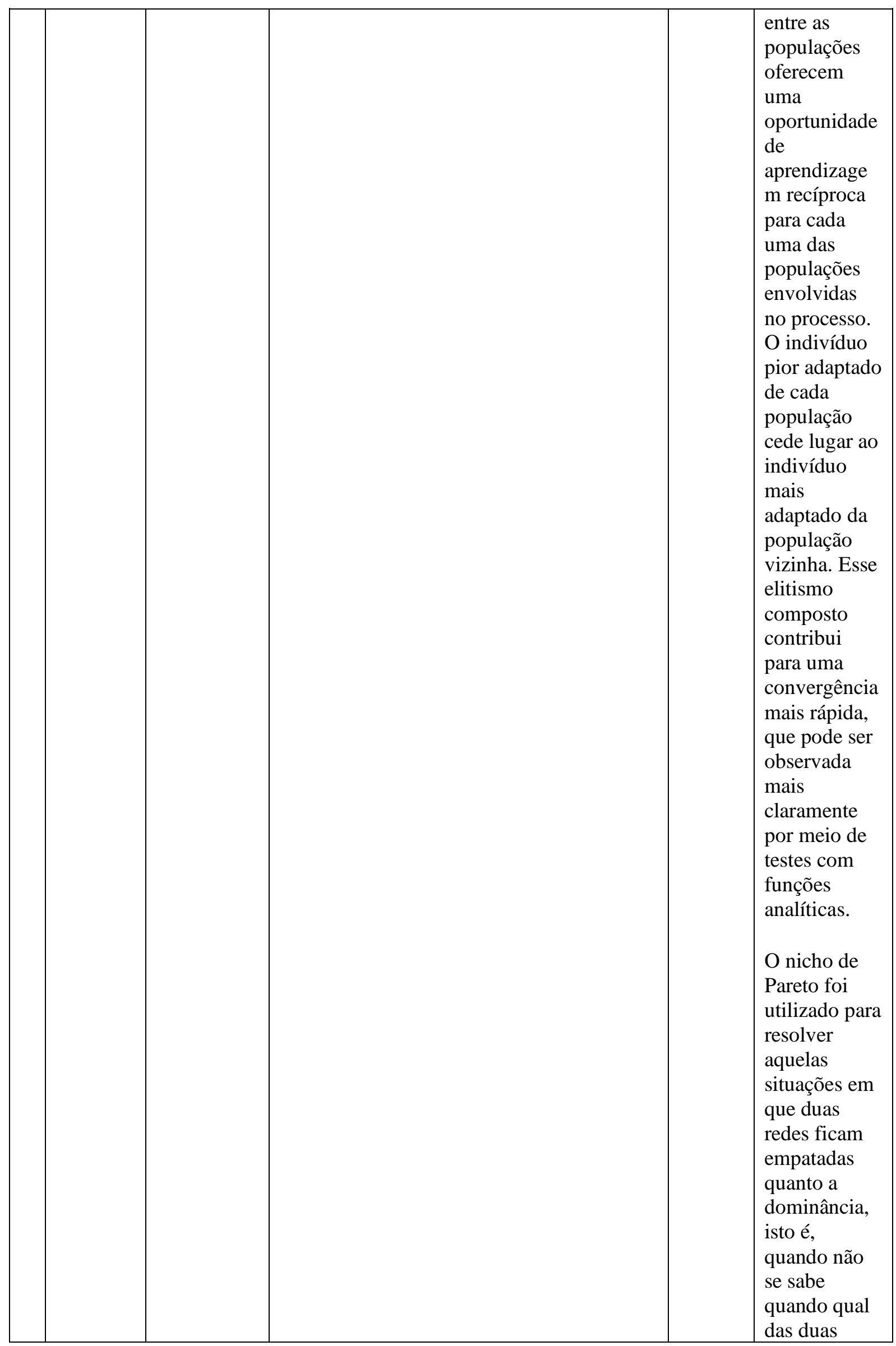




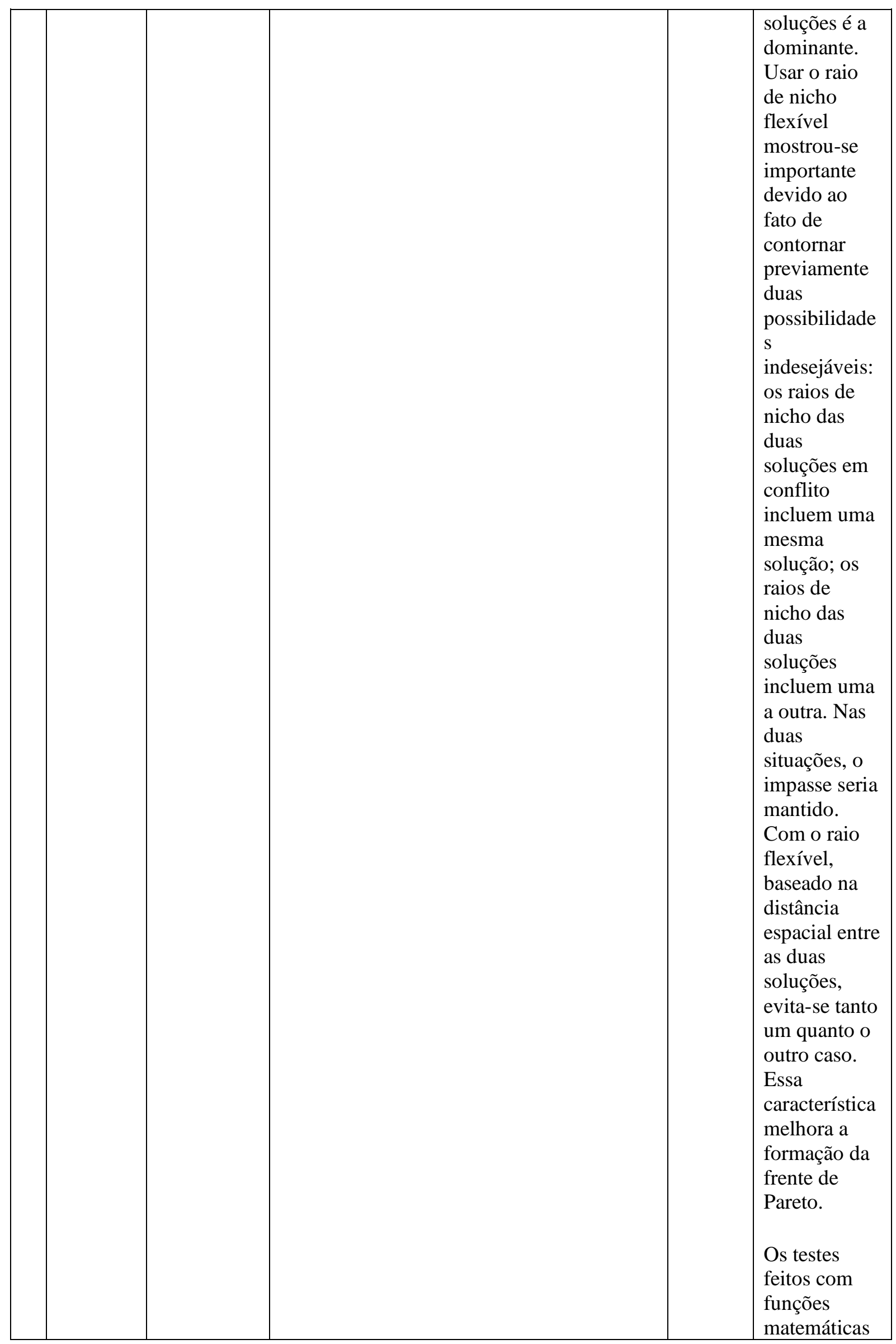




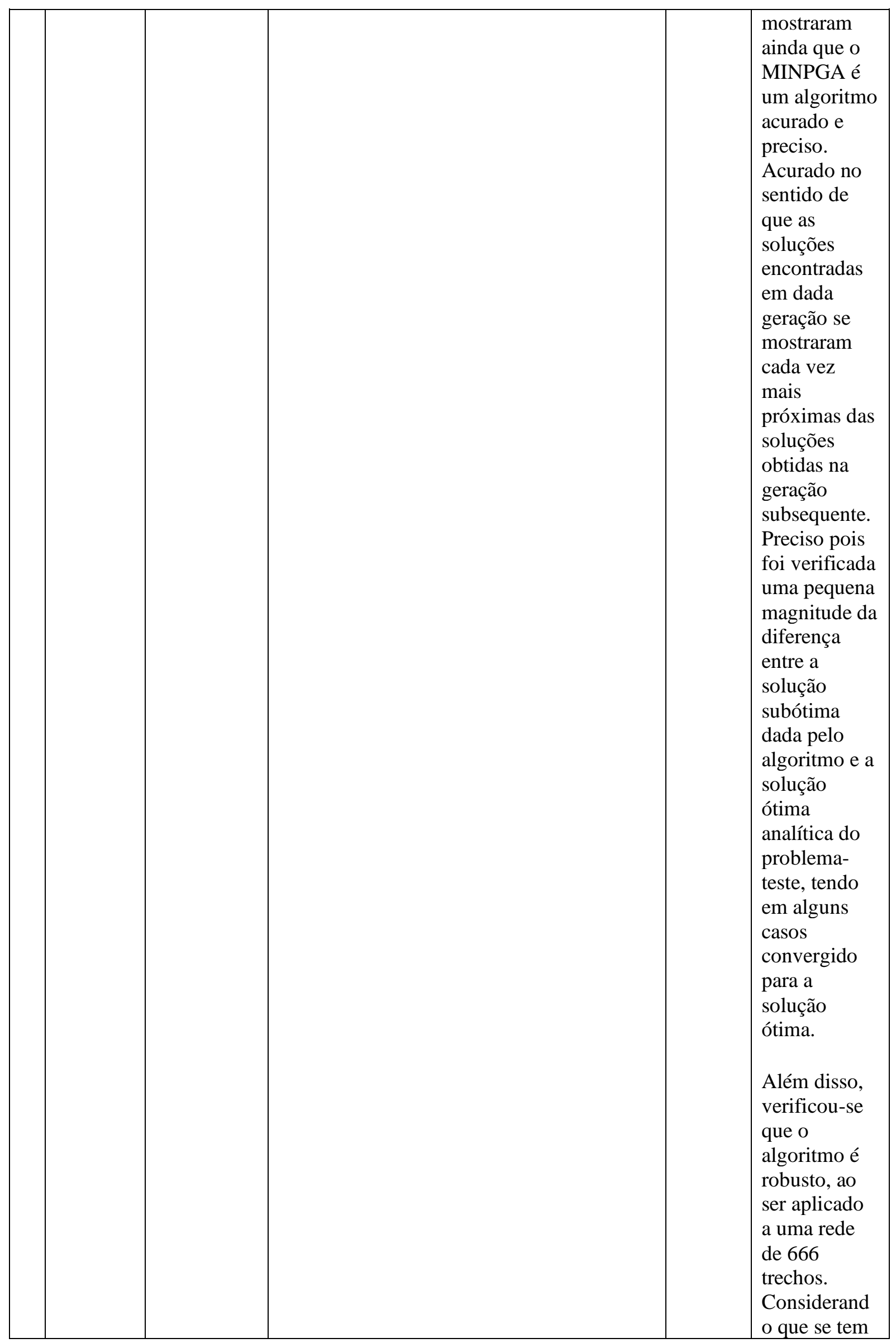




\begin{tabular}{|c|c|c|c|c|c|}
\hline & & & & & $\begin{array}{l}9 \text { diâmetros } \\
\text { possíveis } \\
\text { para cada um } \\
\text { desses } \\
\text { trechos, isso } \\
\text { representa } \\
\text { um problema } \\
\text { de } 6,73 \text { x } \\
10^{19} \text { combina } \\
\text { ções. Se cada } \\
\text { uma dessas } \\
\text { combinações } \\
\text { pudesse ser } \\
\text { testada em } \\
\text { um } \\
\text { nanosegundo } \\
\text {, levar-se-ia } \\
\text { mais de } 2 \text { mil } \\
\text { anos para } \\
\text { concluir o } \\
\text { processo. } \\
\text { Isso mostra } \\
\text { que a } \\
\text { aplicação do } \\
\text { MINPGA é } \\
\text { adequada ao } \\
\text { problema e } \\
\text { oferece boas } \\
\text { soluções em } \\
\text { um tempo } \\
\text { razoável. }\end{array}$ \\
\hline 3 & $\begin{array}{l}\text { Daniel } \\
\text { Manzi } \\
\text { Thaisa } \\
\text { Dias de } \\
\text { Castro } \\
\text { Goulart } \\
\text { Bruno } \\
\text { Melo } \\
\text { Brentan } \\
\text { Gustavo } \\
\text { Meirelle } \\
\text { s Lima } \\
\text { Edevar } \\
\text { Luvizott } \\
\text { o Junior }\end{array}$ & $\begin{array}{l}\text { Dimension } \\
\text { amento } \\
\text { ótimo de } \\
\text { redes de } \\
\text { distribuição } \\
\text { de água } \\
\text { com uso de } \\
\text { métodos de } \\
\text { otimização } \\
\text { inspirados } \\
\text { na natureza }\end{array}$ & $\begin{array}{l}\text { http://revistadae.com.br/artigos/artigo_edic } \\
\text { ao_212_n_1735.pdf }\end{array}$ & $\begin{array}{l}13 / 09 / \\
2017\end{array}$ & $\begin{array}{l}\text { Dada a } \\
\text { natureza } \\
\text { irrestrita dos } \\
\text { métodos } \\
\text { heurísticos, } \\
\text { há } \\
\text { necessidade } \\
\text { de } \\
\text { penalização } \\
\text { da função } \\
\text { objetivo para } \\
\text { atendimento } \\
\text { às restrições } \\
\text { físicas do } \\
\text { problema. Os } \\
\text { resultados } \\
\text { obtidos } \\
\text { demonstram } \\
\text { que há } \\
\text { influência }\end{array}$ \\
\hline
\end{tabular}




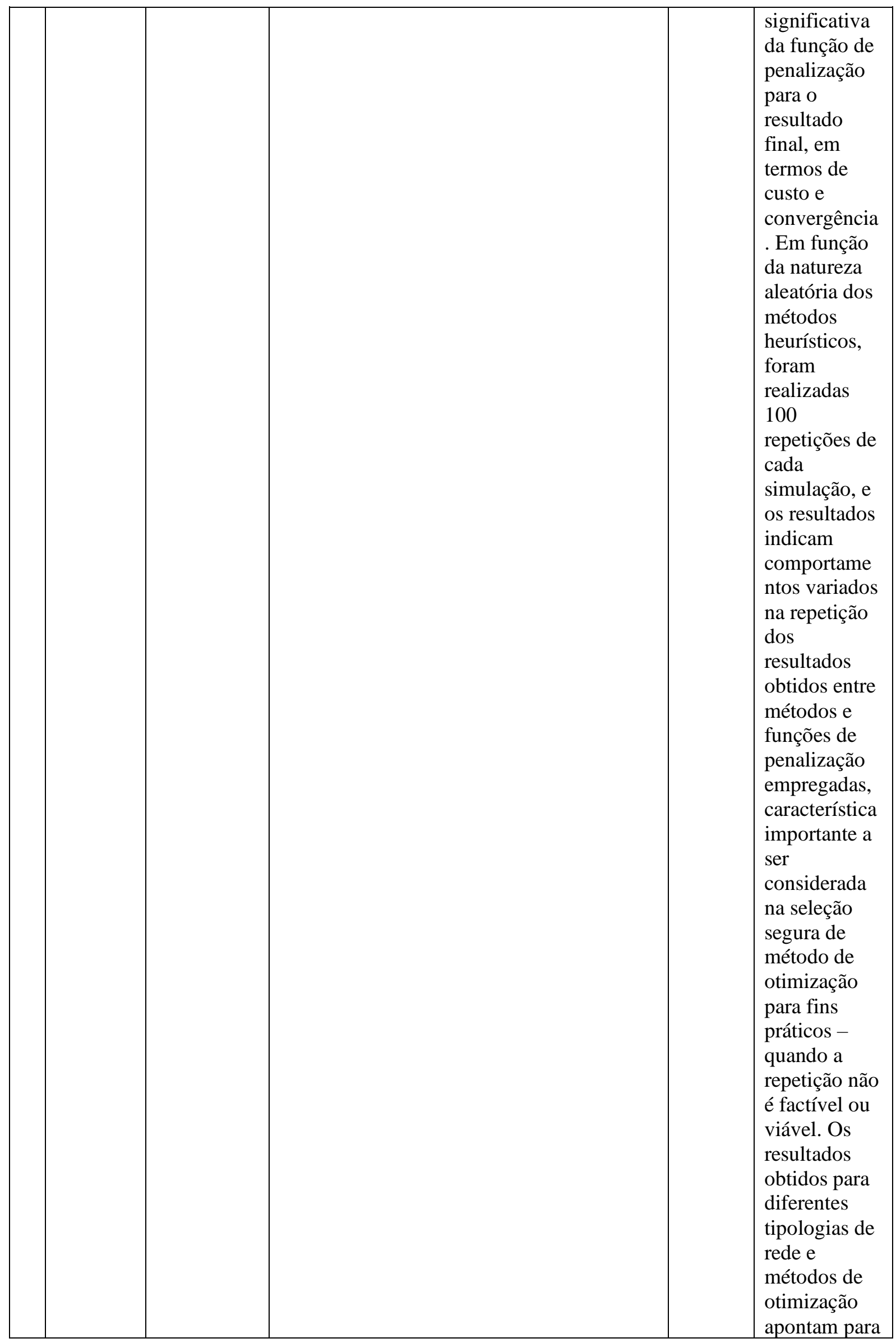




\begin{tabular}{|c|c|c|c|c|c|}
\hline & & & & & $\begin{array}{l}\text { relativa } \\
\text { vantagem da } \\
\text { função de } \\
\text { penalização } \\
\text { exponencial } \\
\text { (PEN3) que, } \\
\text { todavia, } \\
\text { mostrou-se } \\
\text { de difícil } \\
\text { aplicação em } \\
\text { alguns casos, } \\
\text { como para a } \\
\text { rede Hanoi. } \\
\text { A mesma } \\
\text { análise com } \\
\text { relação aos } \\
\text { métodos de } \\
\text { otimização } \\
\text { empregados } \\
\text { revela } \\
\text { desempenhos } \\
\text { ora } \\
\text { vantajosos, } \\
\text { ora } \\
\text { desvantajoso } \\
\text { s para cada } \\
\text { método em } \\
\text { função da } \\
\text { tipologia de } \\
\text { rede e função } \\
\text { de } \\
\text { penalização, } \\
\text { porém com } \\
\text { presença do } \\
\text { ABC e do } \\
\text { SLC entre os } \\
\text { melhores } \\
\text { resultados } \\
\text { em todas as } \\
\text { aplicações } \\
\text { realizadas. }\end{array}$ \\
\hline 4 & $\begin{array}{l}\text { Gustavo } \\
\text { Meirelle } \\
\text { s Lima } \\
\\
\text { Bruno } \\
\text { Melo } \\
\text { Brentan } \\
\\
\text { Antonio } \\
\text { Carlos } \\
\text { Zuffo }\end{array}$ & $\begin{array}{l}\text { Dimension } \\
\text { amento de } \\
\text { redes de } \\
\text { distribuição } \\
\text { de água por } \\
\text { meio de } \\
\text { análise } \\
\text { multicriteri } \\
\text { al }\end{array}$ & $\begin{array}{l}\text { http://revistadae.com.br/artigos/artigo_edic } \\
\text { ao_221_n_1831.pdf }\end{array}$ & $\begin{array}{l}27 / 06 / \\
2018\end{array}$ & $\begin{array}{l}\text { Atualmente, } \\
\text { diversos } \\
\text { trabalhos têm } \\
\text { focado no } \\
\text { dimensionam } \\
\text { ento de redes } \\
\text { de } \\
\text { abasteciment } \\
\text { o de água } \\
\text { apenas em } \\
\text { seu custo de } \\
\text { implantação. } \\
\text { Entretanto, }\end{array}$ \\
\hline
\end{tabular}




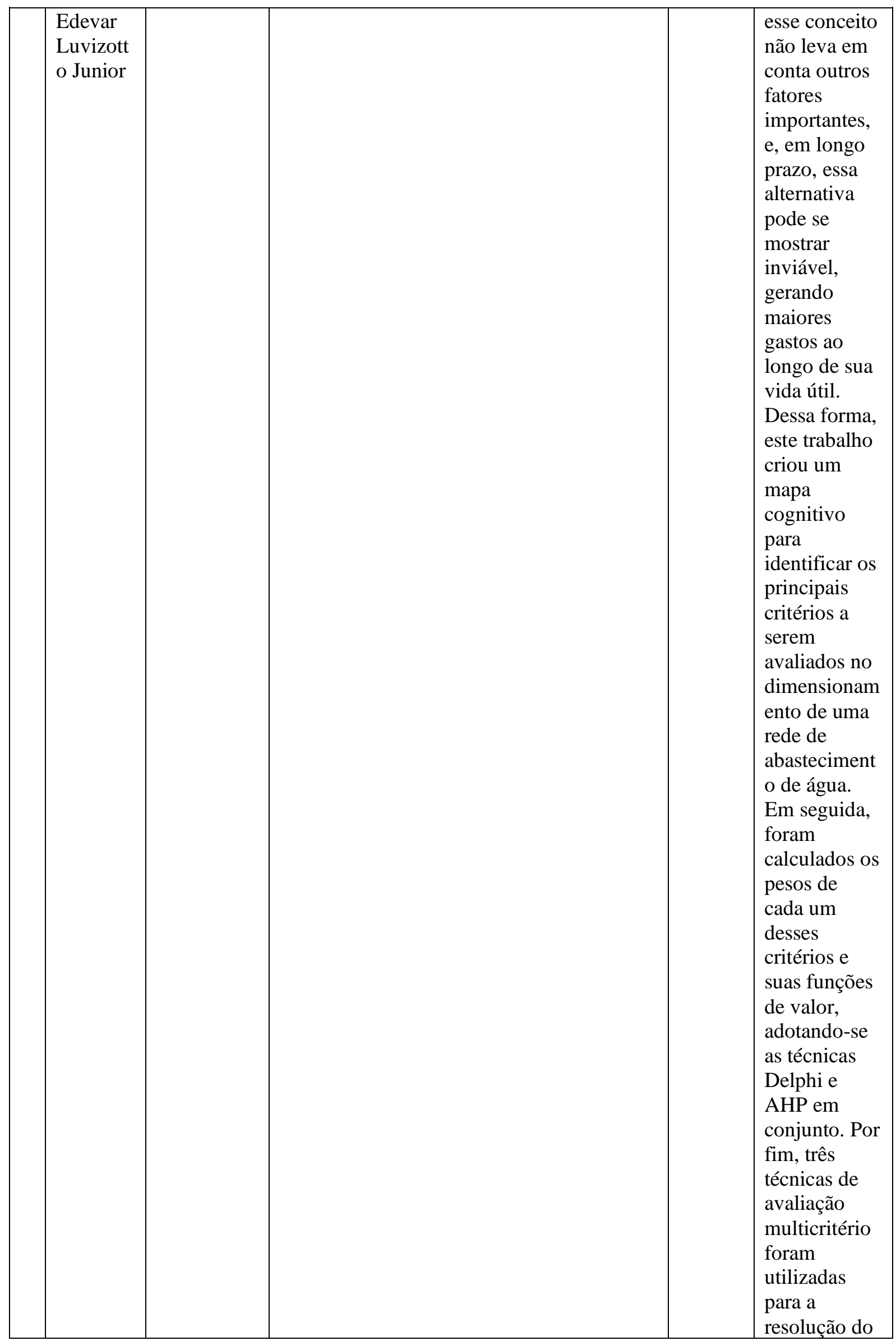




\begin{tabular}{|c|c|c|c|c|c|}
\hline & . & & & & $\begin{array}{l}\text { estudo de } \\
\text { caso } \\
\text { apresentado: } \\
\text { AHP, Electre } \\
\text { II e } \\
\text { Promethee. } \\
\text { Observou- - } \\
\text { se uma boa } \\
\text { concordância } \\
\text { entre os } \\
\text { métodos, } \\
\text { demonstrand } \\
\text { o sua } \\
\text { aplicabilidad } \\
\text { e nesse tipo } \\
\text { de problema. } \\
\text { No estudo de } \\
\text { caso } \\
\text { apresentado, } \\
\text { devido aos } \\
\text { pesos e às } \\
\text { funções de } \\
\text { valor } \\
\text { adotadas, a } \\
\text { melhor } \\
\text { alternativa } \\
\text { coincidiu } \\
\text { com a de } \\
\text { menor custo. } \\
\text { Entretanto } \\
\text { esse } \\
\text { resultado é } \\
\text { dependente } \\
\text { do } \\
\text { julgamento } \\
\text { dos decisores } \\
\text { ao } \\
\text { determinare } \\
\text { m os pesos } \\
\text { dos critérios } \\
\text { e suas } \\
\text { funções de } \\
\text { valor, sendo } \\
\text { o resultado } \\
\text { final o } \\
\text { reflexo dos } \\
\text { interesses } \\
\text { prioritários } \\
\text { de cada } \\
\text { sistema. }\end{array}$ \\
\hline 5 & $\begin{array}{l}\text { Erich Ke } \\
\text { llner }\end{array}$ & $\begin{array}{l}\text { Avaliação } \\
\text { da } \\
\text { rugosidade } \\
\text { relativa dos }\end{array}$ & $\begin{array}{l}\text { https://www.scielo.br/scielo.php?script=sci } \\
\text { _arttext\&pid=S1413- } \\
41522016000200347 \& \operatorname{lng}=\text { pt\&tlng=pt }\end{array}$ & $\begin{array}{l}20 / 06 / \\
2016\end{array}$ & $\begin{array}{l}\text { As } \\
\text { tubulações } \\
\text { em PVC } \\
\text { (marrom) } \\
\end{array}$ \\
\hline
\end{tabular}




\begin{tabular}{|c|c|c|}
\hline $\begin{array}{l}\text { Jorge Ak } \\
\text { utsu } \\
\text { Luisa } \\
\text { Fernand } \\
\text { a } \\
\text { Ribeiro } \\
\text { Reis }\end{array}$ & $\begin{array}{l}\text { tubos de } \\
\text { PVC com } \\
\text { vistas ao } \\
\text { dimensiona } \\
\text { mento das } \\
\text { redes de } \\
\text { distribuição } \\
\text { de água }\end{array}$ & $\begin{array}{l}\text { com DN } 50, \\
75 \text { e 100, } \\
\text { novas, } \\
\text { apresentaram } \\
\text { rugosidade } \\
\text { média } \\
\text { variável de } \\
5,31 \pm 0,78 \mu \text { m } \\
\text { a } \\
30,95 \pm 3,71 \mu \\
\text { m. } \\
\text { Já aquelas } \\
\text { com DN } 50 \text { e } \\
10 \text { anos de } \\
\text { uso tiveram } \\
\text { rugosidade } \\
\text { média de } \\
56,42 \pm 22,09 \\
\mu \text { m, } \\
\text { enquanto as } \\
\text { tubulações } \\
\text { em PVC } \\
\text { (marrom) } \\
\text { com DN } 75 \text { e } \\
34 \text { anos de } \\
\text { uso } \\
\text { mostraram } \\
\text { uma de } \\
35,98 \pm 23,79 \\
\mu \text { m. } \\
\text { Para as } \\
\text { condições de } \\
\text { escoamento } \\
\text { observadas } \\
\text { em redes de } \\
\text { distribuição } \\
\text { de água, com } \\
30.000 \leq R e \leq 7 \\
50.000, \text { e } \\
\text { construídas } \\
\text { em PVC } \\
\text { (marrom), a } \\
\text { rugosidade } \\
\text { relativa } \\
\left(\varepsilon / D_{i} \text { ) não }\right. \\
\text { influenciou } \\
\text { significativa } \\
\text { mente os } \\
\text { valores do } \\
\text { fator de atrito } \\
\text { (f). }\end{array}$ \\
\hline
\end{tabular}




\begin{tabular}{|c|c|c|c|c|c|}
\hline & & & & & $\begin{array}{l}\text { O diâmetro } \\
\text { interno da } \\
\text { tubulação } \\
\text { exerce } \\
\text { grande } \\
\text { influência } \\
\text { sobre a } \\
\text { determinação } \\
\text { da perda da } \\
\text { carga de } \\
\text { pressão, que } \\
\text { deveria ter } \\
\text { seu valor } \\
\text { mais } \\
\text { provável } \\
\text { estabelecido } \\
\text { pela } \\
\text { Associação } \\
\text { Brasileira de } \\
\text { Normas } \\
\text { Técnicas, } \\
\text { quando da } \\
\text { revisão da } \\
\text { NBR 5647- } \\
\text { 3:1999. }\end{array}$ \\
\hline 6 & $\begin{array}{l}\text { Alex } \\
\text { Takeo } \\
\text { Yasumur } \\
\text { a } \\
\text { Lima Sil } \\
\text { va } \\
\text { Fernand } \\
\text { o das } \\
\text { Graças } \\
\text { Braga } \\
\text { da Silva } \\
\text { André } \\
\text { Carlos } \\
\text { da Silva } \\
\text { José } \\
\text { Antonio } \\
\text { Tosta } \\
\text { dos Reis } \\
\text { Claudio } \\
\text { Lindemb } \\
\text { erg } \\
\text { de Freita } \\
\text { s }\end{array}$ & $\begin{array}{l}\text { Proposição } \\
\text { de } \\
\text { estratégia } \\
\text { operacional } \\
\text { ótima } \\
\text { aplicada a } \\
\text { rede de } \\
\text { distribuição } \\
\text { de água } \\
\text { com } \\
\text { abordagem } \\
\text { estatistica }\end{array}$ & $\begin{array}{l}\text { https://www.scielo.br/scielo.php?script=sci } \\
\text { _arttext\&pid=S1980- } \\
\text { 993X2020000200304\&lang=pt }\end{array}$ & $\begin{array}{l}09 / 04 / \\
2020\end{array}$ & $\begin{array}{l}\text { The genetic } \\
\text { algorithm of } \\
\text { optimization } \\
\text { obtained a } \\
\text { good } \\
\text { performance, } \\
\text { being able to } \\
\text { maintain } \\
\text { pressures } \\
\text { within } \\
\text { established } \\
\text { limits in the } \\
\text { study and } \\
\text { indicated the } \\
\text { quantity of } \\
\text { pumps and } \\
\text { valves } \\
\text { employed, as } \\
\text { well as } \\
\text { pumping } \\
\text { pressures or } \\
\text { the head loss } \\
\text { generated by } \\
\text { the valves } \\
\text { and portions } \\
\text { of pumps and } \\
\text { valve } \\
\text { implantation. } \\
\text { Thus, the }\end{array}$ \\
\hline
\end{tabular}




\begin{tabular}{|c|c|c|c|c|c|}
\hline & $\begin{array}{l}\text { Victor } \\
\text { Eduardo } \\
\text { de } \\
\text { Mello V } \\
\text { alério }\end{array}$ & & & & $\begin{array}{l}\text { planning of } \\
\text { experiments } \\
\text { proved to be } \\
\text { a potential } \\
\text { tool to assist } \\
\text { in the } \\
\text { operation } \\
\text { optimization } \\
\text { of a water } \\
\text { distribution } \\
\text { network, } \\
\text { making } \\
\text { possible } \\
\text { optimization } \\
\text { of the } \\
\text { equation of } \\
\text { obtained } \\
\text { response } \\
\text { surface and, } \\
\text { consequently } \\
\text { obtention of } \\
\text { optimal } \\
\text { parameters } \\
\text { and } \\
\text { evaluation of } \\
\text { interactions. } \\
\text { However, } \\
\text { more studies } \\
\text { should be } \\
\text { done to } \\
\text { evaluate } \\
\text { performance } \\
\text { on more } \\
\text { complex and } \\
\text { real network } \\
\text { scenarios to } \\
\text { validate the } \\
\text { tool under } \\
\text { different } \\
\text { conditions. }\end{array}$ \\
\hline 7 & $\begin{array}{l}\text { Danielle } \\
\text { Costa } \\
\text { Morais } \\
\text { Cristiano } \\
\text { A. } \\
\text { Virgínio } \\
\text { Cavalca } \\
\text { nte } \\
\text { Adiel } \\
\text { Teixeira } \\
\text { de } \\
\text { Almeida }\end{array}$ & $\begin{array}{l}\text { Priorização } \\
\text { de áreas de } \\
\text { controle de } \\
\text { perdas em } \\
\text { redes de } \\
\text { distribuição } \\
\text { de água }\end{array}$ & $\begin{array}{l}\text { https://www.scielo.br/scielo.php?script=sci } \\
\text { arttext\&pid=S0101- } \\
74382010000100002 \& \text { lang=pt }\end{array}$ & $\begin{array}{l}04 / 201 \\
0\end{array}$ & $\begin{array}{l}\text { Neste } \\
\text { trabalho, foi } \\
\text { apresentado } \\
\text { um modelo } \\
\text { multicritério } \\
\text { baseado no } \\
\text { método } \\
\text { PROMETHE } \\
\text { E I para a } \\
\text { priorização } \\
\text { das áreas } \\
\text { críticas de } \\
\text { perdas de } \\
\text { uma cidade, }\end{array}$ \\
\hline
\end{tabular}




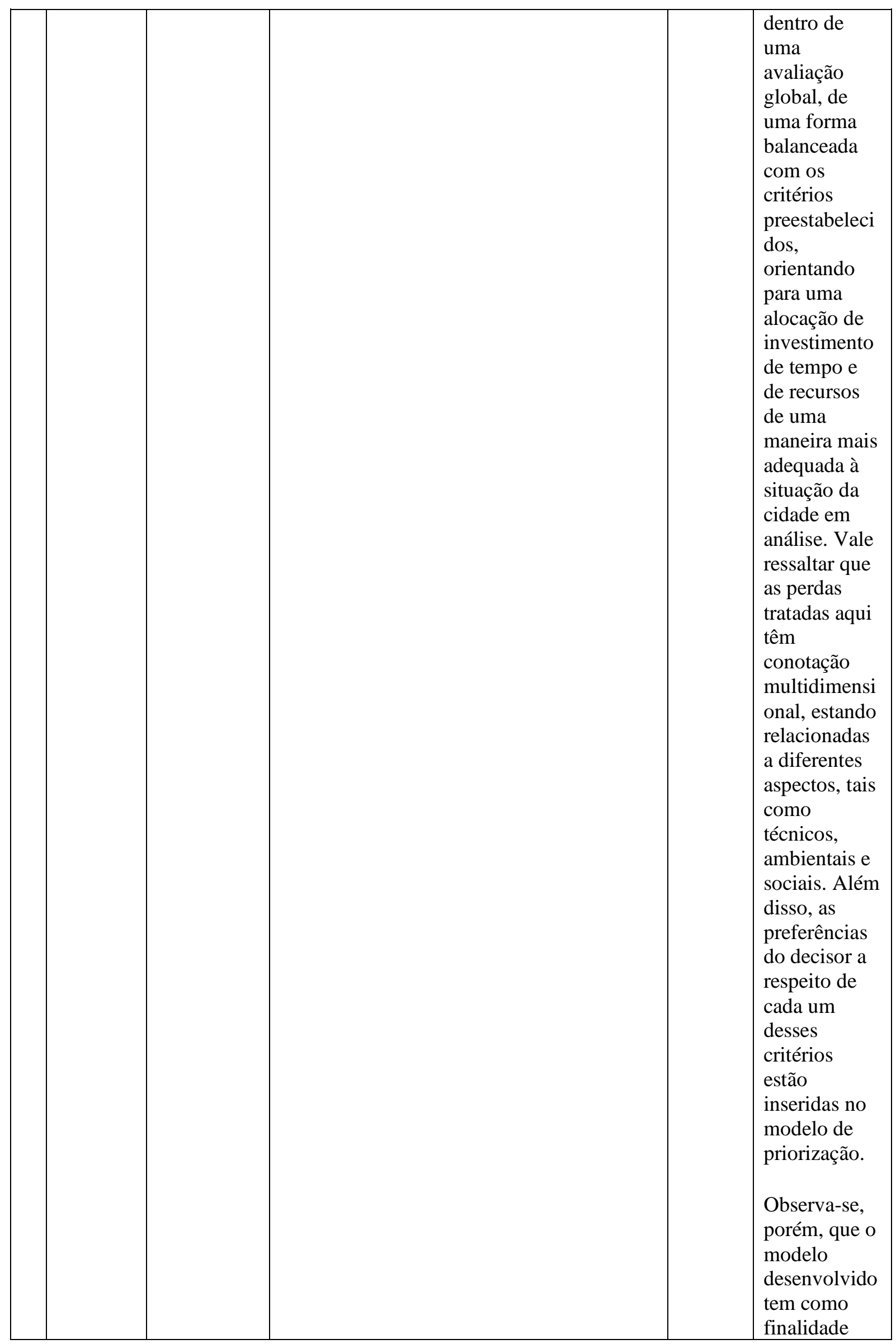




\begin{tabular}{|c|c|c|c|c|c|}
\hline & & & & & $\begin{array}{l}\text { principal } \\
\text { ilustrar o } \\
\text { emprego da } \\
\text { abordagem } \\
\text { proposta. } \\
\text { Para tanto, } \\
\text { limitou-se às } \\
\text { alternativas } \\
\text { estudadas e } \\
\text { aos critérios } \\
\text { levantados } \\
\text { pelo decisor. } \\
\text { Assim, } \\
\text { possivelment } \\
\text { e uma } \\
\text { quantidade } \\
\text { mais } \\
\text { significativa } \\
\text { de critérios } \\
\text { poderia ter } \\
\text { sido } \\
\text { considerada } \\
\text { na análise, o } \\
\text { que } \\
\text { obviamente } \\
\text { modificaria o } \\
\text { seu resultado } \\
\text { final. Além } \\
\text { disso, } \\
\text { observa-se } \\
\text { que, apesar } \\
\text { de o modelo } \\
\text { ter sido } \\
\text { aplicado para } \\
\text { uma cidade } \\
\text { de pequeno } \\
\text { porte, ajusta- } \\
\text { se } \\
\text { perfeitament } \\
\text { e a } \\
\text { problemas } \\
\text { semelhantes, } \\
\text { que } \\
\text { envolvem } \\
\text { grandes } \\
\text { cidades. }\end{array}$ \\
\hline 8 & $\begin{array}{l}\text { Fátima } \\
\text { C. } \\
\text { Soares } \\
\text { Guilher } \\
\text { me C. } \\
\text { Teles }\end{array}$ & $\begin{array}{l}\text { Aferição } \\
\text { dos Valores } \\
\text { dos } \\
\text { Comprimen } \\
\text { tos } \\
\text { Equivalente } \\
\text { s Utilizados } \\
\text { na } \\
\end{array}$ & $\begin{array}{l}\text { http://www.scielo.org.ar/scielo.php?script= } \\
\text { sci_arttext\&pid=S1851- } \\
\text { 75872015000200003\&lang=pt }\end{array}$ & $\begin{array}{l}03 / 07 / \\
2015\end{array}$ & $\begin{array}{l}\text { De acordo } \\
\text { com a } \\
\text { metodologia } \\
\text { utilizada e } \\
\text { nas } \\
\text { condições em } \\
\text { que o } \\
\text { trabalho foi }\end{array}$ \\
\hline
\end{tabular}




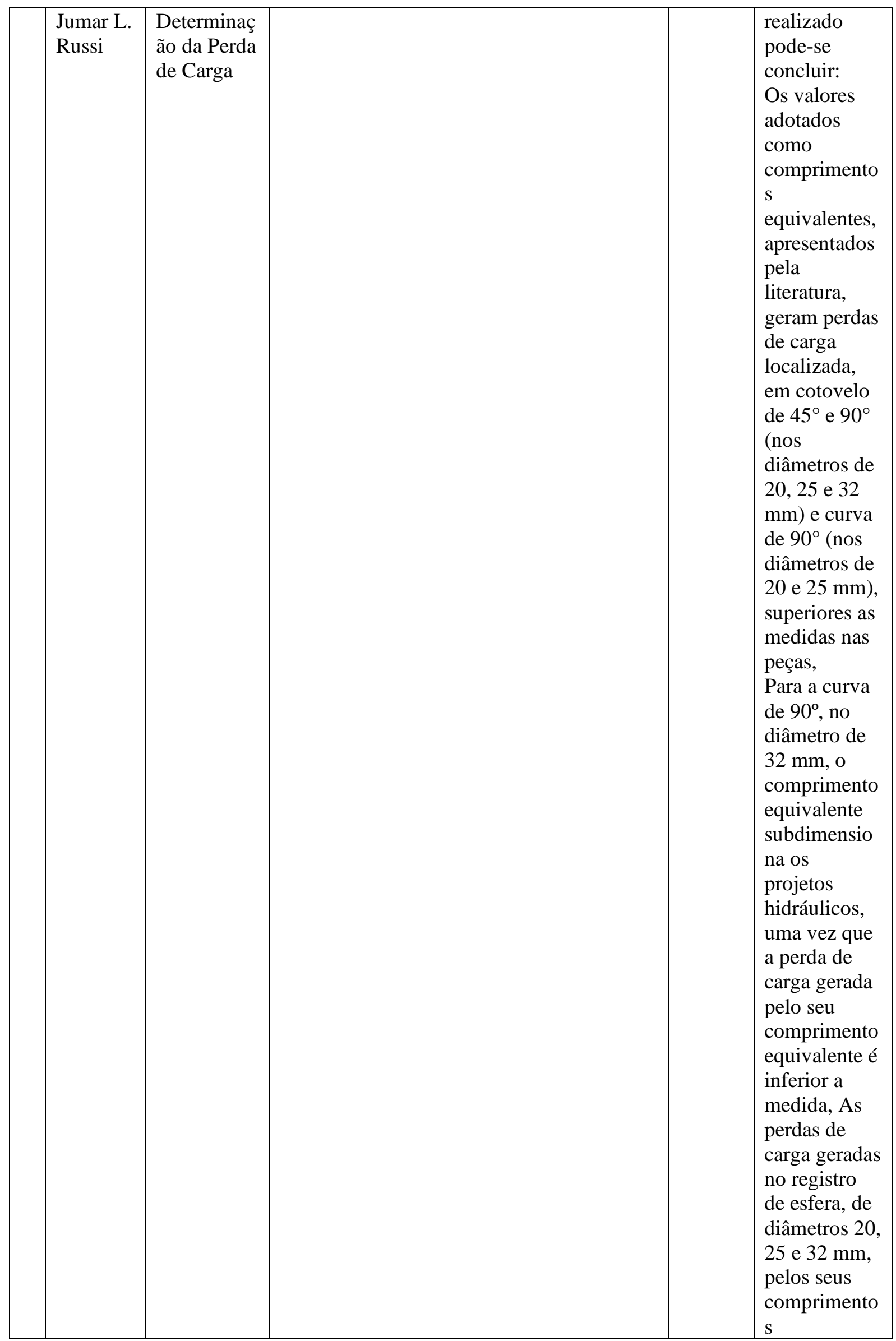




\begin{tabular}{|l|l|l|}
\hline & $\mid \begin{array}{l}\text { equivalentes } \\
\text { são inferiores } \\
\text { as medidas } \\
\text { na peça. } \\
\text { Portanto, nos } \\
\text { dimensionam } \\
\text { entos } \\
\text { hidráulicos } \\
\text { está-se } \\
\text { subestimand } \\
\text { o os mesmos, } \\
\text { não } \\
\text { utilizando } \\
\text { valores que } \\
\text { expressem } \\
\text { realmente a } \\
\text { perda de } \\
\text { carga } \\
\text { causada por } \\
\text { essas } \\
\text { singularidade } \\
\text { s, } \\
\text { acarretando } \\
\text { em erros nos } \\
\text { projetos de } \\
\text { instalações } \\
\text { hidráulicas, } \\
\text { podendo } \\
\text { assim } \\
\text { comprometer } \\
\text { a eficiência } \\
\text { das mesmas, } \\
\text { visto que } \\
\text { essas peças } \\
\text { são de uso } \\
\text { frequente, }\end{array}$ \\
\\
\\
\end{tabular}

Fonte: elaborada pelos autores.

O corpo textual foi analisado por meio da frequência de palavras, que originou a nuvem de palavras (Figura 1) criada na Plataforma online WordArt. Esta ferramenta agrupa e organiza graficamente as palavras-chave evidenciando-as as mais frequentes.

Figura 1 - Nuvem de palavras organizada na plataforma online do WordArt com base nas conclusões dos artigos contidos no Quadro 3. 


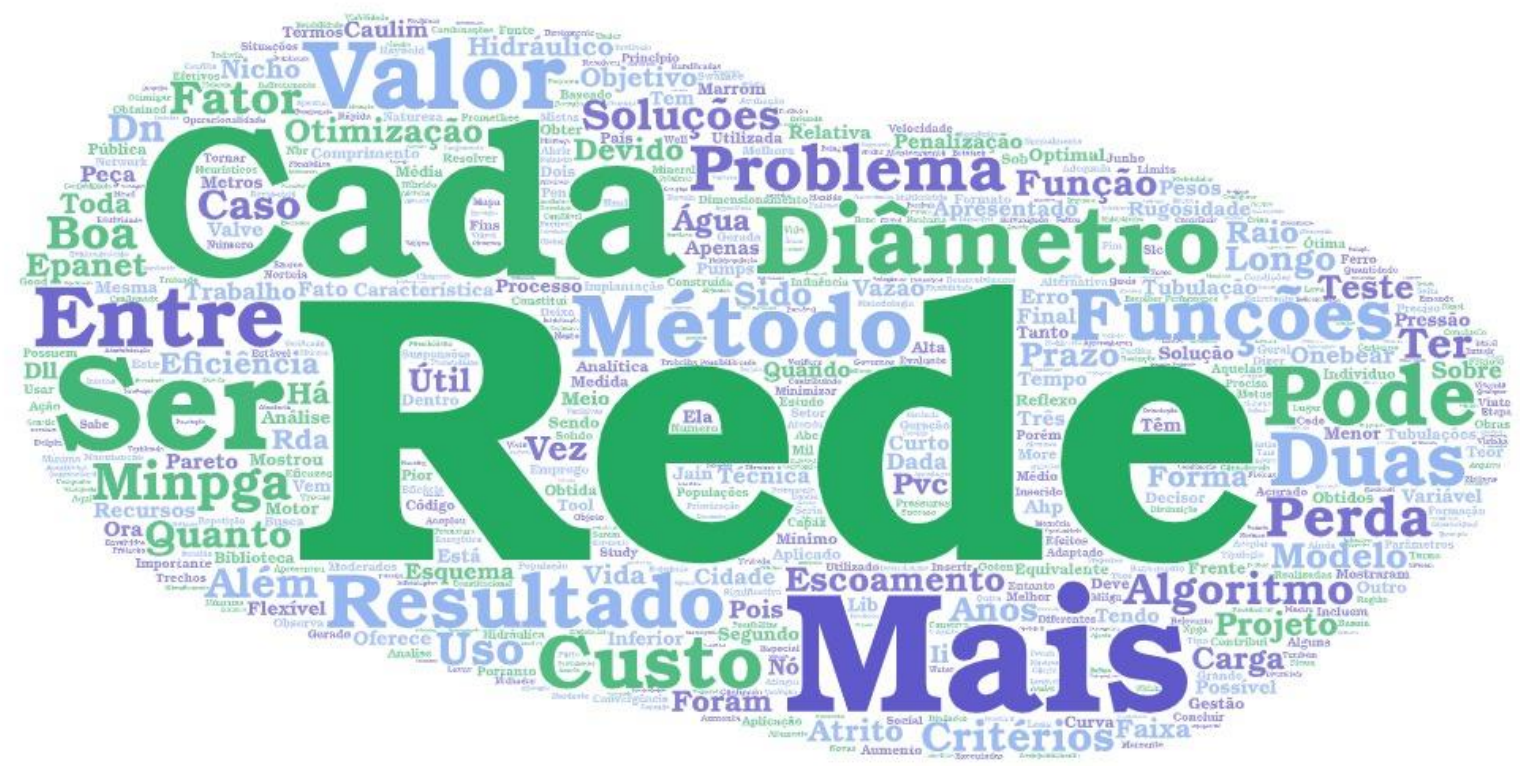

Fonte: elaborada pelos autores. 
Por meio da Figura 1, foi possível observar que as palavras em evidência na nuvem pertencem as categorias desenvolvidas a partir da análise de conteúdo. Todas as categorias derivam da sua frequência (Tabela 1), que diz respeito ao seu quadro referencial. Em consonância ao objetivo deste trabalho, optou-se por descrever as palavras que apresentaram frequência total no texto.

Tabela 1. Frequência das palavras presentes nos textos publicados nas Plataformas....

\begin{tabular}{l|c|l}
\hline \multicolumn{1}{c|}{ PALAVRAS } & FREQUÊNCIA & \multicolumn{1}{c}{ CATEGORIAS } \\
\hline Rede & 18 & Rede de abastecimento/distribuição \\
\hline Perda & 7 & Perda de carga \\
\hline Diâmetro & 10 & Diâmetro das tubulações \\
\hline Otimização & 6 & Otimização do projeto \\
\hline Método & 9 & Métodos para minimização de erros \\
\hline
\end{tabular}

Fonte: elaborada pelos autores.

\section{Discussões}

Atualmente, diversos trabalhos têm sido desenvolvidos na área de dimensionamento de redes de abastecimentos de águas, com o intuito de otimizar tanto o processo de dimensionamento quanto os cálculos de perdas de carga nas tubulações. Quanto maior a proporção de alcance da rede de distribuição, seu tempo de uso e a topografia a ser dimensionada, maior será a dificuldade de um dimensionamento reduzindo ao máximo o custo do investimento e otimizando o projeto a ponto de pouca ou nenhuma observação ser feita com relação a melhorias.
São muitos os fatores a serem analisados para a obtenção de um projeto onde é maximizado o custo/benefício da obra, para isso, o conhecimento dos fatores influenciadores na rede de distribuição é de suma importância. Em projetos relativamente extensos os erros tendem a ser superdimensionados ou subdimensionados, o que causam perdas de recursos, necessidade de mais mão de obra para refazer o serviço (quando possível ser realizado) e transtorno para todos os envolvidos.

Os fatores como: local de capitação, topografia do terreno, extensão do dimensionamento, pressão de captação e de fornecimento, vazão a ser fornecida, diâmetro das tubulações, rugosidade do 
material, tempo de uso, entre outros, são determinantes para a obtenção de um projeto otimizado.

Os trabalhos analisados usam de vários recursos como: programas computacionais, fórmulas disponibilizadas nas Normas Brasileiras e nas literaturas, experimento de campo com o propósito de facilitar o entendimento do dimensionamento de redes de abastecimento de águas e tornar o empreendimento mais seguro e rentável, oferecendo ao investidor um retorno confiável e duradouro.

Cada um dos trabalhos converge para uma importante observação que é o reconhecimento da necessidade de um projeto específico para cada situação. Porém, há elementos que permanecem presentes em todos os projetos, e especificamente são esses que conhecimento prévio do comportamento ajudará para uma melhor otimização da maioria dos projetos hidráulicos.

Elementos como; cano de PVC, de ferro, joelho de 45 e $90^{\circ}$, curvas, redutores, válvulas, entre outros mais, são diretamente influenciadores de perdas de carga, diminuição de velocidade de condução, desgaste do elemento usado no dimensionamento o que gerará uma diminuição da vida de uso do material. Cada um desses elementos possui um comprimento equivalente, que é entendido como a perda de carga localizada e distribuída nas tubulações. O estudo do comprimento equivalente (Leq) de cada um dos elementos que fará parte do dimensionamento da rede de distribuição será essencial para manter a pressão interna do fluído conforme o planejado, consequentemente a vazão e vida útil do material será próximo ao determinado no projeto.

Conforme concluíram, Soares; teles e Russi (2015), em seus estudos sobre a verificação do uso de comprimento equivalente em cálculos de perdas de cargas, foi que os valores que são disponibilizados pela literatura referente a elementos com perdas de cargas localizadas são superiores a medidas reais. Essa constatação foi aferida nas peças de curva de $90^{\circ}$ (diâmetros de 20 e $25 \mathrm{~mm}$ ) e em cotovelos de 45 e $90^{\circ}$ (diâmetros de 20, 25 e $32 \mathrm{~mm}$ ). Outra observação verificada foi que o comprimento equivalente determinado para o registro esfera, nos diâmetros de 20, 25 e $32 \mathrm{~mm}$, estava muito abaixo do real, ou seja, a perda de carga é muito maior do valor que estava se estimando.

Outra verificação muito importante feita por Kelner; Akutsu e Ribeiro (2016) quando estudado a relação da rugosidade nos tubos de PVC com o objetivo do 
dimensionamento das redes de distribuição de água, foi que quanto menor o diâmetro das tubulações maior será o desgaste com o passar dos anos. Esse desgaste ocorre devido a velocidade do fluido ser muito maior em diâmetros menores.

Por esses pontuais fatores observase que o dimensionamento de uma rede de distribuição, com vista na otimização completa do projeto é algo muito complexo, e por isso, o conhecimento de programas computacionais é de suma importância para diminuição da complexidade e para reduzir possíveis erros quando dimensionado de maneira manual.

Dentre os artigos analisados um algoritmo chamado de EPANET é o mais usual para facilitar o dimensionamento. Segundo o trabalho de Takeo et al., (2020) o programa apresentou um desempenho satisfatório, sendo capaz de estabelecer as pressões dentro do limite estudado e ainda indicando a quantidade de bombas e válvulas a serem empregadas.

Claro que um projeto de dimensionamento, como dito anteriormente, quanto maior a dimensão de

\section{CONCLUSÕES}

Em suma, o presente artigo apresenta os diversos fatores que influenciam as perdas de cargas existentes nas redes de distribuição de água, esses alcance desejado, maior será sua complexidade e consequentemente será impossível resolver todos os problemas da rede. Com isso, verifica-se que existe a possibilidade de erros de projeto, o que ocasionara possíveis rompimentos de tubulações e consequente perdas de água, danos ao meio ambiente e transtorno para a população próxima. Levando isso em consideração, existem métodos para analisar locais específicos que geraria esses possíveis erros, sendo assim chamados de critérios de avaliação, onde é determinado qual local a ser executado deverá receber maior atenção. Um dos métodos que tem tido preferência é o PROMETHEE (Preference Ranking Organization Method for Envrichment Evaluation), como o próprio nome revela, o método estabelece um ranking de critérios dando ao executador a possibilidade de minimizar os possíveis erros, garantindo assim a otimização do projeto. Segundo Costa; Virginio e Texeira (2010) esse método se mantem satisfatório tanto para projetos de pequeno quanto de grandes portes.

trazem consigo insatisfação à população, impactos ambientais e custos elevados para executar e/ou fazer manutenções.

Contudo, a partir dos resultados obtidos e visando minimizar as perdas de 
cargas, faz-se necessário ampliar os estudos

para melhoria dos projetos hidrossanitários e recursos para execução, desde a captação até a distribuição.

\section{REFERÊNCIAS}

Brasil. Fundação Nacional de Saúde. Manual de Orientações Funasa. - Brasília: Funasa, 2017.

KELLNER, E.; AKUTSU, J.; REIS, L. F. R. Avaliação da rugosidade relativa dos tubos de PVC com vistas ao dimensionamento das redes de distribuição de água. Engenharia Sanitária e

Ambiental, v. 21, n. 2, p. 347-355, 2016.

MANZI, D. et al. Dimensionamento ótimo de redes de distribuição de água com uso de métodos de otimização inspirados na natureza. Revista DAE, v. 66, n. 212, p. 16-31, 2018.

MELO BRENTAN, B. et al. Dimensionamento de redes de distribuição de água por meio de análise multicriterial. Revista DAE, v. 221, n. 68, p. 118-130, 2019.

MORAIS, D. C.; CAVALCANTE, C. A. V.; DE ALMEIDA, A. T. Priorização de áreas de controle de perdas em redes de distribuição de água. Pesquisa

Operacional, v. 30, n. 1, p. 15-32, 2010.
Logo, concluímos que para otimizar os projetos é recomendado usar programas computacionais com intuito de reduzir ao máximo os possíveis erros de projetos de redes de distribuição.

NOVARINI, B. et al. Gerenciamento de pressão ideal em redes de distribuição de água por meio da criação de área distrital medida com base em aprendizado de máquina. Revista Brasileira de Recursos Hídricos, v. 24, p. 1-11, 2019.

PINNTO, M. R. et al. Dimensionamento econômico otimizado de redes de distribuição de água considerando custos de manutenção. Engenharia Sanitária e Ambiental, v. 22, n. 1, p. 145-153, 2017.

SILVA, A.; DA SILVA, F.; DA SILVA, A. Proposal of optimal operation strategy applied to water distribution network with statistical approach. Revista Ambiente e Água, (2020), 15(2) Disponível em: Proposal of optimal operation strategy applied to water distribution network with statistical approach (scielo.br).

SILVA, F. D. B.; O. O Sistema De Abastecimento D' Água Da Cidade De Santa Rita - Pb. 2016. SOARES, F.; TELES, G.; RUSSI, J. Aferição dos Valores dos Comprimentos Equivalentes Utilizados na Determinação da Perda de Carga. Revista de Ciencia y Tecnología, n. 24, p. 16-21, 2015. 
